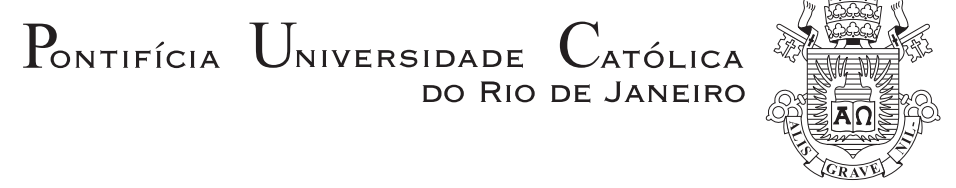

André Luis Ferreira Beltrão

Práticas pedagógicas no ensino de Design: experimentando abordagens significativas

Tese de Doutorado

Tese apresentada ao Programa de Pós-graduação em Design da PUC-Rio como requisito parcial para obtenção do grau de Doutor em Design.

Orientador: Prof. Rita Maria de Souza Couto Co-orientador: Prof. Flavia Nizia da Fonseca Ribeiro

Rio de janeiro, Março de 2021 


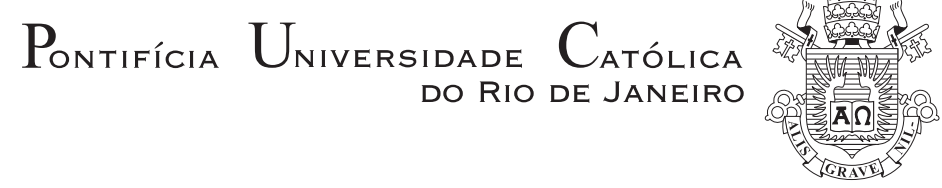

André Luis Ferreira Beltrão

\title{
Práticas pedagógicas no ensino de Design: experimentando abordagens significativas
}

\begin{abstract}
Tese apresentada como requisito parcial para obtenção do grau de Doutor pelo Programa de Pós-graduação em Design da PUC-Rio. Aprovada pela Comissão Examinadora abaixo assinada.
\end{abstract}

Prof. Rita Maria de Souza Couto Orientador Departamento de Artes e Design

Prof. Flavia Nizia da Fonseca Ribeiro

Co-orientador Departamento de Artes e Design

Prof. Luiza Novaes Departamento de Artes e Design

Prof. Maria Apparecida Campos Mamede Neves Departamento de Artes e Design

Prof. Ana Amélia Erthal Escola Superior de Propaganda e Marketing

Prof. Eliana de Lemos Formiga Escola Superior de Propaganda e Marketing

Prof. Monah Winograd Coordenadora Setorial do Centro de Teologia e Ciências Humanas - PUC-Rio

Rio de janeiro, 12 de março de 2021 
Todos os direitos reservados. A reprodução, total ou parcial do trabalho, é proibida sem autorização da universidade, do autor e do orientador.

\section{André Luis Ferreira Beltrão}

Graduou-se em Desenho Industrial, habilitação Comunicação Visual, pela PUC-Rio em 1995. Especialista em Marketing pelo IBMEC-RJ em 2004. Mestre em Design pela PUC-Rio em 2017. É professor dos cursos de Design da PUC-Rio e da ESPM-RJ. Foi sócio-diretor do Studio Creamcrackers, escritório de Design, de 1998 a 2019.

Ficha Catalográfica

Beltrão, André Luis Ferreira

Práticas pedagógicas no ensino de Design : experimentando abordagens significativas / André Luis Ferreira Beltrão ; orientador: Rita Maria de Souza Couto ; co-orientador: Flavia Nizia da Fonseca Ribeiro. $-2021$.

151 f. : il. color. ; $30 \mathrm{~cm}$

Tese (doutorado)-Pontifícia Universidade Católica do Rio de Janeiro, Departamento de Artes e Design, 2021.

Inclui bibliografia

1. Artes e Design - Teses. 2. Aprendizagem significativa. 3. Ensino. 4. Design. 5. Metodologias ativas. 6. Práticas pedagógicas. I. Couto, Rita Maria de Souza. II. Ribeiro, Flavia Nizia da Fonseca. III. Pontifícia Universidade Católica do Rio de Janeiro. Departamento de Artes e Design. IV. Título. 
Ao Tito e ao Miguel, pelo tempo ausente, 


\section{Agradecimentos}

A todos os professores e colegas que foram tão importantes em minha caminhada, especialmente a Eduardo Ariel, Manolita Corrêa, Luciano Tardin, Leonardo Marques, Nathalia Cavalcante, Celso Wilmer, Eliana Formiga, Rita Couto, Flavia Nizia, Joy Till, Roberta Portas, Izabel Oliveira, Guto lins, Luiz Ludwig, Amador Perez, Vera Damazio e Fernando Borges.

Aos colegas professores e designers, e aos alunos que participaram da pesquisa e das aulas ao longo desses anos, sobretudo a Rafael Mesquita, Julia Kürten e Maria Eduarda Coelho, que colaboraram em partes importantes deste trabalho e agradeço a todos que participaram do incrível grupo do Estudio de Desenho da ESPM, que desenhou e coloriu difíceis semanas.

A Lesley Ann Noel e a Maria de Mater O’Neill pela disponibilidade e empolgação na concepção do nosso experimento internacional, mesmo não tendo sido realizado.

À colaboração dos colegas e amigos da marinha do Brasil, capitão de mar e guerra Emerson Serafim, comandante do Colégio Naval e do capitão de mar e guerra Hélio Branco, comandante do centro de trinamento de submarinistas da ilha de Mocanguê.

À PUC-Rio e à ESPM, por terem viabilizado esta tese de doutorado.

Agradeço enfim à minha família, como sempre, pelo suporte, paciência e resiliência, Aline Haluch, Tito e Miguel.

A meus pais e aos meus ancestrais, que se combinaram até que eu nascesse.

O presente trabalho foi realizado com apoio da Coordenação de Aperfeiçoamento de Pessoal de Nível Superior - Brasil (CAPES) - Código de Financiamento 001 


\section{Resumo}

Beltrão, André Luis Ferreira; Couto, Rita Maria de Souza (Orientadora). Práticas pedagógicas no ensino de Design: experimentando abordagens significativas. Rio de Janeiro, 2021. 151 p. Tese de Doutorado - Departamento de Artes e Design, Pontifícia Universidade Católica do Rio de Janeiro.

Esta tese tem como objetivo a proposição e análise de práticas pedagógicas relacionadas ao aprendizado significativo em disciplinas de Design Gráfico.

Considerando que o aprendizado significativo ocorre quando o estudante aprende algo que tem significado pessoal, conectando algo novo a suas experiências e conhecimentos prévios, mas que em cada sala de aula há estudantes que aprendem de forma diferente e têm diferentes universos dentro de si, foram criados dois experimentos abertos de aprendizagem significativa.

Desenvolveu-se também um instrumento de avaliação e análise que pode ser aplicado ao planejamento de aulas significativas em quaisquer disciplinas.

Nas considerações finais foram propostos outros experimentos como sugestões de atividades pedagógicas orientadas à investigação do tema, que não foram testadas em campo ainda mas poderão ser livremente desenvolvidas como extensão ou retomada da pesquisa.

\section{Palavras-chave}

Aprendizagem significativa; ensino; Design; metodologias ativas; práticas pedagógicas; experimentação; exercícios; motivação; desenho. 


\section{Abstract}

Beltrão, André Luis Ferreira; Couto, Rita Maria de Souza (Advisor). Pedagogical practices in teaching design: experiencing significant approaches. Rio de Janeiro, 2021. 151 p. Tese de Doutorado - Departamento de Artes e Design, Pontifícia Universidade Católica do Rio de Janeiro.

This thesis aims at proposing and analyzing pedagogical practices related to significant learning in Graphic Design disciplines.

Considering that significant learning occurs when the student learns something that has personal meaning, connecting something new to his previous experience and knowledge, and that in each classroom students have different learning preferences and patterns, holding completely different universes within themselves, two open experiments of significant learning have been set forth.

An evaluation and analysis tool that may be applied to the planning of significant classes in any subject has also been developed.

In the final considerations, other experiments were proposed as suggestions for pedagogical activities oriented to the investigation of the theme, which have not been tested in the field yet but can be freely developed as an extension or resumption of the research.

\section{Keywords}

Significant learning; teaching; Design; active methodologies; pedagogical practices; experimentation; exercises; motivation; drawing. 


\section{Sumário}

Parte1 - Textos introdutórios

\begin{tabular}{ll}
\hline 1 - Introdução & 10 \\
Contextualização & 10 \\
Problema de pesquisa / questão norteadora & 12 \\
Objeto de estudo & 13 \\
Objetivo geral & 13 \\
Objetivos específicos & 13 \\
Premissas & 14 \\
Hipótese & 15 \\
Relevância educacional & 15 \\
Relevância social & 15 \\
Relevância acadêmica & 15 \\
Relevância pessoal & 15 \\
Revisão da literatura & 18 \\
1.1 - Visão geral do método & 16 \\
1.11.1 - O Desenho da pesquisa & 16 \\
1.2 - Estrutura da tese & 17
\end{tabular}

Parte 2 - Método

2.1. Aprendizagem significativa e estilos de aprendizagem 20

2.2. Metodologias ativas de ensino-aprendizagem 22

2.3. Desenvolvimento do instrumento de avaliação e análise criado a partir da taxonomia de Fink 23

2.4. Desenho da pesquisa 31

2.2.1. Atores da Pesquisa 31

2.5. Procedimentos de realização do projeto 32

2.6. Pesquisa-intervenção 34

2.7. Instrumentos de pesquisa 35

Parte 3 - O Campo: investigação, reflexão teórica e análise

3 - Cidade Submarina: o pensamento divergente e o estranhamento como fios condutores para uma heterotopia criativa $\quad 39$

3.1. Briefings Randômicos 41

3.2. A disciplina adotada: Projeto II 43

3.3. A Cidade Submarina 44

3.4. Relatório diário 2018.1 - Diário de bordo e reflexões $\quad 54$

3.5. Entrevistas com alunos $\quad 72$ 
3.6. Entrevistas com professores $\quad 75$

3.7. Testes de aplicação no ensino fundamental
e no ensino médio

4 - Estudio livre de Desenho: um estudo de autoaprendizagem significativa inspirado em grupos operativos

4.1. A formação do Estudio Livre de Desenho 85

4.2. Sobre Grupos operativos 89

4.3. Estudio de Desenho 2018.2 - observação e reflexões 91

4.4. Estudio de Desenho 2019.1 - observação e reflexões $\quad 96$

4.5. Estúdio de Desenho no Exílio 101

4.6. Reflexão na Ação 108

5 - Proposição de outras práticas pedagógicas a partir da aprendizagem significativa em Design 111

5.1. Chaveiro de significação de atividades 111

5.2. Disciplina eletiva de representação bidimensional $\quad 117$

5.3. Experimento colaborativo internacional Cidade
Submarina 3.0

5.4. Disciplina eletiva colaborativa Estudio Livre
de Desenho em modelo misto (presencial e online)
121

6 - Considerações finais: interpretação e análise dos achados da pesquisa 123

Considerações finais e desdobramentos 123

\begin{tabular}{ll}
7 -Referências bibliográficas & 129 \\
\hline
\end{tabular}

\begin{tabular}{lr}
8 - Apêndices & 133 \\
\hline
\end{tabular} 


\section{Introdução}

No mestrado pesquisei a aplicação das Metodologias Ativas no ensino de Design Gráfico ${ }^{1}$. Tais metodologias são centradas no estudante, onde ele toma parte ativa na definição dos conteúdos e na montagem das aulas, enquanto o professor desempenha um papel de intermediador ou facilitador do acesso a esses conteúdos. As aulas têm menor peso teórico e maior peso na construção coletiva do conhecimento, que é desenvolvido em profundidade. As aulas precisam ser pensadas estrategicamente, utilizando atividades pré-aula, atividades de aula e atividades pós-aula, que servem para preparar os alunos introduzindo, desenvolvendo e amarrando os conceitos.

Originalmente formuladas para disciplinas e cursos de outras áreas de conhecimento, sobretudo cursos de Administração e Exatas, ao longo da pesquisa percebi que tais Metodologias Ativas muito se aproximavam das metodologias de projeto de Design, e que nas disciplinas de Design Gráfico não operavam sozinhas transformações relevantes.

Os resultados mais expressivos, sobretudo relacionados ao engajamento dos alunos e à vontade de aprender de forma ativa, surgiam quando algum aspecto das aulas ou da formulação dos enunciados de trabalhos e projetos era mais significativo para eles. Estudei a aprendizagem significativa de Ausubel (1963) e descobri a Taxonomia da aprendizagem significativa de Lee Dee Fink².

Segundo Fink (2007), a aprendizagem significativa está na interseção de seis categorias de aprendizagem: aprender a aprender, conceitos-chave, aplicabilidade, integração, auto-realização e importar-se. Formulei alguns enunciados baseados na aprendizagem significativa, buscando atender a todas as categorias de aprendizagem descritas por Fink (2007), que trouxeram resultados muito bons, com trabalhos muito mais completos, mais criativos, que superaram minhas expectativas.

Em alguns casos, porém, encontrei ainda resistência e não consegui motivar positivamente alguns estudantes a atingirem os resultados esperados. Para esses alunos, as propostas não foram significativas, foram desinteressantes. Segundo Dewey (1980), o interesse não pode ser simplesmente criado, mas surge naturalmente quando se promovem condições propícias.

1 Estratégias pedagógicas no ensino de Design: por uma Metodologia Ativa.

2 Vide capitulo 2.1 - aprendizagem significativa e estilos de aprendizagem. 
Considerando o conceito de que os problemas de Design são problemas complexos, pois estão relacionados a pessoas e a aspectos culturais e tecnológicos (Morin, 2014), cada projeto de Design pode ser visto como uma mudança no sistema em que se insere, ao invés de uma simples relação de problema/solução (Findeli, 2001).

Como encontrar tais condições é uma das questões norteadoras que se apresenta. Em um projeto de Design, segundo Findeli (2001), partimos de um sistema inicial que envolve todas as variáveis presentes no briefing, o designer, o cliente ou usuários, o meio e a situação-problema. O projeto de design transforma o sistema, e o designer, enquanto aprende e cria, também é modificado.

A modificação que ocorre nos estudantes no processo projetual é o aprendizado significativo descrito por Ausubel (1963), onde cada experiência de aprendizado torna-se a base para o desenvolvimento incremental do conhecimento, e o resultado pode ser associado ao aprendizado em diferentes categorias da taxonomia de Fink (2007).

Segundo Dewey (1980), porém, é no sistema inicial que se encontra a variável motivação, interna aos estudantes. Como prospectar essa motivação intrínseca, como criar enunciados que se moldem ou se encaixem no maior número possível de estudantes para deixar os problemas complexos mais significativos, como motivar para a ação? A ação alimenta a reflexão, que alimenta a ação, que alimenta a reflexão, e essa é a base do sistema incremental do aprendizado significativo.

Schön (2000) fala sobre essa reflexão num processo de tentativa e erro, em que cada tentativa prepara o terreno para uma tentativa posterior aprimorada, e também sobre a reflexão-na-ação como um refletir enquanto se está fazendo algo, durante a ação, quando se pode interferir em situações ainda em desenvolvimento. Mas para essa reflexão ter lugar, entretanto, é essencial a ação.

Tornar os problemas mais significativos para incentivar a ação refere-se a um processo de significação, ou ressignificação de um problema. Em semiótica, o significado é percebido a partir da associação entre o significante e o referente. Se considerarmos o referente como os conhecimentos e experiências prévias dos estudantes, que não nos é dado conhecer ${ }^{3}$, talvez os briefings precisem atuar como significantes provocativos para sempre gerarem algum significado.

Imaginei, portanto, que seria possível promover o aprendizado significativo de modo mais abrangente utilizando, além das categorias do aprendizado significativo de Fink (2007), a contextualização dos problemas complexos de modo a

3 Tal desinteresse no estado inicial pode se relacionar ao tema, que pode gerar a não identificação, ou mesmo repulsa. Pode se relacionar às condições que o aluno terá para executar as tarefas, a quanto precisará gastar, a aspectos éticos, a distâncias, inúmeros fatores. 
permitir alguma flexibilização que se adeque aos aspectos pessoais da vida dos estudantes, gerando significação para eles.

Essa foi a base para a concepção dos experimentos de campo da pesquisa, apresentados nos capítulos 3 e 4, e de outras proposições pedagógicas apresentadas no capítulo 5.

Segundo Ausubel (1963), os conhecimentos prévios e os adquiridos pelos estudantes se interrelacionam em cadeias hierárquicas, e essa estrutura hierárquica nos remete à taxonomia de Bloom, muito utilizada no planejamento de disciplinas.

Os planos de ensino-aprendizagem (PEAs), elaborados a partir da taxonomia de Bloom, inserem-se no conceito de Ensino por Competência, onde os educadores buscam definir que competências (o saber), habilidades (o saber fazer) e atitudes (o querer ser, fazer e transformar) os estudantes devem ter atingido ao completar cada disciplina. A partir dessas definições, e do conhecimento do que o estudante já aprendeu em disciplinas anteriores, são definidos objetivos de aprendizagem para as disciplinas, a partir dos quais são elaborados os planos de aula.

A taxonomia de Bloom definie categorias de aprendizagem divididas hierarquicamente - lembrar, entender, aplicar, analisar, avaliar e criar, cada uma agrupando conhecimentos factuais, conceituais, metodológicos e metacognitivos - e pressupõe que o estudante só será capaz plenamente de aprender algo se tiver experienciado as etapas anteriores.

No mestrado estudei a elaboração e execução das aulas segundo as metodologias ativas e um dos achados da pesquisa foi a taxonomia das categorias de aprendizagem significativa de Fink (2007).

A taxonomia da aprendizagem significativa de Fink atuou no planejamento das aulas, enquanto a tradicional taxonomia cognitiva dos objetivos educacionais de Benjamin Bloom tinha atuado no planejamento dos objetivos de aprendizagem, complementando-se.

No entanto, chegou-se à conclusão que tais metodologias são muito efetivas, mas dependem da motivação dos estudantes, de encontrar-se aquele ponto inicial a que Dewey e Ausubel se referiam, de o estudante entrar em ação.

Este trabalho foi uma pesquisa-intervenção em disciplinas de Design Gráfico, unindo as taxonomias de Bloom e de Fink, que muitas vezes são percebidas como taxonomias em oposição, investigando meios de prospectar a motivação inicial dos estudantes, criando estratégias de ensino que favorecessem o cumprimento dos objetivos de ensino-aprendizagem.

Desse modo, meu problema de pesquisa foi o seguinte: práticas pedagógicas no ensino de Design, tendo por fio condutor experimentos com abordagens 
significativas, podem se tornar significativas para os estudantes, motivando-os positivamente a se engajar em um processo pessoal de aprendizado em disciplinas de Design Gráfico?

Como o campo de pesquisa foi a sala de aula, o objeto de estudo desta pesquisa foi o planejamento de aulas e formulação de exercícios projetuais e o objetivo geral da investigação foi propor e analisar práticas pedagógicas relacionadas ao aprendizado significativo em disciplinas de Design Gráfico.

Quando planejei a metodologia da pesquisa, defini alguns objetivos específicos a atingir no percurso:

A - Percebi que precisaria identificar fontes teóricas relacionadas ao ensino do Design Gráfico que pudessem fundamentar o processo de experimentações e exercícios criativos, enriquecendo e ampliando as discussões sobre as experiências que seriam realizadas.

B - A partir disso, criar experimentos ou exercícios que permitissem mapear interesses, habilidades e competências dos alunos.

C - Partindo das Metodologias Ativas, considerando o aprendizado significativo, propor enunciados abertos de exercícios projetuais, onde cada estudante pudesse desenvolver os caminhos de experimentação que escolhesse e o professor atuasse como um tutor, um facilitador dos processos.

D - Desenvolver o planejamento de aulas de um exercício projetual de Design Gráfico formulado segundo a taxonomia do aprendizado significativo de Fink (2007), tendo por laboratório a sala de aula, inserindo-o em uma disciplina de projeto, que permitisse o aprendizado significativo também de conteúdos teóricos, associados ao exercício projetual proposto.

E - Partindo dos objetivos de aprendizagem definidos a partir da taxonomia de Bloom nos programas de ensino-aprendizagem de disciplinas de Design Gráfico, propor estratégias para o planejamento de aulas segundo a taxonomia do aprendizado significativo de Fink (2007). 
Cada objetivo específico está relacionado a um capítulo da tese, segundo procedimentos metodológicos descritos no capítulo 2 .

\begin{tabular}{|c|c|c|}
\hline Objetivo específico & procedimento & $\begin{array}{l}\text { capítulos } \\
\text { relacionados }\end{array}$ \\
\hline $\mathrm{A}$ & . revisão de literatura . . . . . . . & $2,3,4$ e 5 \\
\hline $\mathrm{B}$ & $\begin{array}{l}\text { entrevista, experimentação . } \\
\text { e registro, autoavaliação }\end{array}$ & \\
\hline $\mathrm{C}$ & $\begin{array}{l}\text { experimentação e registro, . } \\
\text { entrevista, autoavaliação }\end{array}$ & 4 \\
\hline $\mathrm{D}$ & $\begin{array}{l}\text { pesquisa-intervenção com. . } \\
\text { registro em diário de bordo, } \\
\text { questionário, entrevista, } \\
\text { registro fotográfico } \\
\text { e autoavaliação }\end{array}$ & 3 \\
\hline $\mathrm{F}$ & $\begin{array}{l}\text {. análise e proposição } . . . \\
\text { de modelo }\end{array}$ & 5 \\
\hline
\end{tabular}

Como esta pesquisa se desenvolveu a partir dos desdobramentos propostos na dissertação "Estratégias pedagógicas no ensino de Design: por uma Metodologia Ativa "4, para o planejamento da pesquisa foram adotados dois conjuntos de premissas dali oriundos.

O primeiro conjunto traz premissas relacionadas a metodologias ativas e aprendizagem significativa:

- Metodologias ativas são capazes de ativar o aprendizado dos estudantes desde que haja motivação para despertar seu engajamento.

- Quando o estudante não se engaja com o que está sendo ensinado ou trabalhado nas disciplinas, ele não tem postura ativa, e portanto não entra em ação.

- Quando não há motivação para aprender, o estudante não encontra significado na experiência de aprendizagem e não ocorre nele o processo de aprendizagem significativa.

O segundo conjunto tem premissas relacionadas à taxonomia da aprendizagem significativa (Fink, 2007):

- Quando alguma das categorias da aprendizagem significativa vai ao encontro das motivações internas dos estudantes, a aprendizagem significativa ocorre.

4 Beltrão (2017) - Pesquisa de mestrado sobre metodologias ativas. 
- Disciplinas formuladas para atingirem diferentes categorias da aprendizagem significativa têm grande participação e engajamento dos estudantes.

A partir desses conjuntos de premissas, do contexto e da questão norteadora, defini como hipótese:

A formulação de problemas complexos e abertos, baseados na taxonomia do aprendizado significativo de Fink $(2007)^{5}$ e capazes de se relacionar de forma relevante com as realidades diversas dos alunos pode potencializar o aprendizado das disciplinas de Design Gráfico.

A relevância educacional da pesquisa está na busca da ativação dos estudantes para o processo de aprendizagem. O estudo da formulação dos problemas de projeto, considerando serem mais situações de projeto que problemas, e o planejamento de aulas aditivado por elementos de metodologias ativas calcados nas categorias do aprendizado significativos de Fink (2007) podem gerar maior pré-disposição ao aprendizado e maior envolvimento dos alunos com os conteúdos-chave das disciplinas.

A relevância social está na conexão do estudante com seu processo de aprendizagem para a vida. Contribuindo para um aprendizado mais significativo, através da aproximação das situações de projeto da vida e das expectativas de cada um, à medida que os estudantes adquirirem conhecimentos e se modificarem, perceberão que podem ser agentes modificadores do mundo. Uma das categorias do aprendizado significativo de Fink (2007) refere-se a se importar, e se refere exatamente a essas mudanças interiores de pontos de vista, ao desenvolvimento da ética e da consciência do papel que cada um pode ter no mundo.

A relevância acadêmica relaciona-se aos desdobramentos. A pesquisa registrou experimentações relacionadas ao aprendizado significativo, identificando aspectos e processos que geraram adesão e predisposição dos alunos ao aprendizado, contribuindo assim para melhor desempenho acadêmico, atuando como ponto de partida para a formulação de estratégias de ensino.

Tal mapeamento e tais conclusões poderão ser retomados, revisitados e expandidos em pesquisas futuras de outras áreas de ensino, atuando de forma interdisciplinar como ponto de partida para a formulação de outras estratégias de ensino.

A relevância pessoal esteve no prazer de fazer. Como professor, sempre busquei criar propostas desafiadoras e interessantes para aplicação em sala de aula, sempre busquei tornar claros os conceitos que explico e conectar cada conhecimento a outros ensinados antes ou ao mundo real, para tornar os temas mais interessantes. Estudar práticas pedagógicas foi importante para sistematizar as práticas pessoais, pesquisei um tema totalmente aplicável e o processo foi gratificante e acima de tudo, divertido. 


\section{1}

\section{Visão Geral do Método}

A pesquisa teve uma abordagem qualitativa, desenvolvendo-se como uma pesquisa-intervenção, em um estudo exploratório no qual o pesquisador foi participante.

Segue quadro-resumo das escolhas metodológicas para essa tese:

\begin{tabular}{ll} 
Natureza & Aplicada \\
\hline Problema & Qualitativa \\
\hline Objetivo & Exploratória \\
\hline Procedimentos & $\begin{array}{l}\text { Revisão bibliográfica, } \\
\text { Pesquisa-intervenção em disciplina de Design Gráfico }\end{array}$ \\
\hline Técnicas & Entrevistas \\
& Autoavaliações de estudantes \\
& Experimentos/ dinâmicas exploratórias em Design Gráfico \\
& Experiências projetuais colaborativas
\end{tabular}

\subsection{1 - O Desenho da pesquisa}

O desenho completo da pesquisa está apresentado no capítulo 2.4 desta tese. Essencialmente, a pesquisa envolveu os seguintes passos:

- Aprimoramento do uso da Taxonomia do Aprendizado Significativo de Fink (2007) como instrumento de planejamento de aulas e de auto-avaliação.

- Experimento de criatividade (briefing randômico), realizado por mim em disciplina de publicidade na ESPM-RJ.

- Realização de experiências projetuais e de criatividade colaborativas em diferentes instituições de ensino, para investigar variáveis como o papel do professor e o contexto cultural, que foram documentados e analisados.

- Realização de autoavaliações entre os estudantes, por questionário e entrevista, segundo suas percepções de aprendizagem em instrumento próprio inspirado em Fink (2007).

- Pesquisa-intervenção: planejamento e realização do exercício projetual Cidade Submarina, inserido em disciplina de projeto de Design Gráfico lecionada por mim, onde foram testadas práticas baseadas no aprendizado significativo de Fink. O segundo semestre de aplicação foi replanejado e ajustado com base nos resultados do primeiro e registrado em diário de pesquisa aula a aula, suportado por questionários e entrevistas com alunos. 
- Análise dos resultados obtidos nos experimentos, do diário de bordo, das entrevistas e autoavaliações nas disciplinas de Design Gráfico pesquisadas, embasada por bibliografia de Design e áreas afins.

- Pesquisa-ação: planejamento e acompanhamento do experimento de aprendizagem colaborativa Estúdio Livre de Desenho ESPM, inspirado nos Grupos Operativos de Pichón-Rivére (1986), onde foram investigados processos de autoaprendizagem e aprendizado em grupos, observados à luz de Fink (2007). Esse experimento teve inicialmente aplicações presenciais e depois dois semestres de operação virtual, durante o isolamento social imposto pela pandemia do Covid-19, ocasião em que foi expandido para todas as unidades da ESPM (Rio, São Paulo e Porto Alegre).

- Proposição de estratégias pedagógicas.

\section{2 \\ Estrutura da tese}

\section{Parte 1- textos introdutórios}

\section{Capítulo 1: introdução}

Este capítulo apresenta o contexto da pesquisa, caracterizando o objeto de estudo e estabelecendo os objetivos geral e específicos e propondo as questões norteadoras e hipótese. Traz também o resumo do método, que é mais amplamente abordado no capítulo 2 .

Parte 2 - método (cap.2)

\section{Capítulo 2: método}

O capítulo revisita os conceitos de aprendizagem significativa, estilos de aprendizagem e metodologias ativas. Relata o desenvolvimento do instrumento de autoavaliação e análise criado a partir da Taxonomia de Fink (2007). Descreve, em seguida, a metodologia de trabalho, como se deu a pesquisa-intervenção em seus métodos, registros e controles e como foram desenvolvidos e planejados os demais procedimentos metodológicos.

Parte 3 - O Campo: investigação, reflexão teórica e análise (cap.3, 4 e 5)

Capítulo 3: Cidade Submarina: o pensamento divergente e o estranhamento como fios condutores para uma heterotopia criativa

Registro e análise da pesquisa-intervenção.

Exercício projetual inserido em uma disciplina de projeto de Design gráfico, que investigou a motivação, a criatividade e que permitiu o aprendizado significativo também de conteúdos teóricos, associados ao exercício projetual proposto. 
Registro em diário de bordo, questionário de autoavaliação aplicado aos estudantes, entrevistas não estruturadas com estudantes e professores participantes como marcos da pesquisa-ação.

Capítulo 4: Estúdio livre de Desenho: um estudo de autoaprendizagem significativa inspirado em grupos operativos

O capítulo apresenta um estudo desenvolvido a partir da teoria dos grupos operativos, realizado no Estúdio de Desenho, por mim fundado na ESPM para fins dessa pesquisa, objetivando observar o envolvimento e motivação dos estudantes no desenvolvimento de trabalhos pessoais em um ambiente de ensino colaborativo não sujeito a avaliações formais. Foram feitas análises a partir de Fink e entrevistas não estruturadas com os estudantes.

O capítulo registra também uma variante do campo originada pela migração ao ambiente digital devido ao confinamento imposto pela pandemia do Covid-19.

\section{Capítulo 5: Proposição de outras práticas pedagógicas a partir} da aprendizagem significativa em Design

O capítulo apresenta quatro sugestões de experimentos elaboradas a partir dos achados de pesquisa da Cidade Submarina e do Estúdio Livre de Desenho.

\section{Capítulo 6: Considerações finais: interpretação e análise dos achados da pesquisa \\ Análise dos achados da pesquisa, considerações e desdobramentos.}

Parte 4 - bibliografia e anexos 


\section{2 \\ Método}

Este capítulo revisita as metodologias ativas de ensino-aprendizagem, objeto de estudo da dissertação de mestrado do autor, assim como o que é aprendizagem significativa e a Taxonomia da Aprendizagem Significativa de Lee Dee Fink. Em seguida, apresenta o desenvolvimento de um instrumento de avaliação e análise criado a partir de Fink (2007). O instrumento foi utilizado na análise do experimento da Cidade Submarina (cap.3) desta pesquisa e aperfeiçoado pelo uso em sala de aula. Constitui um importante achado de pesquisa e produto inédito que possibilita inúmeras possibilidades de aplicação.

Em seguida, traz o desenho da pesquisa com o objetivo de tornar claros o percurso metodológico da presente investigação e os procedimentos de abordagem do problema de pesquisa, em que, partindo dos pressupostos iniciais, realizou-se experimentos pedagógicos direcionados pela hipótese proposta.

O capítulo apresenta também outra definição importante para a compreensão das escolhas metodológicas - o conceito de pesquisa-intervenção ${ }^{1}$ - e discorre sobre os instumentos e procedimentos adotados na coleta e análise de dados.

A pesquisa foi uma pesquisa de campo, realizada em sala de aula, com abordagem qualitativa e adotando o desenho de uma pesquisa-ação, já que está relacionada ao entendimento das questões pesquisadas segundo a perspectiva dos participantes da situação estudada e à interpretação que o pesquisador faz dos dados levantados.

É uma pesquisa de campo porque, segundo Lakatos e Marconi (1991), a pesquisa de campo é definida como a observação de fatos ou fenômenos como ocorrem espontaneamente na coleta de dados a eles referentes e no registro de variáveis que se presumem relevantes para analisá-los. A pesquisa bibliográfica foi sendo desenvolvida em paralelo ao campo ou a posteriori, como meio de compreender o que dali emergia.

É pesquisa qualitativa porque esse desenho investigativo não visa medir, enumerar ou quantificar aspectos relacionados ao objeto de estudo, mas sim compreender o que foi observado em sala de aula, testando a hipótese de que a formulação de enunciados abertos segundo a taxonomia de Fink (2007) pode potencializar o

1 Pesquisa-intervenção é uma forma de pesquisa-ação, e está descrita em linhas gerais no item 2.4 deste capítulo. 
aprendizado nas disciplinas de Design Gráfico. Definindo-a segundo Lakatos \& Marconi (1991), “é uma pesquisa descritiva, cujas informações não são quantificáveis, os dados obtidos são analisados indutivamente, a interpretação dos fenômenos e a atribuição de significados são básicas no processo de pesquisa qualitativa".

O diagrama do desenho da pesquisa encontra-se na última página deste capítulo.

\section{1}

\section{Aprendizagem significativa e estilos de aprendizagem}

A aprendizagem significativa ocorre quando o estudante vê significado no que aprende. Ela acontece quando alguma nova informação se conecta a algum aspecto pré-existente na estrutura cognitiva do estudante. $\mathrm{O}$ estudante aprende pela ressignificação de conhecimentos, criando condições de aprender novas informações que se tornam base para novos conhecimentos, em um processo progressivo de construção de saberes, como numa espiral de aprendizagem.

O bom ensino deve estimular a iniciativa. Ensinar bem é ensinar apelando para as capacidades que o aluno já possui, dando-lhe, do mesmo passo, tanto material novo quanto seja necessário para que ele reconstrua aquelas capacidades em nova direção, reconstrução que exige pensamento, isto é, esforço inteligente.

Em todos os casos, a significação educativa do esforço reside no seu poder de estimulação de maior soma de reflexão e pensamento, e não na maior tensão física que possa exigir. (DEWEY, 1980, p.176)

Tais conhecimentos, ou ideias prévias, são chamados de subsunçores, ou ideias-âncora por David Ausubel (1963), e são em sua maioria conceituais.

Para Ausubel, tais conhecimentos estão interrelacionados em cadeias hierárquicas e o aprendizado de uma nova informação pode mudar ou ampliar tais ideias, causando reordenações e reestruturações do conhecimento, criando assim uma cadeia de significações que resulta em um aprendizado de compreensão e transferência, onde o aluno é capaz de explicar e descrever os conceitos que aprendeu.

A aprendizagem significativa difere da tradicional, que é calcada na memorização mecânica e aplicada a situações sem significado para os estudantes. A aprendizagem significativa está relacionada ao conceito de "aprender a aprender, que é aprendizado reflexivo, argumentativo e interpretativo.

Como a aprendizagem significativa se relaciona a aspectos internos de cada estudante, que são diferentes entre si, podemos imaginar que há diferentes modos de aprender e diferentes modos de ensinar.

O Núcleo de Inovações Pedagógicas da ESPM realiza desde 2013 uma pesquisa de estilos de aprendizagem ${ }^{2}$ dos estudantes da instituição. Em sua fundamentação 
teórica, a pesquisa mapeou mais de 70 modelos de estilos de aprendizagem que foram desenvolvidos desde 1909 e adotou os quatro estilos definidos por Honey e Mumford (1986) para analisar os estudantes:

Ativo, pragmático, reflexivo e teórico.

O estilo ativo se relaciona à disposição para novas experiências, enfrentar desafios, a agir para avaliar os resultados depois, realizar várias atividades simultaneamente, assumem posições de liderança, são empolgados, criativos e aventureiros, gostam de solucionar problemas. Não se adaptam a aulas em que seu papel não seja ativo.

O estilo pragmático é o dos estudantes que gostam de testar metodologias para ver como funcionam, buscam idéias implementáveis, são rápidos e confiantes, práticos, objetivos, realistas, organizados, gostam de aplicar o que aprenderam na prática. Aprendem melhor estudando questões do dia a dia.

Os estudantes mais reflexivos buscam refletir sobre suas ações e experiências a partir de perspectivas variadas. Aprendem por observação. Priorizam o processo ao resultado, são cuidadosos, analisam os possíveis resultados de suas ações, buscam a visão do todo observando a ação das partes. São ponderados, pacientes, detalhistas, investigativos.

Os estudantes de estilo mais teórico conseguem apoiar suas conclusões em bases teóricas, relacionando fatos que pareciam não ter conexão entre si. São racionais, perfeccionistas, analíticos, objetivos. Resolvem os problemas de forma lógica. Aprendem melhor se forem levados a questionar.

Podemos imaginar que cada estudante traz dentro de si os quatro estilos, porém alguns mais fortemente influentes e outros menos. Desse modo, o que é significativo para um, e o faria ingressar ativamente no processo de aprendizagem, pode ser irrelevante ao outro.

Os professores têm também seus próprios estilos de aprendizagem e é natural que ensinem de forma diferente, modelando seu modo de ensinar de acordo com suas próprias preferências. Há, assim, professores mais teóricos, mais ativos, reflexivos e pragmáticos, e isso em grande parte explica a afinidade que cada estudante tem com esse ou aquele professor: uma afinidade de estilo de aprendizagem.

Para que as disciplinas atinjam a todos os estudantes, criando significado e favorecendo sua participação ativa no processo de aprendizagem, é necessário planejar diferentes atividades e dinâmicas que sejam interessantes aos diferentes estilos de aprendizagem.

Fink (2007) propôs uma Taxonomia da Aprendizagem Significativa, em que apresenta seis categorias de aprendizagem significativa que podem favorecer a ativação do estudante: conceitos-chave, aplicabilidade, integração, autorrealização, importar-se, aprender a aprender. 
Pensar em atividades cujo objetivo seja atingir essas categorias é também um modo de favorecer a ativação e engajamento do estudante no processo de aprendizagem significativa. A partir da Taxonomia de Fink (2007), desenvolvi um instrumento de avaliação de atividades e aulas que será apresentado no item 2.3 deste capítulo.

\section{2 \\ Metodologias ativas de ensino-aprendizagem}

Metodologias ativas são metodologias de ensino-aprendizagem criadas para favorecer a aprendizagem significativa, ampliando as condições de aprendizagem pelo uso de recursos didáticos inovadores e de espaços criativos em aulas centradas no estudante.

São metodologias relacionadas ao mundo real, baseadas na problematização para que os estudantes vejam sentido no que estão aprendendo e estejam pré-dispostos a participar ativamente no processo de aprendizagem. A participação ativa dos estudantes traduz-se em mobilização, esforço, comprometimento e vontade de aprender.

As aulas, para o aprendizado significativo, precisam ser projetadas com base não nos tópicos e no grande volume de informações que a disciplina deve abarcar, mas nos conceitos chave, criando estratégias centralizadas no aprendizado significativo dos conceitos básicos das disciplinas e condições para o desenvolvimento de aprofundamentos pessoais dos estudantes. Esses aprofundamentos pessoais podem ser estruturados com base nas Metodologias Ativas de Ensino, através de atividades orientadas a objetivos específicos e ao acompanhamento de seu desenvolvimento pelo professor tutor, que tem o papel de facilitador, apontando caminhos de pesquisa e fornecendo pareceres e avaliações intermediárias.

(...)

O ponto de partida para o redesenho de uma disciplina baseada nas Metodologias Ativas está na definição do que se espera que o estudante aprenda. Os conceitos-chave. Em seguida, a partir desses objetivos de aprendizagem, devem ser propostos problemas e atividades que desafiem o aluno e o conduzam a atingir o conhecimento esperado.

Uma vez pensados os objetivos de cada disciplina, e criadas situações-problema que os conduzam na direção dos objetivos de aprendizagem, devem ser propostas atividades diferentes e instigantes como jogos, desafios, quizzes, projetos, pesquisas, experiências que mantenham sempre renovado o interesse nas aulas, interligando os saberes relacionados à disciplina e às demais disciplinas do curso.

(...)

A utilização da problematização nas Metodologias Ativas está relacionada ao conceito de pensamento reflexivo de John Dewey.

Segundo Dewey, (apud. DA CUNHA, 2015), O pensamento reflexivo consiste em desenvolver os conteúdos escolares tomando como ponto de partida os interesses dos alunos, a serem apresentados na forma de problemas. Os alunos, acompanhados pelo educador, devem buscar dados relativos à situação, raciocinar, formular hipóteses de solução, adotar a que parecer mais adequada e testá-la.

As soluções reveladas pelo pensamento reflexivo não são finais, mas ferramentas que utilizamos, com maior ou menor sucesso, para enfrentar novas situações problemáticas. (BELTRÃO, 2016, p.28-29) 
Aplicar metodologias ativas em uma disciplina significa redesenhar o plano de aulas, estabelecendo entre elas novas conexões que estrategicamente considerem diferentes dinâmicas que mobilizem os estudantes para a aprendizagem, indo prospectivamente ao encontro de seus diferentes pontos de significação.

\section{3 \\ Desenvolvimento do instrumento de avaliação e análise criado a partir da Taxonomia de Fink (2007)}

Na pesquisa de mestrado do autor ${ }^{3}$, a Taxonomia da Aprendizagem Significativa de Fink (2007) foi um achado de pesquisa e serviu como instrumento de análise de discurso dos professores e estudantes entrevistados, onde era possível estimar o quanto cada categoria era ou não percebida na fala.

Um dos desdobramentos propostos foi a utilização das categorias de aprendizagem significativa no planejamento de atividades didáticas, sugerindo atividades que lidassem com diferentes categorias, compondo uma combinação que abarcasse o uso de todas. Chamou-se isso de "chaveiro de atividades", pois intuiu-se que desse modo as disciplinas assim planejadas despertariam em algum momento o interesse dos estudantes, pois o "chaveiro" potencializaria a aprendizagem significativa.

$\mathrm{Na}$ ocasião, o autor desenvolveu uma pesquisa-ação em uma disciplina integrada de projeto da ESPM-Rio, onde criou uma sequência de atividades a partir desse "chaveiro", com ótimos resultados.

Como a representação da Taxonomia já havia sido utilizada para representar o planejamento de atividades e de disciplinas, e também como forma de tornar visível graficamente o discurso de professores e estudantes, um caminho natural foi propor aos estudantes que eles mesmos tentassem marcar graficamente o quanto haviam sido impactados pelas disciplinas cursadas. $\mathrm{O}$ instrumento de avaliação foi criado a partir da representação gráfica da Taxonomia da Aprendizagem Significativa de Fink.

A intenção dessa autoavaliação não é gerar notas para o professor, para as disciplinas ou para os estudantes, mas uma percepção visual de um desenvolvimento qualitativo. Desse modo, desde o início dessa pesquisa de doutorado o instumento vem sendo desenvolvido. Apresento o desenvolvimento do instrumento como Design da Informação, os resultados das análises por ele geradas aparecerão no capítulo da Cidade Submarina e nos anexos.

Cabe dizer que o desenvolvimento do instrumento de avaliação e análise, aliado ao "chaveiro de atividades", permite criar disciplinas orientadas ao aprendizado significativo, atendendo a diferentes personalidades com diferentes estilos de aprendizagem - o que deu origem a uma das proposições pedagógicas do capítulo 5.

3 Estratégias pedagógicas no ensino de Design: por uma Metodologia Ativa (BELTRÃO, 2016). 


\section{Primeira versão}

A primeira versão apresentava um desenho de seis escalas distribuídas a partir do centro, cada uma com cinco divisões, onde se esperava que os estudantes assinalassem o quanto tinham percebido ganhos ao longo do semestre na disciplina cursada.

Apliquei em uma turma na qual eu era professor e pedi a outros três professores que aplicassem nas suas. Problemas detectados: na minha turma os alunos não

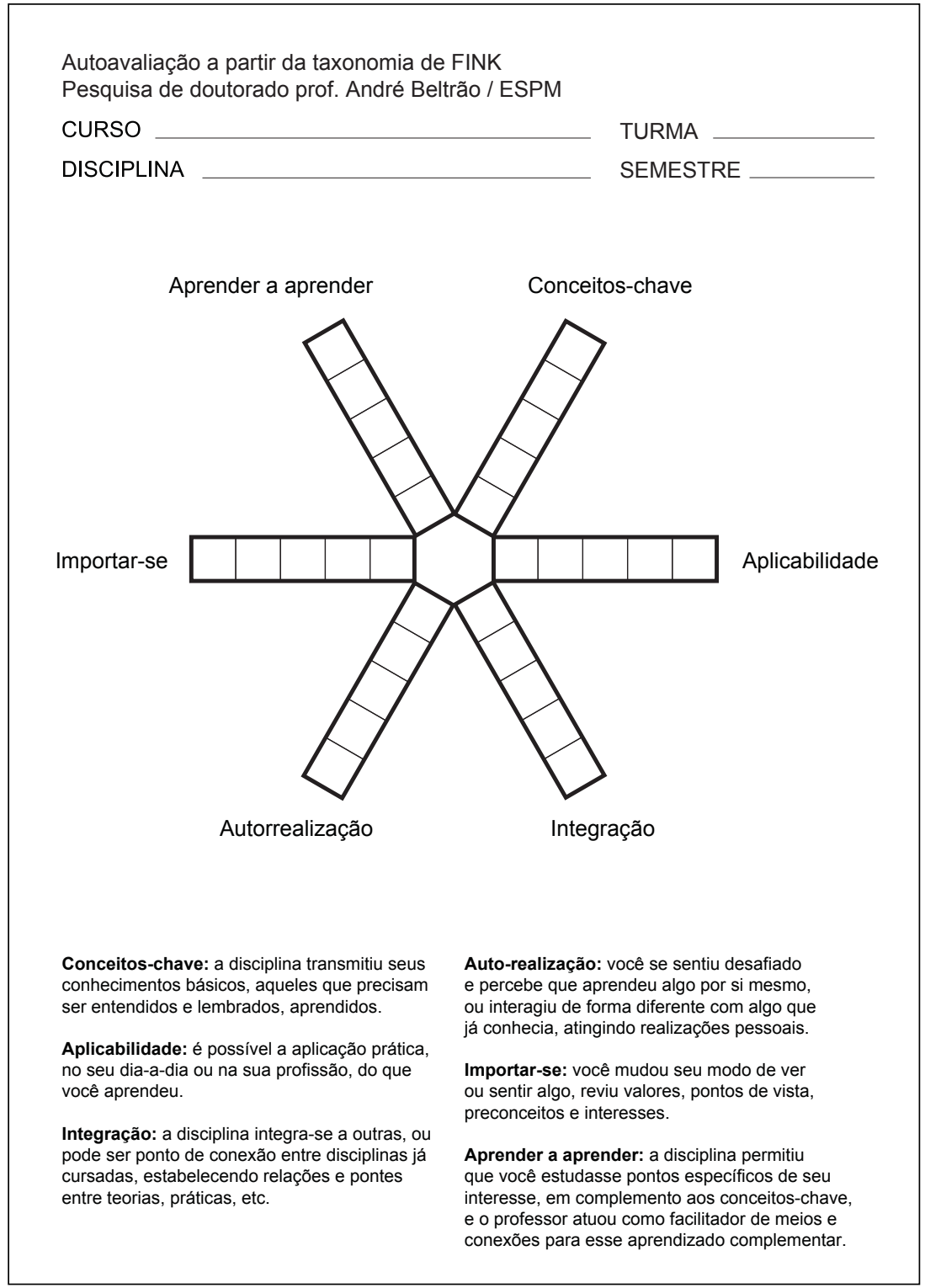

fig. 2.1 - Primeiro modelo do instrumento. Fonte: acervo do autor.

leram as informações sobre o que significavam as escalas, e pediram para explicar.

Nas demais turmas ocorreu o mesmo, e em uma delas o professor também não tinha lido e disse que não sabia responder.

Em todas as turmas houve dúvidas quanto ao sentido em que deveria ocorrer a marcação, se deveriam marcar de dentro para fora ou de fora para dentro nas escalas.

Enfim, creio que por haver cinco campos em cada escala, muitos alunos indecisos marcaram o ponto do meio. 


\section{Segunda versão}

$\mathrm{Na}$ segunda versão mudei o texto da parte inferior, tentando deixar mais claro a que cada categoria se referia.

Preparei uma ficha de apoio como instruções de aplicação para ser usada pelos professores. Testei novamente a aplicação em uma das minhas turmas e em três turmas de outros professores.

Houve menos dúvidas de professores e alunos, mas ainda assim alguns alunos marcaram a escala no sentido contrário, de fora para dentro.

Uma das categorias é, em inglês, Care e estava sendo utilizada a tradução "importar-se", que era muito clara para mim, que havia estudado a taxonomia; tinha o sentido relacionado a novos modos de ver ou sentir determinados assuntos, rever valores, pontos de vista e interesses. Percebi que para os estudantes o termo não estava sendo corretamente interpretado e a partir de conversas, descobri que era
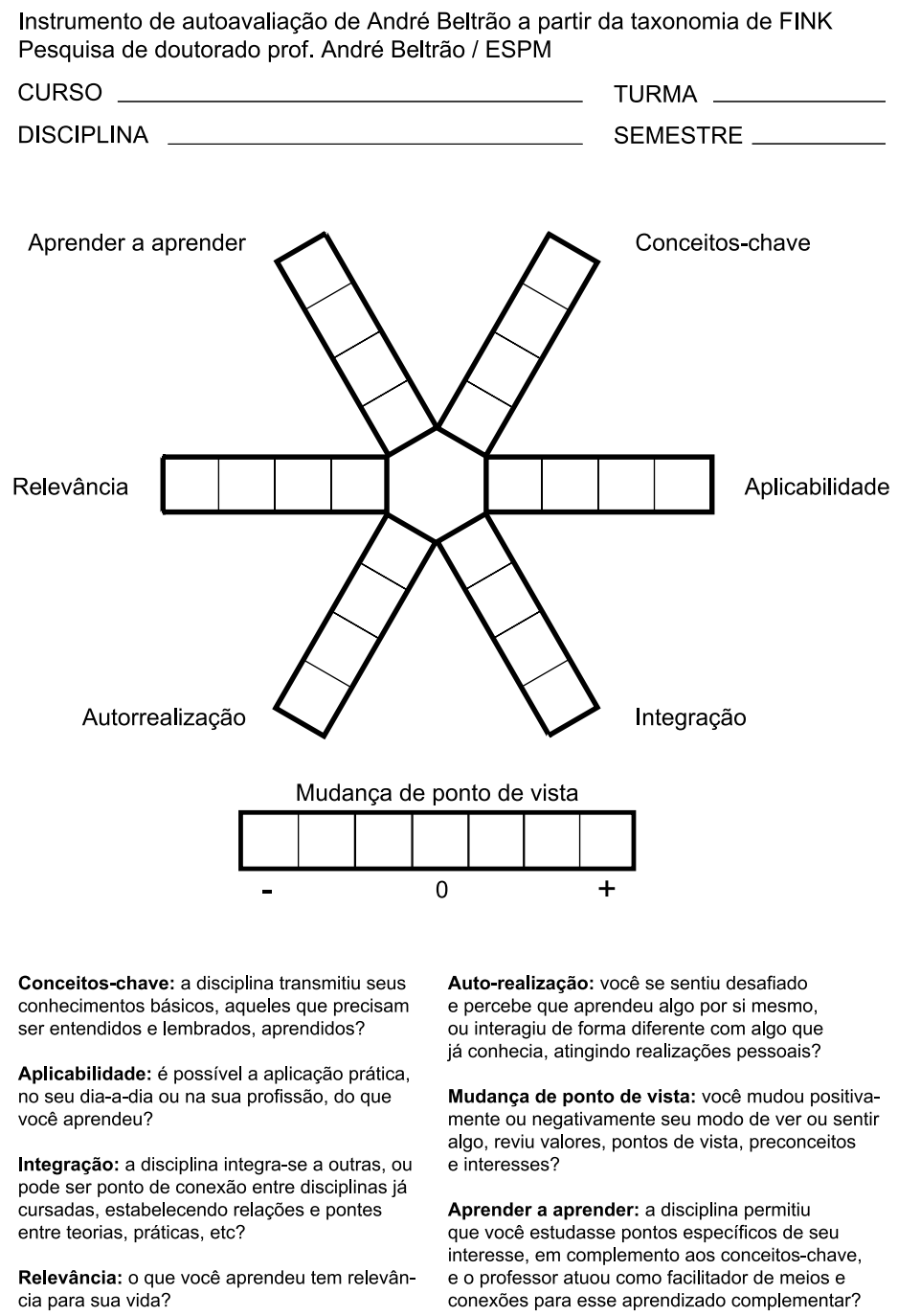

Integração: a disciplina integra-se a outras, ou pode ser ponto de conexão entre disciplinas já cursadas, estabelecendo relações e pontes entre teorias, práticas, etc? e interesses?

Aprender a aprender: a disciplina permitiu que você estudasse pontos especificos de seu interesse, em complemento aos conceitos-chave,

Relevância: o que você aprendeu tem relevân- e o professor atuou como facilitador de meios e cia para sua vida? conexões para esse aprendizado complementar? 
Autoavaliação a partir de FINK | Instruções de uso

Para que serve esse instrumento?

Este é um intrumento de autoavaliação de aprendizagem significativa dos

estudantes. Ele serve para permitir a visualização de diferentes percepções

relacionadas ao aprendizado em qualquer disciplina.

Sua utilização como instrumento de pesquisa e análise pode revelar a

percepção dos estudantes acerca de uma atividade ou de uma disciplina.

Como utilizar?

1 - O professor pode, a partir de seu plano de 3 - Ao término da pesquisa, cada item ensino, imaginar no início do semestre o deve ser tabulado em planilha para que quão relevante sua disciplina deve ser em se possa obter a média, de zero a quatro, quăo relevanter se possa obter a média, de zero a quatro,

Quais são os ganhos esperados ao término Os resultados devem ser comparados às do semestre? O estudante deve aprender em expectativas.

profundidade? Espera-se que consiga reali-

zar algo desafiador? Que ganhe autonomia?

A partir do objetivo geral da disciplina, consi- zado permite identificar falhas e planejar

derando os conhecimentos, habilidades e mudanças para o semestre seguinte.

atitudes que se deseja atingir, o professor Por exemplo: em uma disciplina em que

deve marcar em uma ficha de pesquisa o se desejava obter grande autorrealiza-

quanto imagina que seus alunos crescerão

em cada uma das categorias.

se desejava obter grande autorrealiza-

ção, mas na pesquisa essa categoria talvez as atividades não estejam

2 - No final do semestre o instrumento de suficientemente desafiadoras ou interesautoavaliação é distribuído aos alunos da santes. Em uma disciplina na qual os turma, que devem marcar o quanto adquiri- estudantes mudaram negativamente seu

ram em cada categoria. Ao aplicar a pesqui- ponto de vista sobre algo, quando a

sa, o professor deve ler para a turma as disciplina lida com temas polêmicos,

definiçōes das categorias, escritas no pé da talvez não tenham sido apresentados

página. diferentes pontos de vista ao estudante,

Deve, em seguida, dizer que o ponto central para que ele pudesse formar o pensa-

equivale ao estado inicial do aluno no início mento crítico.

do semestre, e que as escalas devem ser

preenchidas segundo a percepção de cada

um sobre o que a disciplina significou para

eles naquele semestre.

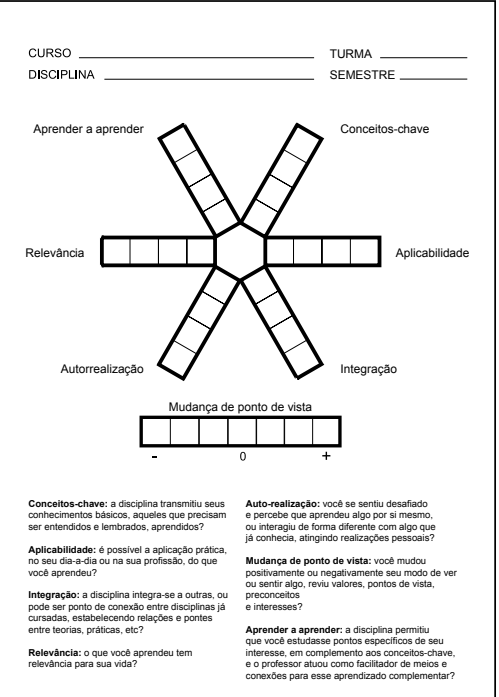

fig. 2.3 - Instruções de uso do instrumento. Fonte: acervo do autor.

compreendido como se importar em fazer um bom trabalho. Desse modo, mudei o termo para "relevância' e acrescentei uma escala em separado para "mudança do ponto de vista".

Essa nova escala (ponto de vista) tinha número ímpar de casas, sendo o central zero, onde marcações à esquerda representariam mudar negativamente e à direita, mudar positivamente.

\section{Terceira versão}

Após o teste do segundo modelo organizei uma apresentação para professores da ESPM e obtive algumas valiosas sugestões. Uma delas se referia à criação de um instrumento virtual, melhorando consideravelmente a consolidação e tratamento dos dados obtidos. A tabulação manual em planilhas de Excel é viável para turmas pequenas, mas uma aplicação em maior escala, que permitiria visualizações comparativas, é muito trabalhosa.

Como a aplicação até aqui era presencial, na terceira versão tentei um modelo totalmente diferente, baseado na escala de Likert, no Google forms.

Um ponto positivo foi poder descrever o que era cada categoria junto à sua escala, mas não foi possível avaliar dúvidas porque testei a aplicação de forma remota: os estudantes receberam um link por email.

Um ponto negativo surgiu na análise: já que todas as escalas tinham marcação muito alta, entendi que os alunos não tinham podido comparar simultaneamente as 
escalas e que o modelo anterior contemplava o preenchimento ponderado. Desse modo, imaginei que a marcação tinha sido influenciada pela satisfação dos estudantes com a disciplina como um todo.

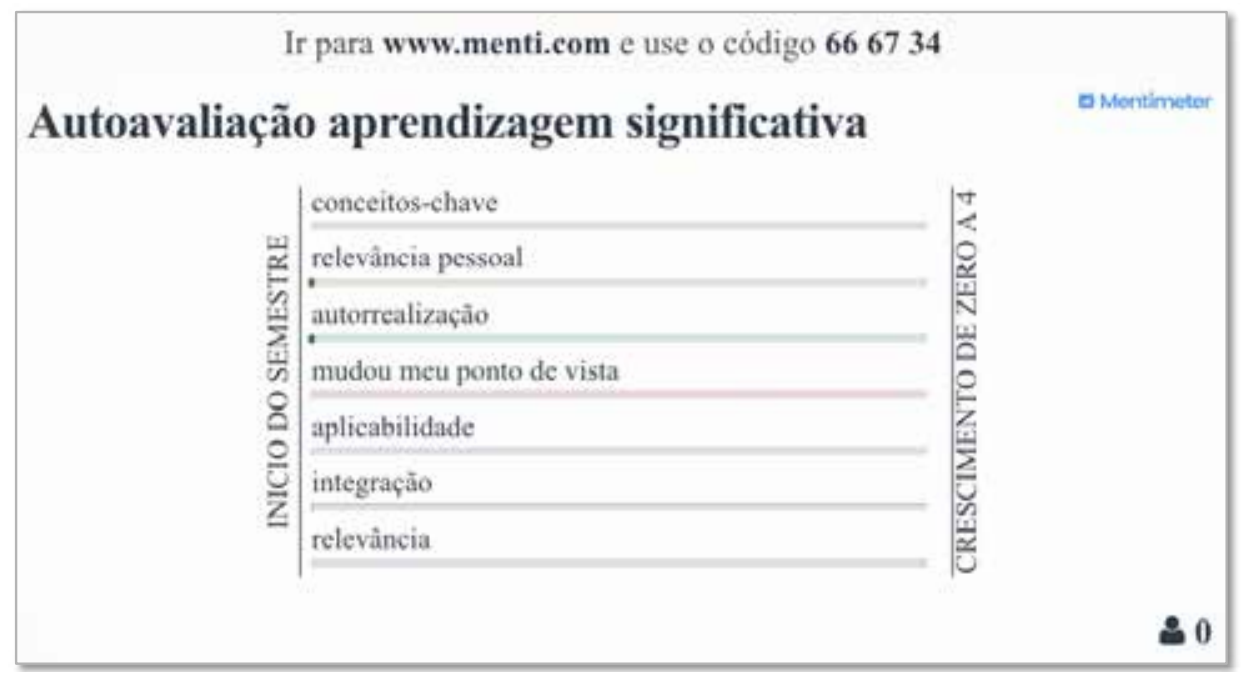

fig. 2.4 - Terceiro modelo do instrumento. Fonte: acervo do autor.

Fiz uma nova versão em outro aplicativo, o Mentimeter, que possibilitava a visualização conjunta, mas não permitia a descrição do que era cada item, o que tornava o preenchimento quase incompreensível e obtive pouquíssimas respostas a esse modelo.

Concluí que para a versão digital do instrumento precisaria ter uma solução personalizada, que visualmente se aproximasse do modelo analógico das versões anteriores. Assim, sigo buscando algum meio de viabilizar isso em paralelo ao desenvolvimento do instrumento.

\section{Quarta versão}

Voltando à segunda versão, o quarto modelo apresenta uma nova escala de mudança de ponto de vista. Retirei a possibilidade de mudança negativa e o zero, deixando sinais de menos e mais, para marcação de menor ou maior mudança de ponto de vista.

$\mathrm{Na}$ linha de mudança de ponto de vista, na segunda e terceira versões do instrumento, somente uma pessoa tinha marcado à esquerda em mais de cem, e quando perguntei a ela o que tinha mudado negativamente ela disse que isso não havia acontecido, tinha se enganado e queria dizer que havia mudado pouco. Concluí que não seria uma informação relevante e a mudança simplificaria o instrumento.

Acrescentei setas no final dos outros itens, para enfatizar a marcação do meio para fora.

No meio do gráfico acrescentei a informação de que ali era o ponto de partida: a mudança deu certo e nos testes de aplicação desse modelo ninguém marcou errado. 


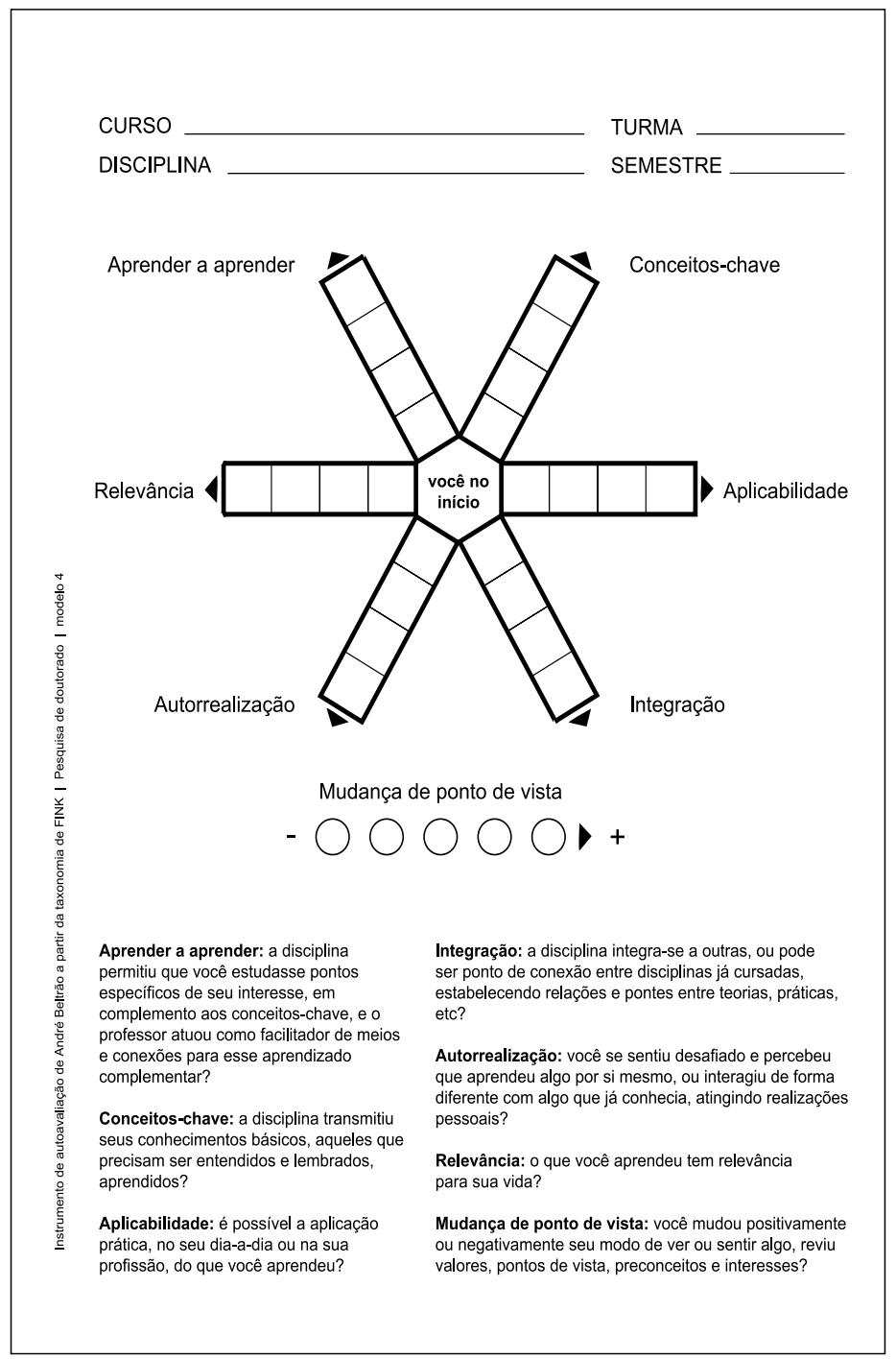

fig. 2.5 - Quarto modelo do instrumento. Fonte: acervo do autor.

O formulário ganhou um par: formulário similar dirigido ao professor para que nele marcasse suas expectativas no inicio do semestre. Desse modo, ao iniciar um semestre e planejar suas disciplinas, o professor poderia assinalar em que categorias gostaria que sua disciplina fosse mais relevante. Ao final do semestre poderia comparar o esperado com a avaliação dos estudantes e perceber visualmente o quanto sua disciplina teria caminhado na direção desejada, o que poderia levar ao replanejamento de pontos defasados para o semestre seguinte ou se havia sido tocante para os estudantes em um ponto não proposital, o que poderia ser potencializado no semestre seguinte.

\section{Quinta versão}

A aplicação do quarto modelo foi muito boa e poucos ajustes foram feitos para a quinta e mais atual versão.

Reescrevi os textos explicativos de cada categoria, a partir de dúvidas de compreensão detectadas na aplicação anterior. 
Após realizar dois treinamentos a professores na ESPM, um no Rio e outro em São Paulo, utilizando o modelo anterior, desenvolvi a partir das sugestões dos pares um terceiro formulário gêmeo para avaliação das expectativas iniciais dos estudantes.

Desse modo, o professor poderia comparar suas expectativas com as expectativas dos estudantes e com o resultado da autoavaliação final. A comparação de suas expectativas com a dos estudantes é visível logo no início do semestre e permite ajustar atividades de modo a atender o melhor possível a ambas expectativas, permitindo o planejamento das disciplinas direcionado aos alunos que as cursarão, favorecendo inclusive a aplicação da metodologia ativa conhecida como Ensino sob Medida ${ }^{4}$.

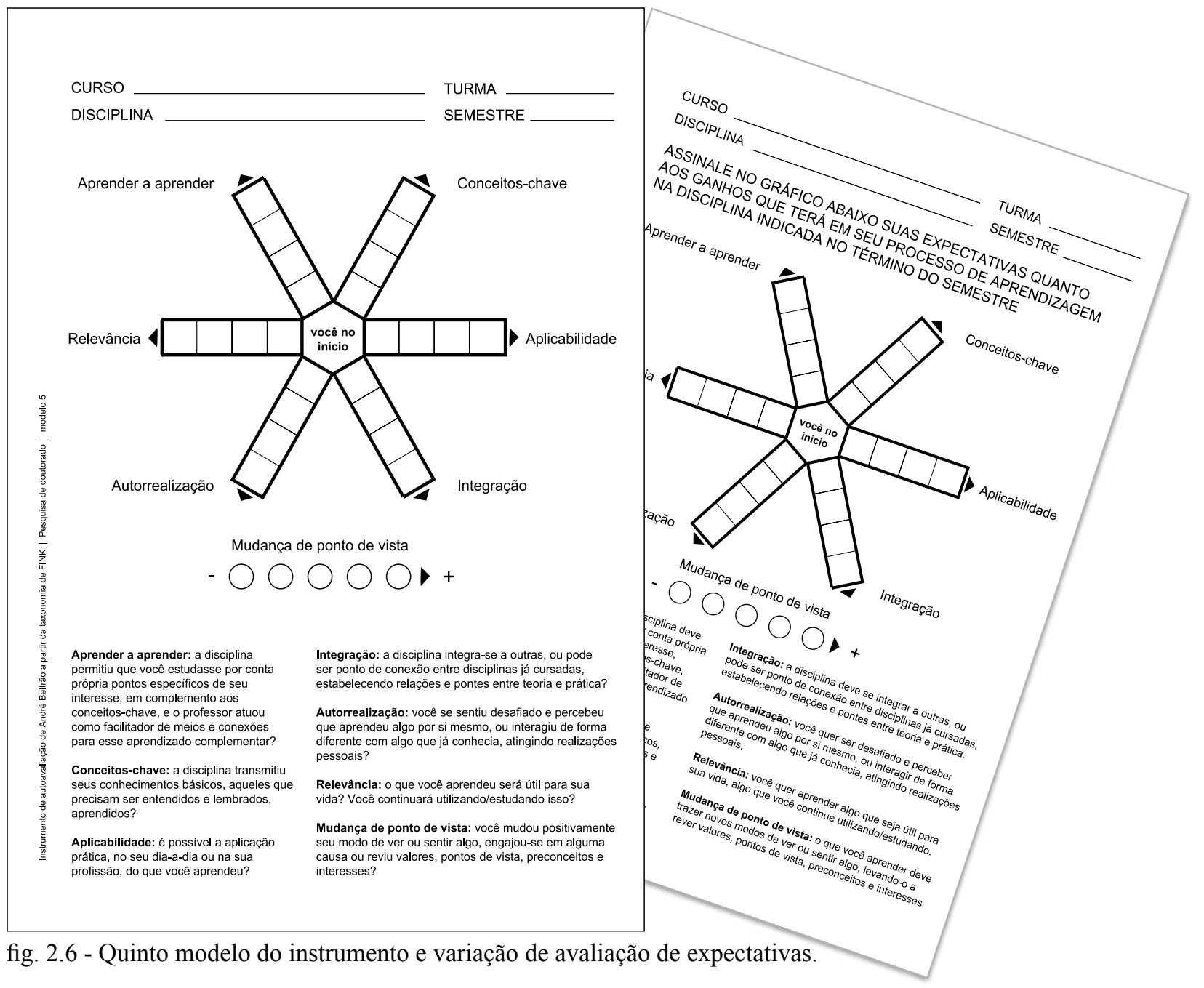

Fonte: acervo do autor.

O Ensino sob Medida está diretamente relacionado ao pensamento reflexivo e a duas categorias de aprendizagem da Taxonomia de Fink (2007): autorrealização e importar-se. É uma Metodologia Ativa de definição de conteúdos das disciplinas e, desse modo, pode ser aplicada em associação a quaisquer outras metodologias, como elemento potencializador de resultados.

4 O Ensino sob Medida foi metodologia organizada pelo professor Gregor Novak da universidade de Indiana (EUA) e colaboradores em 1999. 
A comparação final dos resultados com as expectativas dos estudantes permite visualizar o quanto foram ou não atingidas ou mesmo superadas.

\section{Exemplo de aplicação do quinto modelo do instrumento}

No exemplo abaixo estão os dados coletados em duas turmas em que lecionei no período 2019.1, ambas na ESPM. Nos gráficos, foi primeiro assinalada em cian a minha expectativa inicial, em seguida em magenta está a expectativa dos alunos, por fim, em ocre está o resultado da pesquisa final, de autoavaliação.
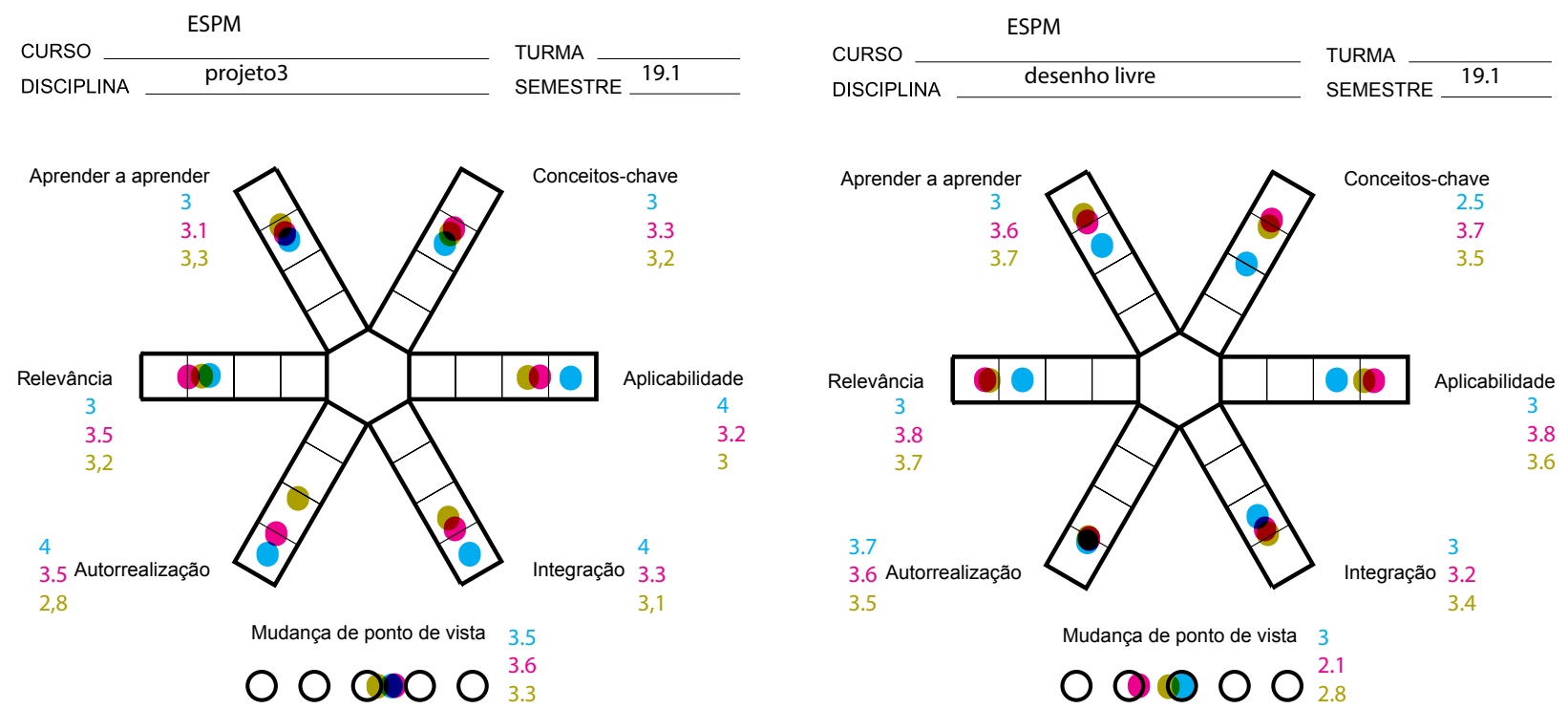

fig. 2.7 - Modelo comparativo de expectativas dos estudantes, do professor e da avaliação final.

Fonte: acervo do autor.

A disciplina Desenho Livre é do primeiro período do curso de Design e as expectativas da turma (40 estudantes) eram bastante altas, acima das minhas. Foi um semestre bastante intenso, com atividades extraclasse e o suporte do Estúdio de Desenho (vide capítulo 5). O resultado foi muito positivo, na média alcançando as expectativas dos estudantes e superando as minhas próprias.

Cabe aqui mencionar a importância disso para os cursos de um modo geral. Ao iniciar um curso superior, espera-se que as expectativas sejam altíssimas, assim como se espera que a frustração delas reduza a cada semestre as expectativas quanto ao semestre seguinte. Mapear e visualizar previamente essas expectativas pode permitir atingi-las e mantê-las elevadas por mais tempo, reduzindo a evasão dos cursos e elevando sua qualidade percebida.

A disciplina Projeto 3 é do terceiro período do curso de Design e é uma disciplina integrada às demais disciplinas do terceiro período da ESPM. O projeto 3 foi meu principal campo de estudo do mestrado, assim minhas expectativas são elevadas sobretudo nas categorias aplicabilidade, integração e autorrealização. As expectativas da turma de 2019.1 (31 estudantes) foram um pouco mais baixas que 
as minhas nessas três categorias e levemente mais altas nas outras três. O resultado final foi um pouco menor ainda em autorrealização, integração e aplicabilidade, e condizente com as expectativas nas demais.

Conversando com a turma, concluí que isso se deu por influência das demais disciplinas, em que não ficaram tão realizados, em que não perceberam tanta aplicabilidade nem integração. Como o Projeto 3 é a disciplina-eixo do período integrado, teve sua avaliação pela percepção conjunta e essa percepção fez perceber a necessidade de ajustes na condução do projeto para o próximo semestre.

\section{4}

\section{0 desenho da pesquisa}

\subsection{1}

\section{Atores da pesquisa}

A sala de aula foi meu campo de pesquisa, tendo sido palco de experimentações as turmas de Design Gráfico em que leciono na PUC-Rio e na ESPM-RJ, onde, de forma colaborativa, professores aplicaram um dos experimentos realizados.

Além de mim, foram atores da pesquisa:

Professores de Design Gráfico:

\& 14 Professores da PUC-Rio

83 Professores da ESPM-RJ

Estudantes de Design Gráfico:

(-) 300 Estudantes, aproximadamente, da PUC-Rio

(-) 200 Estudantes, aproximadamente, da ESPM-RJ

- 10 Estudantes, aproximadamente, das ESPM Porto Alegre e São Paulo

Estudantes de escolas de ensino fundamental II e ensino médio

- 100 Estudantes, aproximadamente, de três instituições de ensino médio

$\mathrm{Na}$ PUC-Rio, os professores e alunos participantes integraram as turmas da disciplina DSG1002-Projeto Básico: Planejamento, que é disciplina de projeto do segundo período letivo, nos semestres 2017.2 e 2018.1, no exercício Cidade Submarina, descrito nos procedimentos de pesquisa (item 2.3) e no capítulo 3 desta tese. Participaram também estudantes de outras disciplinas no desenvolvimento do instrumento de avaliação de análise criado a partir da taxonomia de Fink (2007), descrito anteriormente.

$\mathrm{Na}$ ESPM-RJ, os professores e alunos participantes integraram o experimento Estúdio Livre de Desenho, conforme descrito nos procedimentos de pesquisa (item 2.3) e no capítulo 4 desta tese. Participaram também estudantes de outras disciplinas no desenvolvimento do instrumento de avaliação de análise criado a partir da taxonomia de Fink (2007), descrito anteriormente. 
Um professor da PUC-Rio, um professor da ESPM-RJ e um professor de outra instituição de ensino e suas respectivas turmas de Design Gráfico e Publicidade participaram dos experimentos de briefings randômicos, também descrito nos procedimentos de pesquisa (item 2.3) e no capítulo 3 desta tese.

Dois professores da ESPM-Rio e cerca de 100 estudantes das escolas Eden, Eleva e Colégio Naval participaram de variações do exercício da Cidade Submarina, conforme descrito no capítulo 3 desta tese.

\section{5 \\ Procedimentos de realização do projeto}

A pesquisa teve como ponto de partida o estudo bibliográfico e a pesquisa de campo realizados no mestrado do autor, onde foram pesquisadas Metodologias Ativas de ensino que permitiram o estabelecimento das premissas adotadas (vide introdução) e a construção da hipótese e estabelecimento de objetivos.

Foi então delineada uma série de experimentos relacionados à investigação da motivação, da criatividade e do engajamento dos estudantes no processo de ensino-aprendizagem.

Tais experimentos foram realizados em paralelo, ao longo de seis semestres (2017.1 a 2019.2), de forma que inferências obtidas na realização de cada um deles pudessem ser utilizadas na reelaboração e reaplicação de todos.

A experimentação de campo iniciou pelo experimento de Briefings Randômicos, realizado de forma empírica em 2017.1. O experimento buscava avaliar, em exercícios rápidos, se as referências visuais e culturais dos estudantes podem atuar como bloqueios criativos e baseou-se no deslocamento do briefing para situações em que o estranhamento fez com que tais referenciais fossem reduzidos.

A partir da observação dos resultados desse experimento, criei o exercício projetual Cidade Submarina, realizado como uma pesquisa intervenção nos semestres 2017.2 e 2018.1. A Cidade Submarina, descrita no capítulo 3 desta tese, ampliou o deslocamento dos referenciais dos alunos pela criação de uma heterotopia ${ }^{5}$ (Foucault, 1984), possibilitando condições que potencializaram a aprendizagem significativa. Como objeto de pesquisa-intervenção, o exercício foi documentado no semestre 2018.1 através do registro aula a aula (diário de bordo), de registro fotográfico, de instrumento de autoavaliação criado e de entrevistas com os alunos

5 Heterotopia, como definida por Foucault (1984), é uma cápsula de fuga da realidade paralela ao mundo cotidiano, uma espécie de utopia realizada. Foucault difere as heterotopias das utopias comparando essas últimas a um reflexo de si mesmo que alguém pode ver no espelho, uma imagem projetada, irreal, um não-lugar, enquanto o espelho existe, e o reflexo que está no espelho olha na direção da pessoa real, conectando o espelho, a pessoa e sua imagem em uma heterotopia. 
e com professores participantes. A Cidade Submarina buscou avaliar o quanto a transposição dos estudantes para uma realidade ficcional poderia contribuir para a redução de bloqueios criativos impostos pelo filtro da realidade e verificar o quanto a adesão e preparo dos professores são importantes para o aprendizado significativo.

Três aplicações de uma versão reduzida do exercício projetual Cidade Submarina foram experimentadas em escolas de ensino fundamental e médio, objetivando observar como o universo ficcional atua sobre o pensamento criativo em estudantes que não tiveram ainda contato com quaisquer aprendizados relacionados ao Design.

Buscando avaliar condições de aprendizagem ativa em que o professor não dá aulas, mas atua como um tutor, e o processo de aprendizagem é diretamente protagonizado pelos estudantes, criei o Estúdio Livre de Desenho na ESPM-RJ em 2018.1. Através da observação participante puderam ser definidos precedimentos e características que permitiram constituir uma estrutura de aprendizagem colaborativa inspirada nos grupos operativos, cujo desenvolvimento foi observado e registrado nos semestres 2018.2, 2019.1 e 2019.2. A pesquisa no Estúdio Livre de Desenho constitui o capítulo 4 desta tese.

Os objetivos específicos da atividade foram quebrar bloqueios criativos dos alunos pela quebra de paradigmas, motivar a criatividade e o engajamento pela disrupção dos padrões, avaliar o quanto diferenças culturais de estudantes das duas intituições podem ser percebidas nos resultados atingidos e criar ambiente colaborativo de autoaprendizagem.

Os professores de cada instituição fizeram registro fotográfico do processo e dos resultados, que foram compartilhados em espaço colaborativo virtual e o professor tutor e três estudantes de cada escola foram entrevistados.

Nos experimentos realizados, pesquisei através de questionário a autoavaliação dos estudantes segundo suas percepções de aprendizagem das categorias da Taxonomia do Aprendizado Significativo de Fink (2007). Para essa autoavaliação, desenvolvi e aperfeiçoei um instrumento próprio de análise a partir de Fink (2007), conforme relatado no item 3.1 deste capítulo.

Os experimentos foram desenvolvidos, registrados e analisados com apoio de pesquisa bibliográfica de Design, Psicologia, Educação, Linguística e áreas afins. A partir de todas as análises realizadas, concluí a pesquisa propondo estratégias pedagógicas.

O desenho e os procedimentos da pesquisa estão ilustrados em diagrama na última página deste capítulo. 


\section{6 \\ Pesquisa-intervenção}

Damiani (2012) afirma que as intervenções em educação, sobretudo aquelas relacionadas ao processo de ensino/aprendizagem, podem simultaneamente propor novas práticas pedagógicas e produzir conhecimento teórico nelas baseado.

Segundo a autora, a pesquisa-intervenção é uma pesquisa-ação em educação, em que são propostas interferências, mudanças e inovações propositadamente realizadas por professores ou pesquisadores, em suas práticas pedagógicas, com base em referencias teóricos, objetivando aprimorar essas práticas.

Segundo Morgrovejo (2001), a pesquisa-ação gera um escopo teórico baseado na ação, teoria que ajuda a diagnosticar problemas e a buscar ações alternativas que podem confirmar ou levar a revisões do próprio quadro teórico com base em avaliações constantes. Pode ser considerada uma teoria em construção.

Segundo Tripp (2005), a pesquisa-ação é um dos tipos de investigação-ação, que é um termo genérico para qualquer processo que siga um ciclo no qual se aprimora a prática pela alternância entre agir no campo da prática e investigar a respeito dela. Planeja-se, implementa-se, descreve-se e avalia-se uma mudança para a melhora de sua prática, aprendendo mais, no correr do processo, tanto a respeito da prática quanto da própria investigação.

Ainda segundo o autor, a pesquisa-ação deve ser contínua, pois deve ser um trabalho regularmente desenvolvido para melhorar algum aspecto dela, sendo pró-ativa nas mudanças, dado que suas mudanças são ações baseadas na compreensão alcançada por meio da análise das informações de pesquisa, onde os julgamentos devem ser feitos com base nas melhores evidências que se possa produzir. A pesquisa-ação é participativa e colaborativa na medida que envolve todos os que dela participam.

Como grande parte do que acontece na prática pode não ser percebido ou registrado, seu progresso é comumente documentado pela organização de um portfólio dos experimentos, cujo critério principal de prática é que funcionem bem. Quando não funcionam, cabe compreender o problema e projetar mudanças na situação.

Segundo Thiollent (2014), a pesquisa-ação compreende quatro fases: fase exploratória, onde são identificados os atores e realizados diagnósticos iniciais; fase de pesquisa aprofundada, na qual ocorre a coleta de dados; fase de ação, onde se planeja ações para atingir os objetivos definidos; e fase de avaliação, onde ocorre nova observação, redirecionamento das ações e resgate dos achados de pesquisa. As três últimas fases podem ocorrer em simultaneidade de pesquisa e ação.

Faz parte desse tipo de pesquisa o registro passo a passo dos experimentos com vistas a desenhar um percurso metodológico que possa posteriormente servir de base para outras atividades que tenham o mesmo fim. 
A pesquisa compreende, ainda, o uso de sessões de gravação de apresentações feitas para posterior análise, além de entrevistas com os alunos participantes, com vista a identificar os principais resultados dos experimentos e inovações no decorrer da pesquisa-ação, necessitando a criação de instrumentos de registro que permitam analisar os procedimentos didáticos adotados bem como os resultados dos experimentos realizados.

Todos os experimentos desenvolvidos nessa tese caracterizaram-se como pesquisas-intervenção por buscarem as práticas pedagógicas transformadoras mencionadas por Damiani (2012), no entanto elegeu-se o experimento Cidade Submarina para ser relatado como pesquisa-ação no capítulo cinco, com todos os registros e análises que são marcadores dessa modalidade de pesquisa.

\section{7 \\ Instrumentos de pesquisa}

Para a consecução dos objetivos propostos, usei cinco tipos de instrumentos de pesquisa: a observação direta, o registro de aulas, a análise Fink (2007) de práticas pedagógicas, o questionário e a entrevista.

\section{- A OBSERVAÇÃO DIRETA}

Segundo Lakatos (1991, p.191), “a observação ajuda o pesquisador a identificar e obter provas a respeito de objetivos sobre os quais os indivíduos não têm consciência, mas que orientam seu comportamento".

Segundo Selltiz (1965, apud Lakatos, 1991), a observação torna-se científica quando adequada a um plano de pesquisa, quando é sistemática, quando é registrada metodicamente e quando está sujeita a verificações e controles.

Em minha pesquisa, a observação direta deu-se em sala de aula, nas disciplinas de Design Gráfico relacionadas aos experimentos realizados. Nas aplicações da Cidade Submarina a observação se deu na disciplina de Projeto II; foi observação participante na turma em que leciono, e não participante nas turmas conduzidas por outros professores. No Estúdio Livre de Desenho a observação foi participante, porém não inserida no contexto de uma disciplina formal, mas de atividade extraclasse.

A observação foi contínua, sistemática e participante, permitindo comparar os resultados obtidos nos diferentes períodos letivos em que foram realizadas as experimentações. Esses resultados não foram necessariamente formais (trabalhos realizados), mas também conceituais e comportamentais.

- O REGISTRO DE AULAS

O registro foi construído por mim sob a forma de um "diário de bordo" 
da disciplina de Projeto 2 do curso de Design Gráfico da PUC-Rio no semestre 2018.1, em diário aula a aula de tudo que aconteceu na pesquisa-intervenção realizada na disciplina observada, aliado ao registro fotográfico, período que foi o segundo semestre da pesquisa-ação desenvolvida na disciplina.

Os dados contidos nesses registros fazem parte do experimento Cidade Submarina e se encontram detalhados no capítulo 4 e nos anexos desta tese.

\section{- O QUESTIONÁRIO}

Questionários são instrumentos de coleta de dados que permitem descrever características e medir variáveis de um grupo social.

Segundo Marconi \& Lakatos (2016), um questionário consiste em um conjunto ordenado de perguntas que devem ser respondidas por escrito e sem a presença do entrevistador a deve despertar o interesse do recebedor de modo que ele preencha e devolva o questionário em tempo razoável. Deve prever as facilidades para o preenchimento e devolução do mesmo.

As autoras apontam, dentre pontos positivos dos questionários, a economia de tempo e a possibilidade de atingir um grande número de pessoas ao mesmo tempo, respostas não identificadas e não influenciadas pelo pesquisador.

O questionário foi utilizado nessa pesquisa como instrumento de análise do experimento Cidade Submarina e como referência para a elaboração das entrevistas realizadas naquele experimento.

\section{- A ENTREVISTA}

Além da observação direta, realizei entrevistas não estruturadas, focalizadas com alunos e com professores de Design Gráfico que participaram dos experimentos.

Segundo Lakatos (1991), as entrevistas não estruturadas são aquelas onde o entrevistador não está preso a uma entrevista rígida, com perguntas padronizadas, com perguntas abertas e a possibilidade de explorar mais especificamente alguma questão que venha à tona, em uma conversação informal. As entrevistas focalizadas são aquelas em que há um roteiro de tópicos relativos ao tema estudado, porém sem questões pré-definidas, que o entrevistador percorre livremente durante a entrevista.

Como marcador e parte da documentação da pesquisa-ação desenvolvida na turma de Projeto II em 2018.1, foram entrevistados três professores e quatro alunos das turmas observadas, sendo dois entre os alunos de grupos com melhor desempenho, e dois de grupos de desempenhos intermediários.

Como parte da documentação do Estúdio Livre de Desenho, e subsídio para reavaliação e planejamento de mudanças para o semestre seguinte, ao término dos semestres 2018.2 e 2019.1 foram entrevistados três alunos que participaram com 
frequência do Estúdio Livre, sendo um do primeiro período do curso, um de período intermediário (do segundo ao quarto período) e um de períodos finais (quinto ao oitavo período).

O protocolo de pesquisa foi submetido e aprovado pelo Conselho de Ética da PUC-Rio.

\section{- A ANÁLISE DE PRÁTICAS PEDAGÓGICAS A PARTIR DE FINK}

A partir da Taxonomia da Aprendizagem Significativa de Fink (2007), descrita na introdução e no início deste capítulo, elaborei o instrumento de autoavaliação que buscava medir o impacto de disciplinas, experimentos e exercícios nos estudantes participantes (vide item 2.3, no início deste capítulo). A primeira versão do instrumento seguia exatamente o desenho da interseção das seis categorias de aprendizagem significativas, tal como propus que fossem utilizadas no planejamento das aulas e atividades. Ao aplicar esse questionário visual, pedi aos estudantes que imaginassem o centro como o ponto de partida antes da disciplina que estaria sendo avaliada, e que a partir daí marcassem na escala dividida em cinco quadrados o quanto imaginavam que tinham adquirido em cada categoria daquelas ao longo da disciplina.

O instrumento de autoavaliação criado por mim a partir de Fink (2007) passou a ser utilizado como instrumento de verificação do planejamento de disciplinas, aulas e de atividades pedagógicas.

O professor, ao formular a atividade ou disciplina, pode planejá-la para atingir as categorias de aprendizagem significativas desejadas. A seguir pode sondar as expectativas dos estudantes e, ao término, pode rodar a autoavaliação para verificar a percepção dos estudantes quanto ao que adquiriram. Caso o resultado coincida com suas expectativas, poderá aprimorar sua atividade dentro dos mesmos parâmetros. Caso o resultado seja diferente de suas expectativas, pode visualizar caminhos para modificar a atividade. Além disso, o resultado pode trazer informações inesperadas que contribuirão para o processo. 


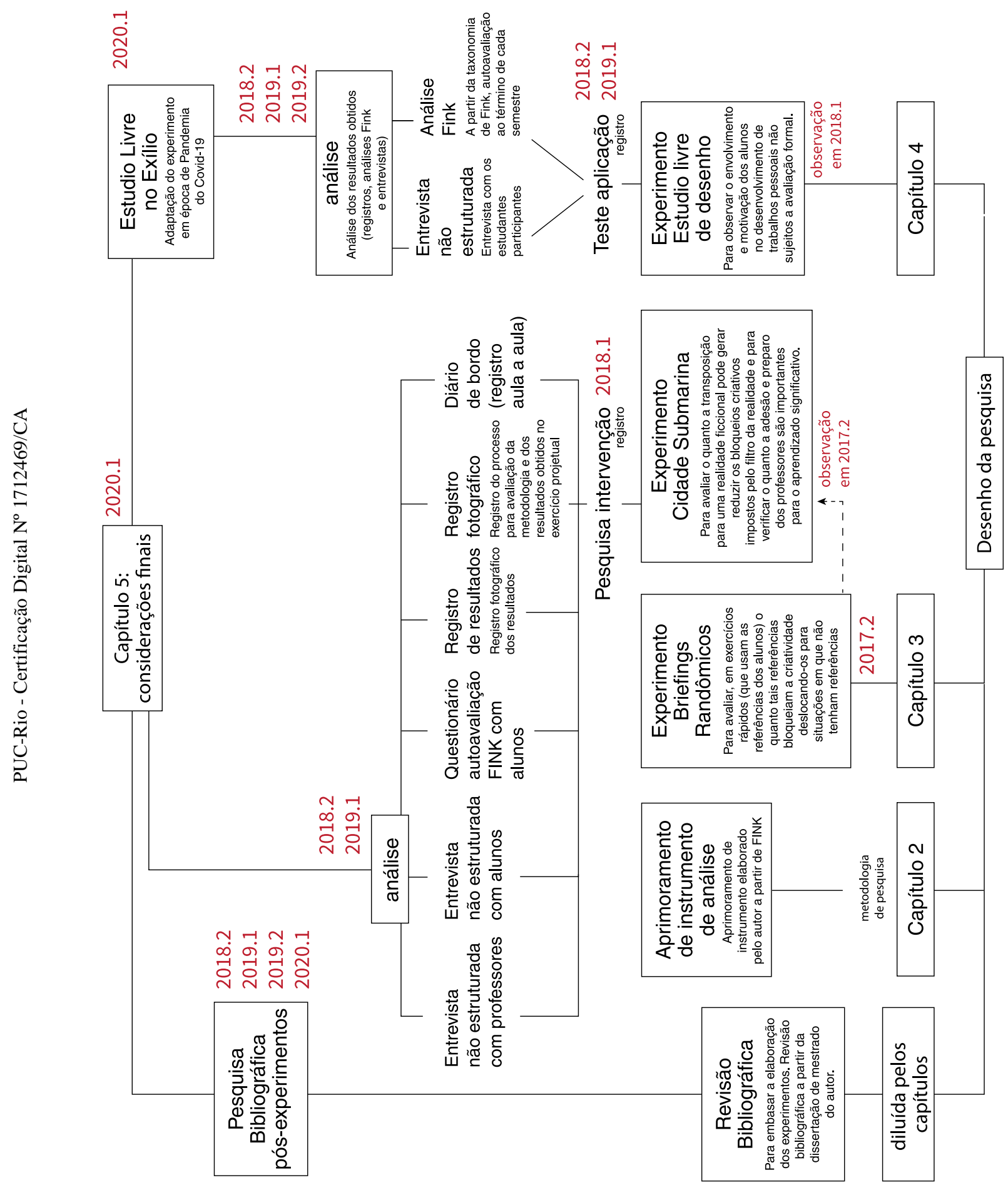

fig. 2.8 - O desenho da pesquisa. Fonte: acervo do autor. 


\section{3 \\ Cidade Submarina: \\ o pensamento divergente e o estranhamento como condutores de uma heterotopia criativa}

Este capítulo descreve o principal experimento de campo desta pesquisa, iniciado a partir dos briefings randômicos, no primeiro semestre de 2017, e desenvolvido sob a forma de pesquisa intervenção na PUC-Rio no segundo semestre de 2017 e primeiro semestre de 2018 , e em seguida testado em versões reduzidas em três escolas de ensino médio, os colégio Eleva, Éden e o Colégio Naval.

As práticas de ensino de Design aqui relatadas foram criadas com base em uma biblioteca pessoal constituída por uma bagagem interdisciplinar que foi remexida e recombinada para a criação do exercício projetual "Cidade Submarina", realizado nas seis turmas de Projeto II do curso de Design da PUC-Rio nos dois semestres citados.

Cabe aqui fazer uma reflexão sobre o projetar em Design como uma atividade interdisciplinar.

Enquanto atividade interdisciplinar, o Design permite olhares sob diversos ângulos às situações, enxerga o homem, o espaço, a atividade, os materiais, as limitações e muitos outros aspectos que se interrelacionam de forma complexa. $\mathrm{O}$ Designer cria projetos para o mundo real, em que vive, modificando no processo o mundo e também a si mesmo, pois aprende ao contextualizar o que vê.

Bomfim (1997, p. 28), ao abordar a relação entre teoria e prática do Design, ressalta que o Design, assim como outras áreas de conhecimento, tem a consolidação de seus conhecimentos teóricos a partir da experiência. No caso do Design, porém, de forma diversa dessas outras áreas, a prática demanda conhecimentos de diferentes ramificações das ciências clássicas que se constituíram antes do Design, como a Estética, a Matemática, a Psicologia. Dessa forma, segundo o autor, uma Teoria do Design não se fundaria em teorias próprias, nem se enquadraria em nenhum dos grupos clássicos da ciência por ser igualmente interdisciplinar ou transdisciplinar. O Design faz fronteira com muitas áreas do conhecimento, sobretudo aquelas relacionadas à criatividade.

Já que mencionamos a criatividade, como é um item essencial aos experimentos desta tese, cabe defini-la.

Segundo Hokanson, apud Fernandes (2014), a criatividade é uma habilidade mental que todos usamos para resolver nossos problemas do dia a dia e todos somos 
criativos. É um erro isolar a criatividade em certos campos como a arte e não incorporá-la à vida. $\mathrm{O}$ autor afirma que a criatividade pode ser desenvolvida com a prática e isso é potencializado quando nos expomos a ambientes e situações diferentes daquelas a que estamos habituados, porém isso requer a coragem de propor coisas novas.

O pensamento criativo já foi no passado atribuído a inspirações divinas, à influência de gênios e já foi associado à loucura por romper com os padrões estabelecidos.

Guilford (1950) afirmou que a criatividade é uma forma de pensamento divergente, e que pode ser medida em termos de fluência, flexibilidade, originalidade e elaboração. Segundo essa visão, é mais criativo quem tem um volume maior de ideias e cujas ideias que se afastam do que é óbvio, esperado para cada situação.

Tal concepção era considerada, na época, apenas cognitiva, pois estaria associada aos processos mentais de percepção e associação de ideias. A partir da década de 1980, porém, passou-se a considerar não somente esses aspectos cognitivos mas também os emocionais da criatividade como influenciadores dos processos criativos, como humor, fantasia e perspectiva incomum (Torrance, 1966).

Há quem se perceba mais criativo em momentos alegres e leves e há quem se perceba mais criativo em momentos tristes, quando tem o tempo que quiser para criar ou quando está sob pressão de prazos.

Em oposição ao pensamento divergente, o pensamento convergente se refere à análise, à síntese, à redução de opções. O modelo escolar do ensino médio é convergente, pois está pautado pela produção de respostas certas. Segundo David et al (2014), o modelo escolar é pautado pela intolerância ao erro, à fantasia e à imprevisibilidade e isso pode representar muitas dificuldades para quem é criativo e pensa de forma divergente.

Robinson (2006) afirma que a pressão pelo pensamento convergente traz aos indivíduos o medo de cometer erros no processo de criação de uma ideia e que esse modelo escolar aos poucos vai matando a criatividade.

Land, Jarman (1990) constataram, em pesquisa desenvolvida para a NASA, que em um mesmo grupo de 1600 indivíduos, aos 5 anos de idade 98\% eram considerados indivíduos altamente criativos. Tal percentual caiu para $30 \%$ quando os indivíduos do mesmo grupo atinguram 10 anos de idade e para $12 \%$ quando atingiram 15 anos de idade. Em um grupo maior, de duzentos mil indivíduos maiores de 25 anos, apenas $2 \%$ eram altamente criativos. Isso está diretamente relacionado aos bloqueios criativos, e mais profundamente ao condicionamento de não errar.

Os estudantes do segundo período de Design, aos quais foi proposto o exercício projetual da Cidade Submarina, acabaram de sair do ensino médio e têm ainda muitos bloqueios. Quebrar esses bloqueios foi um dos principais objetivos do exercício, potencializando o pensamento divergente. 
Para que isso fosse favorecido, utilizou-se o estranhamento, quebrando os padrões mentais previamente estabelecidos pelo deslocamento da realidade ao inserirmos os estudantes em um contexto ficcional.

Charles Watson (2013, p.214-220), em seu curso de imersão criativa, enfatiza a necessidade de olharmos para algo que estamos fazendo com estranhamento, distanciamento, dizendo que há situações na produção de uma obra em que é preciso olhar para algo cotidiano como se o estivéssemos vendo pela primeira vez e repensar o papel de cada elemento. Desse modo viabilizamos olhar para aquilo que todo mundo vê e pensar em algo diferente.

A Cidade Submarina foi um exercício projetual interdisciplinar com três semanas de duração. Os objetivos do experimento foram (1) quebrar os bloqueios criativos gerados pelas limitações técnicas dos alunos na produção de modelos, (2) motivar a criatividade e o engajamento pela disrupção dos padrões, (3) aprimorar a introdução de conteúdos teóricos relacionados a metodologia de pesquisa e geração de ideias, minimizando a resistência ao aprendizado, e (4) avaliar o papel do professor no processo, no quanto seu engajamento afeta o exercício.

\section{1}

\section{Briefings randômicos}

No primeiro semestre de 2017 fui convidado a lecionar em uma turma de Planejamento Criativo do curso de Publicidade da ESPM. Nessa disciplina os alunos recebem acompanhamento criativo de seus trabalhos de conclusão de curso no segundo bimestre e no primeiro bimestre fazem uma série de exercícios de criação publicitária como "aquecimento". Cabe dizer que eram três turmas da disciplina e eu recebi dos outros professores a estrutura da disciplina pronta, bem como os exercícios iniciais.

O primeiros desses exercícios era feito a partir de um sorteio de situações variadas, como "lançamento de um perfume de luxo", "inauguração de um hotel tal" ou "inauguração de uma nova linha de vôos para tal lugar". Os estudantes se dividiam em duplas, sorteavam um desafio e precisavam criar uma imagem-conceito dessas campanhas para a aula seguinte.

Observando os resultados, todos se pareciam com alguma coisa que já tínhamos visto. Não me refiro aqui à identificação com referências do público-alvo, que é uma das bases da publicidade, pois se uma campanha não for identificada por seu público ela será ineficaz. Essa identificação se faz em parte pela familiaridade com elementos, signos e alusões presentes nos referenciais do público-alvo. Refiro-me a todas as campanhas serem muito parecidas com alguma outra que já vimos antes, uma colagem de campanhas anteriores. 
Conversei com a turma sobre o processo criativo deles e foram unânimes em dizer que pesquisaram campanhas similares, pesquisaram referências de vídeos e de anúncios com o mesmo tema e para o mesmo público e das pesquisas colheram insights sobre que tipo de imagem deveriam usar, qual tipografias escolher, que tom deveria ter o texto ${ }^{1}$.

Pensei então em propor briefings absurdos, para os quais eles não pudessem encontrar paralelos tão diretos, imaginando que talvez isso os obrigasse a pensar em soluções originais. Propus então um segundo exercício onde cada grupo precisaria sortear três cartas, cada baralho continha uma parte do problema e as combinações obtidas randomicamente seriam a campanha a ser trabalhada.

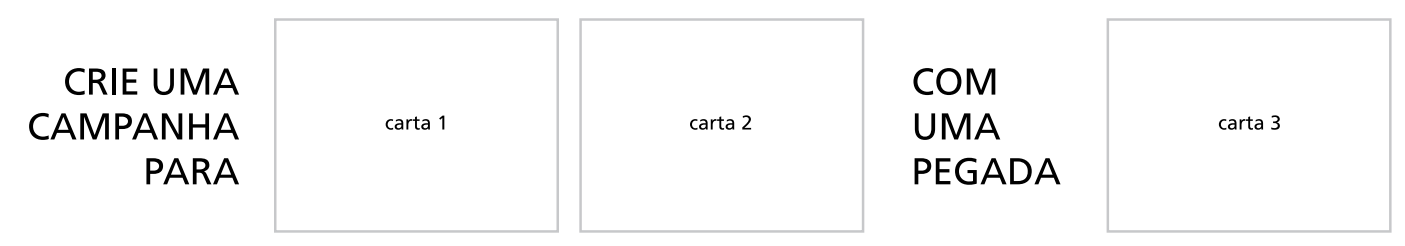

fig. 3.1 - Enunciado do exercício, com espaço para colarem as cartas sorteadas.

Fonte: acervo do autor.

O sorteio das cartas produziu combinações mais comuns e combinações absurdas, como era esperado. A lista de palavras possíveis (fig. 4.2) previa isso.

Foi interessante perceber que os grupos que tinham sorteado combinações maiscomuns produziram layouts mais comuns, como vinham fazendo, porém os grupos que sortearam combinações inusitadas produziram conceitos de layout muito mais criativos. Debatemos os resultados atingidos e a turma percebeu essa diferença. Argumentaram que na maioria das situações as campanhas lidarão com coisas comuns e não tão instigantes e disseram que tinham percebido que ser criativo a partir do usual é mais difícil que ser criativo a partir do fantástico. Respondi que, a meu ver, permitir o exercício da criatividade no fantástico contribuiria para que conseguissem ser mais criativos no usual, pois o tempo curto os leva a usar muito daquilo que já pensaram ou viram antes.

Uma das combinações sorteadas foi: "Crie uma campanha para a inauguração de um restaurante budista com uma pegada descolada" e resultou em um layout minimalista com tons amarelos claros, vermelhos e azuis, desses que dão uma sensação de já termos visto em algum lugar.

Outra combinação foi "Crie uma campanha para divulgar uma sessão de bruxaria de musica eletrônica com uma pegada de leste europeu" e o grupo criou uma campanha inspirada em lambe-lambes de videntes, utilizando referências visuais que lembravam ciganos e bastante cor. $\mathrm{O}$ resultado foi muito bom e criativo.

1 Esse é um problema presente também nas turmas de Design: muitas vezes as referências são colhidas em sites como pinterest, e recombinadas para produzirem layouts muito parecidos entre si. 


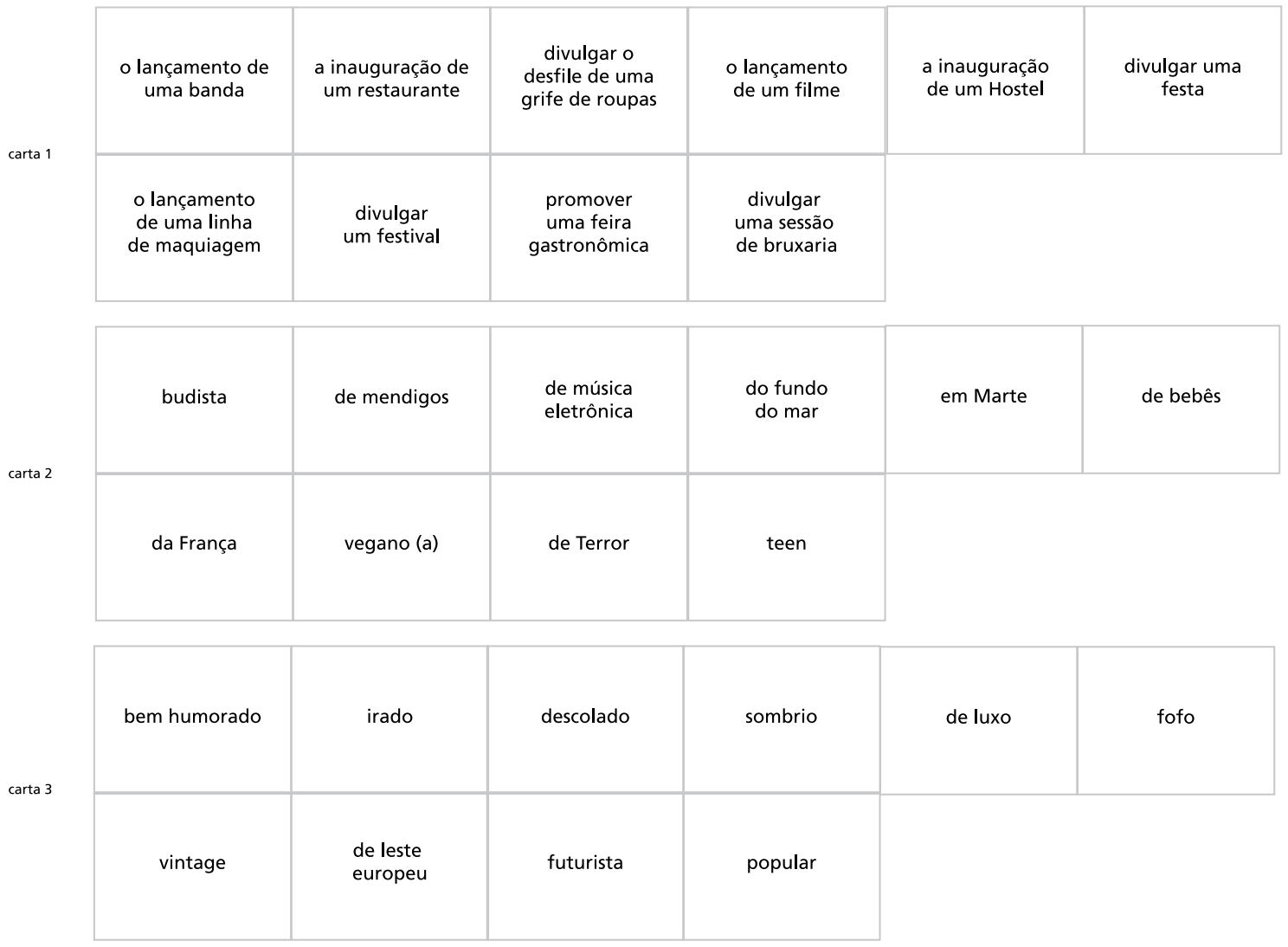

fig. 3.2 - Cartas do exercício Briefings Randômicos. Fonte: acervo do autor.

Não registrei o resultado desse exercício, pois então não considerava que poderia fazer parte da pesquisa de doutorado. Ele foi, porém, inspiração para a elaboração da Cidade Submarina no semestre seguinte. Percebi que o sorteio de combinações inusitadas de cartas gerava o estranhamento citado por Watson (2013, p.214-220), causando assim uma ruptura de padrões cognitivos e a consequente redução do bloqueio de errar na criação, favorecendo o pensamento divergente.

\section{2}

\section{A disciplina adotada: Projeto II}

As disciplinas de projeto são a espinha dorsal dos currículos de praticamente todos os cursos de Design oferecidos no país. A partir dos projetos as demais disciplinas de cada semestre se articulam e se integram, colaborando para a aprendizagem projetual dos estudantes.

Há, no entanto, uma interessante contradição presente nas disciplinas projetuais: o estudante deve aprender a projetar a partir do exercício de desenvolver um projeto sobre um tema proposto, ou seja, precisa entender as etapas e valorizar o desenvolvimento, compreendendo como ele conduz ao resultado, no entanto o estudante tende a valorizar o resultado, quer pular etapas, é avesso à teoria e quer logo a prática. 
O Projeto I do curso da PUC-Rio é realizado por cada grupo de alunos junto a um parceiro e o desenvolvimento está muito relacionado aos processos de produção e experimentação de modelos funcionais que se tornam artefatos desenvolvidos para o uso específico daquele parceiro escolhido.

O Projeto II amplia esta visão mostrando que da mesma forma que uma pessoa precisa de algo, potencialmente há diversas outras pessoas com necessidades similares. Ao invés de projetar um artefato, o designer pode projetar pensando em escala de produção, e assim os modelos deixam de ser vistos como o produto final, mas como uma etapa de desenvolvimento e de representação. Dessa forma, os estudantes não precisam lidar somente com materiais que conhecem e que podem manipular: papelão, acrílico, madeira, couro, isopor podem representar madeira, vidro, aço e quaisquer outros materiais e processos imaginados.

Quando chegam ao Projeto II, porém, os alunos estão condicionados à única proposta de método projetual que conheceram, ou seja, a do Projeto I, e é frequente que muitos deles não se mostrem receptivos a outras abordagens metodológicas. Isto faz com que tentem criar projetos baseados nas habilidades construtivas que já possuem, utilizando os materiais e processos que já haviam experimentado anteriormente, pensando em artefatos e não em processos ou produtos que possam beneficiar um maior número de usuários.

Desse modo, ao serem apresentados ao primeiro exercício projetual da disciplina, muitas vezes buscam o que lhes é familiar e tal prática afeta o pensamento criativo, atuando de forma convergente como foram condicionados por muitos anos.

O exercício projetual Cidade Submarina foi concebido como uma câmara de descompressão para aplicação no início do Projeto II.

\section{3}

\section{A Cidade Submarina}

Pensando na dimensão semiótica ${ }^{2}$ de projetar, considerando a fala como o projeto, podemos ver a situação-problema como um significante inserido em um contexto no qual os estudantes são participantes. Desse modo, influenciados pelo modo de olhar que já utilizam, como uma linguagem de projeto, criam significados muito próximos de si.

2 Semiótica, segundo Santaella (1989, p.15), é a ciência que tem por objeto de investigação todas as linguagens possíveis, ou seja, que tem por objetivo o exame dos modos de constituição de todo e qualquer fenômeno de produção de significação e de sentido. A semiótica define língua e fala como componentes da linguagem, onde o sistema de interpretação e uso dos signos adotado por um grupo social caracteriza a língua, enquanto o uso individual, que dá existência e materialidade à língua, é a fala. 
Lorieri (2008, p.3) afirma que em cada contexto cada elemento tem significação específica devida, também, ao próprio contexto: nada tem significado isoladamente ou fora de algum contexto. Os contextos são o "berço" das significações dos diversos elementos: em cada contexto diferente, os elementos ganham significações diferentes.

Pensando em tudo isso, resolvemos mergulhar...

Com base nesses conceitos semióticos, o exercício partiu da criação de um novo contexto, onde os estudantes foram inseridos. A criação desse contexto implicou a produção de uma narrativa de cunho científico, aos moldes da ficção cientifica verniana, com dados de ficção misturados a dados e tecnologias reais ou, ao menos, passíveis de existir. Imaginei que um novo contexto deslocaria os significados e possibilitaria falas (layouts) diferentes.

A estrutura de ficção científica foi escolhida por se tratar de um gênero no qual é inerente a interação entre estranhamento e cognição, e que é uma alternativa imaginativa ao ambiente empírico da ciência (Sauvin, 1979).

Essa narrativa, ainda que fictícia, tinha diversos pontos de contato com o mundo real, criando pontes que foram usadas na construção metodológica do exercício.

\section{Primeira aplicação, semestre 2017.2}

A Cidade Submarina foi um exercício projetual com 3 semanas de duração.

Criamos uma cidade no fundo do mar, fundada por cientistas brasileiros em uma dessas crises econômicas, como uma sociedade perfeita e heterotópica. A descrição da cidade, do contexto e de seus habitantes foi inicialmente feita de forma vaga, através de uma notícia publicada em jornal. A notícia foi diagramada de forma realista e era datada de algumas semanas antes da aula.

Um segundo recorte de jornal, mais recente, trazia uma notícia preocupante: na atual crise, diversos brasileiros tentaram fugir para a cidade submarina, como fazem os refugiados que se arriscam em pequenos barcos rumo à Europa, ou os cubanos rumo à Florida, e do mesmo modo se afogaram ou conseguiram chegar. A repentina quebra da tranquilidade com o grande aumento populacional causou à comunidade problemas de desabastecimento e desemprego, e trouxe à tona questões relacionadas ao uso dos recursos, à cultura e sociedade, trazendo paralelos com problemas similares que enfrentamos no mundo real.

Tais recortes (vide anexos) foram apresentados aos alunos das seis turmas de Projeto II no primeiro dia de aula, por meio digital, e precisavam ser lidos antes da aula começar. As turmas todas foram reunidas para o briefing do exercício, que foi apresentado com naturalidade pela professora Roberta Portas, como tendo sido uma demanda apresentada pelo conselho de anciãos da Cidade, que ouvira falar do curso de Design da PUC e queria que os estudantes fizessem uma imersão na Cidade para proporem projetos que melhorassem as novas situações que se apresentavam. 


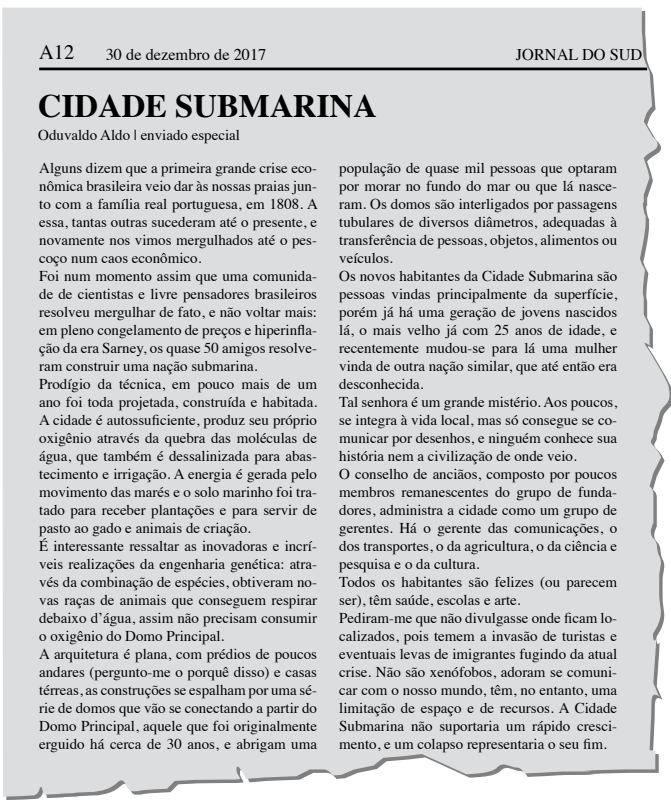

fig. 3.3 - Recortes de jornal, parte do briefing da Cidade Submarina (vide anexos)

Fonte: acervo do autor

Perplexos, formaram grupos de trabalho e precisaram planejar o que perguntariam aos habitantes da Cidade Submarina. Foram em seguida conduzidos a duas salas onde estes os aguardavam para serem entrevistados.

Doze professores estavam representando papéis abertos, isto é, tinham cada um uma função na administração ou na vida da Cidade, mas apenas uma definição muito suscinta do que faziam e do que pensavam. Alguns tinham combinado previamente o que dizer para não caírem em contradição, mas ao longo das entrevistas tais contradições ocorreram com grande frequência.

Os estudantes não tinham planejado direito o que perguntar e a quem perguntar. Isso fez com que perguntassem, por exemplo, sobre comunicações à responsável pela moda, sobre moda ao agricultor, sobre construção e transporte ao cientista, além de perguntarem o que cabia mesmo a cada um responder.
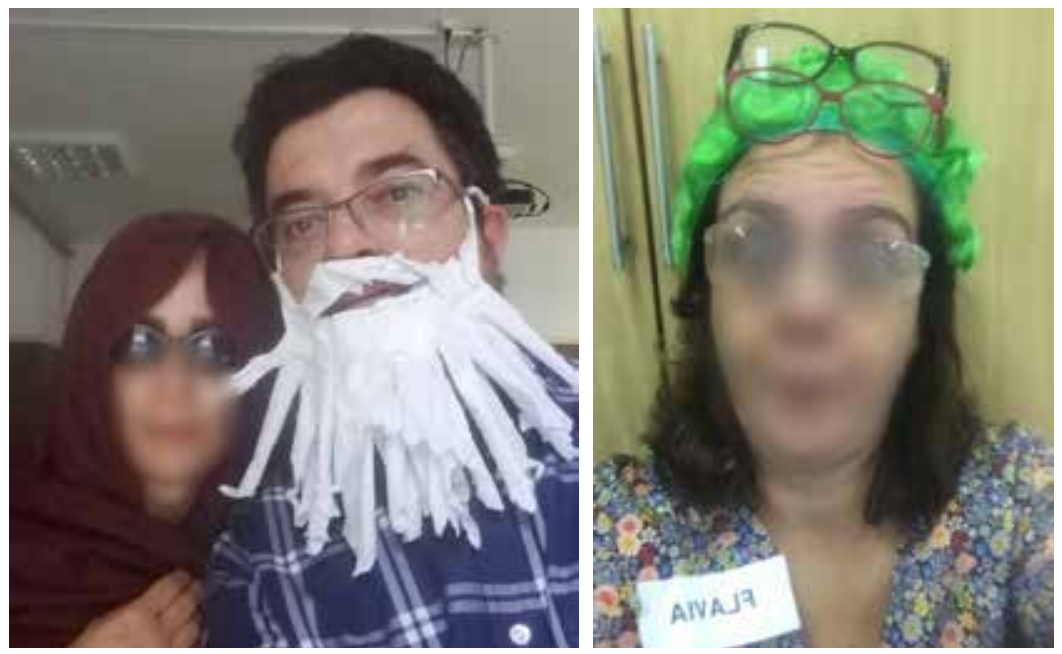

fig. 3.4 - Professores caracterizados de improviso: (da esquerda para a direita) estrangeira misteriosa, ancião e gerente de pesquisa. Fonte: acervo do autor. 
Para a segunda aula, deveriam sintetizar o que tinham apreendido das entrevistas, e apresentaram informações totalmente contraditórias. Foi uma aula sobre pesquisa, onde aprenderam técnicas de pesquisa e mapeamento de palavras-chave para levantamento de dados. Aprenderam que devem buscar as fontes mais adequadas e confiáveis, e que poderiam traçar paralelos entre as situações da Cidade e as do mundo real.

Em seguida tiveram aula de planejamento, para poderem aprender a articular as etapas de desenvolvimento dentro do prazo disponível, e foram para as salas de projeto para o início do exercício com mediação dos professores de Projeto II. Em sala, receberam cartas onde precisavam desenhar cinco objetos identificados na entrevista com os moradores, cinco desenhos de situações identificadas na pesquisa bibliográfica ou de dados secundários e escrever cinco verbos (um em cada carta).

$\mathrm{Na}$ aula 3, partindo das cartas, tiveram aula de representação bidimensional, com técnicas para representação de ideias, e nas salas de projeto fizeram uma dinâmica de criatividade em que uma carta de cada tipo foi sorteada, compondo uma sequência a partir da qual os grupos deveriam gerar ideias com a abordagem "criar". O mesmo processo repetiu-se para as abordagens "transformar" e "romper", onde "criar" significava criar algo usando os elementos selecionados - os conteúdos são combinados; "transformar" significa dar novos usos ou criar novas possibilidades - os conteúdos devem ser os mesmo porém pensados para um outro propósito - diferente aos quais foram inicialmente projetados e "romper" significa desmontar as partes que compõem o objeto e dos elementos da situação e usar como ingredientes para uma novo objeto ou situação.

A aula 4 foi dedicada à produção de modelos, e os estudantes aprenderam em laboratório técnicas de construção de modelos volumétricos que pudessem ajudar a demonstrar o funcionamento e o uso das soluções criadas, seguida de aula de orientação para construção de modelos e simulação.

A aula 5 foi dedicada ao planejamento e preparação da apresentação das proposições. Os estudantes desenvolveram estratégias de apresentação e de organização visual dos materiais, e receberam orientação para construção das apresentações e simulações.

A última aula foi dedicada à apresentação de todos os grupos, com seis minutos cada um, com todas as turmas reunidas.

A Cidade Submarina constituiu-se como uma heterotopia, como definida por Foucault (1984), uma cápsula de fuga da realidade paralela ao mundo cotidiano, uma espécie de utopia realizada. Foucault difere as heterotopias das utopias comparando essas últimas a um reflexo de si mesmo que alguém pode ver no espelho, uma imagem projetada, irreal, um não-lugar, enquanto o espelho existe, e o reflexo que está no espelho olha na direção da pessoa real, conectando o espelho, a pessoa e sua imagem em uma heterotopia.

As heterotopias, segundo Foucault (1984), sempre possuem um sistema de abrir e fechar que ao mesmo tempo as isola e as torna penetráveis; nelas o acesso 
não é livre e para entrar é preciso ter permissão. A Cidade Submarina é bem planejada, perfeita, meticulosamente organizada, uma heterotopia de compensação. Era de se esperar que fosse invadida após ter sido conhecida por todos.

Segundo nossa história, assim que a notícia sobre a Cidade Submarina foi publicada, muitos correram para lá fugindo da crise econômica atual, e muitos se afogaram tentando, mas cerca de 200 indivíduos conseguiram chegar e passar pelos portões do Domo principal.

Foucault (1984) diz que quem consegue penetrar na heterotopia acredita ter entrado, mas isso é ilusório, pois pelo próprio fato de ter entrado, é excluído. Nessa questão reside a origem de todos os problemas que a Cidade Submarina passou a enfrentar com a invasão dos imigrantes ilegais - falta de recursos, desemprego, violência, preconceito, saúde, problemas do nosso mundo que foram reconstruídos no contexto-espelho.

Não bastava aos novos moradores estarem na Cidade Submarina, eles precisavam se integrar à vida daquele lugar, porém eram tão numerosos que sua presença trouxe problemas complexos que levariam muito tempo para serem resolvidos, com grande esforço.

Foi interessante perceber a diferenças e semelhanças entre o que foi desenvolvido em cada turma. Quatro delas apresentaram projetos mais inusitados e utilizando elementos de ficção misturados à realidade, e foi nítido perceber o quanto alguns alunos se divertiram e tiveram prazer em fazer o exercício. Em duas turmas os projetos foram mais apegados ao mundo real, preocupados com a resistência e adequação dos materiais e processos para produtos reais, o que não era objetivo do exercício.

O deslocamento de realidades visava libertar a criatividade na concepção de produtos factíveis ou não, e o contato com metodologias de pesquisa, planejamento e desenvolvimento de forma fluida, ativa.

Criar uma situação projetual configurada como um problema aberto em um contexto ficcional complexo e conectado ao mundo real possibilitou muitos "encaixes" para os pontos de partida motivacionais e permitiram que os estudantes se engajassem ativamente no projeto.

O exercício projetual criado foi interdisciplinar, lidando em sua estrutura com a semiótica e com a construção de uma narrativa, com representação teatralizada no briefing, com planejamento e metodologia de pesquisa na aula 2 , com desenho e técnicas de representação na aula 3, com materiais e processos na aula 4, com diagramação e percepção visual na aula 5 e com apresentação na aula 6. Foram utilizados todos esses componentes para compor um exercício complexo e denso, porém envolvente como um jogo, ou um desafio.

Para Japiassu (1977), ao questionar os conhecimentos adquiridos e os métodos aplicados, não só a atividade interdisciplinar promove a união do ensino e da pesquisa, 
mas transforma as escolas: de um lugar de simples transmissão ou reprodução de um saber pré-fabricado, num lugar onde se produz coletiva e criticamente um saber novo.

\section{Segunda aplicação, semestre 2018.1}

Em relação ao semestre anterior, fizemos algumas mudanças de aprimoramento na construção da trama, no briefing, no planejamento metodológico e na organização e operacionalização do exercício.

Com relação à construção da trama, incluí alguns detalhes técnicos sobre a Cidade Submarina que sequer haviam me ocorrido quando redigi a primeira versão do exercício. Tais detalhes se mostraram necessários devido às especulações dos alunos no semestre anterior.

Defini que a cidade ocupava uma área de $11 \mathrm{~km}$ por $9 \mathrm{~km}$, distando $35 \mathrm{~km}$ do continente e situando-se a uma profundidade de 115 metros. Essas dimensões e localização foram demarcadas em uma carta náutica do litoral do Rio de Janeiro, definições sugeridas pelo capitão submarinista Helio Branco, com quem me reuni para saber outras informações sobre submarinos, câmaras pressurizadas, comunicação e navegação no fundo do mar, que usei também na composição de meu personagem, o Ancião.

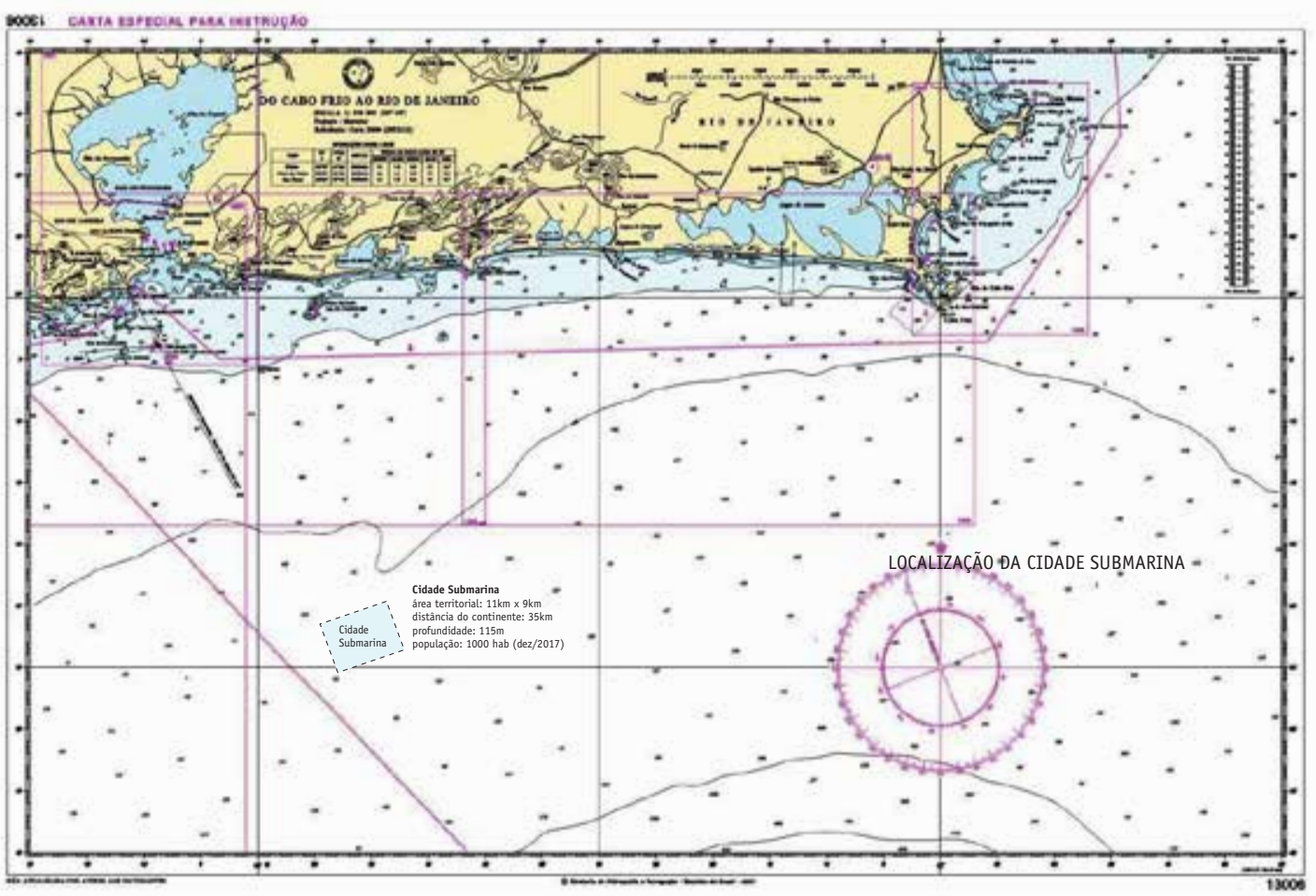

fig. 3.5 - Carta náutica com localização da Cidade Submarina (vide anexos). Fonte: acervo do autor. 
Ampliando o detalhamento, montei uma planta baixa da cidade, situando suas construções dentro da área territorial. Defini detalhes de como são organizados os domos da cidade, que tamanho possuem e o que contêm, a posição dos tubos de transporte.

Fizemos duas reuniões de planejamento com todos os professores do segundo período, a segunda delas dedicada a esse exercício projetual. Nessa reunião revisamos os papéis dos professores e discutimos os detalhes de configuração da cidade submarina, colaborativamente.

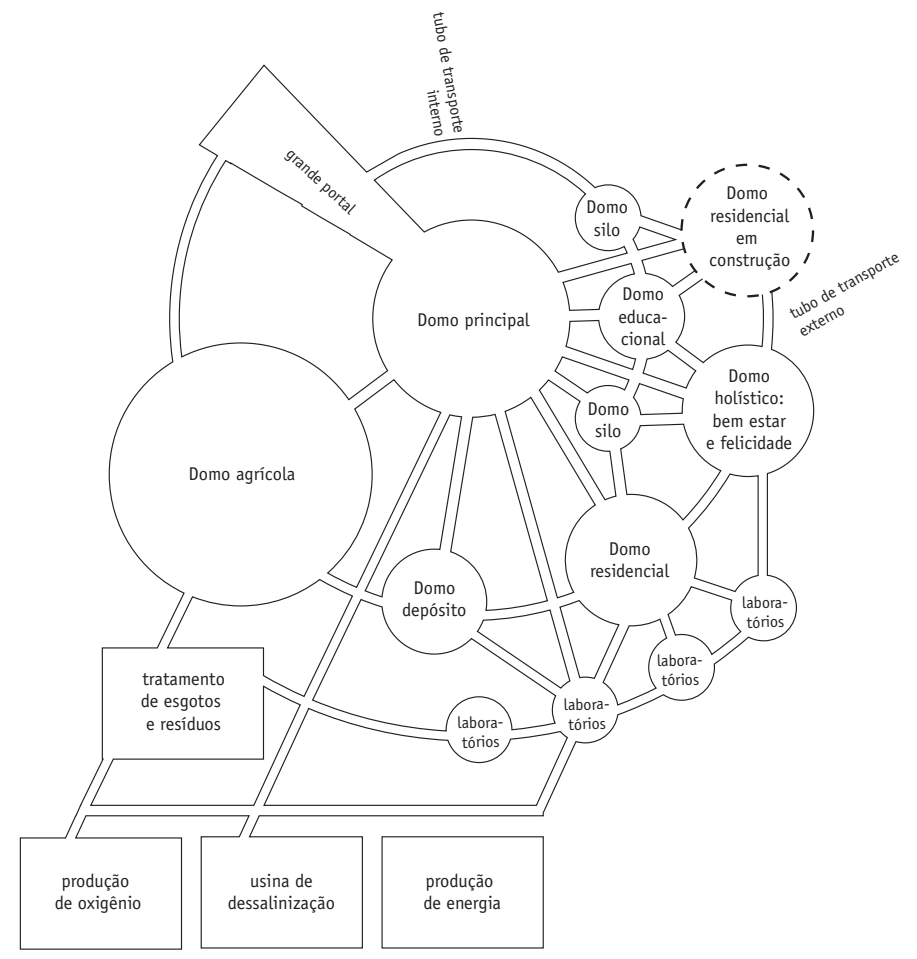

fig. 3.6 - Planta baixa da Cidade Submarina: domos e tubos de transporte. (vide anexos). Fonte: acervo do autor.

Com relação à história, eliminamos possíveis pontos de conflito que haviam sido identificados na primeira aplicação do exercício - eliminamos a existência de imigrantes ilegais, os imigrantes passaram a ser refugiados, pois isto havia dado margem a discussões sobre autoritarismo e política, não muito pertinentes ao exercício.

Eliminamos a descrição de animais geneticamente modificados (gado com guelras), pois tinham gerado discussões éticas. As pesquisas genéticas na segunda edição eram secretas, e garantiu-se que eram baseadas apenas em modelos computacionais, não em organismos vivos.

Uma importante questão a ser investigada através desse exercício projetual é o quanto os alunos se sentiram motivados para participarem do projeto, se criaram soluções mais criativas por terem sido transportados para uma realidade diferente, heterotópica e em que medida percebem que as soluções propostas poderiam ser adaptadas ao mundo real em que vivemos. 
Outra questão importante a ser avaliada nesse exercício projetual é a inserção de conteúdos teóricos. Um dos pressupostos desta pesquisa diz que os estudantes de Design são muito resistentes a conteúdos teóricos em disciplinas de projeto, pois têm a expectativa de que vão vivenciar algo de natureza totalmente prática.

Os conhecimentos teóricos, no entanto, são muito importantes, sobretudo os relacionados a aspectos metodológicos do projeto. No exercício projetual da Cidade Submarina os alunos têm contato com metodologia de projeto, com metodologias de entrevistas, com análise das fontes, com processos de brainstorm e geração de ideias.

Desse modo, a professora Rita Couto preparou uma aula sobre entrevistas, outra sobre brainstorming e outra sobre análogos e similares. Cada aula contava com uma folha impressa, contendo informações teóricas sobre o tópico, e previa uma dinâmica que seria realizada em sala de aula. Reordenamos as aulas em relação ao semestre anterior, iniciando cada etapa por uma aula teórica a ela relacionada, e mergulhando em seguida na Cidade Submarina para aplicação imediata do que havia sido praticado.

\section{Papéis (atores)}

Para obtermos uma imersão maior na ficção da Cidade Submarina, predispondo os estudantes ao estranhamento, incluímos um novo componente: o humor.

De acordo com Santos (2009), Aristóteles postulou que o humor é uma espécie de ridiculez e contribui para a argumentação do orador antecipando a ideia de incongruência.

Tabacaru (2015) define a teoria da incongruência como uma das principais formas de humor. É uma teoria cognitiva baseada na diversão que está contida no que é inesperado. $\mathrm{O}$ inesperado origina-se no contraste entre alguma expectativa e algo diferente dela, significando algo diferente do que foi antecipado pelos padrões mentais do ouvinte.

A partir da teoria da incongruência do humor, imaginei papéis a serem desempenhados pelos professores, caracterizados por artefatos, figurinos e acessórios estranhos.

Os professores das seis turmas e os professores colaboradores da disciplina ganharam papéis administrativos na Cidade. Divididos em funções gerenciais, doze dos quatorze professores assumiram gerências de cultura e lazer, transportes, moda, ciência, felicidade, educação, agricultura e pecuária, arquitetura e indústria. Um dos professores cuidava das redes sociais, outro era responsável pela assessoria de imprensa. Um membro do conselho de anciãos, oriundo do grupo original de cientistas que constituíram a cidade, também estava representado. Contamos, ain- 
da, com uma professora no papel de uma estrangeira misteriosa que só conseguia se comunicar por desenhos e um investidor patrocinador das pesquisas na Cidade Submarina.

Em reunião prévia foi compartilhada com os professores uma breve descrição de cada personagem (vide anexo). Porém, propositalmente deixei margem para criação e improviso, de modo que cada professor pudesse imaginar a personalidade do seu personagem e improvisar respostas para as perguntas dos estudantes.

Os estudantes receberam a listagem de moradores da Cidade Submarina por meio digital, juntamente com os textos que precisariam ser lidos antes da primeira aula.

Planejamento da Cidade Submarina 2018.1

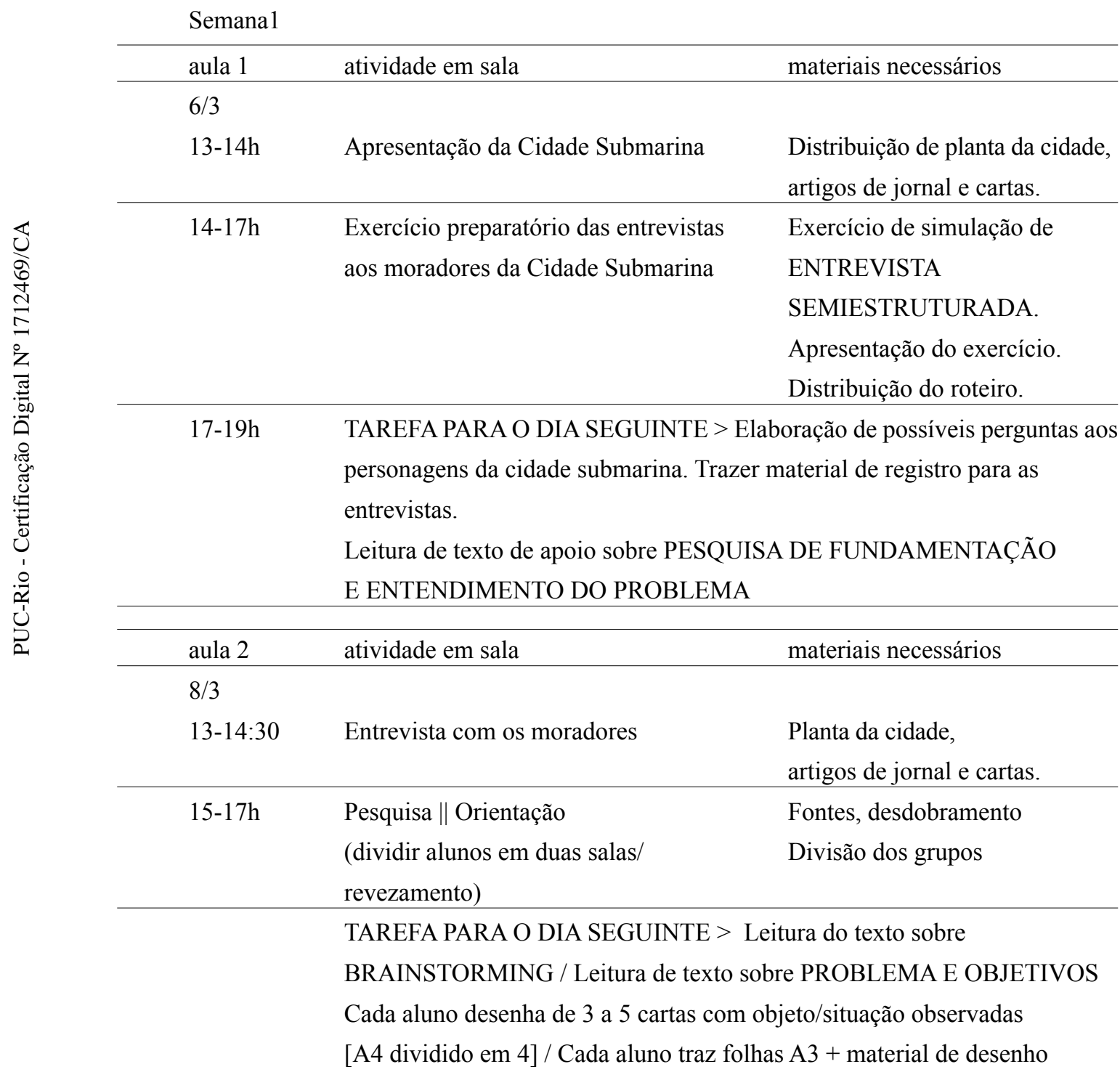

fig. 3.7 - Planejamento da Cidade Submarina. Fonte: acervo do autor. 
Semana2

\begin{tabular}{|c|c|c|}
\hline aula 3 & atividade em sala & materiais necessários \\
\hline \multicolumn{3}{|l|}{$6 / 3$} \\
\hline \multirow[t]{24}{*}{$13-17 \mathrm{~h}$} & Sorteio de cartas -30 & ANÁLOGOS E SIMILARES \\
\hline & & Presencial - apresentação \\
\hline & Geração de ideias (brainstorming) - 60' & preparatória para o exercício \\
\hline & [cada grupo gera no mínimo 3, porém & de brainstorming \\
\hline & dentro de 1 hora cada grupo pode gerar & \\
\hline & quantas forem possíveis] & Cartas VERBO = modificar, \\
\hline & São sorteadas sempre 1 carta & transformar, aprimorar, criar, \\
\hline & de cada categoria. & ressignificar, planejar, melhorar, \\
\hline & As 3 cartas deverão ser grampeadas & carta em branco. \\
\hline & a uma folha $\mathrm{A} 3$ e ao lado o grupo & \\
\hline & deverá construir uma frase problema & Cartas SITUAÇÃO PROBLEMA \\
\hline & de acordo com o kit de cartas. Nesta & transportes, produção de \\
\hline & mesma folha as ideias deverão & alimentos, socialização, \\
\hline & ser registradas por desenho. & moradia, purificação do ar, \\
\hline & & purificação da água, lixo, lazer, \\
\hline & Brainstorming cruzado $-5 \times 10^{\prime}$ & política de imigração, saúde \\
\hline & A folha original de cada grupo vai & pública, carta em branco. \\
\hline & circulando por outros grupos em & \\
\hline & sessões de 10’. Os grupos deverão & Cartas SIT. OBSERVADA \\
\hline & gerar ideias uns para os outros. & PRODUZIDAS PELOS \\
\hline & & ALUNOS \\
\hline & \multicolumn{2}{|l|}{ Escolha de alternativas possíveis que } \\
\hline & \multicolumn{2}{|c|}{ possam vir a ser adotadas como partido $-20^{\prime}$} \\
\hline & \multicolumn{2}{|c|}{ Palavras chave que deverão ser norteadoras da escolha do partido: } \\
\hline \multicolumn{3}{|c|}{ INOVADOR, CRIATIVO, ORIGINAL, INCOMUM, INUSITADO, ADEQUADO À CULTURA } \\
\hline \multicolumn{3}{|c|}{ LOCAL, IMPREVISTO, INESPERADO, SURPREENDENTE } \\
\hline
\end{tabular}

- Aprofundar o conhecimento sobre o problema de pesquisa;

- Gerar/aprimorar cerca de 10 ideias por grupo.

TAREFA PARA O DIA SEGUINTE > Trazer sucatas e materiais variados. MODELOS E PROTÓTIPOS - Leitura de texto de apoio ANÁLOGOS E SIMILARES - Leitura de texto de apoio

\begin{tabular}{lll}
\hline aula 4 & atividade em sala & materiais necessários \\
\hline $15 / 3$ & \\
$13-15 \mathrm{~h}$ & Construção de modelos em técnicas e materiais variados \\
\hline $15-17 \mathrm{~h}$ & Escolha do partido a ser desenvolvido \\
\hline
\end{tabular}

fig. 3.8 - Planejamento da Cidade Submarina (continuação). Fonte: acervo do autor. 


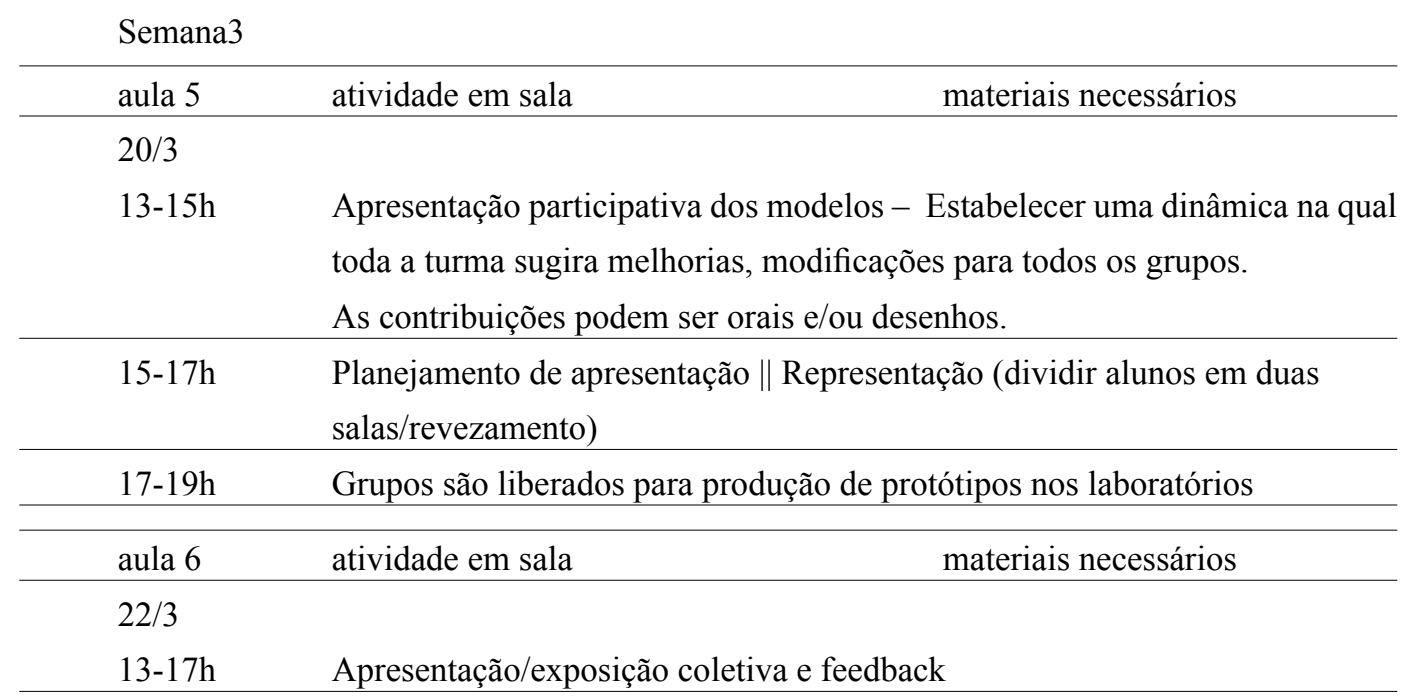

fig. 3.9 - Planejamento da Cidade Submarina (continuação). Fonte: acervo do autor.

\section{4 \\ Relatório diário 2018.1 - diário de bordo e reflexões}

(ou: como foi a navegação)

O exercício foi planejado para durar três semanas, com seis tempos de aula seguidos às terças e quatro tempos às quintas-feiras, passando por quatro etapas das cinco constantes na metodologia de projeto do Design Thinking: entender, interpretar, criar e prototipar. Cada dia do exercício compreendia atividades pré-aula, atividades em sala e atividades pós-aula, que atuavam como fio condutor e mantinham o envolvimento dos estudantes.

À medida que as turmas avançavam na execução do exercício projetual, recebiam informações teóricas sobre a etapa seguinte e eram capacitados ao seu desenvolvimento. Dessa forma, experimentamos a interdisciplinaridade no ensino simultâneo de Metodologia de Pesquisa e de Metodologia de Projeto. As aulas de Metodologia capacitaram os estudantes à imediata aplicação prática, contribuindo ao mesmo tempo para a fixação do conhecimento teórico e para o melhor desenvolvimento do projeto de Design.

\section{Briefing}

Todos os alunos ${ }^{3}$ foram reunidos para o briefing do exercício, que foi apresentado pela supervisora da disciplina como tendo sido uma demanda apresentada pelo Conselho de Anciãos da Cidade. O Conselho ouvira falar do curso de Design da PUC e queria que os estudantes fizessem uma imersão na Cidade Submarina

3 Projeto II tem seis turmas de 18 alunos, reunidas em cada sala duas a duas. Cada sala fica, assim, com dois professores de pauta. 
para desenvolverem projetos que pudessem ajudar a melhorar as novas situações que se apresentavam. Exibiu-se um vídeo onde um professor falava sobre projetos de Design especulativo. A partir daí o exercício teve início.

A primeira etapa, entender, ocupou o primeiro dia e a metade do segundo. Envolveu conhecer, pesquisar, reunir referências e entender o desafio.

Dia 1

No primeiro dia, após o briefing do projeto, todos tiveram uma aula sobre técnicas de entrevistas onde aprenderam sobre entrevistas estruturadas, semi estruturadas e não estruturadas e realizou-se uma dinâmica onde os alunos foram divididos em dois grupos grandes.

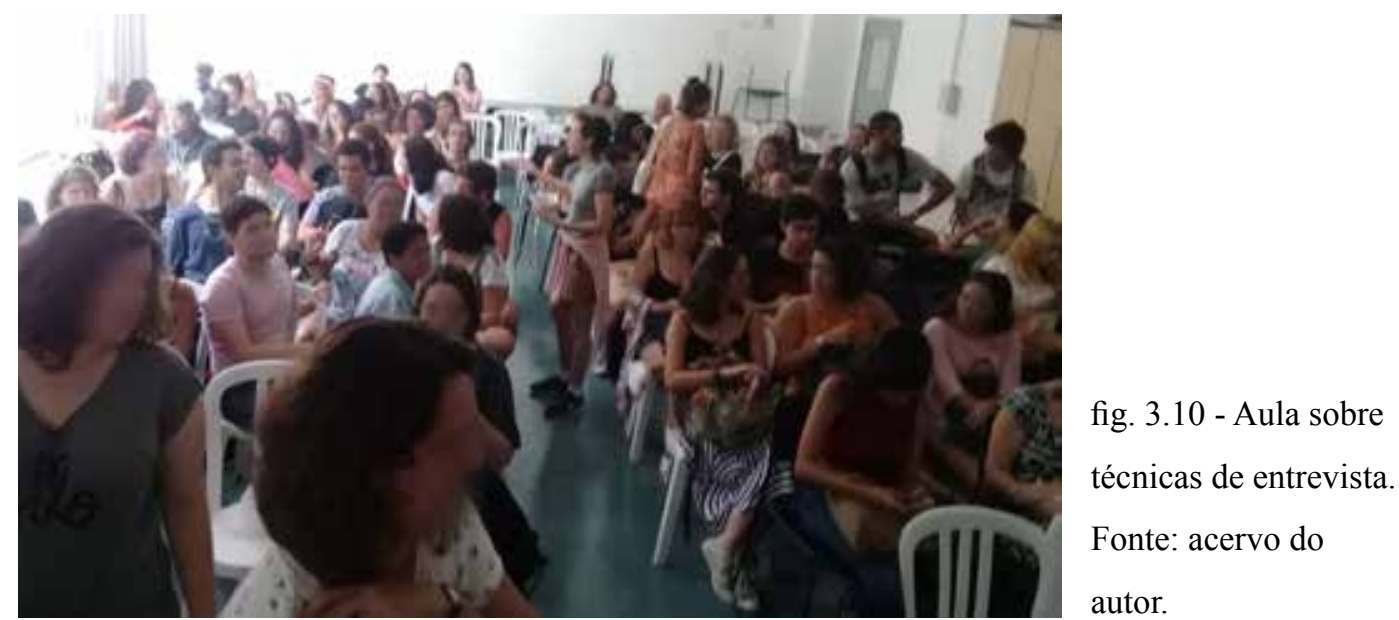

Cada grupão ficou em uma sala e os alunos foram divididos em seis grupos com cerca de sete participantes e um professor. A seguir, entrevistaram os professores, que precisaram responder de improviso, como se fossem brasileiros morando em Dubai.

Os professores deveriam assumir o papel de moradores de uma ilha localizada em Dubai e os pesquisadores deveriam saber porque eles haviam se mudado para lá, se sentiam falta do Brasil, como era viver no estrangeiro.

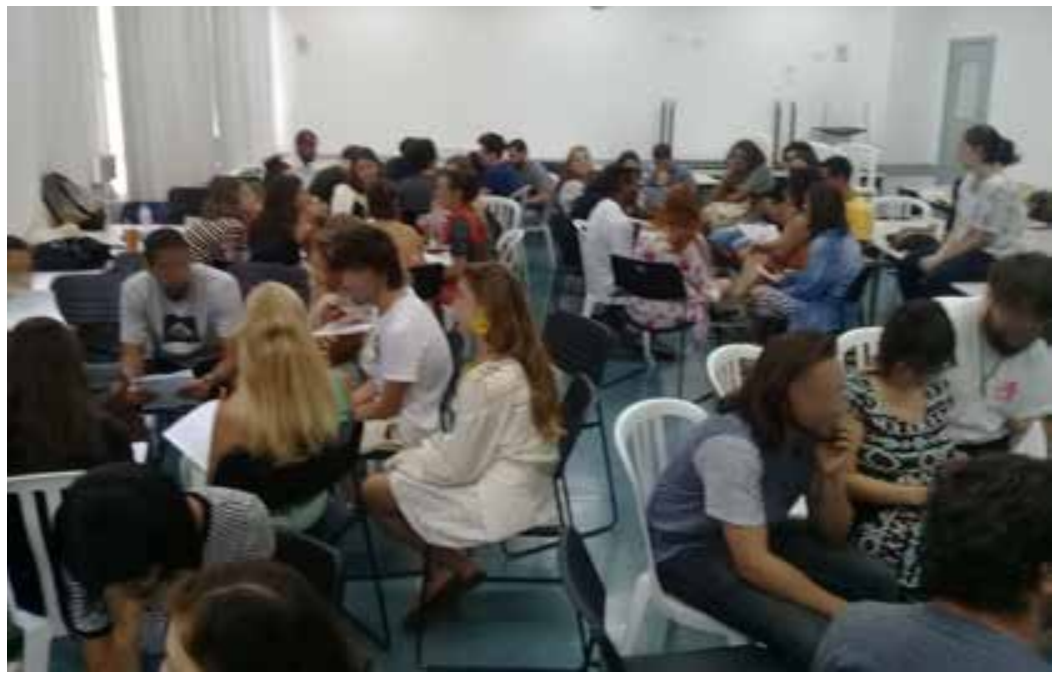

fig. 3.11 - Dinâmica de entrevistas: grupos praticam entrevistando professores. Fonte: acervo do autor. 
Essa dinâmica foi importante para a preparação tanto de alunos como dos professores. Os alunos perceberam a importância do planejamento para uma entrevista ser produtiva e os professores perceberam que eram capazes de improvisar, o que deu mais naturalidade aos personagens. Ao final da dinâmica, os alunos debateram o que tinham aprendido sobre entrevistas, e o que tinham considerado falho no processo. Os professores vieram à frente da sala e relataram suas impressões.

Segundo o relato dos professores, os alunos não estavam se aprofundando no que perguntavam, contentavam-se com respostas superficiais sem formularem novas perguntas para aprofundamento. Em alguns casos, sobretudo no grupo que entrevistou o monitor, Lucas, as perguntas foram sendo conduzidas a outros rumos, investigando questões relativas a procedimentos de imigração, política e mesmo religião, casos em que os entrevistadores fugiram completamente à pauta original, e ficaram sem respostas para ela. Tais questões em alguns casos eram muito abertas, em outros casos abordavam tópicos que o morador certamente não teria como conhecer e no máximo daria uma impressão pessoal (como, por exemplo, perguntas sobre os planos futuros do país com relação à imigração). Algumas perguntas eram formuladas de forma direta demais, e quando o tema era delicado, alguns entrevistados sentiram-se desconfortáveis e preferiram não responder, ou deram respostas evasivas. Poucos alunos registraram a entrevista, nenhum deles tendo gravado e somente um ou dois em quatro dos seis grupos tendo anotado o que ia sendo respondido.

Com base nesses relatos, concluímos a aula pedindo aos estudantes que lessem toda a documentação fornecida sobre a Cidade Submarina, identificassem lacunas ou pontos em que gostariam de se aprofundar e que planejassem perguntas que fariam aos membros da administração local. Recomendamos que escolhessem personagens de seu interesse e direcionassem suas pesquisas a eles, pois não haveria tempo para conversarem com todos. Pedimos que escrevessem pautas para suas entrevistas e que procurassem obter informações em profundidade, evitando abordar questões polêmicas de forma desafiadora, mas abordá-las de forma indireta, buscando obter as informações desejadas. As entrevistas deveriam ser registradas, em anotações ou gravações.

Todos os professores disseram que a dinâmica fora muito interessante, cada um criou um personagem para si, uma realidade paralela e que à medida que o exercício ia acontecendo, foram se sentindo à vontade, construindo seus personagens. Tinham se divertido ao longo dos 25 minutos de duração, o tempo havia passado rápido, sentiram-se quase participando de um improviso de teatro.

Para a Cidade Submarina, isso funcionou como um treinamento dos professores, que na aula seguinte seriam entrevistados no papel de gestores da Cidade. Dessa forma, a dinâmica de entrevistas cumpriu uma dupla função: preparar os alunos, com base na teoria e na prática, e treinar os professores. 
Como tarefa para a aula seguinte, deveriam estudar os textos e formular perguntas para fazerem aos moradores da Cidade.

\section{DIA 2}

O segundo dia começou pelas entrevistas, com os professores distribuídos em duas salas e os estudantes circulando livremente, entrevistando aqueles que gerenciavam as áreas que mais lhes interessavam, registrando o que levantavam de informações.

Participaram 14 professores, cada um assumindo um papel ligado à administração da Cidade (relação de papéis nos anexos). Fui o ancião, um dos membros do conselho de cientistas que havia fundado o experimento. Coube a mim esse papel pois, como planejador do exercício, poderia ser consultado pelos outros professores caso surgisse alguma pergunta de maior complexidade para a qual não conseguissem encontrar respostas.

Cabe dizer que mais da metade dos professores estava caracterizado como seu personagem, utilizando óculos, perucas e outros acessórios. Esse detalhe foi um toque de humor, criado a partir da teoria da incongruência. Foi um ponto importante apontado tanto por professores como por alunos entrevistados, contribuiu para fazer com que os alunos entrassem mesmo na ficção.

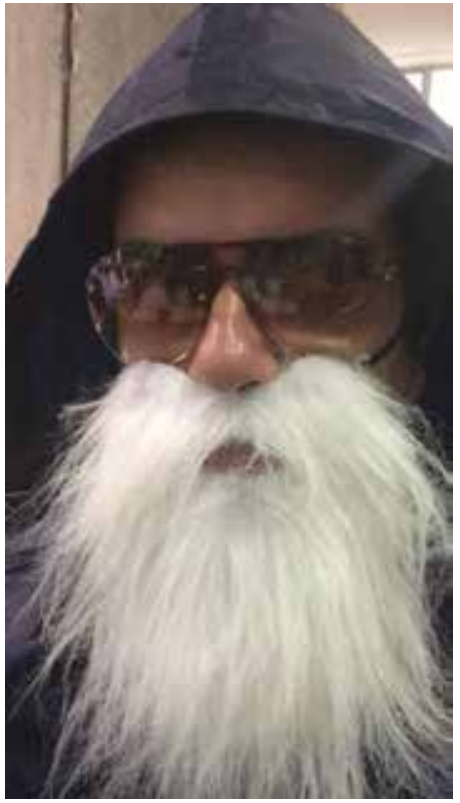

fig. 3.12 - Ancião: prof. André Beltrão. Fonte: acervo do autor.

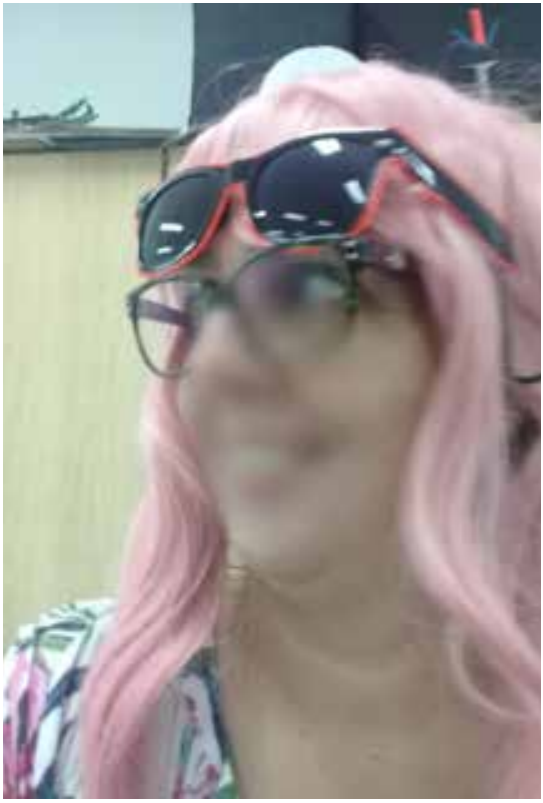

fig. 3.13 - Gerente de educação: prof. Flávia Nizia.

Fonte: acervo do autor.

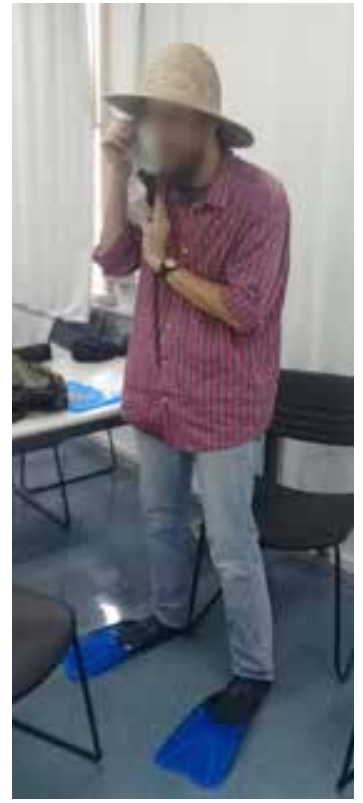

fig. 3.14 - Gerente de agricultura e pecuária: prof. Daniel Malaguti. Fonte: acervo do autor.

As perguntas foram em grande parte relacionadas ao dia a dia da Cidade, tornando-se mais específicas com relação aos temas que pareceram mais problemáticos aos estudantes: acolhimento dos refugiados, trabalho, relações sociais, lazer, saúde, moradia, educação, produção de alimentos e de oxigênio. 
Como eu tinha já realizado o experimento no semestre anterior, estava mais preparado para responder de improviso pois tinha pesquisado tanto informações técnicas como experimentos análogos reais. Os outros professores não tinham feito essa pesquisa de aprofundamento, porém como também tinham vivenciado o semestre anterior estavam à vontade $\mathrm{e}$ as entrevistas transcorreram com bastante fluidez.

Tal improviso também estava nos planos e contribuiu para o estranhamento das respostads dadas pelos moradores, pois resgatamos algumas perguntas que tinham surgido na primeira edição e planejamos respostas desconcertantes para elas, como por exemplo a pergunta "o que vocês fazem com os mortos?" e a resposta planejada: "jogamos na usina de reciclagem" ou a pergunta "onde os estrangeiros estão morando?" e a resposta: "no meu armário". Segundo Santos (2009), essa incompatibilidade das respostas com o padrão normal de expectativa torna a entrevista incongruente, e o estranhamento que vem dessa incongruência torna a entrevista mais divertida e imersiva.
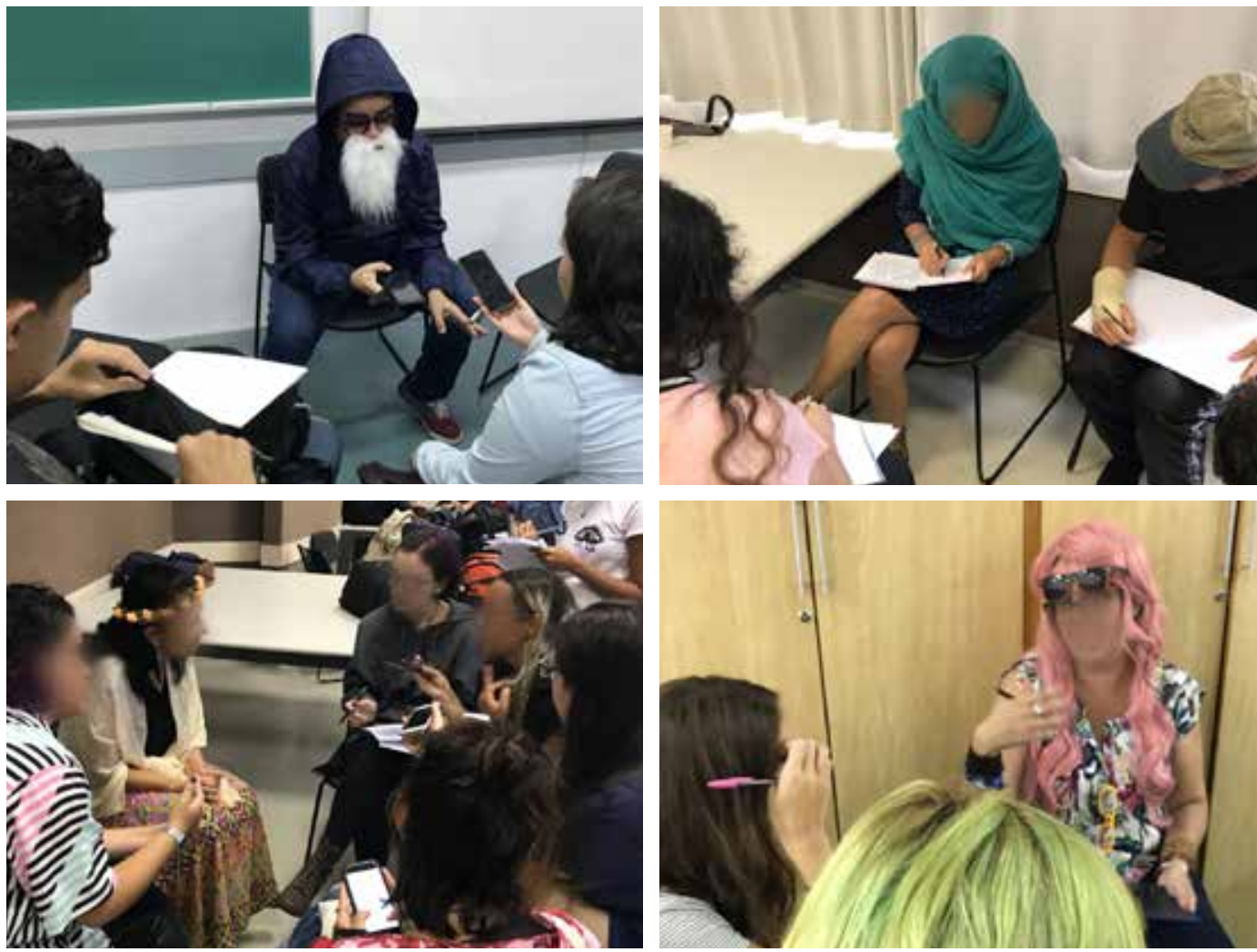

fig. 3.15 - Moradores da Cidade sendo entrevistados: ancião, mulher misteriosa, gerente do Domo Holístico, gerente de Educação. Fonte: acervo do autor.

Após as entrevistas, de volta às salas de aula de Projeto, foi hora de interpretar os achados de pesquisa. Perguntados sobre que situações-problema ou oportunidades de projeto haviam encontrado na Cidade, criticaram a discordância entre o que havia sido dito pelos moradores.

Como essa discordância era prevista e planejada, foi o momento certo para uma pequena aula sobre fontes de pesquisa, onde pedimos que filtrassem as infor- 
mações avaliando qual gerente era mais habilitado a responder sobre cada tópico, considerando os diferentes referenciais. Enfatizamos que nas situações reais tais discordâncias também ocorrem, pois cada um tem um ponto de vista particular.

Os alunos foram relatando problemas que haviam identificado, que foram escritos no quadro pelos professores. Alguns foram agrupados por proximidade temática.

Listadas as situações-problema, fizemos um debate sobre situações análogas e similares, pedindo que pensassem em exemplos para cada item. Em seguida, propusemos duas tarefas para casa: uma pesquisa sobre situações análogas e similares às situações-problema e a produção de desenhos de dez objetos ou situações que imaginassem haver na Cidade Submarina.

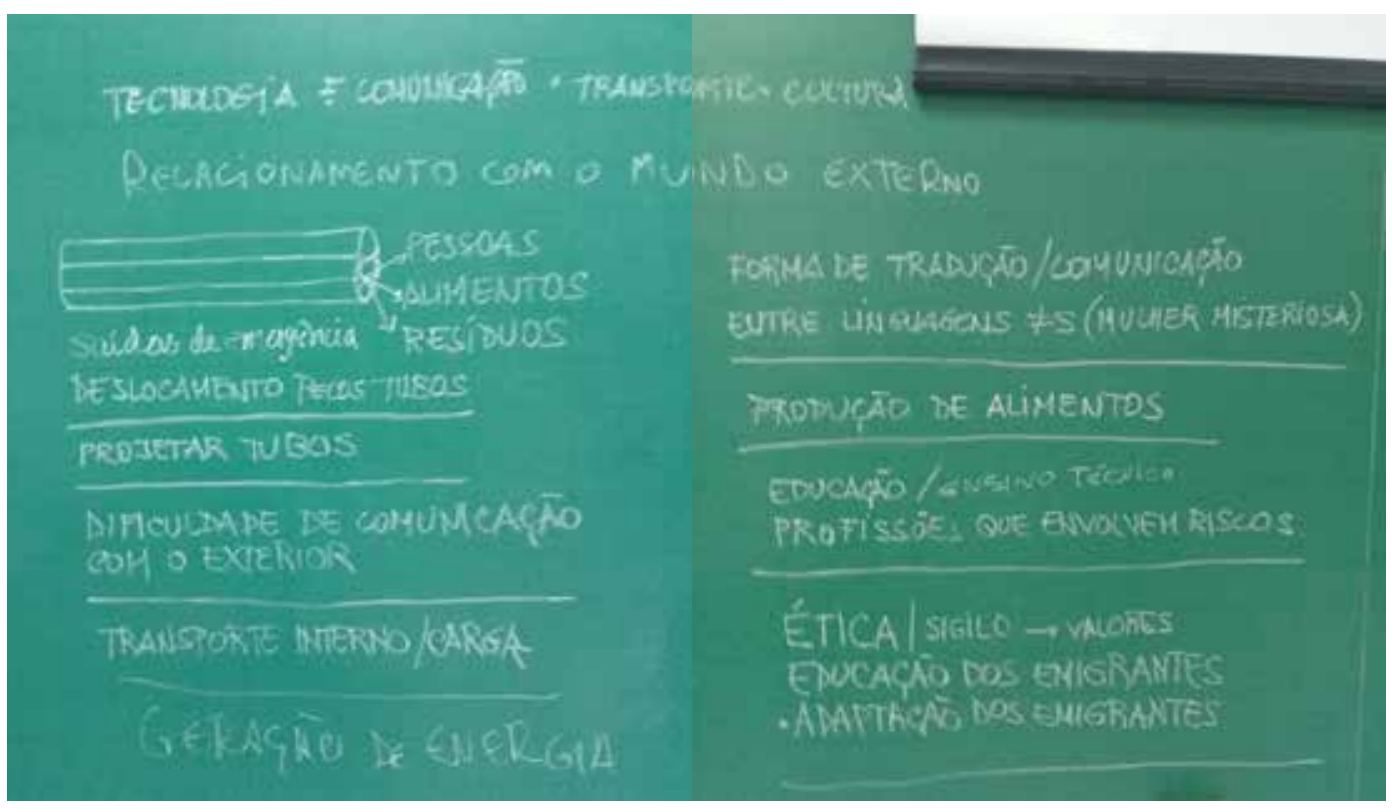

fig. 3.16 - Situações-problema que emergiram das entrevistas. Fonte: acervo do autor.

\section{DIA 3}

O terceiro dia foi dedicado a criar. Iniciamos explicando o que é uma geração de ideias e falando sobre diferentes métodos de brainstorming. Dividimos a turma em grupos e iniciamos um processo que batizamos de brainstorming cruzado, em que todos geravam ideias para todos.

Utilizamos três baralhos de cartas especialmente preparados para a atividade: o primeiro, continha cartas com os verbos "modificar", "aprimorar", "ressignificar", "melhorar", "transformar", "criar" ou "planejar"; no segundo, estavam escritas as situações-problema observadas pela turma na aula anterior e, no terceiro, estavam os desenhos trazidos pelos estudantes da tarefa de casa.

Cada grupo sorteou dois conjuntos de cartas contendo uma carta de cada baralho e cada conjunto foi grampeado no topo de uma folha A3 formando uma 
sequência lógica, como por exemplo: "planejar formas de registrar a história para formar uma literatura da cidade Submarina".

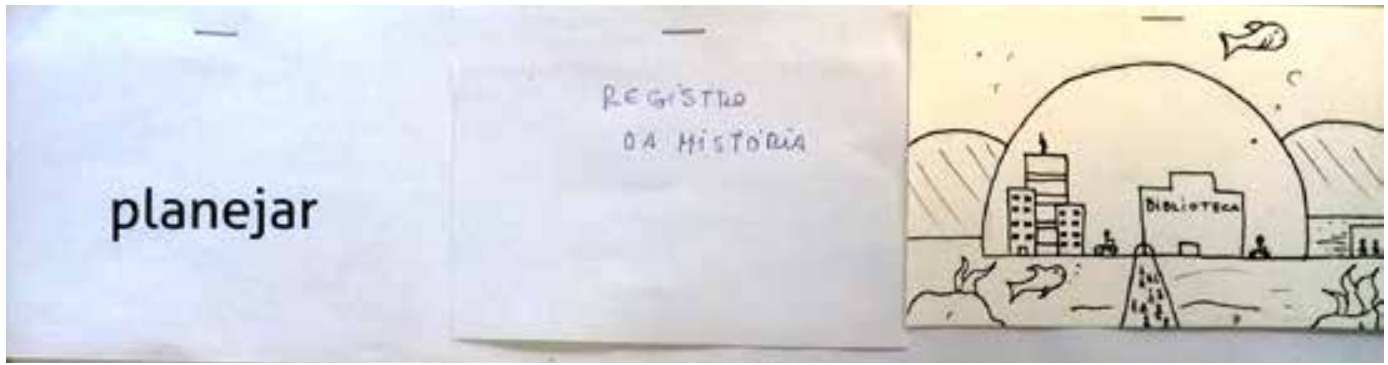

fig. 3.17 - Exemplo de sequência de cartas sorteadas. Fonte: acervo do autor.

A dinâmica de geração de ideias foi realizada em sessões de dez minutos cada, nas quais cada grupo se dedicou a desenhar soluções para seus dois conjuntos de cartas. Em seguida, as folhas desenhadas eram passadas para o grupo sentado do lado direito e no mesmo instante eram recebidas as folhas do grupo que estava sentado do lado esquerdo e assim sucessivamente, até que todos os grupos tivessem gerado ideias nas folhas de todos os grupos.
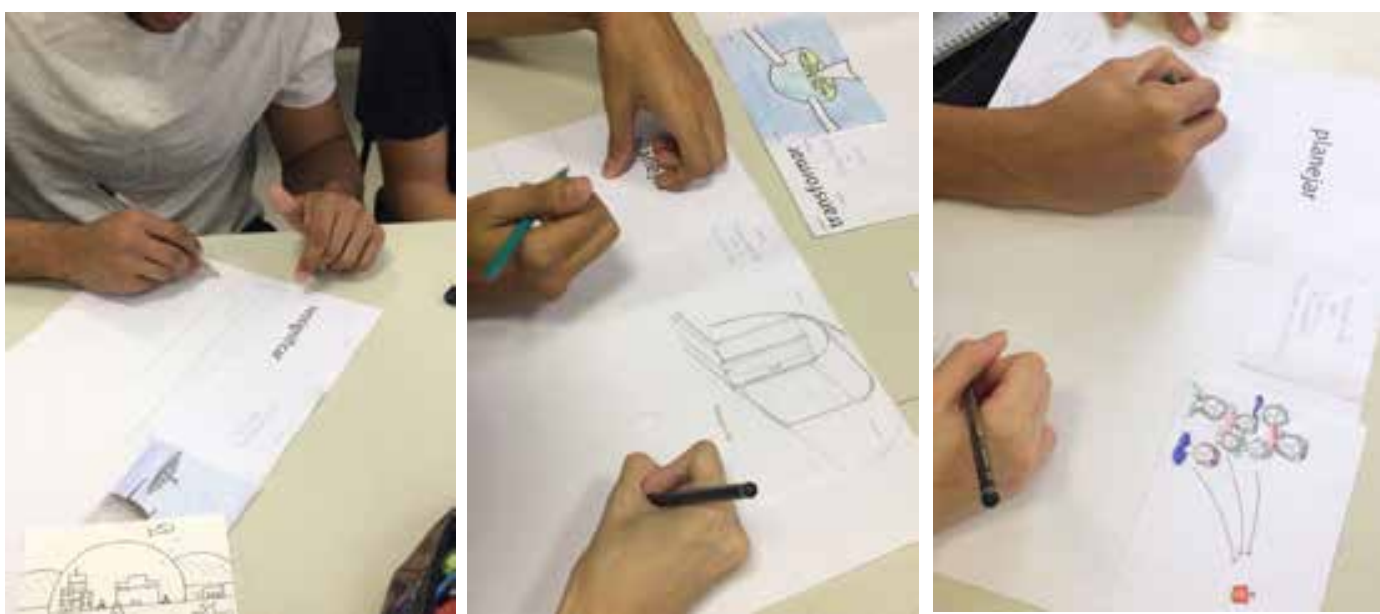

fig. 3.18 - Brainstorm cruzado: geração colaborativa de ideias. Fonte: acervo do autor.

Após a sessão de desenhos pedimos aos alunos que analisassem as sugestões recebidas e escolhessem uma ideia para desenvolver. Como tarefa de pesquisa, em casa deveriam pensar em alternativas para suas ideias e precisariam trazer materiais e sucatas para a aula seguinte.
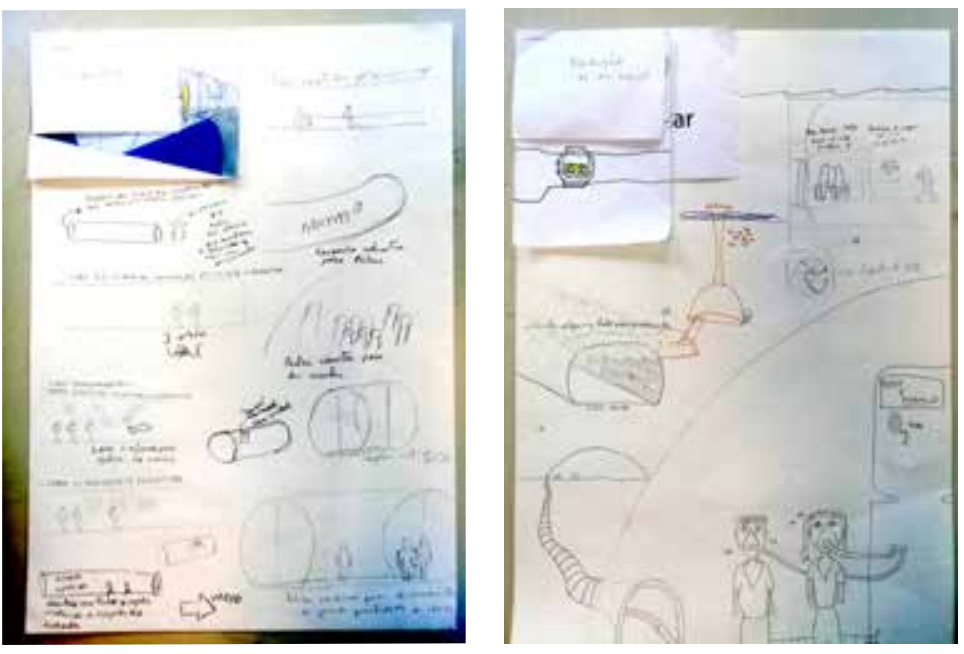

fig. 3.19 - Brainstorm cruzado: exemplos.

Fonte: acervo do autor. 

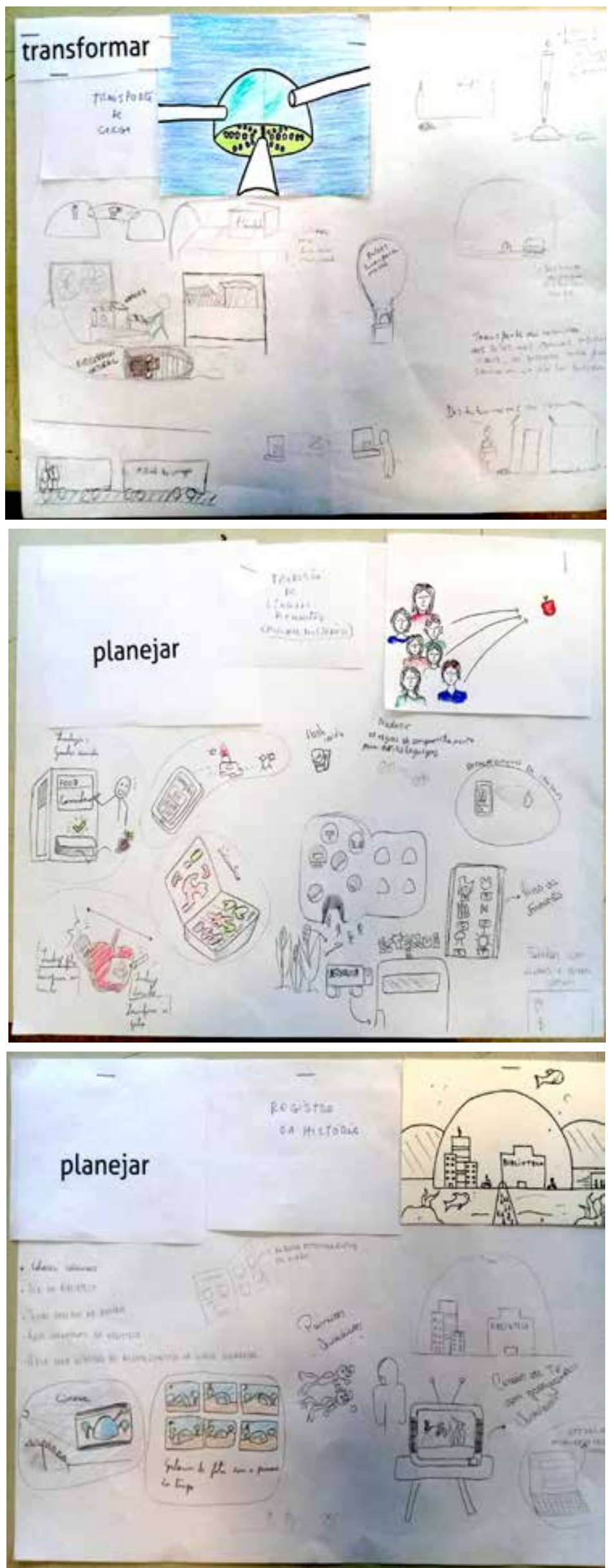

fig. 3.20 - Brainstorm cruzado: exemplos.

Fonte: acervo do autor. 


\section{DIA 4}

$\mathrm{Na}$ aula quatro tivemos duas atividades: desenvolvimento de ideias e construção de primeiros modelos.

Primeiro, os estudantes discutiram em grupo seus achados de pesquisa e, partindo das folhas com ideias da aula anterior, esboçaram o desenvolvimento de algumas possibilidades de soluções.

Em seguida, fizeram objetos bem simples, com sucatas, ilustrando as principais ideias para posterior avaliação pelos professores sobre as possibilidades de desenvolvimento.

Em cada turma os professores de pauta foram atendendo os grupos e orientando a atividade. No final, foi escolhido um partido ou caminho de solução para ser construído em casa de forma menos precária, como uma espécie de modelo, que deveria ser trazido na aula seguinte.
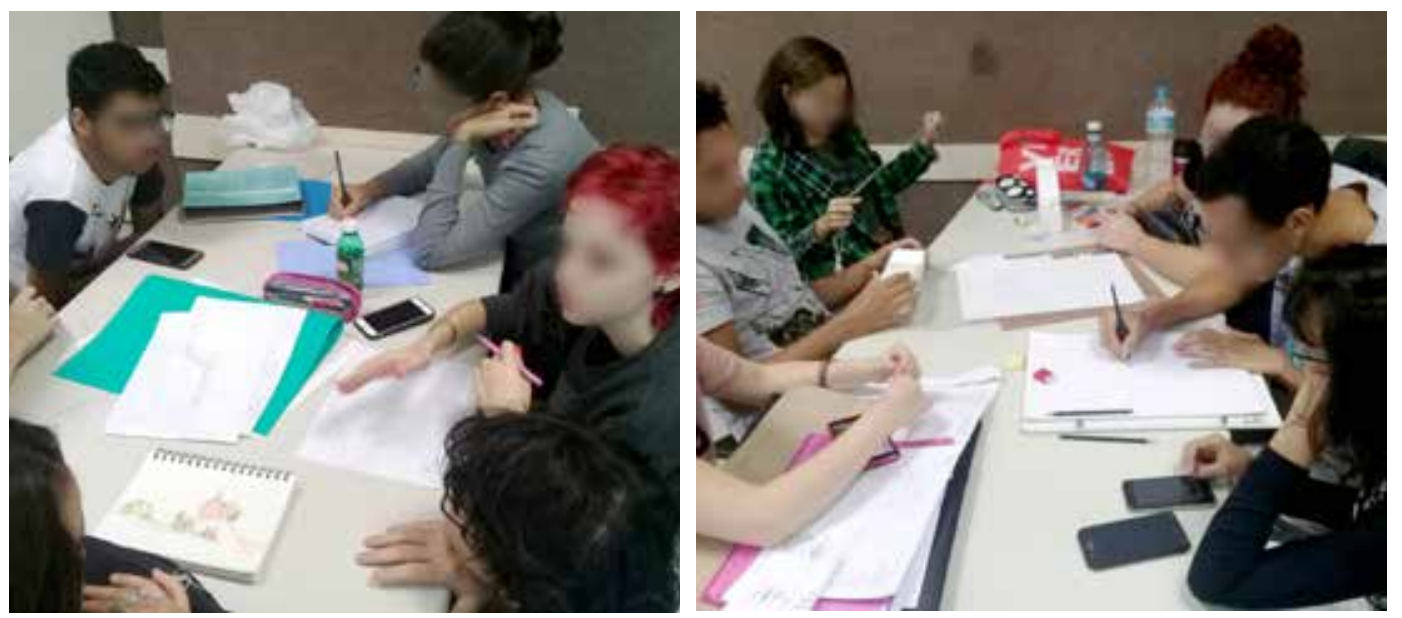

fig. 3.21- desenvolvimento de ideias e esboços. Fonte: acervo do autor.

Os grupos tinham muitos pontos de partida possíveis pois as folhas de ideias geradas na aula anterior eram muito ricas em opções variadas. Depois de cerca de uma hora de trabalho, pedimos aos grupos que apresentassem à turma os caminhos em que iriam trabalhar.

Cada apresentação foi de cinco minutos e cada grupo deveria dizer sua frase (exemplo: transformar o transporte de cargas através dos tubos) e em seguida as principais ideias que tivessem surgido. Após cada apresentação, os demais alunos da turma puderam fazer perguntas e dar sugestões.

Terminadas as apresentações, sugerimos que recolhessem nos laboratórios de Design restos de materiais para que pudessem montar em sala modelos tridimensionais, que facilitariam a visualização das ideias escolhidas.

Alguns alunos já tinham trazido papelão, cola, isopor. Enquanto parte dos membros de cada grupo ficou elaborando as ideias escolhidas e planejando os modelos, outros desceram rapidamente para recolher os demais materiais necessários. 
A montagem desses primeiros modelos serviu para que pudessem visualizar a operacionalidade de suas ideias, e, a partir do modelo, para que pudessem elaborar mais detalhadamente seus componentes e funcionalidades.
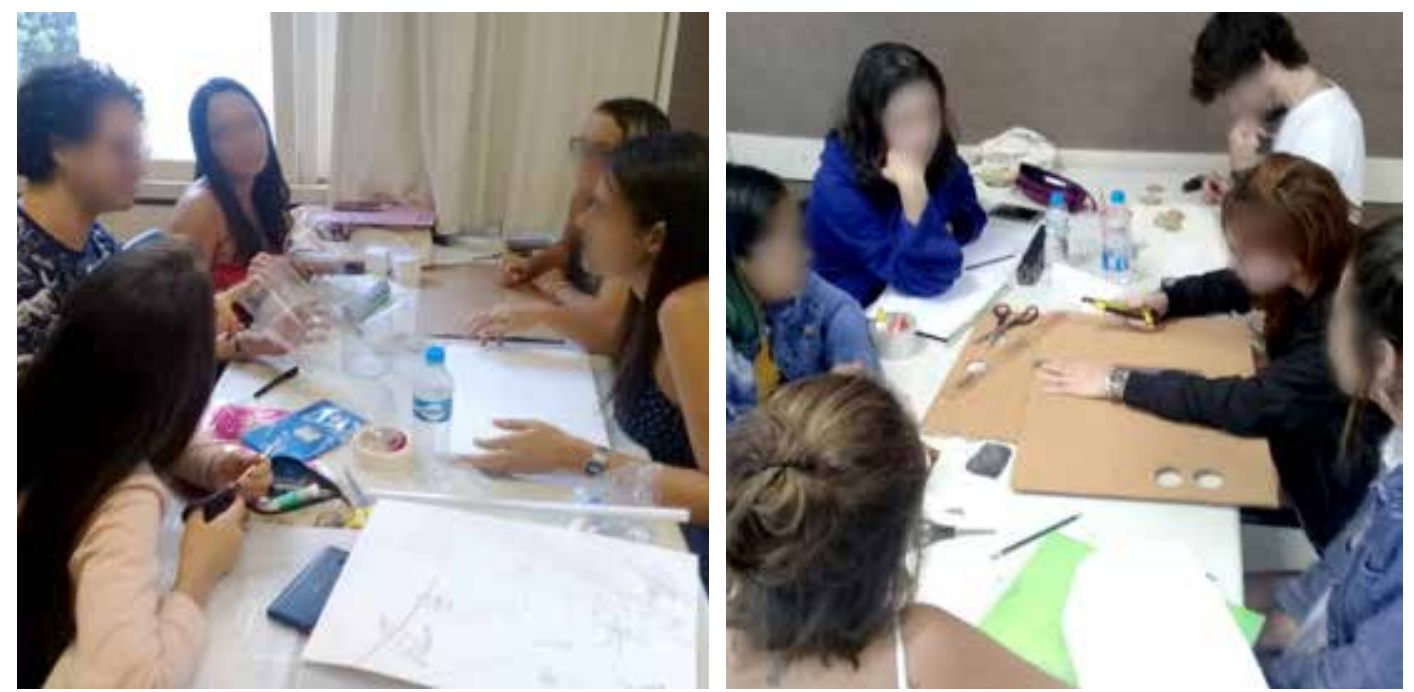

fig. 3.22 - planejando os modelos e, simultaneamente, pensando desenvolvendo ideias.

Fonte: acervo do autor.
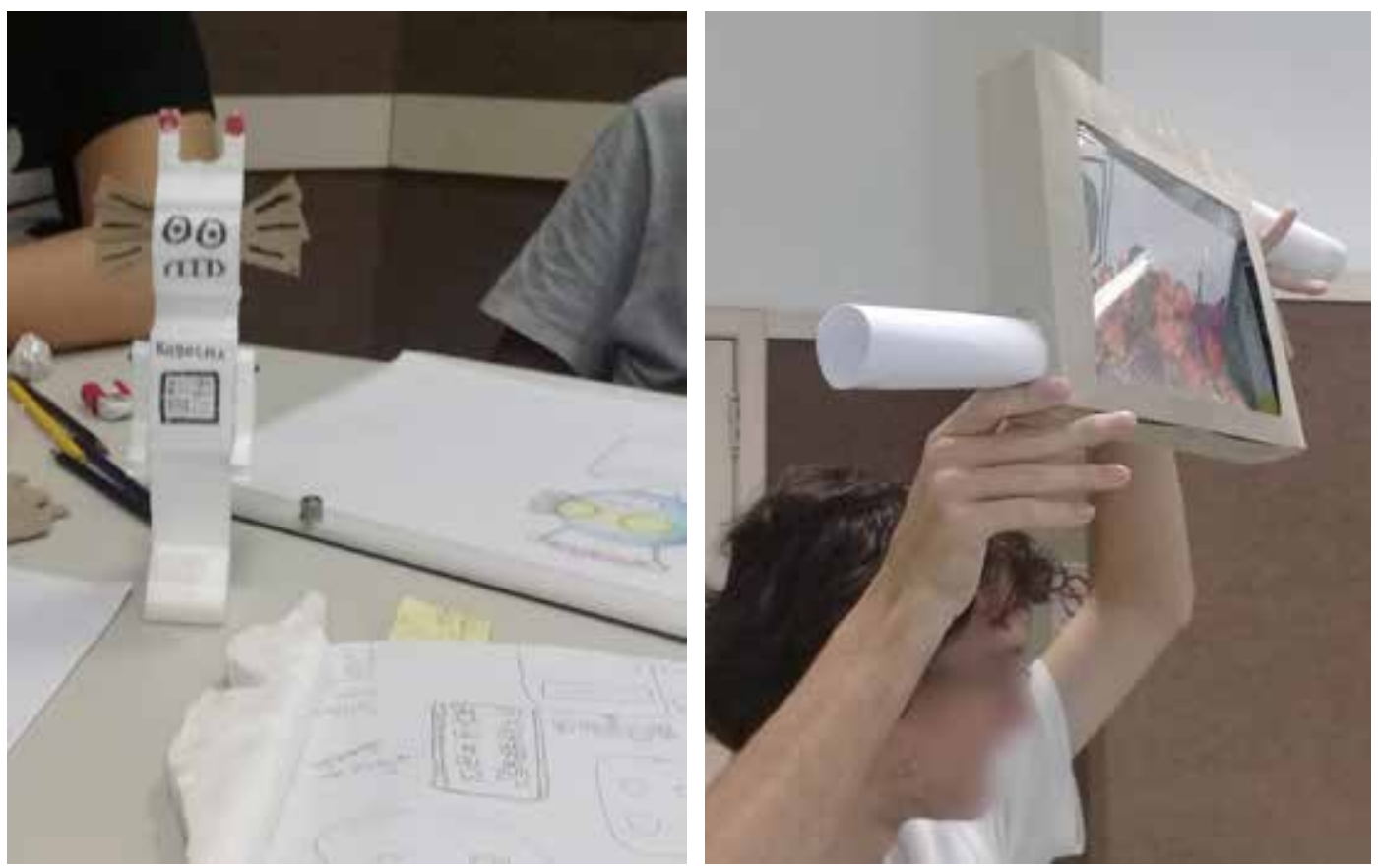

fig. 3.23 - primeiros modelos. Fonte: acervo do autor.

Enquanto os grupos montavam os modelos, os professores e monitores circulavam pela sala acompanhando o que estava sendo feito. Perguntávamos em cada grupo, a todo instante, como imaginavam que seria o funcionamento, e a partir das explicações deles, provocávamos mais reflexão perguntando sobre alguns pontos que não haviam pensado, o que levava os grupos à reflexão e aprimoramento imediato. Aos poucos, percebemos que esse processo começou a ocorrer naturalmente, estimulado pelos membros dos grupos. 
No final da aula, pedimos que cada grupo apresentasse novamente em poucos minutos as ideias em que estavam trabalhando. Os grupos apresentaram seus modelos e explicaram o funcionamento, e quase sempre o modelo apresentado era uma nova ideia resultante da união de duas ou mais ideias da fase anterior. A partir dessa apresentação, cada grupo tinha claramente um caminho de desenvolvimento adotado e a tarefa para a aula seguinte seria montar um modelo aprimorado.

\section{DIA 5}

$\mathrm{Na}$ quinta aula organizamos as cadeiras ao redor da sala, dispostas em roda, de modo que cada um pudesse ver todos.

Pedimos aos alunos que apresentassem sua situação-problema, já redefinida, em uma frase e a ideia, elaborada em seu contexto e relevância.

Por exemplo, a combinação que havia surgido no sorteio do brainstorm, "transformar o transporte de cargas através dos tubos" deu origem a "sistema de esteiras para transporte de cargas e resíduos" e o grupo explicou que seu projeto aproveitaria a rede de tubos que interligava os domos para realizar o transporte de cargas a partir dos armazéns de abastecimento e do porto de entrada e ao mesmo tempo para a remoção dos resíduos dos domos para a usina de tratamento de esgotos e resíduos. Para isso, criariam um sistema de esteiras sob o piso e tais esteiras seriam ativadas mecanicamente através de um sistema de captação da energia do movimento de pessoas e veículos sobre o piso.

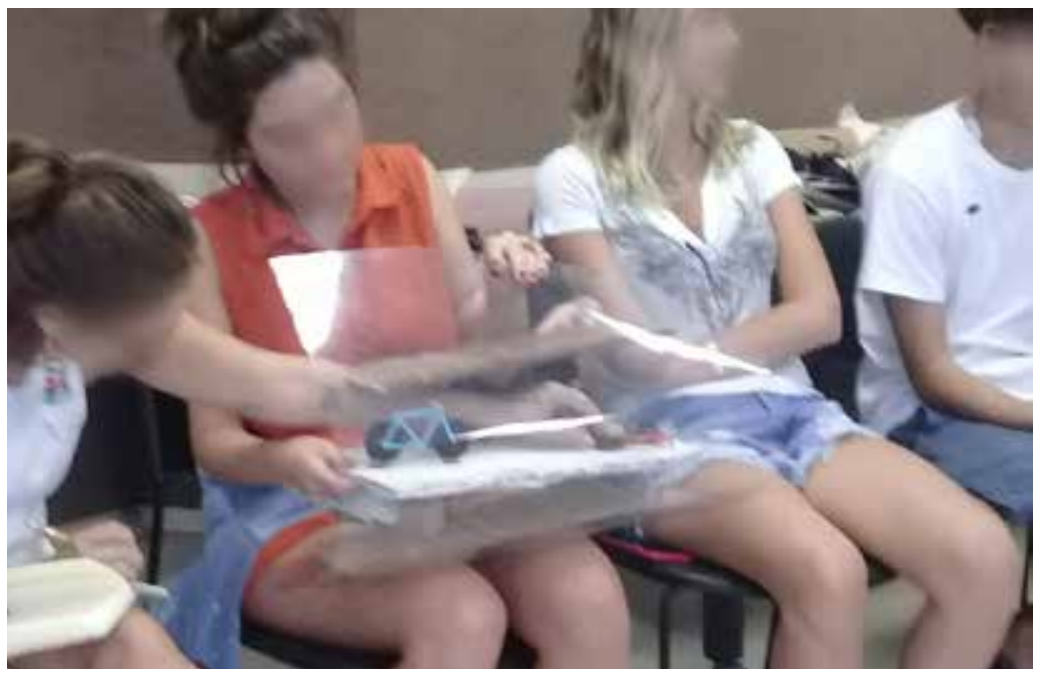

fig. 3.24 - apresentação do modelo de esteiras de transporte acionadas pelo movimento de veículos e pedestres no piso de trânsito.

Fonte: acervo do autor.

Todos mostraram a situação-problema e a solução adotada através dos modelos feitos com sucata em uma apresentação oral. Alguns grupos prepararam cartazes, mesmo sem que isso tivesse sido solicitado, o que foi ótimo pois pudemos falar um pouco sobre materiais de suporte a apresentações e sugerir mudanças e correções. As apresentações foram participativas e longas, ocupando a aula inteira. 

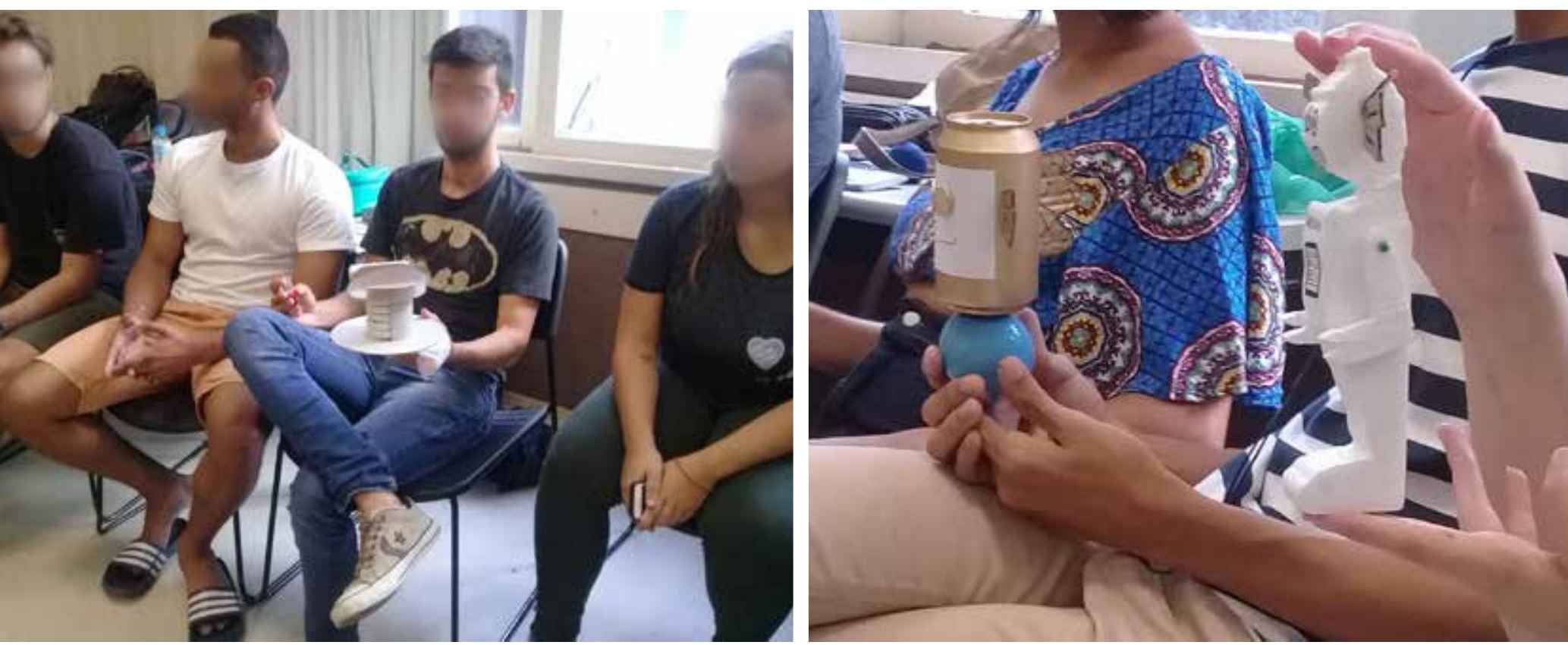

fig. 3.25 - apresentação participativa de modelos. À esquerda: cápsula de evacuação de emergência. À direita, os dois primeiros modelos do Robolha. Fonte: acervo do autor.

Como na aula anterior todos tinham conhecido os projetos, sentiram-se à vontade para comentar o aperfeiçoamento e para sugerir detalhes.

Tal participação foi intensa e produziu ótimos insights aos grupos, e surgiu algo inesperado e ótimo: os projetos começaram a se integrar e conectar, criando sistemas de soluções dentro da turma. Essa sistematização construiu-se voluntariamente em plenária, à medida que os modelos iam sendo apresentados.

Um dos projetos em que ocorreu a sistematização foi o Robolha: um pequeno robô flutuante e voador, podendo assim se deslocar na água e no ar. Tinha surgido a partir da frase "melhorar a comunicação através das pessoas". O Robolha teria como principal atividade informar os moradores da Cidade Submarina sobre qualquer coisa que quisessem saber, como por exemplo a programação dos TechTubes (projeto de outro grupo) ou sobre a localização de cada parte da Cidade. Também podia traduzir línguas estrangeiras e desenhos. Em caso de emergência, a Cidade Submarina teria um protocolo de evacuação em mini-cápsulas (projeto de outro grupo) e os Robolhas ficariam emitindo luzes vermelhas e orientando os moradores quanto aos procedimentos de emergência.

No exemplo citado, o projeto Robolha integrou-se aos projetos de dois outros grupos, criando uma solução sistêmica, o que não havia ocorrido na primeira aplicação do exercício. O sistema de evacuação de emergência da cidade, por sua vez, integrou-se ao Robolha e a outro projeto e quase todos, de certo modo, ficaram interligados.

Creio que isso ocorreu pela sequência de apresentações participativas em que, seguros de que dar sugestões não prejudicaria os colegas, criou-se um clima colaborativo entre os estudantes. 
Após as apresentações, os professores fizeram acompanhamento do desenvolvimento dos cartazes e aperfeiçoamento dos modelos a partir do que havia sido sugerido. Todos saíram alegres e empolgados e foram para os laboratórios para criar as apresentações e melhorar os modelos no tempo que restava.
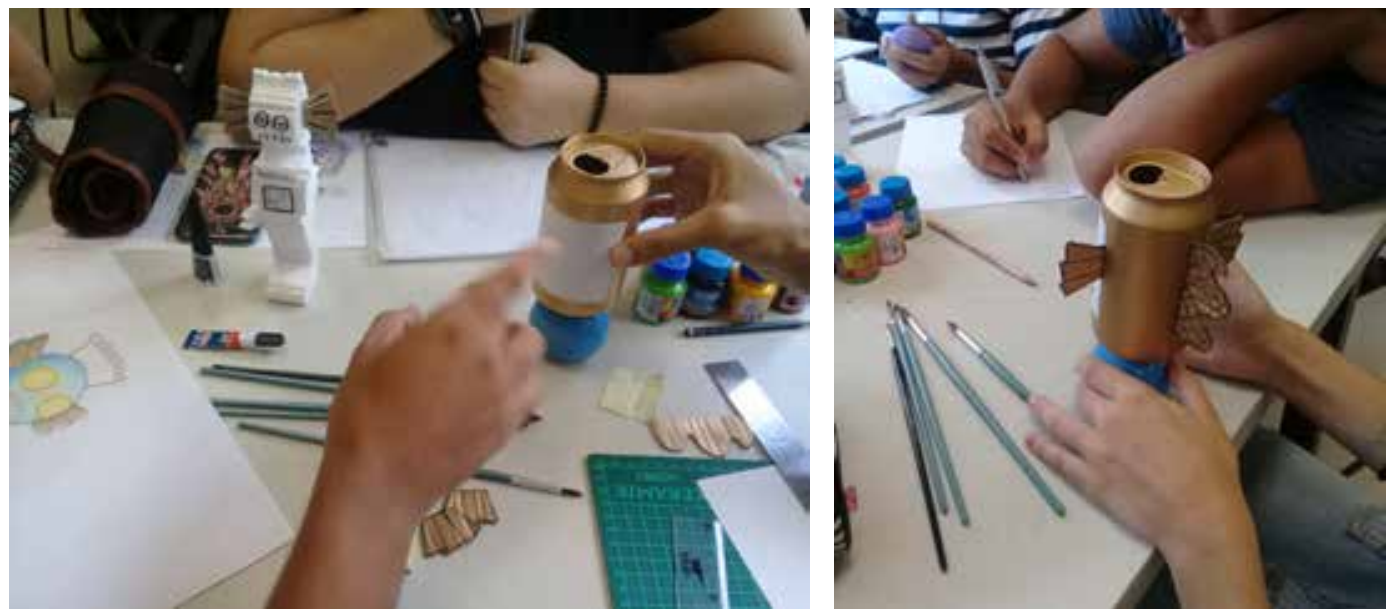

fig. 3.26 - desenvolvimento do modelo: Robolha. Fonte: acervo do autor.
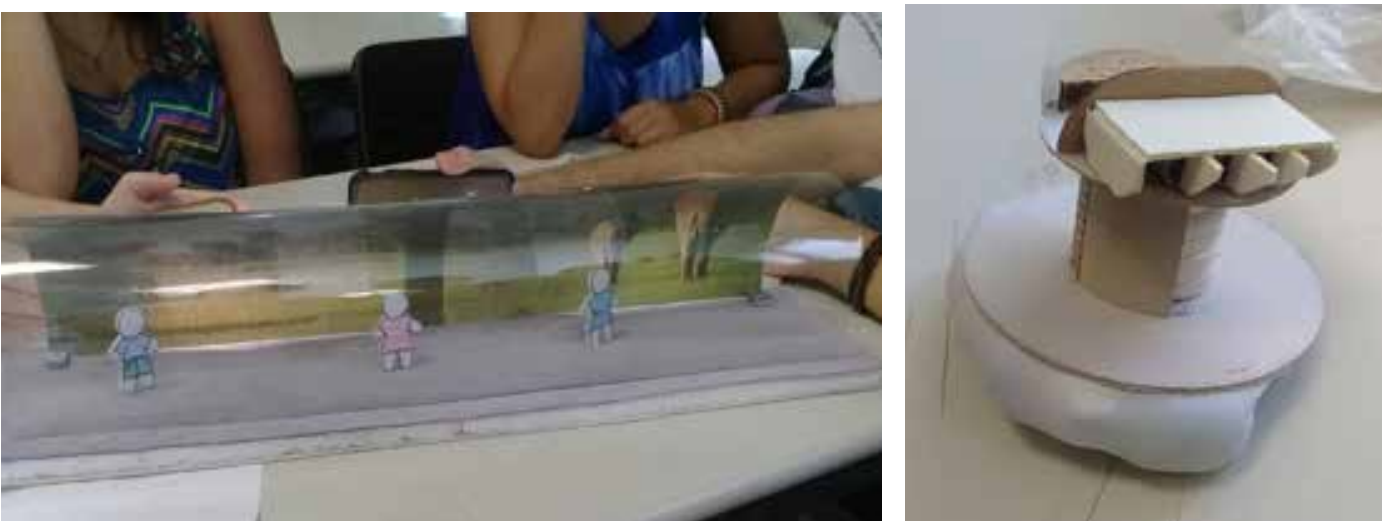

fig. 3.27 - primeiros modelos: Techtubo (esquerda) e cápsula de evacuação (direita).

Fonte: acervo do autor.
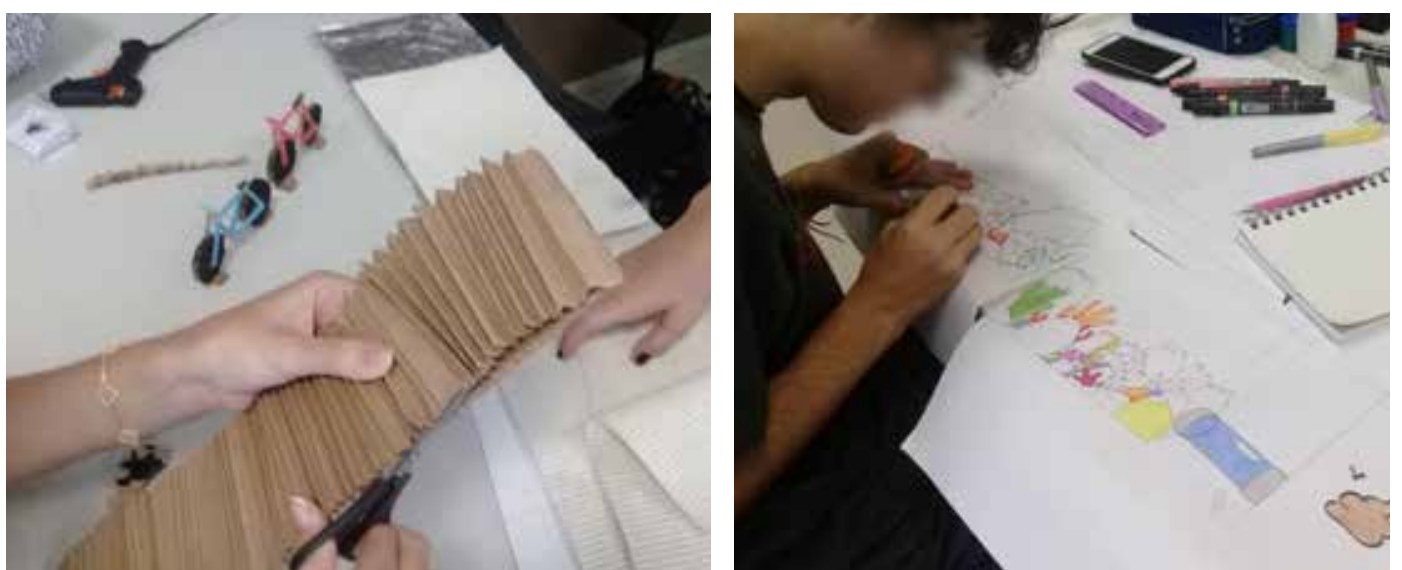

fig. 3.28 - desenvolvimento do modelos: sistema de transporte de cargas e resíduos (esquerda) e sistema de purificação de resíduos e esgotos (direita). Fonte: acervo do autor. 


\section{DIA 6}

$\mathrm{Na}$ sexta aula as turmas apresentaram seus modelos e cartazes. Dois professores $^{4}$ não quiseram participar da apresentação conjunta, assim quatro das seis turmas reuniram-se para a apresentação final. Essa apresentação conjunta foi importantíssima para que os estudantes de uma turma conhecessem os trabalhos dos colegas, que estavam vendo pela primeira vez.

De todo modo, os resultados de todos os exercícios projetuais foram compartilhados entre todas a turmas da disciplina pelo driver compartilhado do Google classroom, ambiente de ensino online, possibilitando que os estudantes conhecessem as soluções propostas por outros colegas.
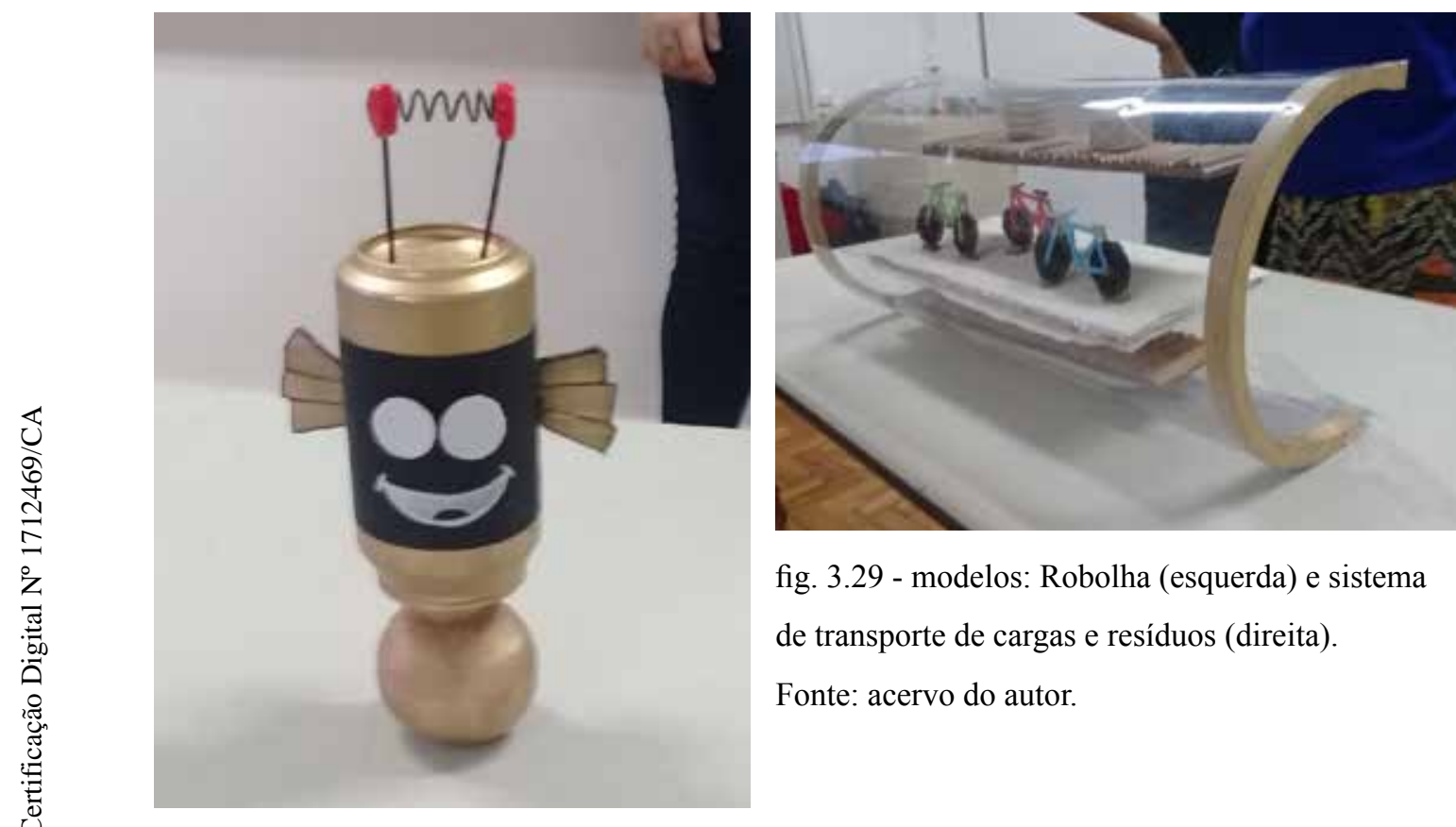

fig. 3.29 - modelos: Robolha (esquerda) e sistema de transporte de cargas e resíduos (direita).

Fonte: acervo do autor.
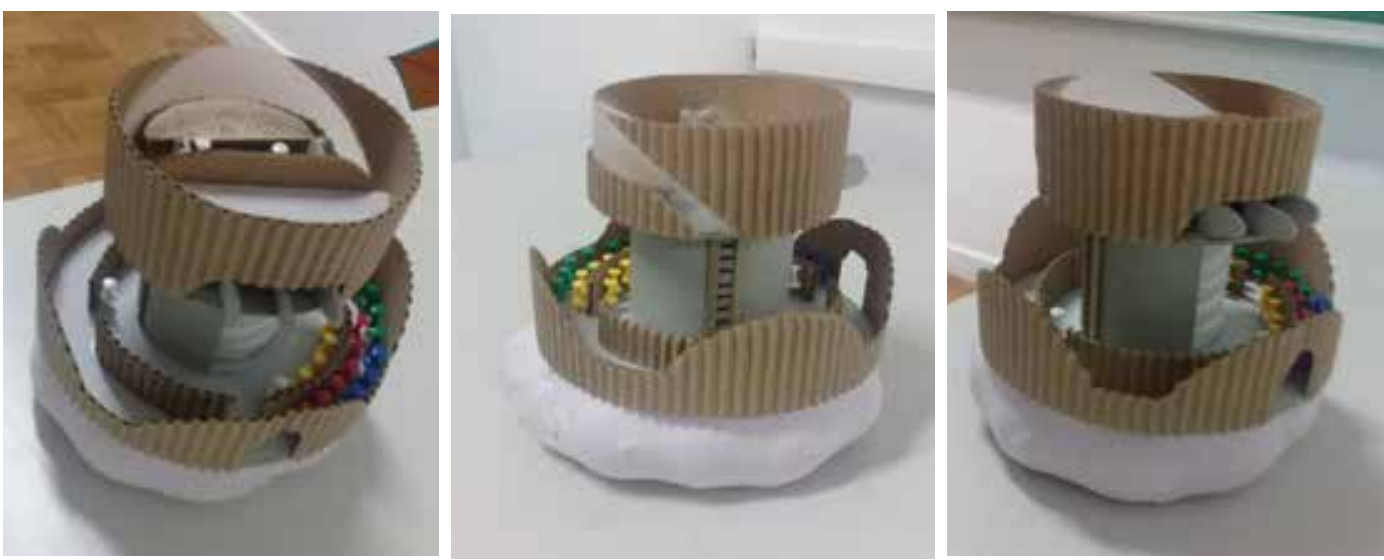

fig. 3.30 - modelo da cápsula de evacuação, parte do sistema de reação a emergências criado.

Fonte: acervo do autor.

4 Os professores das duas turmas que não quiseram participar da apresentação conjunta foram resistentes ao exercício projetual desde sua primeira aplicação, no semestre anterior. Esses professores são muito apegados ao ensino tradicional. Essa não adesão é comentada no item Resultados e na conclusão deste capítulo. 

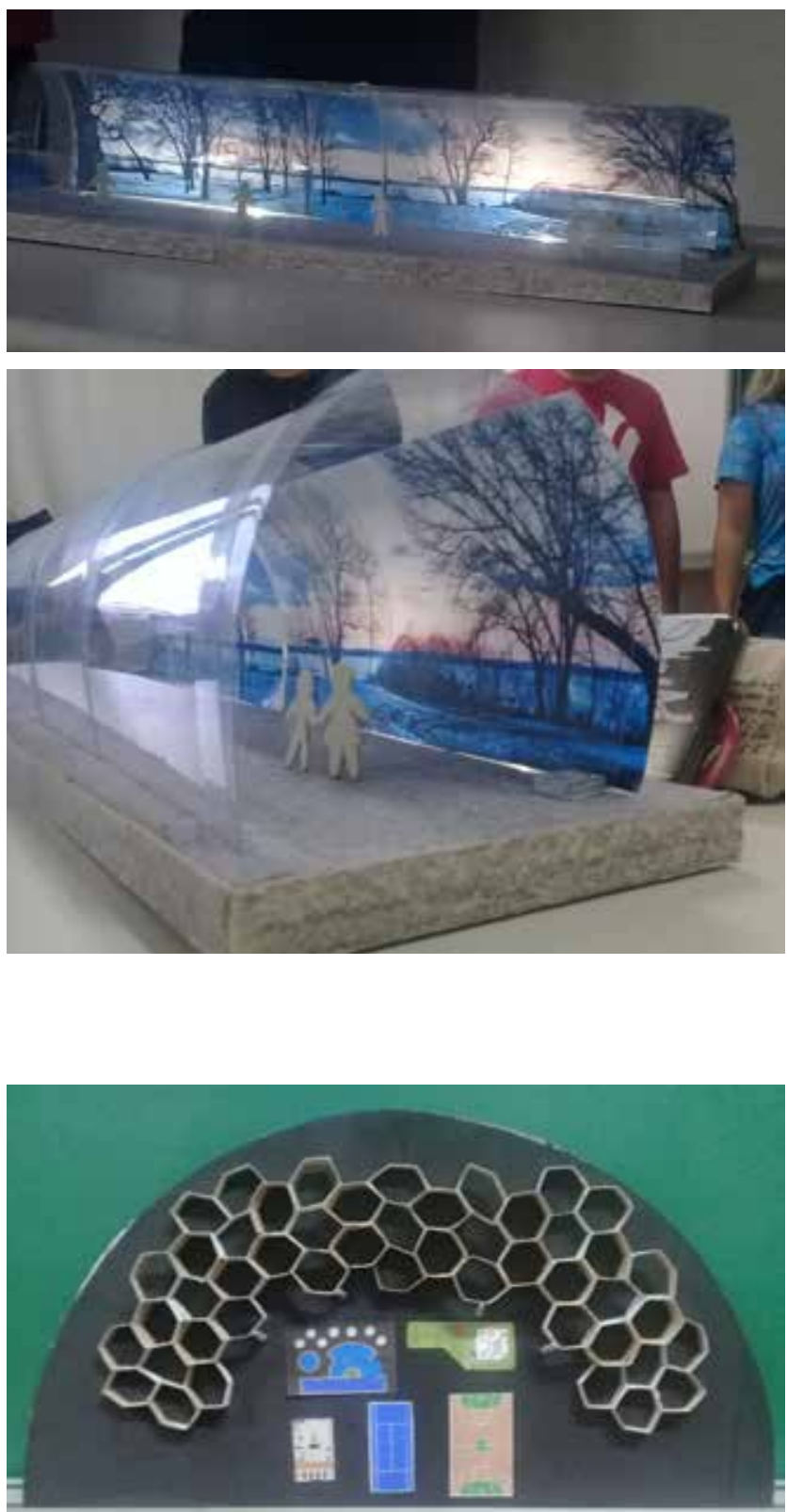

fig. 3.32 - proposta para expansão do domo residencial, reorganizando as residências a partir da estrutura de uma colmeia. Fonte: acervo do autor.

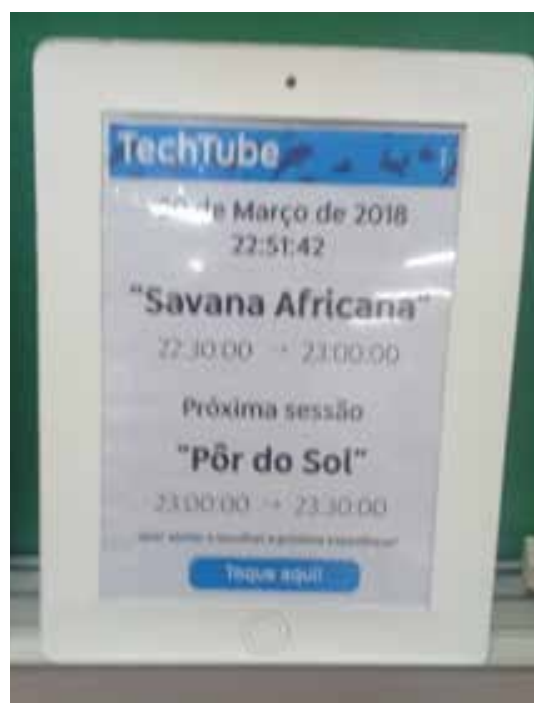

fig. 3.31 - TechTube - equipamento de aprendizagem e de lazer, é uma instalação de sistema de projeção multissensorial em tubos de trânsito de pedestres na Cidade Submarina. Fonte: acervo do autor.

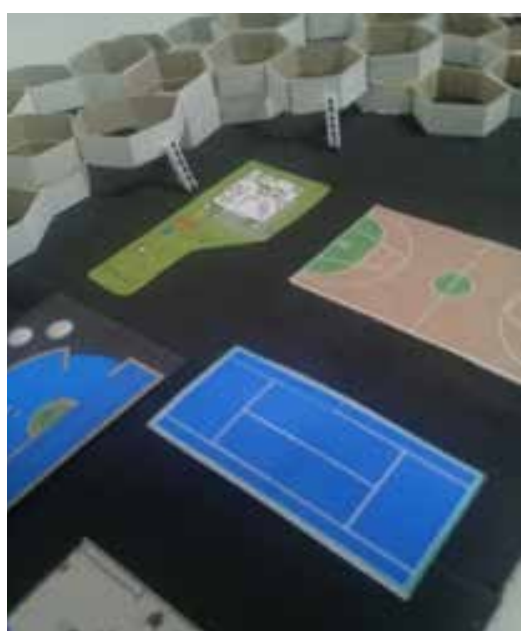

Encerramos o exercício apontando como algumas das ideias propostas poderiam ser utilizadas de forma muito similar no mundo real, ressaltando o paralelismo do que haviam criado com pesquisas de ponta que estavam em desenvolvimento.

Distribuí o instrumento de autoavaliação que estava desenvolvendo para essa pesquisa e pedi que os alunos das quatro turmas presentes respondessem. Deixei o formulários com os dois professores que não tinham participado da apresentação coletiva. 


\section{Os resultados (fundo do mar)}

Ao longo do exercício proposto, por ocasião das aulas de conteúdo de metodologia de projeto, foram distribuídos materiais impressos com o resumo do que havia sido ensinado. Percebi que isso contribuiu para a aprendizagem, complementando a explicação oral dada e apoiando o desenvolvimento posterior. Em uma das turmas, porém, os professores não seguiram exatamente o plano de aulas do exercício e esse encaixe entre teoria e prática não foi tão eficaz.

As Metodologias Ativas utilizadas na composição do exercício foram as seguintes: Aprendizado Baseado em Projetos e Aprendizado por Pares.

$\mathrm{O}$ aprendizado baseado em projetos esteve presente na estrutura projetual do exercício, seguindo quatro etapas da metodologia de Design Thinking: entender, interpretar, criar e prototipar. A quinta etapa, testar, não foi experimentada aqui devido à curta duração da atividade, mas poderia ter sido mesmo em um contexto especulativo, se imaginada uma jornada de usuário, ou seja, se nos imaginássemos dentro da Cidade Submarina utilizando o que havia sido criado.

$\mathrm{O}$ aprendizado por pares esteve presente em vários momentos, atuando como potencializador da aprendizagem. Na primeira aula fizemos um debate esclarecedor sobre técnicas de entrevistas após a dinâmica experimental e na segunda aula a interpretação conjunta dos resultados das entrevistas trouxe à tona discussões sobre fontes de pesquisa e gerou muitas situações-problema, que puderam ser compartilhadas com todos; a terceira e a quarta aulas propiciaram a realização de sessões de geração de ideias muito ricas e na quinta aula a apresentação participativa permitiu que cada grupo recebesse valiosas sugestões dos colegas. Tamanha integração potencializou os resultados atingidos pela turma, fazendo com que todos os projetos tivessem uma ótima apresentação e excelente concepção.

Notamos que nas turmas que fizeram a apresentação dos resultados do exercício em conjunto, esse processo ocorreu como previsto e os trabalhos tiveram o mesmo nível de desenvolvimento e acabamento. Nelas, foi interessante registrar que os resultados não apresentavam apenas simples artefatos, mas sistemas de objetos e, em alguns casos, como já foi mencionado, ocorreram interligações entre projetos desenvolvidos por outros grupos da turma. Esse foi um resultado inesperado da pesquisa e creio que isso ocorreu devido às apresentações participativas e ao brainstorming coletivo, que gerou um imenso número de ideias que puderam ser recombinadas.

A terceira turma ${ }^{5}$, aquela que não seguiu exatamente o planejamento do exercício, apresentou seus trabalhos em separado. Assim, não foi possível comparar in loco seu desenvolvimento aos das duas turmas que apresentaram em conjunto.

5 Chamo aqui de turmas A, B, C para facilitar a análise, mas cada turma é a reunião de duas pautas distintas que compartilham a mesma sala. 
Quanto aos resultados, em grande parte também foram criados sistemas, porém em quase todos os trabalhos houve uma preocupação com temas muito concretos e reais, como os relacionados à produção de alimentos, de oxigênio e água, e com preocupação em obter dados reais, como por exemplo a resistência de materiais, e nesses casos percebeu-se uma grande aproximação com o que já existe em nosso mundo real, com projetos que foram quase a recriação do que temos aqui para instalação na Cidade Submarina - inclusive com uma preocupação maior que a desejada em um exercício projetual focado na criatividade com questões técnicas de processos mecânicos e físicos. Nessa turma o deslocamento da realidade parece ter entrado em conflito com o real, e parte dos bloqueios parece não ter sido quebrada.

Por ocasião da conclusão do exercício, foi aplicado o questionário de autoavaliação desenvolvido a partir da Taxonomia de Fink (2007) a todas as turmas, visando identificar como havia sido a percepção dos alunos sobre o que tinham realizado. No questionário, as notas podiam assumir cinco valores, que variaram entre 0 (discordo totalmente) e 4 (concordo totalmente), evitando assim que o 3 fosse percebido como um talvez).

Houve 39 respostas, sendo 13 de cada turma, e obtivemos as seguintes médias:

\begin{tabular}{|l|l|l|l|l|l|}
\hline & $\begin{array}{l}\text { aprender } \\
\text { a aprender }\end{array}$ & $\begin{array}{l}\text { autorreali- } \\
\text { zação }\end{array}$ & $\begin{array}{l}\text { conceitos } \\
\text { chave }\end{array}$ & $\begin{array}{l}\text { aplicabili- } \\
\text { dade }\end{array}$ & importar-se \\
\hline Turma A & 3 & 3,7 & 3,61 & 3,54 & 2,54 \\
\hline Turma B & 2,92 & 3,3 & 3,23 & 3,54 & 3,07 \\
\hline Turma C & 3,15 & 2,92 & 2,69 & 2,84 & 2,3 \\
\hline Média geral & 3,02 & 3,3 & 3,18 & 3,3 & 2,64 \\
\hline
\end{tabular}

Fig. 3.33 - Respostas ao questionário. Fonte: acervo do autor.

Além disso, fiz duas outras perguntas aos estudantes: "Como você vê sua motivação ao longo do exercício?" e "O quanto você estranhou o exercício projetual Cidade Submarina?", utilizando a mesma escala, com os seguintes resultados:

\begin{tabular}{|l|l|l|}
\hline & $\begin{array}{l}\text { Como você vê sua motivação } \\
\text { ao longo do exercício? }\end{array}$ & $\begin{array}{l}\text { O quanto você estranhou o exercí- } \\
\text { cio projetual Cidade Submarina? }\end{array}$ \\
\hline Turma A & 3,46 & 2,15 \\
\hline Turma B & 2,84 & 3 \\
\hline Turma C & 2,69 & 2,46 \\
\hline Média geral & 3 & 2,54 \\
\hline
\end{tabular}

Fig. 3.34 - Respostas ao questionário (continuação). Fonte: acervo do autor.

Se considerarmos apenas a comparação com as médias na análise dos resultados da pesquisa, vemos que a turma $\mathrm{C}$ ficou abaixo da média em todas as perguntas, exceto em uma, onde obteve a maior média, em aprender a aprender, assinalando ser a turma que mais se sentiu desafiada. 
Essa turma foi aquela que não seguiu exatamente o planejamento do exercício, o que poderia nos dizer que o resultado reflete esse descompasso, que pode ter ocorrido por uma adesão menor dos professores da turma à proposta. Se considerarmos os resultados atingidos pelos grupos, projetos mais presos à realidade e à materialidade, vemos reforçada esta hipótese.

Ao interpretarmos graficamente os resultados segundo as categorias da Taxonomia da Aprendizagem Significativa de Fink (2007), obtemos:
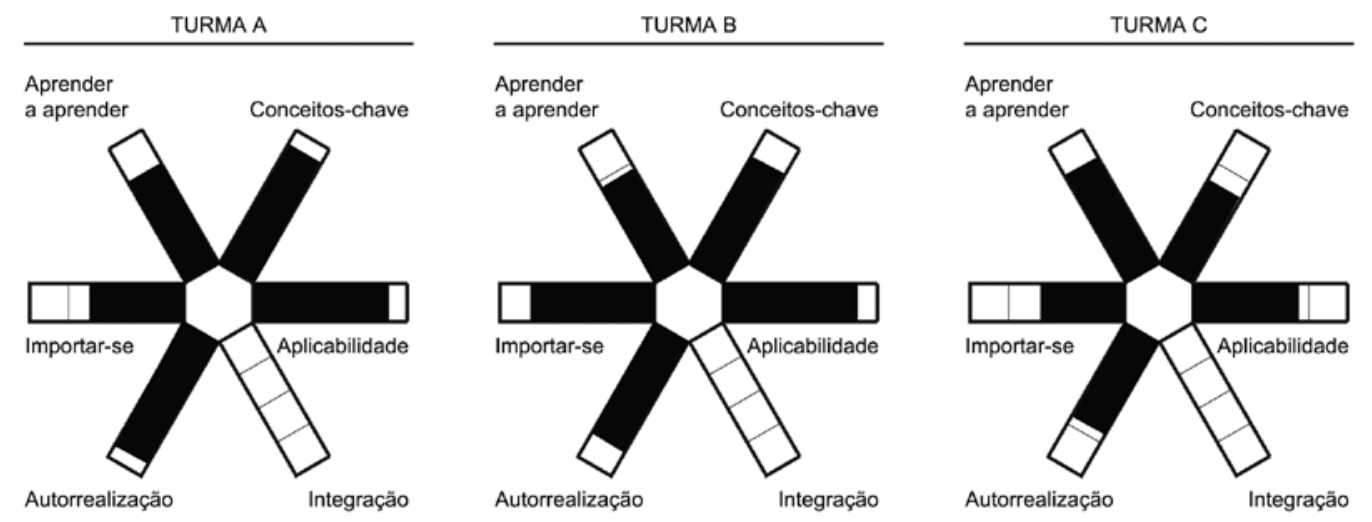

Fig. 3.35 - Representação gráfica dos resultados do questionário. Fonte: acervo do autor.

A partir dessa representação gráfica, percebemos que a aprendizagem significativa ocorreu nas três turmas, ainda que em menor medida na terceira, e que isto se deu em diferentes categorias, atuando não só na fixação dos conceitos metodológicos ensinados e experimentados, como na percepção de aplicabilidade do que foi aprendido e sobretudo gerando percepção de crescimento pessoal, de autorrealização.

Desse modo, ainda que subvertendo o plano de aulas e assim interferindo no potencial do exercício, percebemos que ele foi eficaz também na terceira turma, apesar de ter sido a turma com menor nota de motivação e que mais estranhou o exercício.

Avaliar o quanto a adesão dos professores às propostas inovadoras influi em seu resultado pode permitir criar propostas inovadoras que deem margem a essa resistência, sendo efetivas apesar dela.

Por outro lado, minha turma foi a que obteve as maiores médias, e que se declarou mais motivada e que menos estranhou o exercício. Considero esse desvio positivo como influência da observação participante, dado que eu tinha organizado e planejado o exercício e talvez tenha conseguido conduzir a turma com mais segurança.

\section{Avaliação da experiência (imersão)}

O exercício projetual Cidade Submarina foi um experimento muito organizado e sintético, que permitiu aos estudantes adquirirem conhecimentos teóricos sobre o projetar e em paralelo aplicar na prática o que tinham acabado de aprender. 
As aulas funcionaram como um metaprojeto, no interior do qual desenvolveu-se um exercício projetual, e os estudantes puderam perceber que academicamente o mais importante era o aprender a projetar que a realização do projeto em si.

Essa percepção, aliada à redução de limites gerada pelo contexto ficcional, fez com que eles se sentissem mais livres e motivados para terem ideias, e que as aulas fossem interativas, participativas e interessantes.

$\mathrm{O}$ absurdo e o incongruente estiveram presentes ao longo do processo e as situações que geraram foram bem humoradas. Isto favoreceu o pensamento divergente, houve uma quantidade maior de ideias e foram ideias não usuais, inusitadas. $\mathrm{O}$ brainstorm cruzado foi importaníssimo nesse processo pois fez com que múltiplas ideias surgissem e que os estudantes pudessem gerar ideias uns para os outros, e que recebessem ideias de toda a turma. As ideias surgiram sem censura e com mais prazer e depois revelaram-se interessantes e, por fim, o absurdo pareceu possível.

No final do exercício, foi incrível perceber a iluminação nos rostos de alguns alunos, que descobriram o quão viáveis eram suas ideias, e o poder modificador do Design, quando conheceram projetos reais muito similares aos que estavam propondo.

\section{5}

\section{Entrevistas com alunos}

Foram entrevistados quatro alunos, que aparecerão anonimamente como Alunos X, Y, W e Z.

As entrevistas foram não estruturadas, focalizadas. O objetivo era identificar se os estudantes tinham se sentido desafiados pelo exercício, se tinham conseguido se transportar para o ambiente ficcional e o quanto esse mergulho tinha afetado sua capacidade criativa.

As entrevistas foram feitas no final do semestre letivo, no último dia de aula de 2018.1, sendo o distanciamento proposital para evitar que a empolgação dos resultados obtidos influenciasse nas respostas.

Comecei a entrevista perguntando o quanto avaliavam que a cidade Submarina teria contribuído para sua visão de projeto, o quanto teria sido importante para o projeto que desenvolveram no resto do semestre, em relação ao que tinham trazido como bagagem do Projeto I e a como se viam quando entraram no curso de Design. A partir daí as entrevistas seguiram como conversas.

A aluna $\mathrm{X}$ disse que o mais interessante tinha sido poder explorar a criatividade, pois o exercício permitia que todos tivessem ideias absurdas, já que a cidade Subma- 
rina era uma "viagem", onde estavam projetando coisas impossíveis de fazer mesmo. "Provocou uma "viagem" no nosso pensamento também", nas palavras da aluna.

Em seguida, voltou a afirmar que a proposta totalmente criativa era o mais importante. Disse que sentia que quando os professores eram engajados nisso, o processo era muito facilitado. Por outro lado, se o professor não permite que você seja sempre criativo, isso bloqueia sua criatividade nos momentos em que você pode ser. No Projeto I a situação de projeto é muito concreta, definida e pequena e isso bloqueia a criatividade, e que se sentiu bloqueada no Projeto I também quando pensou que não conseguiria concretizar suas ideias. Na Cidade Submarina teve mais fluidez na criação porque sentia que as ideias poderiam ser concretizadas da maneira mais louca que fosse.

$\mathrm{O}$ aluno $\mathrm{Y}$ disse que quando há um caminho a ser seguido, sente que isso bloqueia a criatividade. Isso às vezes impede que o designer siga um caminho criativo que lhe é mais natural. Esse caminho a que ele se referiu entendi como um briefing muito preso ao real, com muitos parâmetros e limitações.

A aluna W relatou que no Projeto I precisava projetar para uma pessoa específica, que a visitavam para observar sua atividade profissional e, como acontece com qualquer atividade que sabemos que existe, formamos imagens pré-concebidas da atividade. Seu projeto I tinha sido realizado em uma escolinha de natação e antes de começar o projeto tinha pré-conceitos sobre professores de escolas de natação: devem gostar de crianças etc.- e quando está fazendo o projeto para alguém quer agradar àquela pessoa com base nos pré-conceitos que tinha. Gostou da Cidade Submarina por ser uma situação totalmente fictícia e isso lhe permitiu trabalhar no projeto de forma imparcial, sentiu que estava fazendo o projeto para a situação que tinha adotado sem pré-conceitos e sem uma bagagem prévia, e isso gerou algo bem mais genuíno.

$\mathrm{O}$ aluno $\mathrm{Z}$ disse que quando entrou no curso de Design fazia algumas coisas de que gostava, não sabe se os outros gostavam do que fazia mas ele gostava e queria aprender muito. Tinha entrado no curso pensando em evoluir naquilo que gostava e sabia fazer, mas agora percebia o quão importante era estar aberto a novas coisas. No projeto, achava importante aprender o processo e não só se orientar pelo resultado.

Com relação à Cidade Submarina, afirmou que não conseguiria ter entrado no contexto da Cidade Submarina se não tivéssemos realizado a aula de entrevistas com os professores fantasiados. Estava com um pé atrás mas na aula em que entrevistaram os professores fantasiados abriu sua cabeça e começou a pensar nas coisas mais diversas.

Em dado momento, nas entrevistas, comentei que apesar dos resultados serem muito inusitados, ainda achava que os alunos se permitiam pouco perante as possibilidades. Citei como exemplo, que nas entrevistas tinham per- 
guntado ao ancião se ele abrigaria refugiados em sua casa e o ancião tinha respondido que sim, os abrigaria dentro do armário. Num primeiro momento o ancião foi duramente considerado um ditador, porém disse que o armário era muito grande, lá dentro havia seis quarteirões de terrenos férteis com muito espaço para os imigrantes se instalarem. Depois disse que nesse período os projetos não tinham sido somente de artefatos, mas de sistemas e que na nossa sala a colaboração entre os projetos tinha produzido sistemas interligados de soluções. Perguntei aos alunos $W$ e $Z$ qual era sua precepção quanto a isso.

A aluna $\mathrm{W}$ adorou a aula de apresentação participativa (a aula em roda). Essa apresentação em que as outras pessoas da sala também podem falar foi a única aula de apresentação de projeto em que prestou atenção até aquele dia, realmente não conseguia prestar atenção à apresentação dos outros. Ela é muito dispersa e tem dificuldade em aprender por causa disso, sempre teve dificuldade em manter-se concentrada. As aulas de Projeto II foram aquelas em que tinha prestado mais atenção até então, e tinha participado de todas as apresentações porque podia colaborar também, estava com vontade de aprender e colaborar com o processo.

Para o aluno $\mathrm{Z}$ as apresentações participativas permitiram integrar seu projeto aos demais. Seu problema era relacionado a situações de emergência e ao longo das apresentações as ideias de integração iam surgindo: posso usar essa parte do projeto dele para alertar as pessoas, se passar no "Techtube" (dispositivo criado pelos alunos para a Cidade Subamrina) um alerta de evacuação posso conseguir tal coisa, e assim por diante. Os sistemas de soluções integradas foram se construindo e complementando nessas apresentações.

\section{Pedi sugestões para futuras aplicações da Cidade Submarina.}

A aluna $X$ sugeriu que na próxima edição acontecesse alguma coisa com a mulher misteriosa, que se revelasse de onde veio e o que estava procurando.

O aluno Y pensa que o tempo da Cidade Submarina poderia transcorrer de forma diferente: enquanto o visitante vivenciasse calmamente a passagem de alguns dias, lá fora já teriam se passado anos.

A aluna W sugeriu que houvesse uma internet só da Cidade Submarina, desconectada da internet daqui de fora. Isso poderia ser um elemento político-doutrinário, uma internet controlada que filtrasse as notícias vindas do mundo exterior.

Emergiram nitidamente das entrevistas a opinião de que a dramatização na aula em que entrevistaram os moradores contribuiu muito para que se permitissem mergulhar no contexto ficcional e que o professor é um agente que pode aditivar ou minar os processos criativos pelo seu engajamento ou oposição, e que processos colaborativos em disciplinas de projeto permitem expandir o campo das ideias e ao mesmo tempo possibilitam olhares muito diferentes sobre cada projeto. 


\section{6}

\section{Entrevistas com professores}

Foram entrevistados três professores que aparecerão anonimamente como Professor 1,2 e 3.

As entrevistas foram não estruturadas, focalizadas. $\mathrm{O}$ objetivo foi perceber a opinião dos professores sobre o exercício projetual, se avaliam que a utilização do contexto ficcional contribuiu para resultados mais criativos que os habitualmente alcançados e saber como avaliam o papel do professor no exercício projetual.

O professor 1 é professor colaborador, e não de pauta. Escolhi entrevistá-lo porque circulou por todas as turmas, e teve uma visão geral de tudo o que estava acontecendo. O professor 1 foi um dos gerentes da Cidade Submarina e participou das duas aplicações do exercício.

As professoras 2 e 3 são professoras de pauta, isto é, responsáveis por uma turma específica e participaram de todas as etapas do exercício acompanhando o mesmo grupo de alunos. Uma das duas compartilhou a turma comigo, outra era de uma segunda turma, a que se uniu à nossa para a apresentação final.

\section{Entrevistei-os sobre a aplicação 2018.1 e comecei perguntando, em linhas gerais, sua opinião sobre a Cidade Submarina.}

O professor 1 disse ter achado o exercício muito interessante em primeiro lugar porque criou um ambiente de elos afetivos em um processo divertido, mas talvez isso não tenha sido percebido assim para todos os professores, pois não sabe se todos estão abertos a coisas novas. Mencionou que nos projetos reais ficamos sempre tentando identificar as personas envolvidas e na Cidade Submarina os professores se transformaram nessas personas.

Os papéis desempanhados e os figurinos utilizados trazem algo de teatro, e em sua opinião não poderia ter sido de outra forma já que o exercício propunha um mundo paralelo até certo ponto surrealista. Considerou a caracterização dos professores fundamental.

A professora 2 ressaltou inicialmente que duas aplicações tinham sido muito pouco, que o exercício deveria ter continuado pelo menos por mais dois semestres, pois ainda havia muitas possibilidades de aprimoramento. Expliquei que o exercício havia sido descontinuado por determinação da coordenadora do projeto, que por motivos não revelados resolveu mudar todo o planejamento da disciplina e não possibilitou a continuação, o que foi mesmo uma pena.

A seguir, disse que o exercício rompe com muitas coisas que os alunos têm como verdades absolutas a partir da experiência que tiveram no projeto anterior. Não que sejam coisas erradas, mas não são o único modo de ver. Por estarem 
habituados ao modelo escolar de que o que o professor diz é o certo e pronto, vira um modelo. $\mathrm{O}$ fantástico rompe com isso, e o exercício também poderia ter continuado como pesquisa para maior validação - poderíamos ter retomado o design-parceria, que é algo que vem se perdendo nos projetos da PUC. Por mais que estivéssemos projetando para um lugar que não existe, o exercício poderia ter sido ampliado para experimentações e validações no mundo real, após a apresentação final eles poderiam conversar com pessoas especialistas nas áreas para as quais criaram ideias.

Para a professora 2, a abertura real do exercício, quando os alunos têm contato com os professores fantasiados e os entrevistam, é o momento mágico em que "tiramos os alunos da caixinha. Relatou momentos semelhantes em outras aulas e pesquisas em que participou, ressaltando o quanto esse momento quebra-gelo é importante.

Para a professora 3 o mais incrível do exercício foi ele permitir que os estudantes que exercessem plenamente a imaginação, que nos dias de hoje há pouco espaço para isso na universidade. Temos cada vez mais dados sobre a realidade, e isso é muito bom, mas há pouco espaço para o que é lúdico, para o imaginário e para as situações hipotéticas. Em sua opinião, a universidade é um espaço que deveria se abrir mais a isso, a imaginar situações diferentes das nossas que nos tirem de nossa zona de conforto. Para ela a experiência foi encantadora e sentiu-se triste por não termos continuado as aplicações do exercício.

A professora acredita que a caracterização dos professores como personagens e a teatralização das entrevistas contribuíram para uma aproximação entre alunos e professores, à medida que permitiu uma visão mais humanizada, menos estereotipada do professor.

Perguntei a seguir se o universo ficcional teria contribuído para o desenvolvimento da criatividade dos alunos.

O professor 1 crê que sim, entende a utilização do universo ficcional como uma boa ferramenta e ressalta que houve em semestres anteriores outras dinâmicas que também funcionaram no Projeto II. Lembrou que na primeira aplicação os textos iniciais deram margem a discussões éticas e ecológicas entre os professores e percebeu a segunda aplicação como uma evolução daquela. A seu ver a dinâmica potencializou a criatividade dos estudantes. Ressaltou que, por ser um contexto surreal e narrativo, não foi completamente compreendido por alguns, mas não vê isso como um ponto contra porque na maioria das vezes há alunos que não compreendem os enunciados mais objetivos e óbvios.

A professora 2 percebeu resistência nos alunos com relação ao tema, por acharem muito infantil ou muito difícil no início criar algo para um universo ficcio- 
nal, mas isso foi percebido no primeiro encontro, no briefing. À medida que foram sendo dadas condições de desenvolvimento do projeto eles foram relaxando e até brincando com aquilo.

Com relação ao uso do universo ficcional como elemento ativador da criatividade, a professora 2 disse que com certeza isso ocorreu, que se faz pouco isso na faculdade e se faz pouco isso na vida de um modo geral. Isso tem virado algo quase exclusivo da educação infantil e isso tem deixado as pessoas mais duras, "dentro de quadradinhos". É difícil querer quebrar paradigmas se estivermos pensando sempre nas mesmas coisas e ensinar está totalmente conectado a esse processo - ensinar Design mais ainda.

A professora 3 acredita que o universo ficcional contribuiu para que atingissem resultados mais criativos e inusitados no exercício projetual, mas ressaltou a dificuldade que percebeu em alguns alunos em romperem alguns limites auto-impostos, pressupostos construídos a partir da realidade. Percebeu que eles estavam tão condicionados à realidade que tiveram uma certa dificuldade para entrar no universo de ficção, porém quando perceberam que podiam mergulhar nele tiveram um processo criativo muito rico. Isso é muito importante em um mundo polarizado e tão cheio de dualidades, onde a criatividade faz perceber a possibilidade das nuances.

Pedi sua opinião sobre o planejamento das aulas. Sabendo que há uma expectativa de aulas mais práticas em Projeto e que os alunos não costumam participar nem prestar atenção em aulas teóricas dentro da disciplina de Projeto, o exercício intercalou aulas de teoria seguidas de atividades de prática onde o que foi aprendido podia ser aplicado imediatamente.

O professor 1 citou a dinâmica de entrevistas como um ponto forte. Em outros semestres, em ocasiões onde os estudantes precisaram entrevistar pessoas (praia, produtor rural, etc) o processo foi muito mais difícil e menos bem sucedido. Pelo fato de os professores assumirem personas, os estudantes puderam perceber imediatamente se tinham obtido boas respostas e podiam reformular ali mesmo suas perguntas. Para o professor 1 a aula sobre métodos de entrevistas seguida das entrevistas aos moradores caracterizados serviu para que os estudantes aprendessem a entrevistar pessoas com muito mais facilidade.

O professor ressaltou que não tínhamos um roteiro que previsse todas as respostas, mas poucas informações sobre o perfil do seu personagem. Isso fez com que durante a entrevista os alunos encontrassem respostas contraditórias e isso muitas vezes era externalizado durante a entrevista, como um exemplo citado pelo professor, em que uma aluna perguntou se na Cidade Submarina havia redes wi-fi e ele disse que sim. A aluna em seguida disse que o entrevistado anterior tinha afirmado 
que havia rede. Isso era muito interessante, pois pessoas diferentes podem dar respostas diferentes a perguntas idênticas e é importante para que o estudante aprenda a comparar essas divergências e a escolher uma posição sua.

A professora 2 a esse respeito diz que não tem como lecionar projeto sem dar aulas, mas essas não podem ser aulas de conteúdos absolutos, é importante explicar conceitualmente o que é cada coisa sem querer se prender a definições definitivas porque no mundo do Design as coisas também são assim, se reconfiguram de forma complexa como os problemas de Design. Falta a alguns professores de projeto esse entendimento do que é ensinar projeto. A forma que isso foi feito no exercício da Cidade Submarina foi muito positiva, enquanto você está fazendo você está explicando por que está fazendo, e no Design é importante que o aluno tenha a possibilidade de fazer algo errado, pois aprende muito mais com isso que se ficar preocupado em seguir algo muito linear que conduza sempre ao certo.

A professora 3 vê a construção de um processo metodológico de como projetar como algo difícil de os estudantes entenderem em um primeiro momento, mas acredita que a Cidade Submarina contribuiu para essa compreensão e para que eles depois pudessem estruturar melhor sua experiência de projeto na faculdade.

Citou o humor como um grande aliado no processo de aprendizado, não um humor pastelão nem agressivo, mas o humor que quebra um pouco o lado sisudo do aprendizado. O termo metodologia é um tanto assustador para os estudantes, invoca a imagem de uma figura séria, toda de preto. A oportunidade de revestir a metodologia com uma atmosfera mais lúdica é fantástico, é uma ferramenta poderosa de aprendizado, pois estamos vendo o quanto as vias clássicas ou tradicionais não estão funcionando. Precisamos buscar outras formas para nos conectarmos com os alunos.

A partir do que tinha sido dito, sobre os papéis assumidos pelos professores terem rompido com uma visão tradicional do que é ser um professor, e de os professores passarem a ser percebidos como tutores daquele mergulho na Cidade Submarina, perguntei como avaliavam esse novo papel do professor no processo de aprendizagem.

O professor 1 comentou no início da entrevista apenas que nem todos os professores estão abertos a coisas novas. Não fiz essa pergunta a ele, pois como professor colaborador participou do início e depois somente colaborou em pontos específicos do exercício e assistiu à apresentação final, sem ter acompanhado especificamente uma turma.

A professora 2 lembrou das reuniões intermediárias de planejamento em que muitas vezes a postura do aluno era criticada (eles não vêm, eles não fazem) mas para ela era claro que o problema não estava nos alunos, mas nos professores. Alguns professores têm um movimento muito conservador do poder que têm sobre os alunos, o 
poder de dar notas, do escolar, de dar errado e dar certo e do poder te ter sua disciplina e não querer delegar responsabilidade aos professores colaboradores. Percebeu na cidade Submarina uma resistência nesse sentido nos professores de uma turma que era muito maior que qualquer resistência dos alunos, pois era uma resistência velada e não declarada. Na turma desses professores o exercício não funcionou tão bem porque querer encaixar algo que tem tudo para ser fantástico, uma experiência orgânica e divertida e tentar encaixar num "modelinho" que já existe não funciona. Sente que nesse caso foi uma falsa adesão dos professores ao experimento, e desse não envolvimento veio o não envolvimento dos alunos, e consequentemente foi a turma com piores resultados.

Em aulas de Design, onde se espera que as pessoas sejam muito criativas, vemos alunos com a expectativa de adivinhar o que o professor quer receber. É difícil quebrar isso e fazer o aluno ver que ele não tem como objetivo agradar ao professor mas aprender e crescer na disciplina. Quando o professor, ao invés de atentar a isso, já dá inputs do que quer, o aluno de cara já não conseguirá fazer um brainstorm livre desses pré-conceitos.

A professora 3 lembrou que quando era estudante lutava em um ambiente de ensino tradicional para quebrar certos padrões e para fazer coisas ousadas, hoje como professora ela instiga os alunos a fazerem isso. Citou um projeto, da época que era estudante, em que um grupo pediu ao professor para projetar um disco voador. Isso gerou bastante polêmica na época, os professores não queriam permitir porque não haveria dados da realidade e não seria possível prototipar e testar. $\mathrm{O}$ grupo argumentava que se não pudesse fazer esse tipo de projeto na faculdade, onde mais poderia fazer? Se os designers não puderem sonhar, ficarão só recriando as mesmas coisas do mundo e não caberá antecipar futuros, nem pensar em inovação. A imaginação é a base para a inovação, a história da humanidade mostra isso. Quanto menos trabalharmos esse lado, mais duros e frios vamos nos tornar.

As entrevistas com os professores corroboraram as percepções dos alunos quanto à dramatização como elemento essencial para a quebra com a realidade $\mathrm{e}$ para promover maior envolvimento de alunos e professores no processo.

Também vieram à tona críticas a professores que não se identificaram com o exercício mas não se posicionaram abertamente em relação a isso, participando de forma não autêntica e sem engajamento; o que em sua turma (C) gerou certo ar de resistência e prejudicou em certa medida os ganhos obtidos com o exercício projetual. Quando observamos, porém, os resultados da autoavaliação feita com o instrumento criado a partir de Fink, no item resultados do diário de bordo deste capítulo vemos que mesmo nessa turma $(\mathrm{C})$ os objetivos foram atingidos e o aprendizado significativo ocorreu. 
Os professores não falaram sobre o processo colaborativo de aprendizagem, que pelos alunos foi apontado como o principal ganho e motivador de participação. Tal ponto, em função da interrupção nas experimentações do modelo, levaram-me a experimentar melhor os processos colaborativos no Estúdio de Desenho ESPM, nos dois semestres seguintes (capítulo 4).

Os professores falaram sobre a importância da fantasia e de projetar para situações abertas para o desenvolvimento do pensamento projetual criativo, como forma de aprender a projetar com menos bloqueios, e da importância de criticar as ideias e trazê-las para a realidade no momento certo.

Foi interessante perceber que os pontos principais para alunos e professores têm diferentes pontos de foco: enquanto nos alunos esteve na aprendizagem significativa a partir do processo, para os professores deslocou-se para o contexto. Isso de certo modo é natural e desejado, pois o contexto vem do plano, do método, e os alunos terem desfrutado do desenvolvimento me fez perceber que se permitiram transportar pelo método proposto.

\section{7}

\section{Testes de aplicação no ensino fundamental e no ensino médio}

Três testes de aplicação da cidade Submarina foram feitos no segundo semestre de 2018. Dois deles por mim e o terceiro em contexto totalmente diferente, pela professora Ana Erthal, da ESPM.

Em julho de 2018 fiz dois workshops da Cidade Submarina em escolas de ensino fundamental e médio: a escola Eleva, tida como uma das escolas mais inovadoras da cidade do Rio de Janeiro, e o Colégio Naval, considerada uma excelente instituição de ensino, porém tida como pouco criativa por ser uma instituição militar.

No colégio Eleva os participantes tinham entre 12 e 13 anos, eram alunos do sétimo e oitavo anos do ensino fundamental. Participaram cerca de 30 alunos.

No Colégio Naval os participantes foram alunos do ensino médio, de 15 a 18 anos de idade, um professor de informática e um oficial ligado à prática de esportes. Participaram 26 pessoas.

Como o exercício projetual da Cidade Submarina foi estruturado a partir das etapas da metodologia Design Thinking, imaginei que poderia estruturar a atividade desenvolvendo-a em etapas a partir dessa metodologia, como um exercício rápido de uma tarde. O objetivo aqui era observar a imersão na ficção e o quanto o contexto podia despertar a criatividade em estudantes que não cursavam Design e não tinham ainda qualquer experiência no desenvolvimento de projetos. 
Iniciei os dois workshops explicando o que é essa metodologia, dando exemplos e falando sobre áreas de atuação do Design. Assim que terminei a explicação inicial disse que desenvolveríamos como aplicação prática o exercício da Cidade Submarina.

Distribuí o kit de textos, planta e carta náutica aos participantes e disse para lerem que em poucos minutos eu retornaria com um convidado. Fora de sala, vesti meu casaco de velejador, coloquei óculos escuros e a barba postiça e voltei para interpretar o ancião da Cidade. Contei a história do experimento que se converteu em civilização, apresentei aos estudantes os dois artigos de jornal, o que falava sobre a cidade e o outro que relatava o caos que tinha se instalado com os imigrantes.

Exemplificando o processo de Design Thinking, ressaltei que aquela era a etapa de entender o problema. Os estudantes leram os dois artigos e entrevistaram o ancião da cidade.

No colégio Eleva, essa fase foi muito confusa, alguns estudantes faziam perguntas absurdas e até debochadas no início, como se estivéssemos fazendo uma brincadeira, mas aos poucos começaram a surgir perguntas interessantes porém sem profundidade.

No Colégio Naval inicialmente houve silêncio. Aos poucos, começaram a perguntar timidamente questões triviais e após alguns minutos estavam fazendo também perguntas interessantes e se aprofundando nos questionamentos, precisei inventar muitas respostas de improviso e com atenção para manter a coerência. Perguntaram sobre questões sociais, políticas, sobre saúde, sobre questões técnicas, sobre a planta da cidade, e a entrevista se alongou por quase uma hora, o dobro do tempo previsto e o triplo do tempo utilizado no outro colégio.

Em seguida, pedi aos estudantes para listarem em grupo pelo menos 10 problemas que tinham identificado a partir da entrevista. Os alunos do Eleva listaram problemas interessantes e muito próximos da realidade deles, como falta de áreas para a prática de esportes, falta de um meio que permitisse aos moradores irem à superfície com mais facilidade, problemas de moradia. Listaram muitos problemas, alguns grupos conseguiram mais que os dez pedidos. Os alunos do Colégio Naval listaram menos problemas, nenhum grupo conseguiu atingir os dez problemas dentro do tempo a isso destinado, porém foram problemas não tão próximos a eles, mas em grande parte problemas de maior impacto social, como a falta de um sistema político estruturado, a produção de oxigênio, a falta de um protocolo de recepção a imigrantes.

$\mathrm{Na}$ fase de interpretar o problema, permiti que fizessem novas perguntas ao ancião, mas pedi que pensassem em situações análogas (isto é, similares) em que um problema parecido se apresentasse, para observarem como tinha sido o foco de projeto e para verem como eram as soluções e a relação com os usuários. 
No Eleva essa fase foi bastante breve pois os estudantes fizeram uma lista rápida do que lembravam e deram a etapa por encerrada. No Colégio Naval também foi uma fase rápida, porém os estudantes fizeram breves pesquisas pelo celular. Em ambos, pedi que os grupos escolhessem um problema com o qual gostariam de desenvolver o exercício.

A seguir foi a etapa de ideação, que é uma geração de ideias. Essa fase durou cerca de 40 minutos no Eleva e cerca de 1h:20 no Colégio Naval, o dobro do tempo.

Nos grupos do Eleva, percebi que somente dois ou três participantes estavam gerando ideias, os demais estavam usando o celular ou brincando, e esses não reagiram aos chamados que fiz para participarem e estavam atrapalhando os demais com o barulho que faziam.

No Colégio Naval todos participaram, discutiram e escreveram suas ideias. Trabalharam em silêncio, ou falando baixo.

As etapas de prototipagem e testagem não puderam ser feitas em função do tempo disponível, mas ao término da ideação pedi que cada grupo desenhasse sua solução numa folha grande de papel para apresentarem à turma.

No Eleva muitos dos estudantes que fizeram bagunça na etapa anterior participaram da elaboração dos cartazes de apresentação, e na hora de apresentar os grupos foram à frente da sala e todos falaram. As ideias geradas pelos alunos de lá foram muito interessantes e criativas, porém eram ideias de itens ou situações isoladas, como aconteceu na primeira aplicação do exercício projetual na PUC, em 17.2. Como exemplo, cito uma arena de esportes aquáticos em que novas modalidades esportivas seriam criadas considerando a flutuabilidade e a dinâmica de fluidos em sua elaboração.

No Colégio Naval, onde todos tinham participado ativamente na geração de ideias, em cada grupo somente um ou dois estudantes trabalharam na preparação dos cartazes. Os outros integrantes ficaram ao redor, opinando sobre os desenhos e sobre o conteúdo da prancha. As soluções a que chegaram foram mais sistêmicas, como aconteceu na segunda aplicação do exercício projetual na PUC. Pensaram, por exemplo, em um protocolo de recepção a imigrantes que teria questões relacionadas a saúde, a tradução / compreensão de diferentes idiomas, a programa de capacitação e emprego e a programa de moradia. Pensaram em uma proposta de programa de ensino e em um novo sistema político baseado no conhecimento.

Ao final do workshop, alguns alunos do Eleva me perguntaram sobre como é estudar e trabalhar com Design. Um dos estudantes disse que esse exercício era muito avançado para a turma deles. Os alunos do Colégio Naval pediram indicação de autores de Design Thinking. Alguns fizeram também perguntas sobre como é estudar e trabalhar com Design e um grupo disse que era responsável pelo jornal humorístico dos alunos, o Gingilim. 
Nos dois casos, os estudantes eram de ensino básico ou médio, e uma das escolas tem aulas mais abertas e inovadoras enquanto a outra tem o modelo tradicional de ensino como base. A diferença de idade e maturidade entre os estudantes das duas instituições não permite traçar hipóteses sobre as diferenças observadas no processo e nos resultados, apenas relatá-los, porém tais resultados nos deixam ver que esses estudantes alcançaram resultados conceitualmente (não formalmente, só enquanto ideias) muito próximos aos que foram obtidos pelos estudantes de Design nas duas edições da Cidade Submarina que aconteceram na PUC.

Claro que o tempo para elaboração e apresentação foi muito menor (três horas) que nos exercícios projetuais realizados na PUC (três semanas de duração), e os alunos de Design já no segundo período possuem habilidades e competências desenvolvidas no primeiro semestre e uma inclinação natural para o desenho (representação) e criação (ideação). Dados esses devidos descontos, essencialmente os resultados obtidos pelos estudantes tão diferentes da escola liberal, da escola militar e do curso de Design têm paridade.

A meu ver, o que conduziu a esse nivelamento foi o distanciamento cognitivo gerado pela heterotopia do exercício, que atuou como um desobstrutor de criatividade, pois os três universos tinham sido transportados para o mundo-ficção da cidade Submarina.

A professora Ana Erthal, da ESPM Rio, fez uma aplicação completamente diferente da Cidade Submarina em uma turma de sétimo ano do Colégio Éden. Nesse colégio, a professora leciona uma disciplina nova na grade, criação de games.

É uma disciplina não convencional, sem provas ou notas. No primeiro trimestre haviam trabalhado revisões críticas de jogos, no segundo trimestre trabalharam narrativas e no terceiro criaram conceitos de jogos.

$\mathrm{Na}$ etapa de narrativas, a professora apresentou aos alunos a Cidade Submarina fornecendo a eles os textos, planta baixa e carta náutica. A partir do material original os estudantes criaram narrativas complementares com novos personagens e situações. Partiram da cidade, dos animais, dos habitantes ou da estrangeira que ninguém conhecia direito e que não se comunicava plenamente. Em seguida, a turma teve quinze dias para propor conceitos e esboços de jogos.

Erthal conta que no dia da apresentação dos trabalhos havia outros professores e quarenta alunos presentes, de duas turmas. Os estudantes eram barulhentos, estavam alvoroçados e a coordenadora da escola assistiu às apresentações. Ao ver cada um apresentando, a coordenadora mostrou-se surpresa com a facilidade com que cada um tinha conseguido desenvolver sua narrativa a partir de uma narrativa dada, criando outras histórias e outros personagens, pois normalmente não conseguem fazer isso quando precisam escrever textos nas aulas de geografia, história, ou mesmo português, por exemplo, pois têm uma dificuldade enorme em imaginar cenários. A partir 
das curtas narrativas de jornal sobre a Cidade Submarina tinham conseguido desenvolver projetos gigantescos, com textos, desenhos, pintura e dinâmicas de jogos.

Os alunos ficaram muito felizes com os resultados e a partir de certo ponto passaram a pedir acompanhamentos em particular à professora - não queriam que os outros soubessem o que estavam fazendo pois tinha se estabelecido um clima competitivo nas turmas e todos queriam criar o melhor jogo.

Foram três aplicações do contexto ficcional da Cidade Submarina totalmente diversas de sua concepção original, duas delas apoiadas no Design Thinking e a terceira como cenário, ponto de partida para criação de mundos. Todas foram muito bem sucedidas e geraram resultados criativos e surpreendentes.

A aprendizagem colaborativa foi algo muito presente em todas as edições e testagens da Cidade Submarina. Um novo experimento foi imediatamente concebido a partir dela, ampliando a criação colaborativa em um exercício projetual online do qual participariam estudantes de diferentes países. Para planejar essa nova aplicação, estudei a metodologia ativa Challenge Based Learning, ou Aprendizado por Desafio, desenvolvida por um consórcio liderado pela Apple. O Aprendizado por Desafio é uma metodologia para aprendizado por projetos em ambientes digitais colaborativos.

Não foi possível, no entanto, testar essa variante da Cidade Submarina e o planejamento inicial tornou-se uma das proposições de práticas pedagógicas apresentadas no capítulo 5. Apesar disso, na ocasião eu já havia começado a investigar outros aspectos da aprendizagem colaborativa no Estúdio Livre de Desenho ESPM. 


\section{4 Estúdio Livre de Desenho: um estudo de autoaprendiza- gem inspirado nos Grupos Operativos de Pichón-Rivère}

$\mathrm{Eu}$ apresento a página branca.

A árvore sem sementes.

$O$ vidro sem nada na frente.

Arnaldo Antunes

Imagine uma escola em que as disciplinas têm objetivos claros, mas percursos abertos, em que cada estudante pode experimentar o caminho que quiser e todos aprendem pelas experiências coletivas, pela pesquisa e práticas compartilhadas.

Cada disciplina uma página em branco a ser preenchida, remexida, investigada, cortada, moída, transcrita, dobrada, desenhada. Cada semestre, curso, um livro montado pelo estudante com textos, imagens e pensamentos seus sobre aquilo que the foi dado pensar no início da espiral de aprendizagem significativa em que se viu enredado.

O grande valor dado pelos estudantes à estrutura de co-criação e às apresentações participativas da Cidade Submarina me fez começar a pensar em sugestões de práticas pedagógicas a partir de experiências de aprendizagem colaborativas, que serão parte da conclusão desta tese, e a impossibilidade de seguirmos com a Cidade Submarina, aliada a condições favoráveis na ESPM, possibilitou já experimentar algo nesse sentido.

\section{1}

\section{A formação do Estúdio Livre de Desenho}

A experiência colaborativa da Cidade Submarina se desenvolveu a partir de uma Metodologia Ativa chamada Aprendizado por Pares, que esteve presente em vários momentos do experimento: no debate pós entrevistas, na interpretação conjunta de resultados, na discussão sobre situações-problema, nas sessões de geração de ideias e nas apresentações participativas. Tamanha integração potencializou os resultados atingidos pela turma, fazendo com que todos os projetos tivessem uma ótima apresentação e excelente concepção.

Sobre o Aprendizado por Pares, a aplicação da metodologia na Cidade Submarina diferiu de como foi tradicionalmente concebida ${ }^{1}$ pelo professor Erik Mazur,

1 Beltrão (2017) p. 33/34 
do Departamento de Física de Harvard. Originalmente é uma metodologia apoiada na discussão de textos, criada para gerar maior interesse e participação dos alunos em aulas conceituais e densas.

O Aprendizado por Pares tem como objetivos melhorar a aprendizagem pela participação assertiva dos estudantes, estimulando o debate e a argumentação e aprimorando o processo colaborativo. Visa facilitar o entendimento e aplicabilidade dos conceitos das aulas, utilizando a discussão entre os alunos como fator motivador.

$\mathrm{Na}$ Cidade Submarina havíamos criado esse caráter colaborativo nas pesquisas conjuntas, entrevistas e geração de ideias, e nas apresentações colaborativas, em que toda a turma podia opinar sobre todos os trabalhos, mostrando diferentes e diversos olhares.

Em paralelo, em apoio às aulas de Desenho Livre ${ }^{2}$, tínhamos começado no primeiro semestre de 2018 na ESPM uma oficina de desenho nas quartas-feiras, como uma atividade extraclasse. A intenção originalmente era oferecer acompanhamento extra, pois o professor reclamara bastante de ter 40 alunos e não poder dar a atenção necessária a todos. Imaginávamos que a atividade teria baixa adesão dos alunos, assim comentei sobre a oficina em outras turmas em que lecionava, e tive a grata surpresa de encontrar um grupo de mais de quarenta estudantes no primeiro dia, a maior parte do primeiro período mas alguns do segundo e terceiro períodos.

Foi preciso dividi-los em dois grupos, em horários diferentes. Conversamos sobre o que iríamos fazer e sobre as expectativas e o que veio à tona foi o desejo

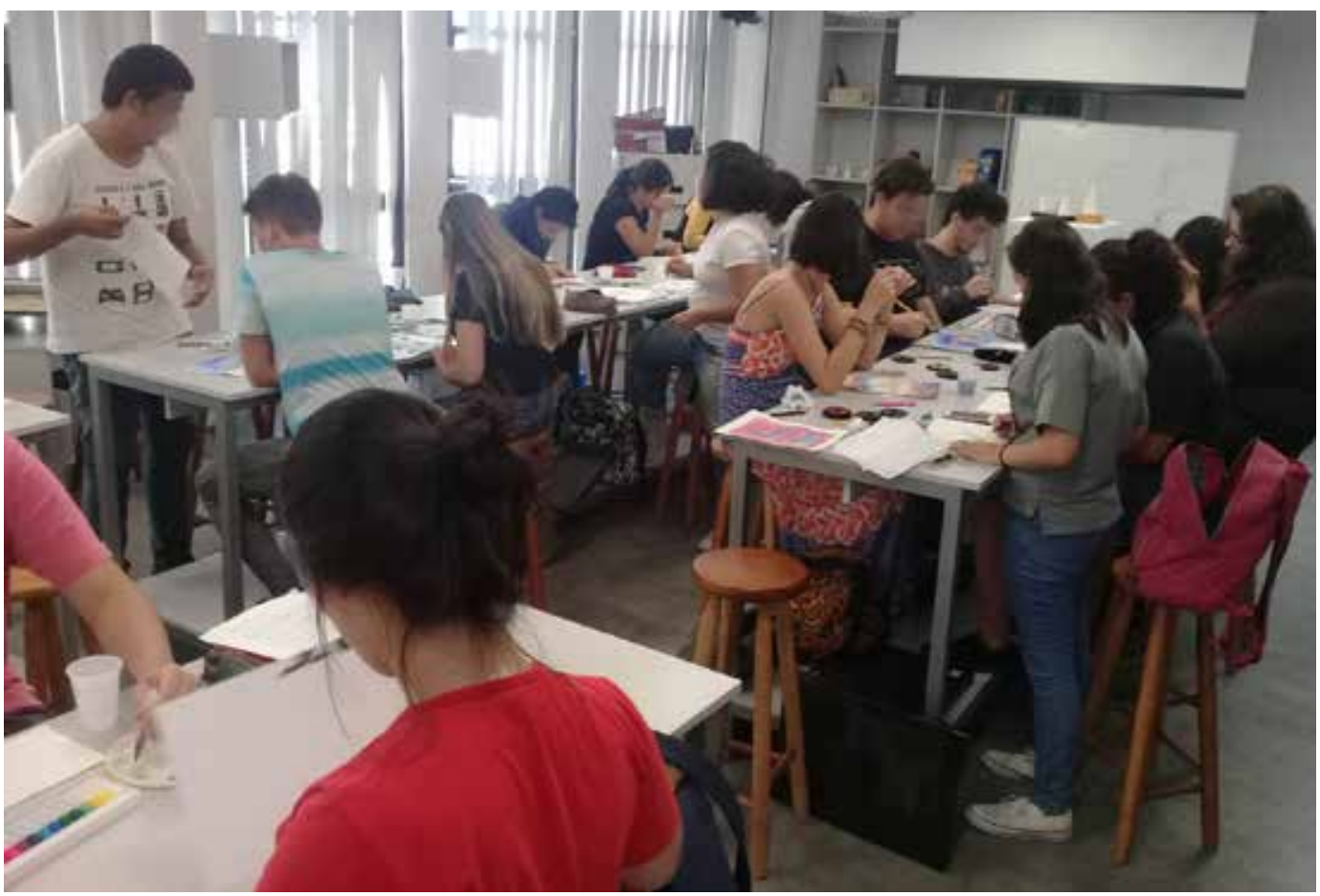

Fig. 4.1 - primeiro grupo do Estudio de Desenho, início do semestre. Fonte: acervo do autor.

2 Desenho Livre é uma disciplina do primeiro período do curso de Design da ESPM RJ, na ocasião, não lecionada por mim. 
de ter um espaço semanal em que eles pudessem se obrigar a desenhar algo, sem a pressão de um professor que os estivesse avaliando. Nomeamos nossa oficina como Estúdio Livre de Desenho, com a proposta de ser um espaço aberto e contínuo de desenvolvimento do desenho, em que os alunos pudessem estar semestre após semestre enquanto quisessem. Combinamos que eu não seria um professor ali, mas um tutor que até poderia ensinar coisas, mas que principalmente mostraria referências e lançaria ocasionalmente desafios.

No segundo encontro, já com a turma dividida, propus ao primeiro grupo, inteiramente composto por novos alunos, que retomassem o tema da aula regular (desenho de observação de sólidos), porém vários fizeram uma expressão de má vontade, então sugeri que a partir da proposta do professor fizessem algo livre, proposta que os agradou. Alguns estudantes pediram ajuda para desenhar as proporções de um objeto em relação ao outro, outros pediram ajuda para fazer uma gradação de tons de grafite, e assim seguimos até que um aluno perguntou se poderia usar aquarela, pois sempre quisera estudar essa técnica. Quando respondi que sim, ele tirou as tintas e pincéis da pasta e começou a explorar a aquarela. Pouco depois, uma colega de sala sentou-se ao lado dele e pediu um pincel emprestado para experimentar também. Dei algumas dicas sobre preparação do papel e das tintas, que foram ouvidas por mais dois alunos interessados, e fui ajudar uma menina que não conseguia fazer sombras em formas esféricas.

Pouco depois, voltando ao grupo de aquarela, vi que uma aluna estava ensinando ao grupo como fazer degradês e como fazer fusão de cores, o grupo estava aprendendo
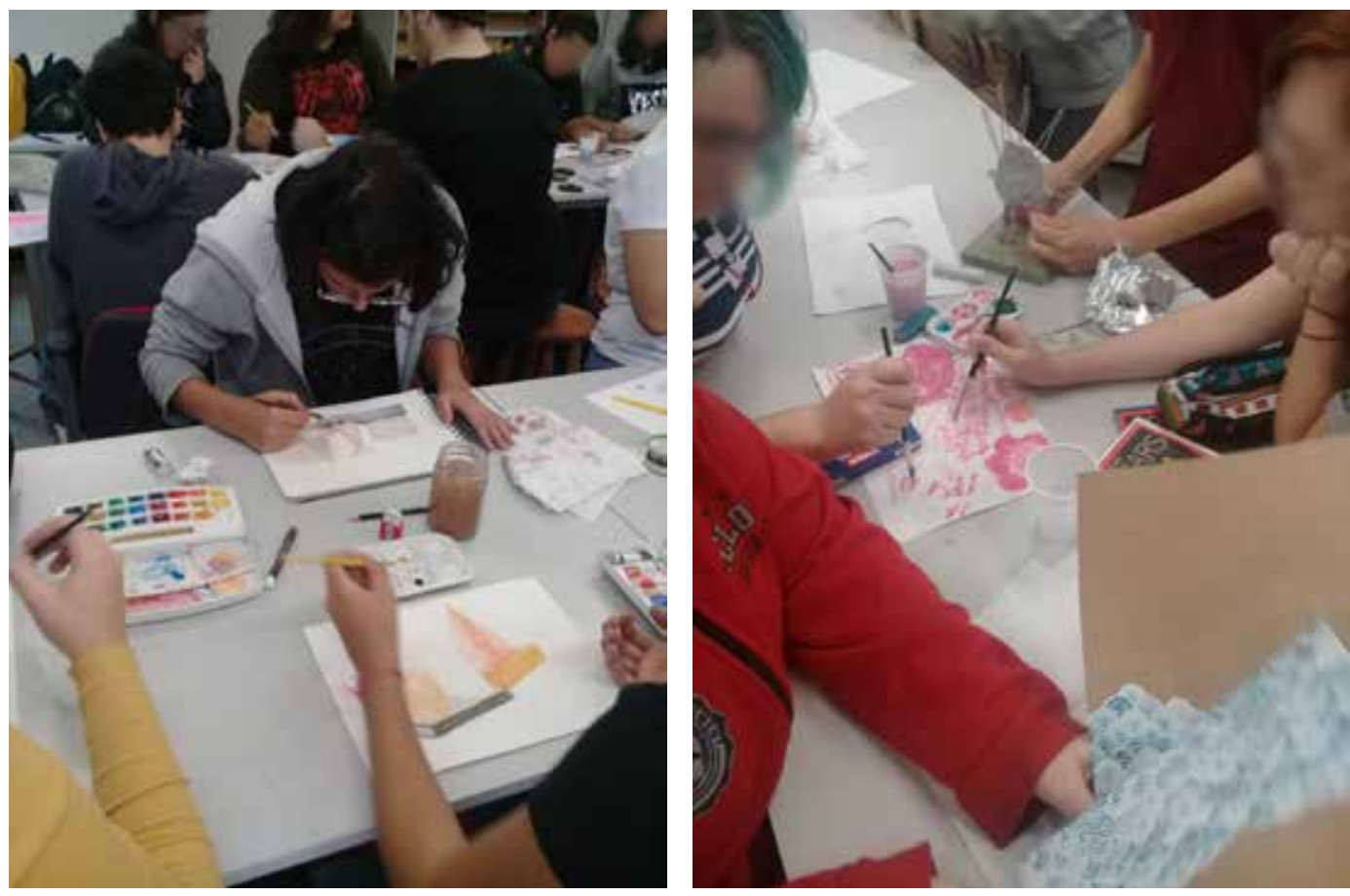

Fig. 4.2 - Alunos aprendendo aquarela uns com os outros: demonstração e observação.

Fonte: acervo do autor. 
por sua conta. Esse aprendizado por pares tornou-se constante no Estúdio Livre. A partir da intensa colaboração que havia experimentado na Cidade Submarina, decidi que valorizar o aprendizado por pares seria a base do Estúdio Livre de Desenho.

Segundo Dale (1969, apud Thalheimer, 2015), a retenção das informações aprendidas se dá segundo uma pirâmide em que na base estão estímulos e atividades de aprendizagem mais práticas e no topo estão as mais abstratas. A retenção aumenta conforme as atividades se tornam mais práticas e imersivas. O nível mais baixo do cone de Dale nos diz que experiências propositivas diretas proporcionam a maior taxa de retenção do que foi aprendido, e nessa categoria podemos incluir as atividades de ensino. Em interpretações atuais do cone de Dale, vemos um percentual de $90 \%$ de retenção de informações quando se faz algo na prática ${ }^{3}$. O Estúdio Livre de Desenho era muito mais imersivo e significativo que as aulas regulares de Desenho Livre pois os estudantes estavam desenvolvendo pontos de interesse pessoal relacionados a técnicas, materiais ou temas, assim o aprendizado por pares estava sendo muito eficaz e os estudantes demonstravam muita empolgação e grande desenvolvimento.

Após alguns encontros, perce-

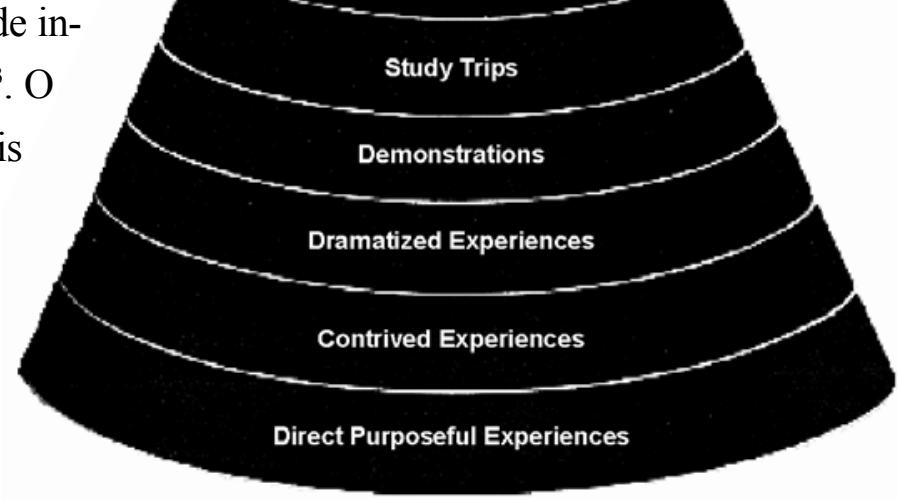

Fig. 4.3 - Cone do conhecimento na configuração original de Edgard Dale (1969, apud Thalheimer, 2015). Fonte: reconstrução do autor a partir de https://www.worklearning. com/2015/01/05/mythical-retention-data-the-corrupted-cone/ bi que algo muito interessante estava acontecendo: além dos grupos formados por alunos poderem aprender por conta própria, havia uma mobilidade entre os grupos movida pelo interesse dos participantes. Quem em uma semana estava num grupo desenhando rostos podia na semana seguinte ter se juntado a outro grupo que explorava lápis de cor na tentativa de pintar um rosto que havia desenhado.

Fomos ao Museu Nacional de Belas Artes. A galeria das estátuas apresenta várias moldagens em gesso que eram no passado objeto de estudo dos acadêmicos de Belas Artes. Já estávamos em nosso décimo encontro e tínhamos um grupo constante de cerca de 12 a 15 estudantes que já não se dividia em dois horários, aos poucos os do primeiro horário foram ficando mais tempo e os do segundo horário

3 Não incluímos as pirâmides de aprendizagem mencionadas porque não encontramos embasamento teórico para os percentuais nelas exibidos, encontramos artigos dizendo que tais percentuais não são confiáveis (Thalheimer, 2015). 


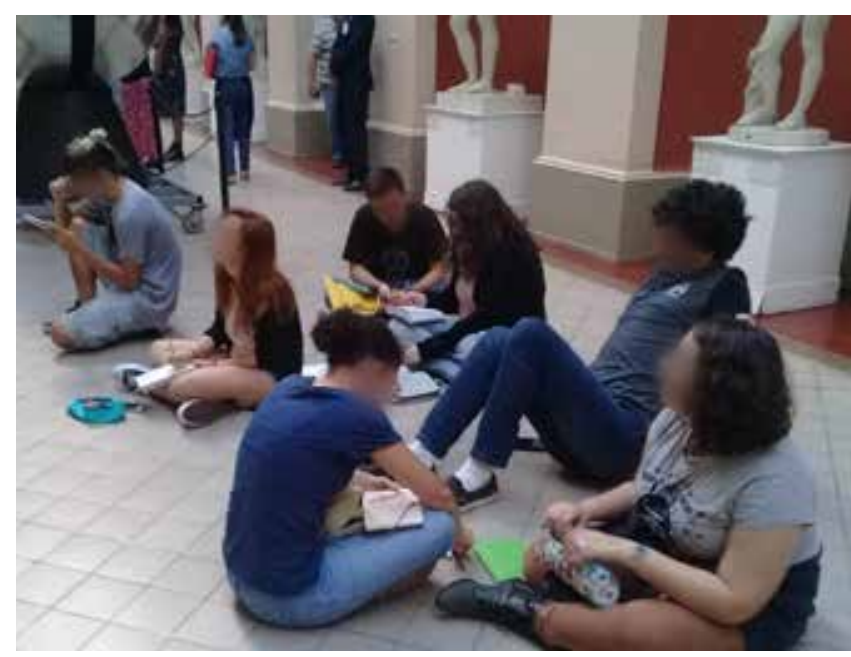

Fig. 4.4 (à esquerda) -Visita ao Museu Nacional de Belas Artes, 2018.1. Fonte: acervo do autor.

Fig. 4.5 (abaixo) -último encontro do Estudio de Desenho em 2018.1. Fonte: acervo do autor.

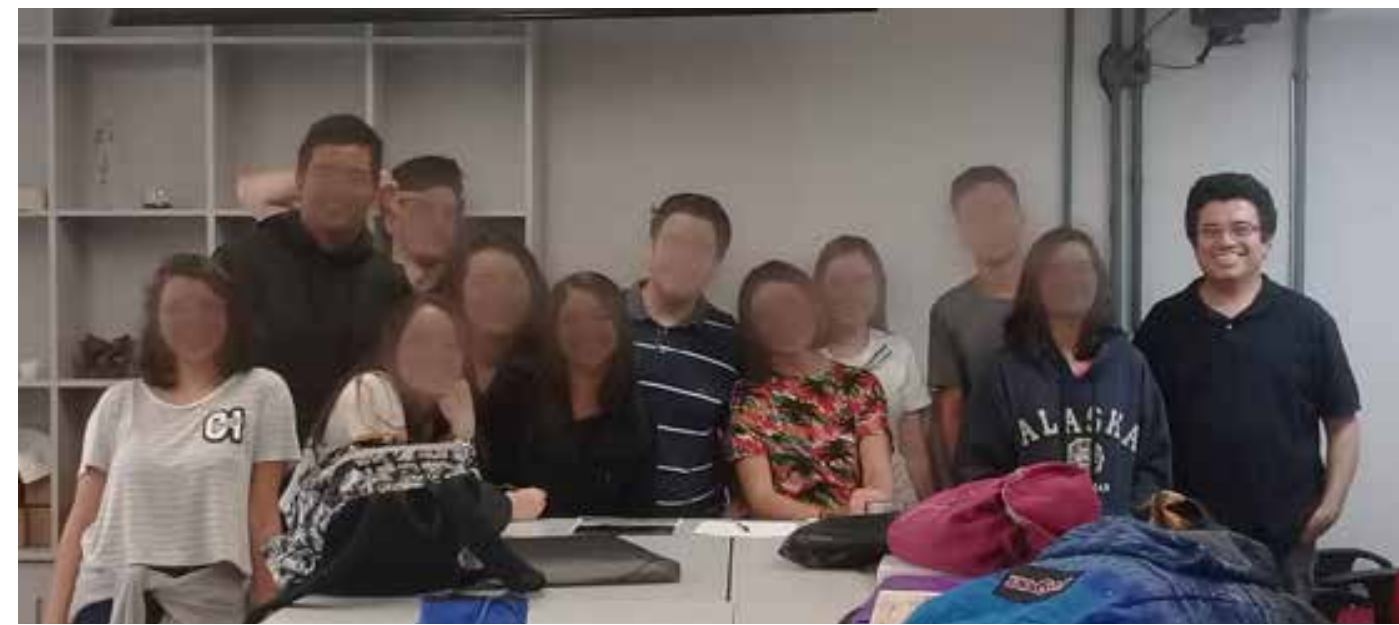

foram chegando mais cedo, e todos estavam participando das $14 \mathrm{~h}$ às $17 \mathrm{~h}$ e alguns traziam amigos de outros cursos da ESPM. Participaram alguns estudantes de Cinema, de Publicidade e mesmo de Administração.

Descobri que o desenvolvimento colaborativo das atividades do Estúdio de Desenho guardava muitos pontos em comum com a teoria dos grupos operativos (Pichón-Rivère, 1986), e que seria importante observar seu funcionamento à luz daquela teoria.

\section{2}

\section{Sobre Grupos Operativos}

Grupos operativos de ensino são grupos de trabalho em que têm objetivos, problemas, recursos e conflitos que são estudados e considerados pelo grupo à medida que vão aparecendo (Bleger, 1998).

Os grupos operativos são grupos de estudantes com interesses comuns e se baseiam na troca de conhecimentos e no aprendizado coletivo que advém desse compartilhamento. São, portanto, grupos de ensino e de aprendizagem, onde todos podem ensinar e aprender. Segundo Bleger (1998), nos grupos de ensino não há um grupo que assume o papel de ensinar enquanto outro assume o de aprender. 
Nesses grupos, o professor assume um papel de coordenador, ou mediador, e deve interferir na menor medida possível nos caminhos de aprendizagem do grupo, nunca impondo tarefas ou aulas no modelo tradicional.

Há subgrupos que se formam segundo interesses comuns de aprender algo, e são esquemas mutáveis e dinâmicos, que no momento seguinte podem se reorganizar para aprender algo diferente. Os integrantes incorporam e manipulam os instrumentos de indagação. $\mathrm{O}$ autor realça ainda o quanto nesse sentido o clima de liberdade é imprescindível.

Deve-se assim respeitar o que emerge do grupo, que corresponde ao que a cada momento o que o grupo pode admitir e elaborar. Desse modo a ansiedade no aprendizado pode se manter equilibrada, pois um nível baixo de ansiedade poderia indicar a ausência de desafios e um nível alto demais indicaria desafios elevados, ambas situações constituiriam bloqueios ao funcionamento do grupo.

A teoria dos Grupos Operativos de Pichón-Rivère (1986) menciona a espiral da ansiedade, ou do conhecimento, ao considerar que para cada tarefa realizada há uma pré-tarefa a ser superada, relacionada a medos e angustias. Ao superar a pré-tarefa, o grupo engaja-se na tarefa e dá um salto no aprendizado. Interessante é notar que a teoria da aprendizagem significativa de Ausubel (1963) também trata de uma espiral de aprendizagem, e nela a evolução se dá quando algo que foi ensinado tem significado para o estudante, conectando-se às suas estruturas cognitivas para produzir um novo conhecimento que o faz predispor-se a aprender mais. Relacionando as duas teorias a partir das espirais de conhecimento / aprendizagem, podemos inferir que o aprendizado significativo é uma superação de pré-tarefa, de medos e angústias.

A partir dessa inferência, ao considerarmos o grupo operativo como uma força maior que o indivíduo, com o intuito de levar os membros se ajudarem e resolverem seus problemas juntos, vemos que são potencializadores do processo de aprendizagem significativa.

Os grupos operativos não devem ter sua operatividade ou rendimento forçados, deve-se considerar que a cada momento trabalham dentro de sua capacidade. Podem, assim, se organizar e desorganizar, crescer ou diminuir, e a heterogeneidade faz parte de sua estrutura.

O coordenador do grupo deve procurar facilitar o diálogo e motivar as ações do grupo, respeitando sua produtividade, sem querer centralizar as informações e decisões. Os grupos operativos têm por objetivo o enriquecimento pessoal e interpessoal de seus participantes.

O Estúdio Livre de Desenho foi elaborado como um experimento colaborativo inspirado nos grupos operativos, estudando este modelo de aprendizagem como um modelo aberto e inovador calcado na motivação intrínseca de seus participantes. 


\section{3 \\ Estúdio de Desenho 2018.2 - observação e reflexões}

No segundo semestre de 2018 realizou-se a segunda aplicação do experimento Estúdio Livre de Desenho, em que fui observador participante.

Para realizar a observação contei com um bolsista do programa Jovens Talentos, da ESPM, Rafael Mesquita ${ }^{4}$, que participou do Estúdio de Desenho no semestre anterior. Criamos uma marca para o Estúdio e uma programação de atividades para o semestre, que incluía workshops e uma agenda de saídas externas para desenhar.

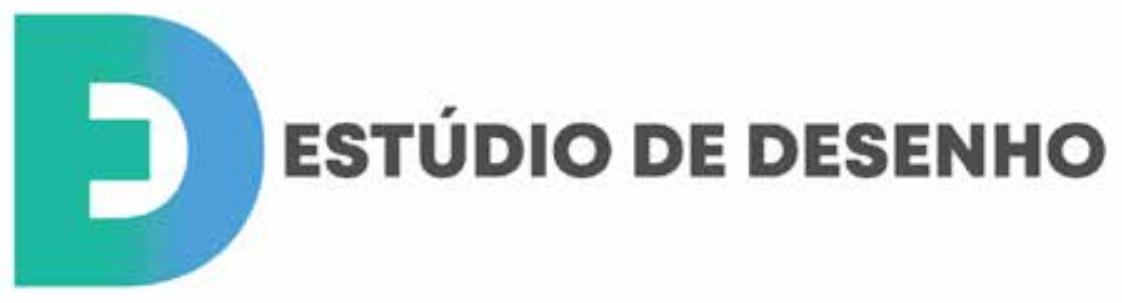

Fig. 4.6 - Marca criada pelo Rafael para o Estúdio. Fonte: acervo do autor.

O Estúdio de Desenho passou a acontecer às sextas-feiras e não éramos dois grupos dessa vez, passamos a ter um só horário de reunião, de 14:30 às 17 horas, e na prática alguns alunos chegavam antes desse horário e outros ficavam além.

Enquanto Rafael participava da maioria dos encontros e ia relatando o dia-a-dia do Estúdio, observei que alguns alunos assumiam o papel de líderes de mudança e propunham atividades ao grupo, como saídas para desenhos externos, músicas, temas para os encontros. Uma dessas alunas foi a Laura Trompowsky, do quinto período, que pediu para me substituir em alguns dias em que precisei me ausentar, garantindo o funcionamento do grupo.

Observei que as frequentes interrupções dadas pelo grande número de feriados causaram menor comprometimento dos alunos esse semestre em relação ao anterior. Houve menos alunos constantes, mas os que havia operaram segundo o mesmo modelo, trocando informações e ensinando uns aos outros.

A teoria do Grupos Operativos de Pichón-Rivère (1986) menciona a espiral da ansiedade, ou do conhecimento, ao considerar que para cada tarefa realizada há uma pré-tarefa a ser superada, relacionada a medos e angústias. Ao superar a pré-tarefa, o grupo engaja-se na tarefa e dá um salto no aprendizado. Interessante é notar que a teoria da aprendizagem significativa de Ausubel (1963) também trata de uma espiral de aprendizagem, e nela a evolução se dá quando algo que foi ensinado tem significado para o estudante, conectando-se às suas estruturas cognitivas para produzir um novo

4 ESTÚDIO LIVRE DE DESENHO, pesquisa do programa Jovens Talentos (bolsa pré-PIC) de Rafael de Sousa Mesquita (ESPM / NIP, 2018) 
conhecimento que o faz predispor-se a aprender mais. Relacionando as duas teorias a partir das espirais de conhecimento / aprendizagem, podemos inferir que o aprendizado significativo é uma superação de pré-tarefa, de medos e angústias.

A partir dessa inferência, ao considerarmos o grupo operativo como uma força maior que o indivíduo, com o intuito de levar os membros se ajudarem e resolverem seus problemas juntos, grupos operativos são potencializadores do processo de aprendizagem significativa.
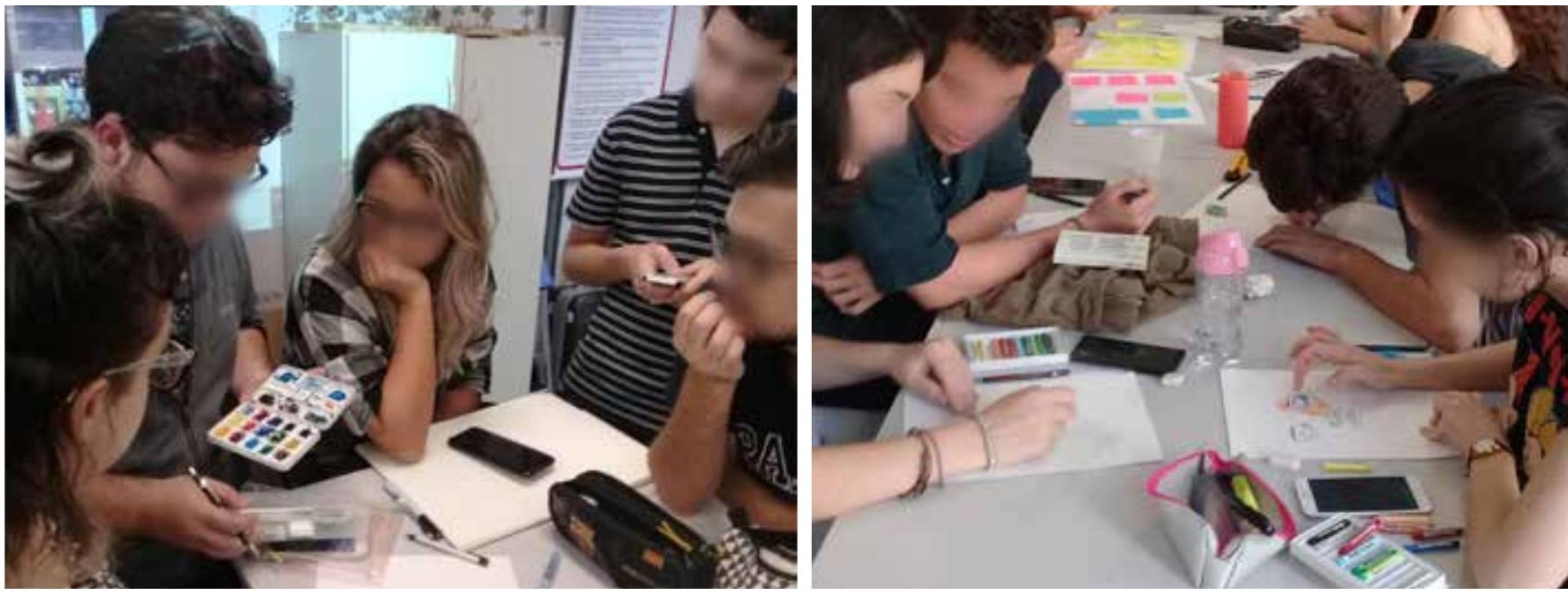

Figs. 4.7 e 4.8 - Grupos de autoaprendizagem: Gabriel Miguez ensinando aquarela (esquerda) e

Gabriela Calbar experimentando pastéis (direita). Fonte: acervo do autor.

Com relação às atividades programadas, conseguimos encaixar algumas palestras e workshops numa semana de profissões da ESPM, a Week Up. A coordenação do curso pediu sugestões e indicações e aproveitei a oportunidade.

Tivemos as seguintes palestras durante o evento: Desenho para Tatuagem, Escultura em Papel como Ilustração, Urban Sketchers ${ }^{5}$, Ilustração. Consegui também dois workshops, um de colagens em papel, outro de colagens digitais.
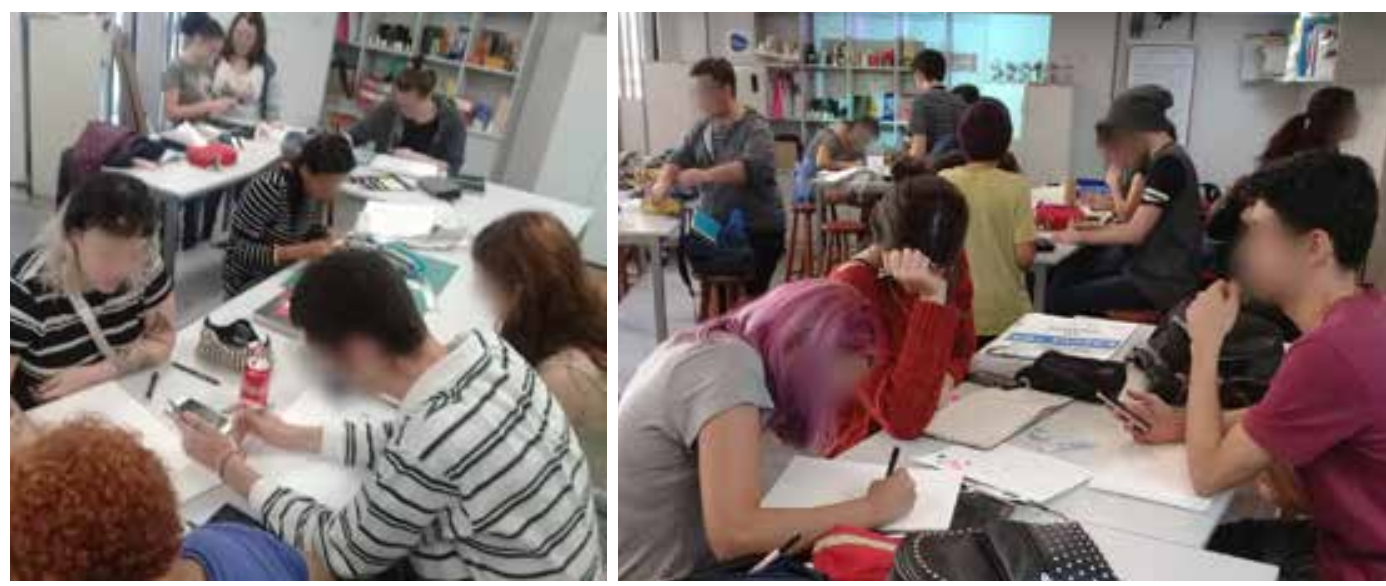

Figs. 4.9 e 4.10- Encontros do Estúdio de Desenho em 2018.2. Fonte: acervo do autor.

5 Movimento mundial de desenhistas que retratam cenas cotidianas a partir do esboço instantâneo, sem fotografias, réguas e mesa, o desenho é capturado na hora. 
Os workshops e palestras relacionados com desenho e criação manual foram muito bem aceitos e com bom número de estudantes presentes. Eu fui a todos e Rafael esteve presente em vários e relatou ter ouvido das pessoas presentes que os eventos foram super interessantes.

Fizemos duas saídas desenhadas, fomos ao zoológico do Rio e ao palácio do Catete. No zoológico foram dezoito estudantes da ESPM e um de outra faculdade, convidado por um dos nossos alunos, e no Palácio do Catete foram quinze estudantes.
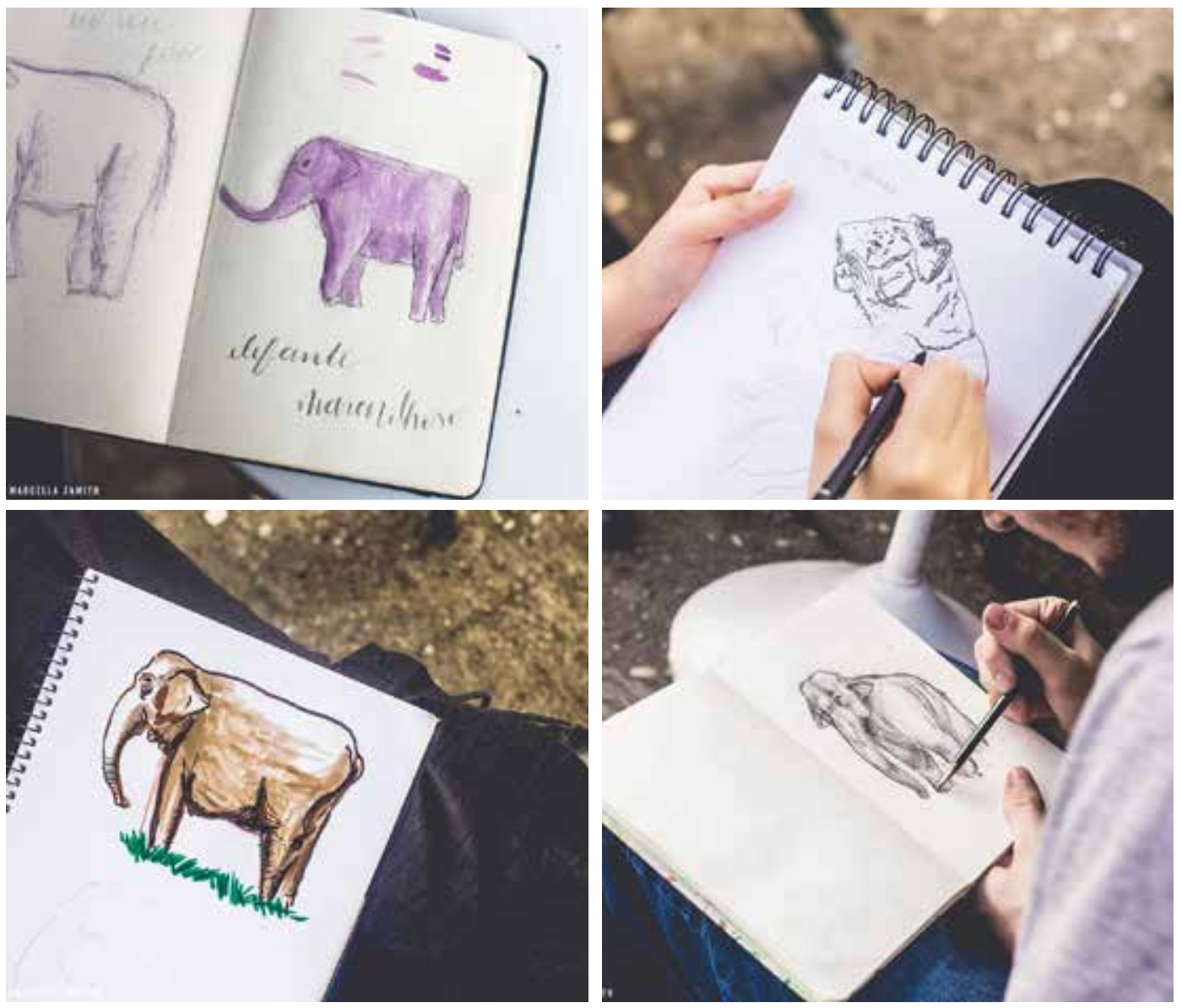

Figs. 4.11, 4.12, 4.13 e 4.14 - Desenhos no Zoo. Fotos Marcella Zamith.

No zoológico os alunos se agruparam por tema, de acordo com os animais e houve boa troca de experiências, técnicas e materiais. A aluna Marcella Zamith, do primeiro período, levou uma câmera profissional e fotografou os colegas.

Como essas duas "expedições" foram em locais grandes e abertos, com parques, os alunos se dividiram em pequenos grupos e se espalharam. Desenhei um pouco e circulei observando os grupos menores. No Palácio do Catete, reparei que nesses grupos poucos estavam desenhando, na maior parte dos casos um ou dois estudantes desenhavam e os demais observavam. Conversando depois com eles, disseram que tinham grande dificuldade em fazer desenhos de áreas abertas, de observação, que não tinham feito isso nas aulas de Desenho Livre e sentiam-se inseguros. 

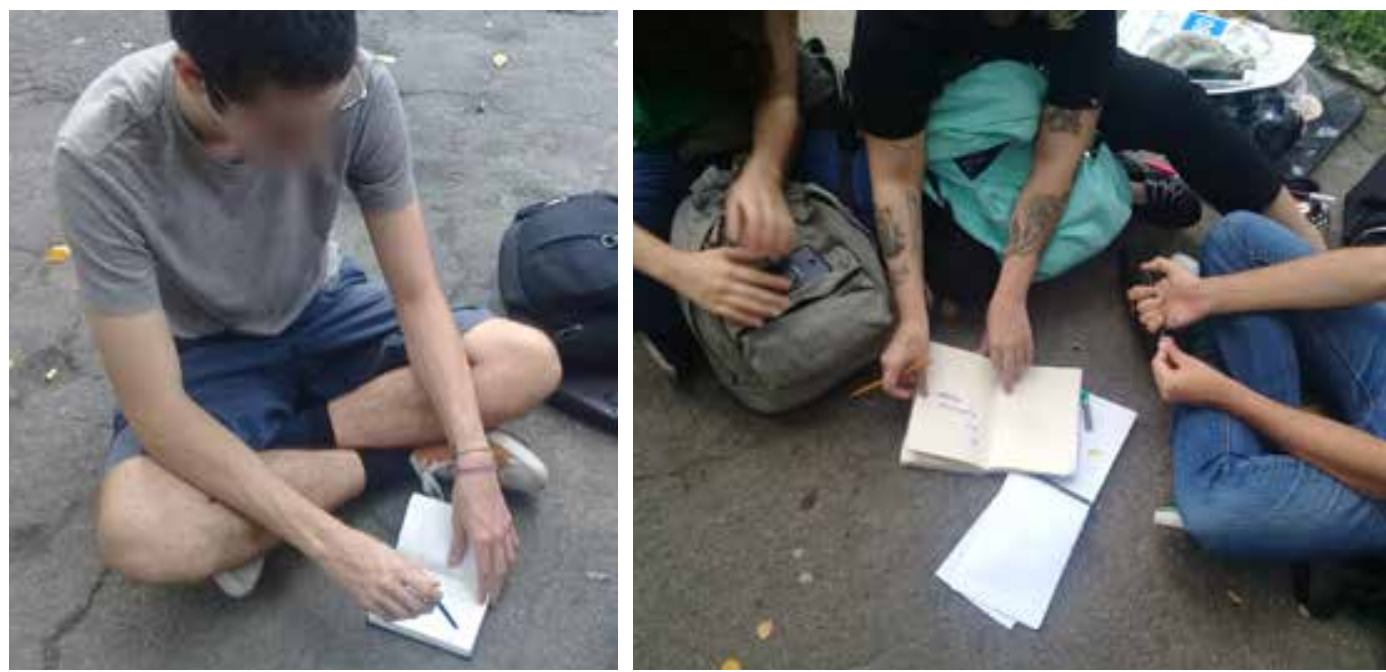

Figs. 4.15 e 4.16 - Desenhos no Museu da República. Fonte: acervo do autor.

A Laura tinha assumido um papel de monitora e circulava pelas reuniões do Estúdio com grande desenvoltura, opinando e ajudando os colegas mais que desenhando. Ela e outros ficavam à vontade para escolherem músicas.

Certo dia de outubro, Laura descobriu um canal do Youtube com vídeos de modelos vivos, colocamos para passar no projetor da sala e todos ficaram desenhando, Laura deu várias dicas para alguns alunos com dificuldade em fazer o desenho do corpo em pouco tempo, pois as poses eram de no máximo cinco minutos. Desse dia até o final do semestre, quase metade dos participantes interessou-se em desenhar modelos projetados a partir desse canal, Croquis Cafe.

Programamos também um terceiro evento externo, para o final do semestre: desenho em mesa de bar. Esse evento foi inspirado no Feijão Ilustrado, evento que era organizado por ilustradores cariocas em que desenhavam completamente os papéis que cobriam as mesas. Essa saída foi na última semana de aula e não deu certo pois a turma havia escolhido um bar ao ar livre próximo da escola e choveu logo após termos chegado. Conversamos um pouco e nos dispersamos.

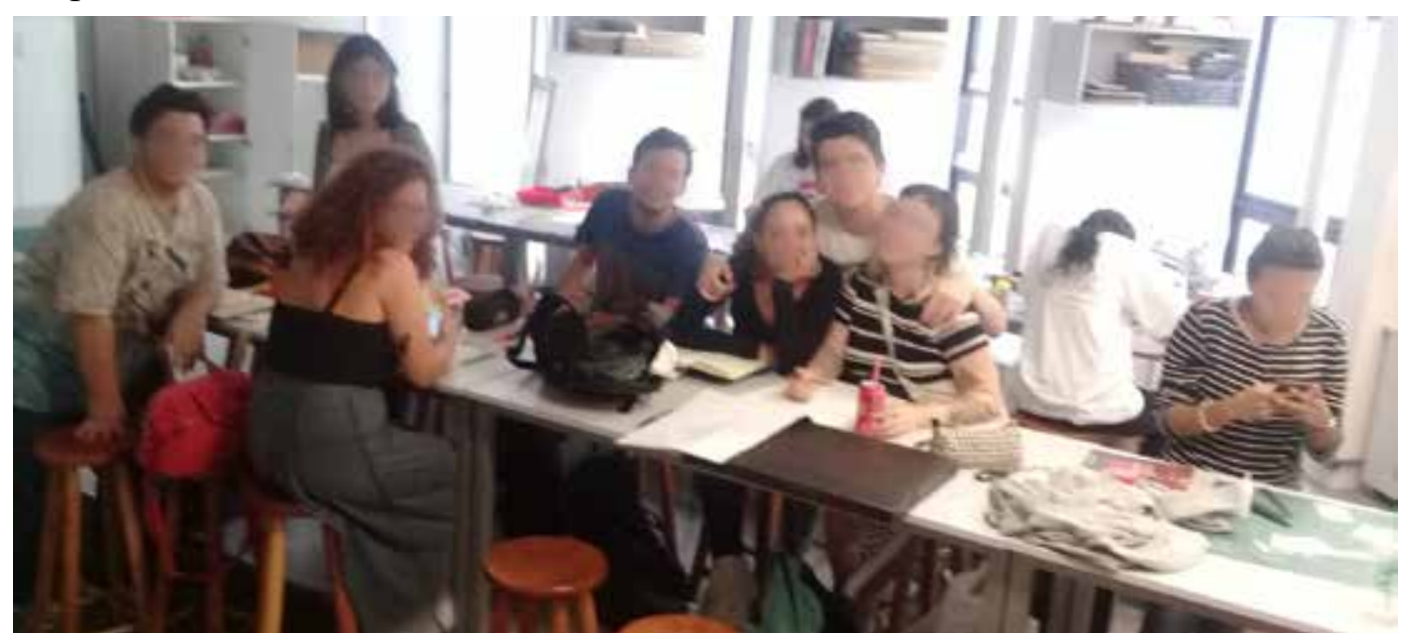

Fig. 4.17- Última reunião de 2018.2. Fonte: acervo do autor. 
Rafael conversou informalmente com sete alunos que participaram dos encontros do Estúdio de Desenho nesses dois semestres de 2018. Transcrevo a seguir o que Rafael considerou mais importante na fala de cada um deles.

O Estudante 1 disse que o Estúdio de Desenho foi importante para o desenvolvimento pessoal, já que no Estúdio era possível tirar tempo para os projetos que não conseguia fazer em casa, o fato de ter um horário reservado para desenvolvimento pessoal ajudou a criar uma rotina e ter mais foco nos projetos pessoais. Além disso, apontou a dificuldade de saber quando o Estúdio acontecia por causa da constante mudança de dias ocasionada pelos feriados.

Estudante 2 ressaltou o fato de poder ganhar horas complementares para fazer os seus projetos pessoais como um importante ponto, e que o Estúdio é interessante por ser um espaço bem livre, sem exigências e que as saídas de desenho são muito legais para não ficar apenas na sala de aula.

Para a Estudante 3, o Estúdio foi importante para o aperfeiçoamento de habilidades de desenho, além de ter conhecido outras pessoas. $\mathrm{O}$ fato do professor ser atencioso foi ponto destacado pela entrevistada. Além disso, a entrevistada falou que seria interessante o professor sugerir novas coisas a serem aprendidas e levar alguns materiais diferentes para experimentação.

O Estudante 4 destacou a iniciativa da faculdade reservar um tempo para desenvolvimento das habilidades de desenho dos alunos, além de falar sobre a troca de conhecimentos com os demais participantes. Sugeriu também que o estúdio deveria agregar estudantes de mais cursos e que poucas pessoas conhecem o Estúdio.

A Estudante 5 mencionou que é interessante a faculdade ter o Estúdio de Desenho e que se interessou por achar que o desenho vai ser muito importante para sua profissão como designer. Também falou que a absorção de conhecimento realmente acontece e que sentar perto de pessoas que sabem mais que você é muito interessante. Falou que poderia ter mais saídas de desenho.

O Estudante 6 disse que ter um dia para desenhar é importante para o desenvolvimento dessa habilidade, pois a prática é muito importante. Também disse que a troca de experiência entre os alunos é importante, já que muitos alunos têm estilos diferentes de desenho e dominam materiais diferentes. Apontou que as saídas de desenho são legais por mudar o ambiente e isso amplia as possibilidades dos alunos.

A Estudante 7 apontou o fato do Estúdio ser um lugar bem livre e criativo, que o professor ajuda bastante e ao mesmo tempo busca não interferir muito nas produções dos alunos. Foi dito também que a dinâmica da oficina flui muito bem e que as saídas também funcionam.

Cabe dizer que os alunos pediram para criarmos um grupo de mensagens pelo aplicativo Whatsapp, de modo que todos pudessem ser avisados sobre mudanças de 
dias dos encontros, já que muitos feriados caíram nas sextas-feiras e em algumas dessas semanas nos encontramos nas quartas-feiras.

\section{4 Estúdio de Desenho 2019.1 - observação e reflexões}

A partir do que foi observado nos semestres anteriores, introduzi algumas modificações e aprimoramentos que fizeram com que o Estúdio de Desenho fosse sensacional no primeiro semestre de 2019.

O bom desempenho foi também favorecido por eu ter passado a lecionar a disciplina de Desenho Livre, o que permitiu uma grande conexão com os estudantes, e uma plena visão do conteúdo da disciplina. A partir disso, foi possível conduzir o Estúdio como uma atividade complementar com muito mais segurança.

Como no semestre anterior havíamos criado o grupo de mensagens, nas ferias postei eventos relacionados a desenho, como encontros de Urban Sketchers e exposições. Alguns alunos pediram para nos encontrarmos e combinamos uma visita desenhada ao Parque Lage. Poucos compareceram a essa visita, seis alunos apenas, mas por estarmos no período de férias, achei incrível o interesse deles e percebi o quanto já estavam se apropriando do Estúdio e dele sentiam falta.

Logo que começaram as aulas nos reunimos, como no semestre anterior, às sextas-feiras, e com a maioria de participantes do primeiro período. Criamos, a pedido dos participantes, uma conta do Instagram, aplicativo de compartilhamento de imagens, para compartilharmos desenhos e fotos deles desenhando.

Alguns alunos disseram ter ouvido dos colegas que tínhamos ido ao Museu de Belas Artes, pediram para irmos novamente. Nessa nova visita, fomos em um grupo de cerca de vinte alunos e passamos a tarde desenhando nas galerias. Dois estudan-

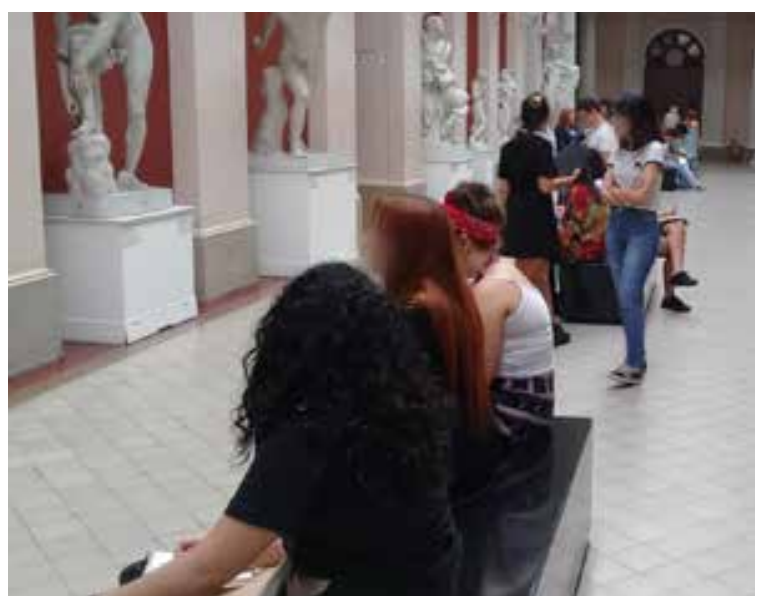

Figs. 4.18 e 4.19 - Visita ao MNBA.

Fonte: acervo do autor.

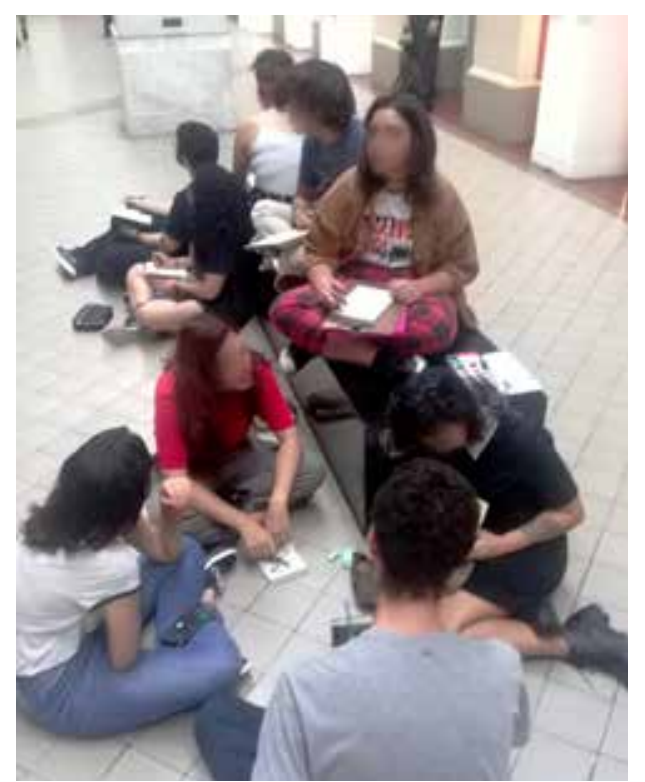


tes de outras escolas se juntaram a nós, e enquanto estávamos lá vários visitantes passavam observando os desenhos e os alunos desenhando. Essa observação dos visitantes não os deixou tímidos como eu receava, achei-os seguros, sustentando os olhares e não parando de desenhar enquanto eram observados.

Nossas reuniões semanais transcorreram normalmente, porém com maior apropriação do espaço pelos estudantes que nos semestres anteriores. Aqueles que eram de períodos mais avançados e frequentavam o Estúdio pela segunda ou terceira vez já escolhiam músicas desde o início, já se sentiam à vontade para opinar ou demonstrar materiais e técnicas aos colegas e passaram a fazer algumas ações coletivamente, o que foi muito interessante.
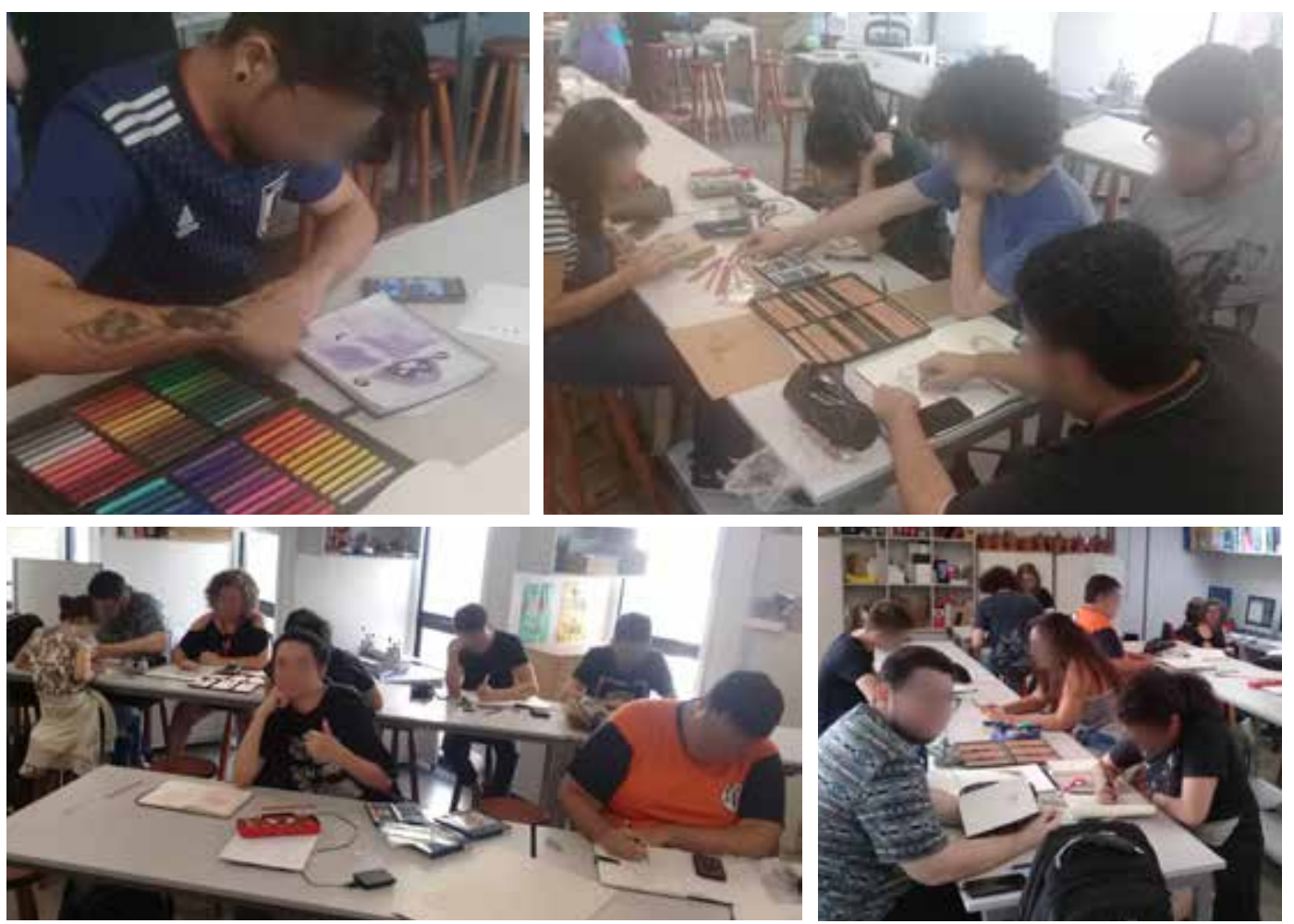

Figs. 4.20, 4.21, 4.22 e 4.23 - Encontros do Estúdio de Desenho. Fonte: acervo do autor.

Algumas vezes encontrávamos a sala um tanto desarrumada e com materiais de outras aulas deixados espalhados pela oficina. Os alunos do Estúdio passaram a organizar a sala e, com a piora da bagunça à medida que o semestre avançava, espalharam cartazes pedindo que todos mantivessem a sala limpa e guardassem os materiais utilizados.

No meio do semestre alguns alunos pediram para irmos a um bar desenhar; combinamos fazer isso num sábado e fomos a um bar no Morro da Conceição. Participaram seis estudantes e dois desenhistas Urban Sketchers, que convidei. Desenhamos o casario ao redor e nos desenhamos.

Houve uma nova semana de palestras e workshops, a Semana de Talentos. Nessa semana os alunos da ESPM Rio deveriam apresentar talentos seus e fiquei muito feliz em saber que vários alunos que participavam do Estúdio de Desenho en- 

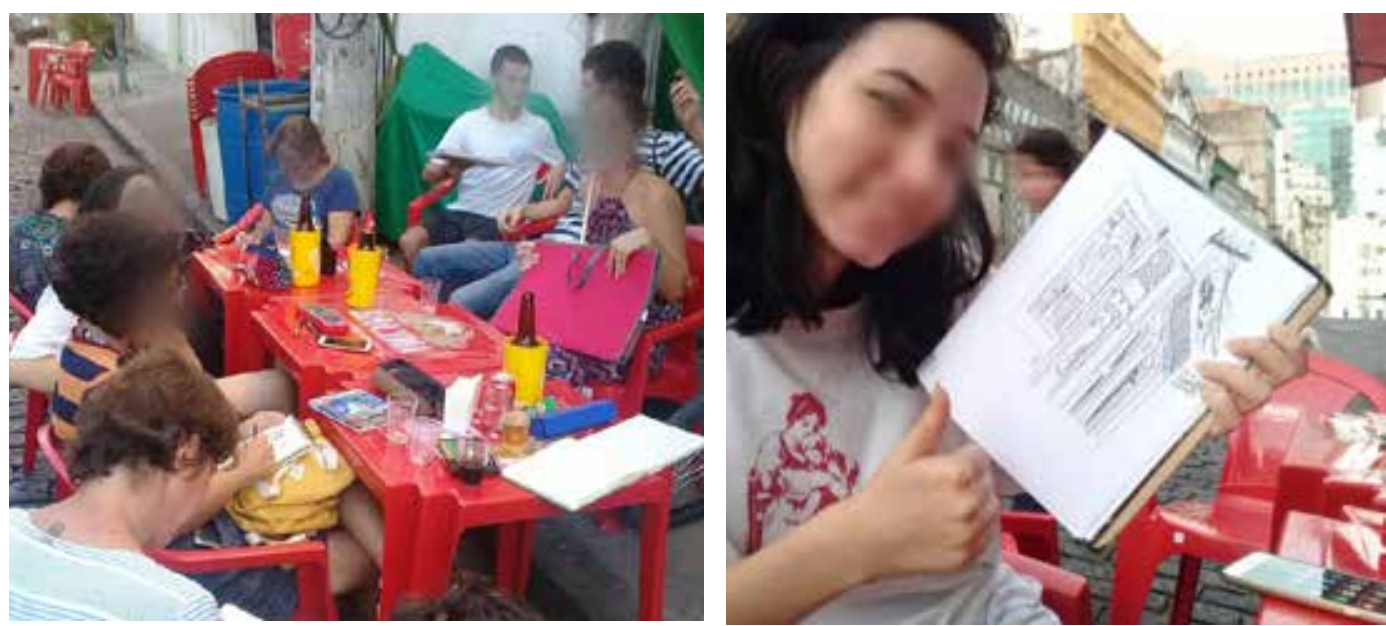

Figs. 4.24 e 4.25 - Desenhando no Morro da Conceição. Fonte: acervo do autor.

viaram desenhos para serem expostos. foram tantos desenhos que a organização do evento optou por não imprimi-los, para que não precisassem fazer uma seleção, mas projetá-los nas paredes de duas salas. Ficaram três projetores em cada sala dessas exibindo continuamente os desenhos dos alunos. Após a semana de talentos, dois conjuntos de trabalhos foram selecionados para ficarem expostos nos corredores da escola, do Vitor Lanzarini e da Julia Kürten, ambos alunos do terceiro período de Design, ficaram o semestre todo e lá ainda estavam no meio das férias seguintes.

$\mathrm{Na}$ semana de talentos tivemos novamente palestras e eventos afins, uma palestra sobre a vida de ilustrador, com Carlito Machado, outra de arte urbana, com o aluno e grafiteiro Igor Nunes, uma de Caligrafia, do professor Claudio Gil, e uma de projetos pessoais artísticos com o designer Rafo Castro. Tivemos também um workshop de demonstração de materiais de desenho Molotow.

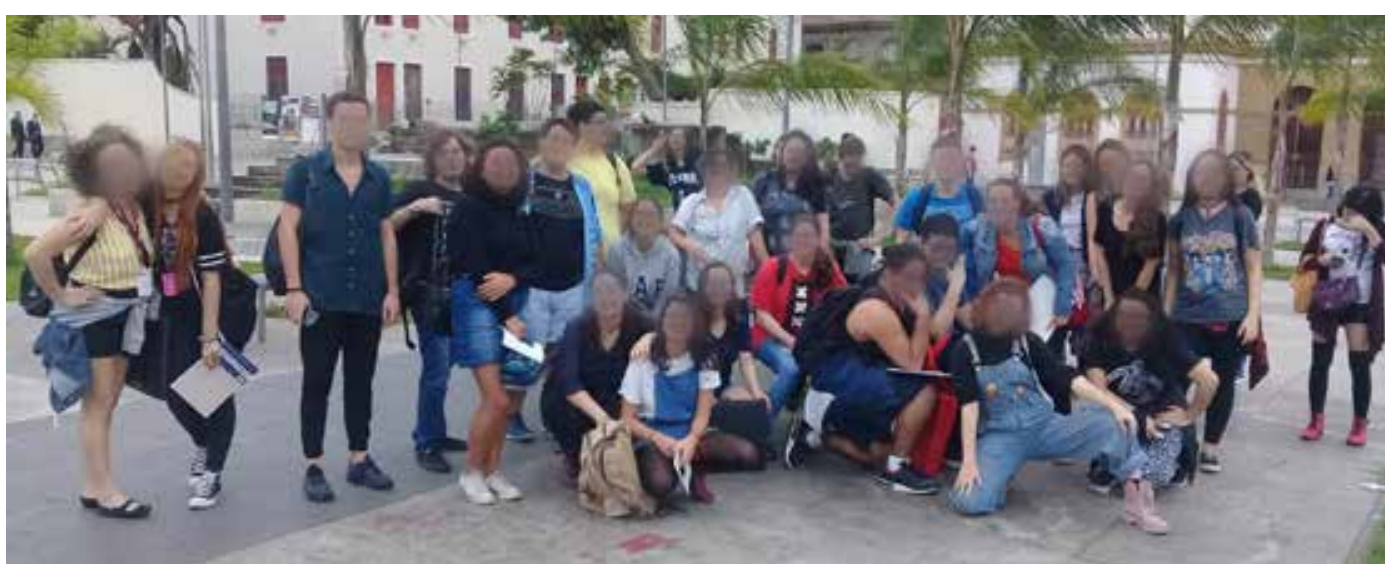

Fig. 4.26 - 49 estudantes foram ao Boulevard Olímpico para desenhar na semana de talentos. Fonte: acervo do autor.

Utilizamos a Semana de Talentos para uma outra saída de desenho, dessa vez aberta e divulgada a toda a ESPM. Fomos ao Boulevard Olímpico desenhar e participaram quarenta e nove estudantes, a maioria de Design, mas houve alunos de Administração, Publicidade e Cinema nesse dia. Ficamos a manhã toda desenhando por ali e ao término da atividade alguns alunos do Estúdio de Desenho 
pediram para continuarmos desenhando na rua. Escolhemos uma rua perto da ESPM, onde fica a Associação Comercial do Rio, e lá também houve pessoas observando e mesmo fazendo perguntas aos estudantes, que me pareceram muito confiantes e seguros.
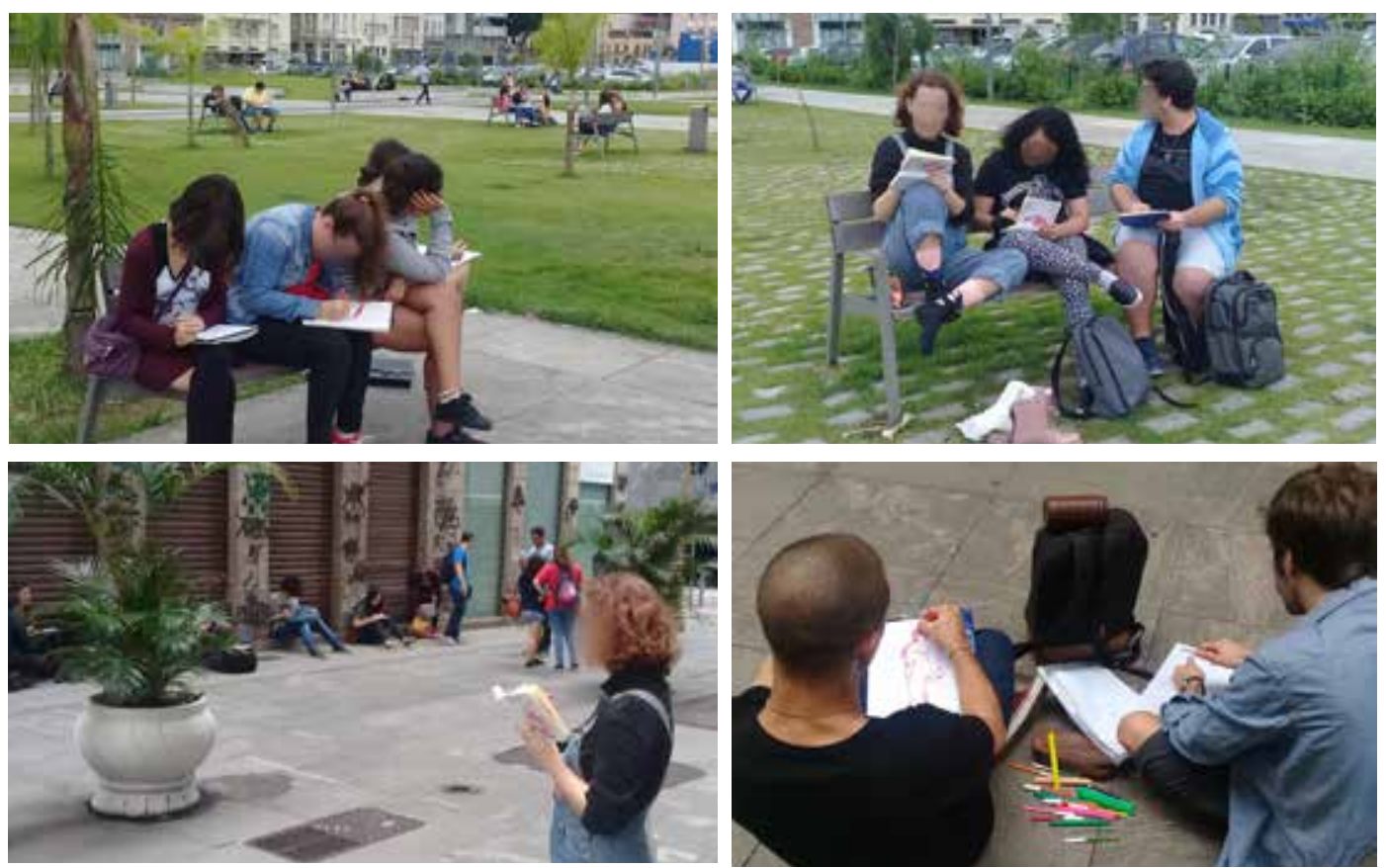

Figs. 4.27, 4.28, 4.29 e 4.30 - Desenhando na semana de talentos. Fonte: acervo do autor.

Além dessas saídas, atendendo a sugestões dos alunos conseguimos alguns materiais de desenho para o Estúdio: lápis pastéis, pastéis secos e pastéis oleosos, materiais que não são normalmente utilizados no curso e geraram grande interesse na sua experimentação o semestre todo.

A Laura não pôde mais participar pois estava estagiando. Assim que ela deixou de frequentar o Estúdio, o papel de monitora voluntária - ou líder de mudança, como definido na teoria dos Grupos Operativos - passou imediatamente a ser assumido pela aluna Larissa Vidal, do primeiro período.

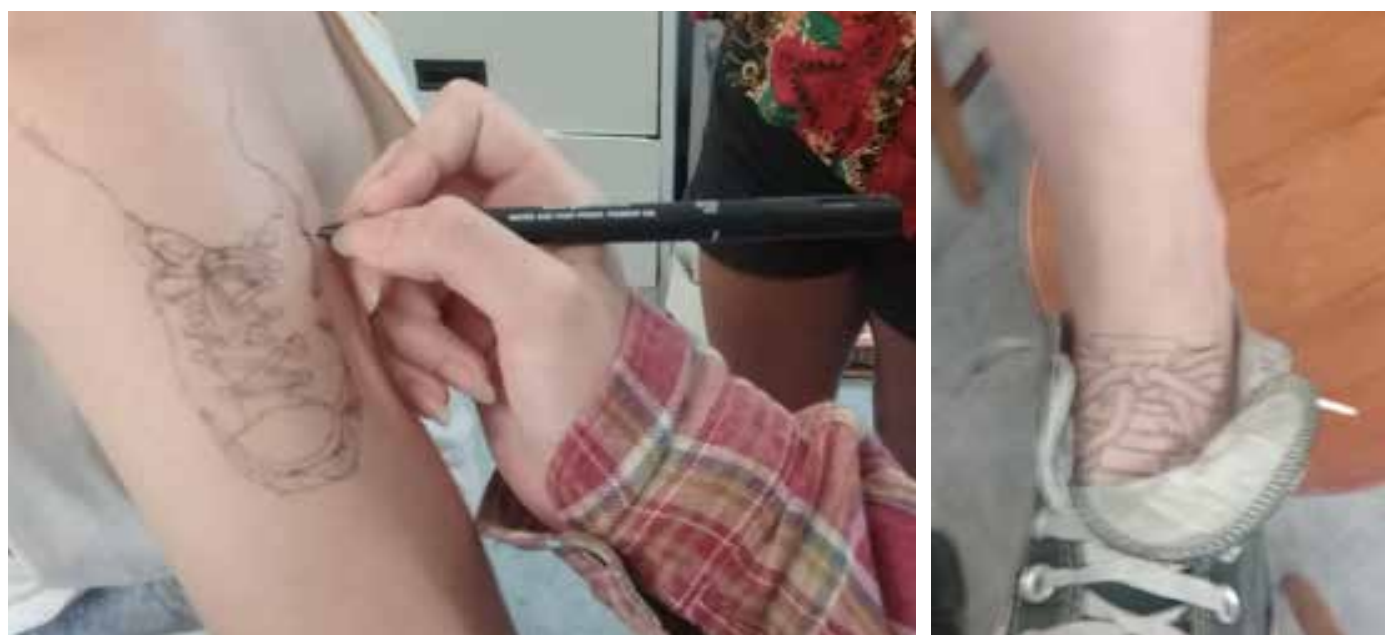

Figs. 4.31 e 4.32 - Último encontro 2019.1: desenhando uns nos outros. Fonte: acervo do autor. 
Os alunos que participaram do primeiro semestre do Estúdio de Desenho estavam agora no terceiro período letivo e foram meus alunos pela primeira vez na disciplina de Projeto 3, que lida com o design de exposições. Comparada com turmas anteriores, tiveram um desempenho muito superior, mostraram-se maduros e criativos e tiveram desempenho similar em todas as disciplinas do período. Surpreenderam o professor de representação tridimensional. Não é possível afirmar que a experiência de participação do Estúdio de Desenho tenha sido responsável por esse desempenho, mas posso dizer com certeza que ela gerou maior envolvimento dos alunos com o curso e com a escola, e desse envolvimento podemos imaginar um melhor desempenho acadêmico.

A partir dessa observação, pude inferir que a próxima turma também deveria ter bom desempenho e que dois semestres depois veria trabalhos ainda melhores, pois além dos alunos terem participado de um Estúdio aprimorado, terão sido meus alunos na disciplina de Desenho (em que comecei a lecionar em 2019.1), e isso pode potencializar seus ganhos. Não quero, com isso, insinuar que o desenho é uma disciplina modificadora, ou melhor que as outras, mas que o ganho em autoconfiança e em autorrealização estão diretamente relacionados ao aprendizado significativo e possibilitam aos estudantes aqueles saltos na espiral de aprendizagem de Ausubel (1963), mencionados no início desse capítulo.

Tais inferências se concretizaram, as turmas que recebi na disciplina de projeto de exposições no segundo semestre de 2019 e no primeiro semestre de 2020 foram as melhores que cursaram aquele projeto integrado ${ }^{6}$. O nível dos projetos era tão bom que convidamos os responsáveis pelos espaços culturais trabalhados para assistirem às apresentações. Compareceram representantes do Espaço Cultural BNDES e do Museu da Imagem e do Som e o MIS propôs à ESPM concretizar duas das exposições apresentadas em suas instalações.

Imaginei a criação de uma mistura dos experimentos Cidade Submarina e Estúdio de Desenho. Uma atividade inspirada nos grupos operativos baseada em um contexto ficcional em que os participantes pudessem realizar uma imersão, a partir da qual tivessem como objetivo desenvolver representações bidimensionais. O processo de investigação seria individual, porém discutido de forma participativa e a pesquisa seria colaborativa.

Essa proposta foi esboçada como uma disciplina eletiva e é uma das práticas pedagógicas propostas no capítulo final desta tese.

Seria uma disciplina onde os objetivos de ensino / aprendizagem sejam definidos pela taxonomia de Bloom, de estrutura baseada nas Metodologias Ativas

$6 \mathrm{O}$ desenvolvimento do projeto integrado de exposições foi um produto resultante da pesquisa de mestrado do autor: Estratégias pedagógicas no ensino de Design: por uma Metodologia Ativa (2016) 
e na Taxonomia do Aprendizado Significativo de Fink (2007), de funcionamento inspirado nos grupos operativos e orientada não à criação de algo específico, mas ao desenvolvimento inserido em um contexto específico.

Segundo Pichón-Rivére (1986), os grupos mais livres têm mais êxito na qualidade (desenvolvimento) da tarefa, enquanto os grupos mais autoritários têm mais êxito na conclusão da tarefa.

\section{5}

\section{Estúdio de Desenho no Exílio}

o Estúdio Livre de Desenho durante a pandemia de Covid-19 em 2020.

Após os dois semestres de 2019, em que o Estúdio de Desenho cresceu e ganhou mais participantes de diferentes cursos da ESPM, resolvemos investir em planos mais ousados.

Os estudantes criaram uma campanha de divulgação do Estúdio com cartazes, webmails, imagens na tela do hall da escola e banners na área logada dos estudantes. A campanha foi ao ar na primeira semana de aula, em fevereiro, divulgando o início do Estúdio para a sexta-feira da semana seguinte ao Carnaval, a primeira semana de março.

No segundo semestre os estudantes resolveram também pensar em uma exposição de trabalhos em que pudessem vender reproduções e se uniram aos alunos de serigrafia para organizar uma feira de impressos independentes, que aconteceria em maio de 2020. Procurei o Centro Carioca

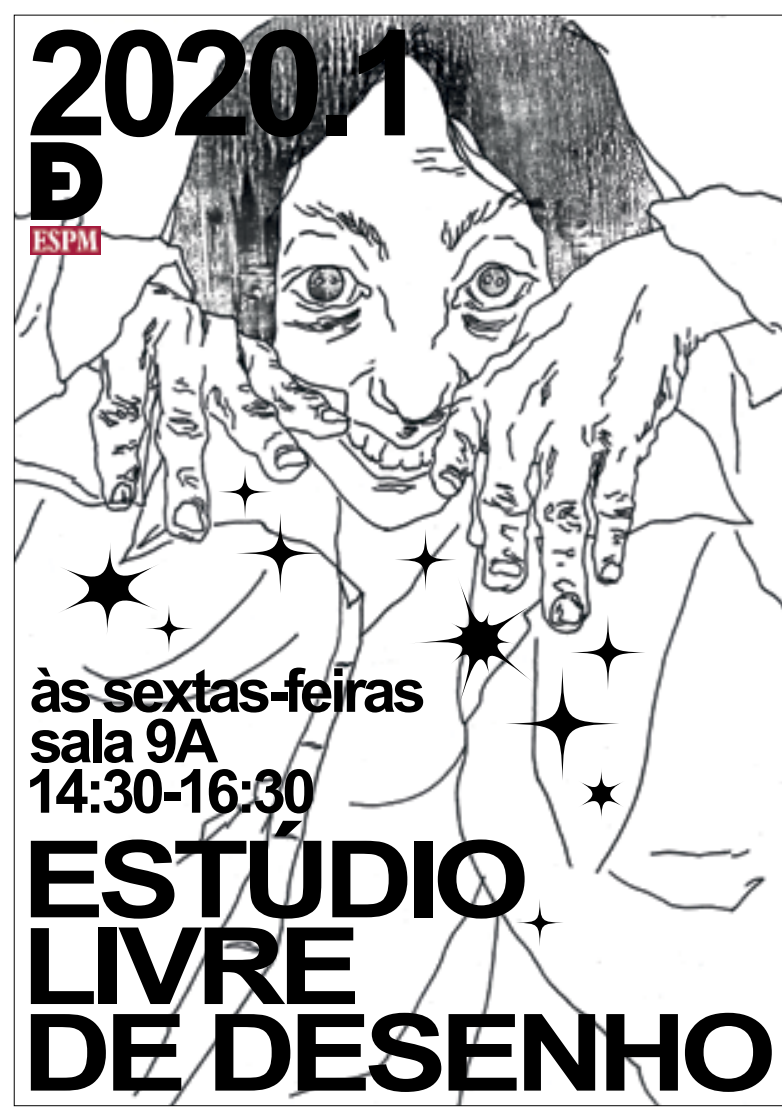

Figs. 4.33 - Cartaz, parte do material de divulgação criado para 2020.1. Fonte: acervo do autor. de Design e consegui o espaço principal do prédio, marcamos a data para um sábado em que aconteceria a feira Tiradentes Cultural, e a nossa feira seria um evento paralelo.

Um grupo de estudantes tomou medidas do local e começou a planejar a exposição, outro escreveu releases de divulgação e abriu inscrições. 
Tínhamos tudo para um ano glorioso, em que o Estúdio de Desenho ganharia o mundo, porém logo na segunda semana as aulas presenciais foram suspensas e as instituições de ensino entraram em quarentena.

Logo na primeira semana de quarentena criei uma reunião recorrente na ferramenta Zoom Meeting e enviei emails a todos os estudantes que participavam com regularidade do Estúdio de Desenho. Encontramos virtualmente e conversamos sobre como poderíamos transformar nossa experiência em algo virtual, à distância. Alguns estudantes sugeriram que cada um desenvolvesse um projeto pessoal e a cada semana trouxesse para mostrar e comentar o andamento, outros sugeriram que definíssemos temas e que transformássemos provisoriamente em aulas mesmo.

Venceu a turma dos projetos pessoais, e assim começamos. Criei uma pasta compartilhada na nuvem para que todos pudessem fotografar o andamento dos trabalhos e gravar em uma pasta com seu nome. Ainda não sabíamos como seria o semestre, sobretudo para aqueles que tinham restrições de equipamentos e de conexão.

Alterei o material de divulgação que havia sido criado e divulguei nos grupos de Whatsapp de todos os semestres de Design. Divulguei no grupo de professores e pedi para divulgarem nos outros cursos de graduação.

Tivemos uma primeira sessão bem cheia, porém os estudantes tinham ficado tímidos e poucos postaram trabalhos na pasta compartilhada. Os que colocaram, gravaram versões finais do desenho, não desenhos em andamento, e disseram que fizeram assim por vergonha de mostrar publicamente algo que não estava pronto ainda. Propuseram a criação de um grupo no Whatsapp, para troca de mensagens instantâneas. Criamos o grupo, cadastramos todos e convidamos outros que não tinham podido vir.

A maioria dos participantes do Estúdio de Desenho deixou de frequentar os encontros via zoom. Perguntei a alguns o porquê disso e disseram que não estavam mais conseguindo ter a troca que tinham antes e que o estúdio virtual tinha se tornado um canal de exibição de quem era muito bom, e isso inibia quem não se julgava tão bom assim, pois trazia muita exposição.

\section{Repensando...}

Havia nesse modelo um grande risco de perdermos a colaboração e a troca. Pensando nos recursos disponíveis e em como manter os êxitos (autoaprendizagem, autorrealização) obtidos no modelo presencial do Estúdio, resolvi modificar completamente o funcionamento.

Imaginei reuniões virtuais com três momentos:

1 - Apresentação e comentários do que haviam feito ao longo da semana - 
esse momento permitiria exibição de conquistas nos projetos pessoais dos estudantes e troca de informações sobre como os trabalhos tinham sido feitos.

2 - Atividade de desenho prática, proposta pelos participantes - atividade de desenho coletiva, ao longo da qual poderíamos ir conversando e refletindo, relevante aos participantes porque seria proposta e aceita por eles.

3 - Comentários sobre os desenhos feitos - troca de informações sobre detalhes e processos dos desenhos.

$\mathrm{Na}$ semana seguinte, ao perguntar o que tinham feito naquela semana, fui abrindo as imagens deles e pedindo para comentarem processos de desenho, materiais utilizados e ideias. Essa se tornou uma atividade inicial, de aquecimento, com cerca de meia hora de duração e nela os estudantes foram ficando mais à vontade e passaram a perguntar e debater.

Após algum tempo, pedi que sugerissem alguma atividade de desenho.

Alguém sugeriu que desenhássemos animais. Procurei um banco de imagem de animais ${ }^{7}$ e passei a projetar imagens por 10 a 15 minutos, compartilhando com todos. Fizemos isso por cerca de uma hora, cada um podendo usar o material e técnica que escolhesse. Enquanto desenhavam, os participantes iam comentando suas dificuldades como: "uau, não consigo desenhar a cabeça de um cavalo" e outros respondiam com dicas sobre como fazer.

Nesses momentos, dependendo da dica, na maioria das vezes podia ser simplesmente falada e não era necessário interromper as imagens, todos continuavam desenhando. Em alguns casos, porém, a exibição das imagens era pausada para que alguém pudesse mostrar em sua câmera ou na tela do seu computador o como fazer. Também conversávamos sobre desenho, trabalho, e a atividade proporcionou reflexão e aprendizagem ao longo de sua execução.

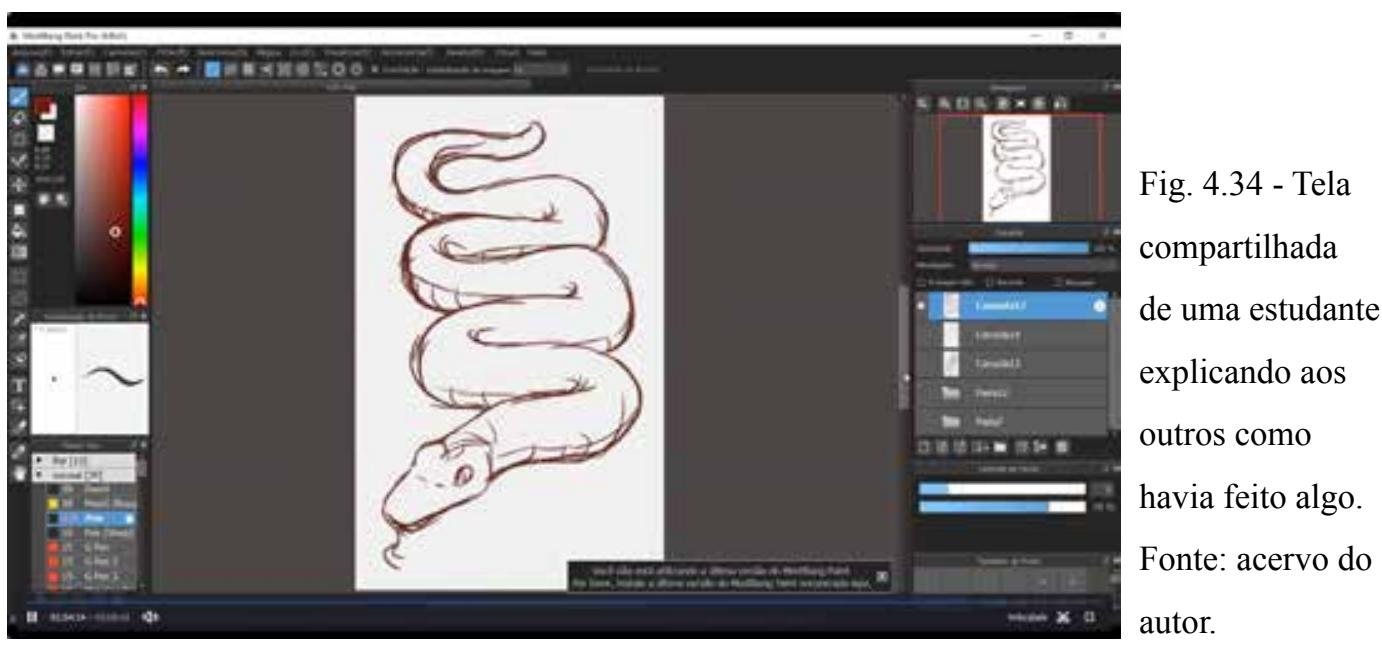

7 https://ine-of-action.com/practice-tools/animal-drawing 
Após isso, pedi a todos que mostrassem seus desenhos em tela ou fotografassem e colocassem os arquivos na pasta compartilhada para vermos.

Essa passou a ser a atividade principal das reuniões do Estúdio de Desenho versão online. Ao longo das semanas os participantes sugeriram diversos temas: desenhar caretas, desenhar uns aos outros, modelos vivos, animais fofos, desenhar a casa de cada um, ilustrar contos literários, criar personagens de RPG, criar personagens para cada um de nós.

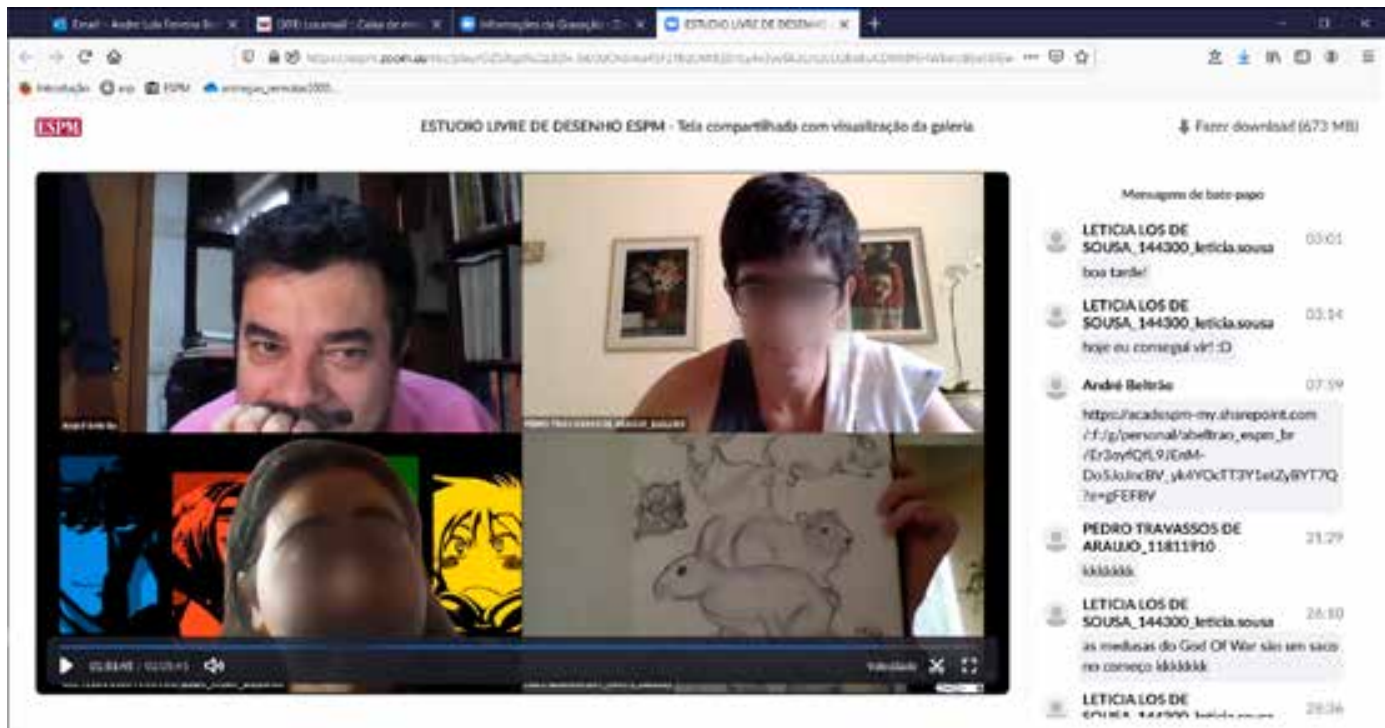

Fig. 4.35 - Momento 3: após desenhar, mostrávamos os desenhos, comentando os processos. Nessa imagem aparecem estudantes das três unidades da ESPM, além de mim. Reunião de 11/09/2020.

Fonte: acervo do autor.

Finalizando, conversávamos sobre esses desenhos da mesma forma que fazíamos no início de cada reunião, comentando técnicas, materiais, forma. Em dado momento no primeiro semestre o grupo sugeriu que criássemos uma conta no instagram para que pudéssemos mostrar os desenhos. Já tínhamos a conta do Estúdio de Desenho ESPM, que era praticamente inativa e passamos a postar alguns trabalhos com o título "Estúdio de Desenho no Exílio".

Os estudantes passaram a repostar seus desenhos publicados e a curtir os desenhos uns dos outros, e por tais postagens não serem avaliativas, pudemos postar desde os trabalhos mais simples e iniciantes até trabalhos super desenvolvidos e de nível quase profissional sem mérito ou demérito.

Tal conjunto de atividades permitiu que o grupo mantivesse sua independência, podendo escolher os temas desejados e usar as técnicas e materiais que preferissem.

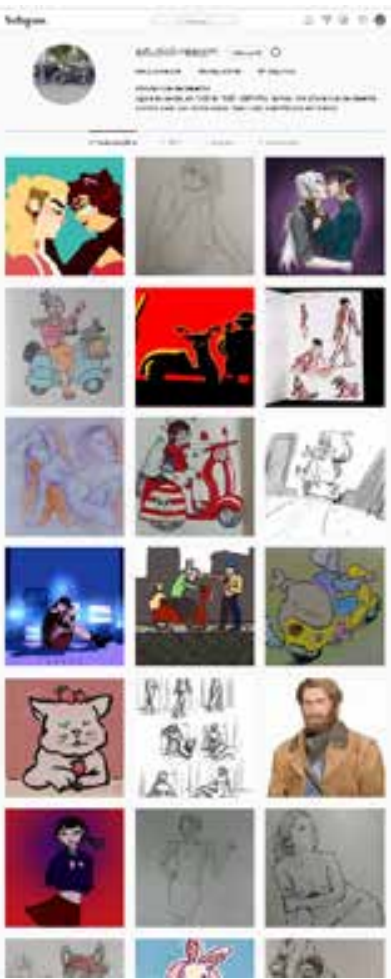

Fig. 4.36 - Instagram.

Fonte: acervo do autor.

8 https:/www.instagram.com/estudiolivreespm/ 

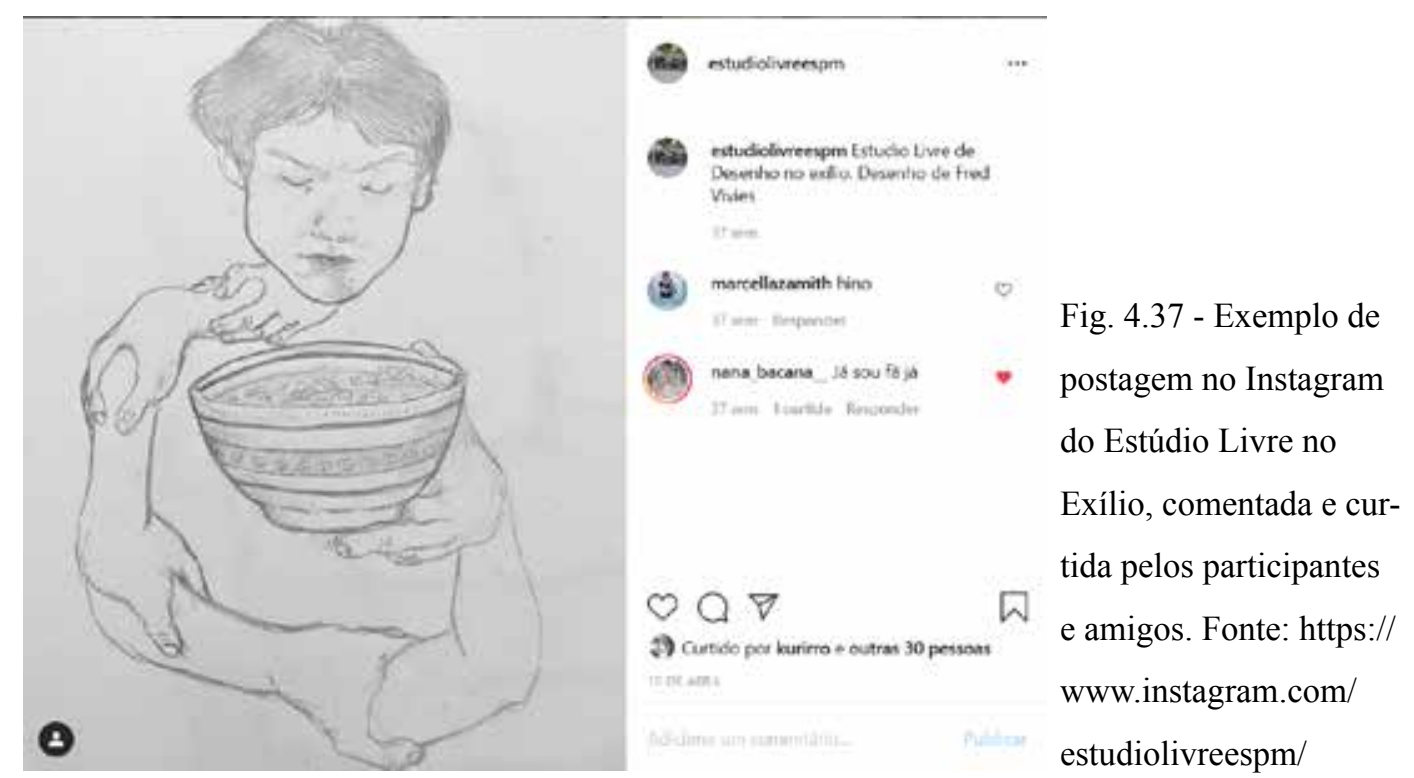

Permitiu que ensinassem uns aos outros pelo exemplo e permitiu que se sentissem desafiados a fazerem coisas diferentes, aprendendo assim pela prática.

No final do primeiro semestre conheci um professor de quadrinhos da ESPM Porto Alegre em uma reunião do zoom e convidei-o a participar. Ele na semana seguinte esteve presente, acompanhado de alguns estudantes daquela unidade.

Daí em diante, até o final do ano, em todas as sextas-feiras nos reunimos em um grupo que contava com a participação de estudantes do Rio de Janeiro e de Porto Alegre. Além de mim, o professor Gio Pereira, de Porto Alegre, também passou a frequentar quase todas as reuniões do Estúdio, bem como a professora Vera Zunino, aqui do Rio.

Apesar de termos conhecido também professores da ESPM São Paulo, somente uma professora participou numa semana e somente um estudante acompanhou-nos ao longo do segundo semestre, mas isso significou a participação simultânea de estudantes das três unidades da escola em algumas semanas.

\section{Férias de meio de ano e o segundo semestre}

Nas férias os participantes do Estúdio pediram que continuássemos nos reunindo. Alguns que tinham se afastado devido ao volume de trabalhos de final de período reforçaram esse pedido dizendo que seria uma nova oportunidade de participarem.

Durante os meses de junho e julho o Estúdio de Desenho se reuniu todas as sextas-feiras. Em três delas eu não pude estar presente e nessas semanas ou o professor de Porto Alegre assumia a condução ou os próprios estudantes se organizavam para que a reunião acontecesse mesmo sem mim.

Os estudantes ganharam autonomia e assumiram a atividade como sua. Senti que, para alguns, nossa reunião semanal tinha algo de terapêutico, de autorreali- 
zação; para outros era como se estivessem adquirindo autoconfiança, alguns aplicavam ali o que tinham aprendido em aulas de pintura digital ou de representação digital; havia aqueles que iam para simplesmente conversar. Essa percepção está diretamente relacionada às categorias da Taxonomia da Aprendizagem Significativa de Fink (2007) - autorrealização, mudança de ponto de vista, integração, relevância, aplicabilidade -, trazendo a percepção de que a aprendizagem significativa acontecia no Estúdio de Desenho, mesmo no modelo online.

Ao longo do segundo semestre de 2020 todos estávamos muito cansados das aulas online e a participação do Estúdio foi caindo levemente a cada semana, até que no final de outubro resolvemos interromper o semestre para que todos pudessem concluir seus trabalhos e marcamos um encontro final para 4 de dezembro.

No dia do encontro final tivemos uma sessão cheia e a atividade proposta foi que nos desenhássemos de surpresa, como presente de natal. Ficamos nos desenhando, cada um conseguiu fazer três ou quatro desenhos e todos fomos retratados. Combinamos encontrar virtualmente em janeiro, nas férias de verão.

$$
\text { Instagram }
$$
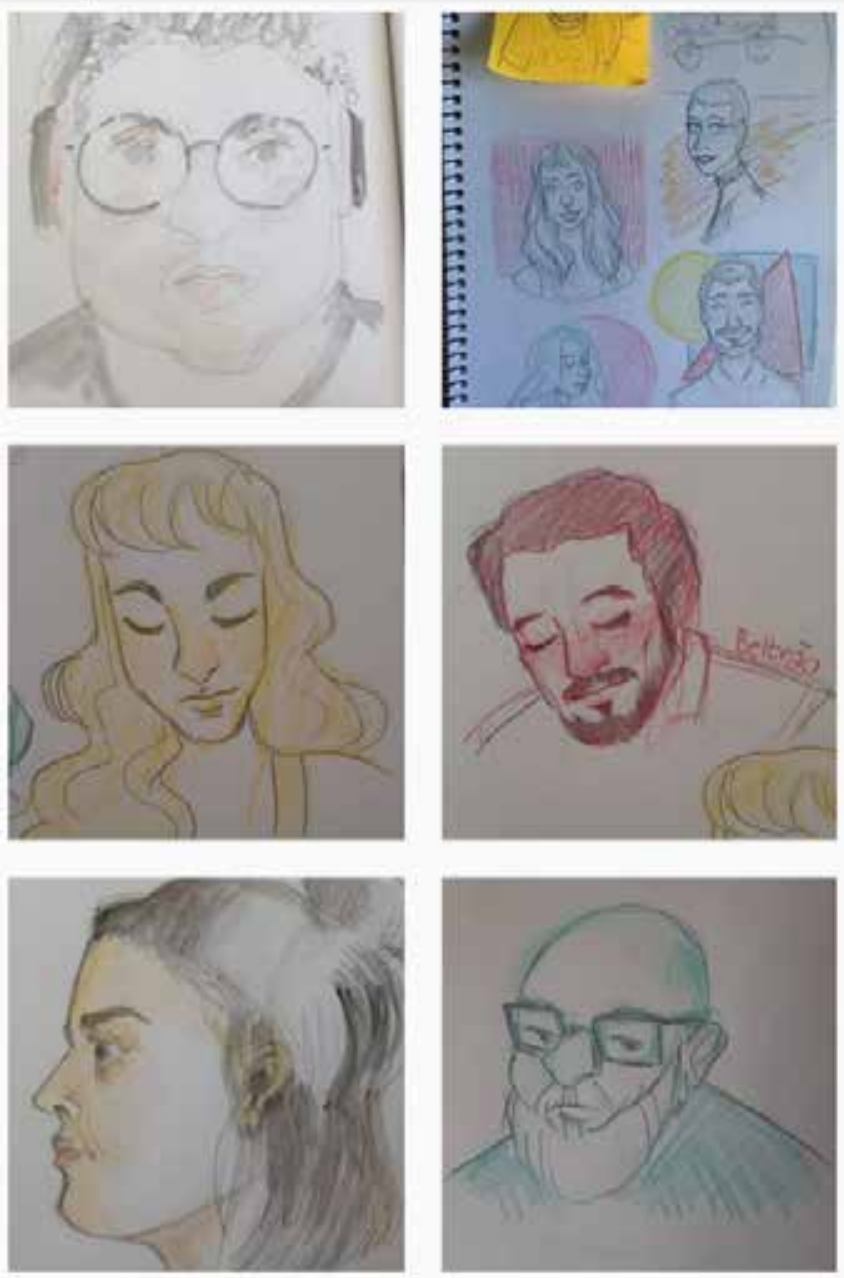

A $\nabla$ (2)
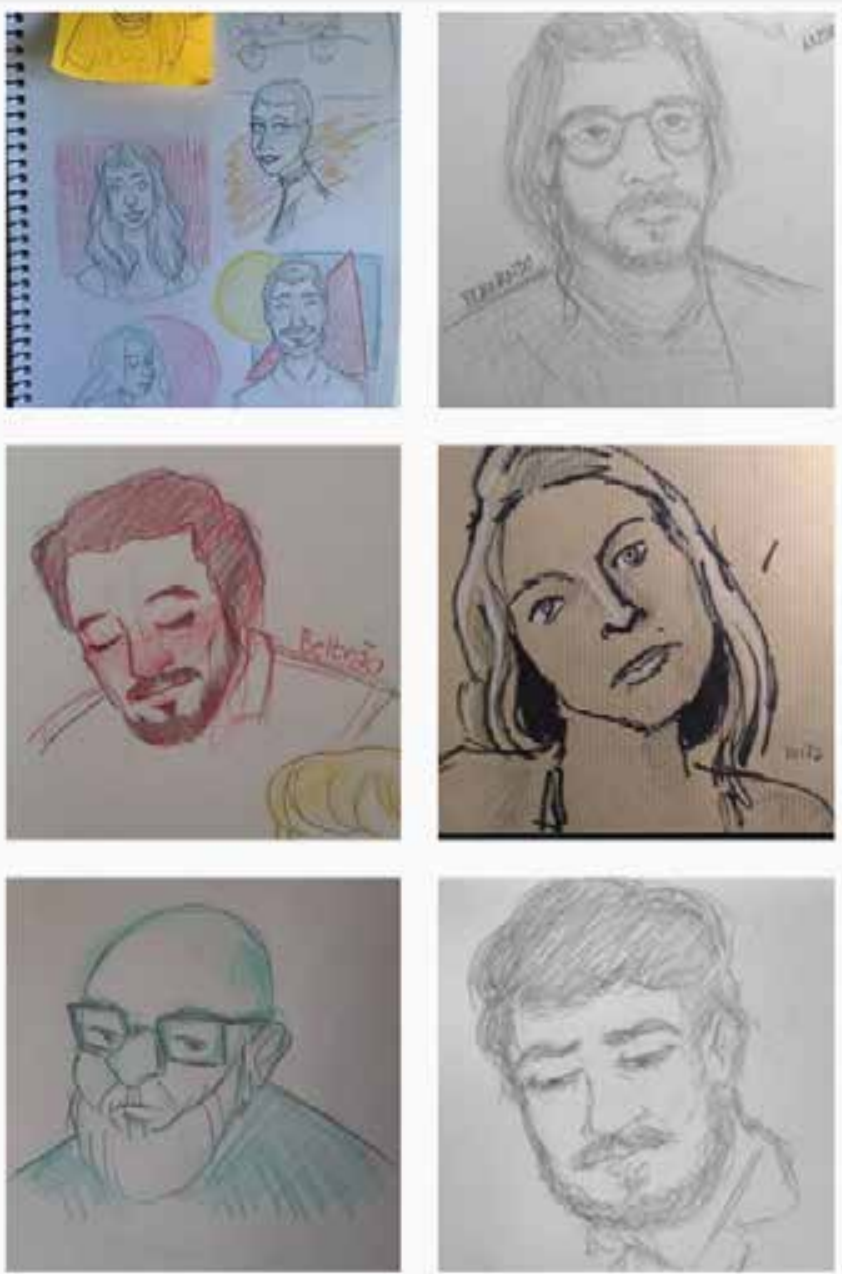

Fig. 4.38 - Postagens do dia 4/12/2020, último encontro do ano do Estúdio Livre no Exílio. Nos posts, alguns dos desenhos que fizemos uns dos outros. Fonte: https://www.instagram. com/estudiolivreespm/ 


\section{Alguns depoimentos}

Consegui colher os depoimentos de quatro estudantes sobre o Estúdio de Desenho no Exílio, que aqui são apresentados pelas iniciais de seus nomes.

1

"Quando o ano começou e eu entrei na faculdade eu achei incrível ter nas sextas-feiras à tarde um tempo em que a gente ficava na faculdade desenhando, porque eu sempre fui muito apaixonada por desenho. Quando fiquei sabendo do Estúdio de Desenho eu falava o tempo todo à minha mãe: caraca, mãe, sexta-feira de tarde a gente fica na faculdade só para desenhar! Eu achava isso muito incrível. Eu acho que o Estúdio de Desenho mesmo com a pandemia foi muito legal. A comunicação que a gente teve com essa galera de Porto Alegre, acho muito que isso pode se manter quando as coisas voltarem ao normal. Gostei muito de ter tido Estúdio de Desenho nas férias de meio de ano também, sempre foi uma distração porque a faculdade é estressante, era divertido ficar lá conversando e desenhando."

Depoimento da estudante A.C., do primeiro período de Design, ESPM Rio

2

"Eu achei fantástico! Não sei se a experiência é só minha, mas entrar em uma faculdade em que é necessário entregar desenhos praticamente toda semana me tirou a diversão em desenhar e tornou esse ato bastante monótono, já que eu, muitas vezes, não podia escolher o que desenhar ou mal tinha tempo de realmente me dedicar ao desenho. O estúdio me fez voltar a ver o desenho como forma de me expressar e como uma diversão, podendo soltar a minha criatividade sem a pressão que a faculdade traz, e por ser algo semanal, eu também consegui construir um hábito de desenho que eu não tinha. Foi extremamente importante pro meu desenvolvimento de traço e pra manter o gosto pelo desenho vivo em mim hahaha."

Depoimento da estudante L.R., do segundo período de Design, ESPM Porto Alegre

3

"Eu achei muito importante!! Mesmo eu infelizmente quase não conseguindo participar, já faz uma diferença enorme quando eu participei!! Foi um ótimo incentivo pra continuar treinando desenho e testar coisas novas sempre!!."

Depoimento da estudante C.A., do segundo período de Design, ESPM Rio

4

“É muito bom ter um espaço criativo pra gente trocar técnicas e experiências novas ! Eu sempre me sinto muito tranquila no Estúdio pq eu não tenho a pressão de receber uma nota, eu desenho pq eu estou com vontade. E poder desenhar junto 
de pessoas que eu gosto deixa tudo mais divertido, principalmente quando a gente inventa um tema doido pra desenhar hehe."

Depoimento da estudante M.E.C., do quarto período de Design, ESPM Rio

\section{Alguns números}

Para termos uma ideia melhor do volume de trabalho e participação dos estudantes no Estúdio de Desenho no Exílio ao longo do ano de 2020, durante a reclusão imposta pela pandemia do Covid-19:

- Encontros online gravados: 18

- Grupo de Whatsapp com 74 membros.

- Participantes que criaram pastas e compartilharam trabalho: 46

- Maior número de desenhos compartilhado por um estudante: 58

- Total de desenhos compartilhados: 641

- Postagens no Instagram: 209

\section{6}

\section{Reflexão na ação}

Nos dois modelos de funcionamento do Estúdio de Desenho ocorreu o aprendizado significativo, sobretudo pelo caráter colaborativo que viabilizou a aprendizagem por pares.

A maior parte dos participantes sempre foi de estudantes de Design, porém houve estudantes de outros cursos de graduação da ESPM e em alguns casos estudantes de outras instituições que eram amigos dos estudantes da ESPM.

Enquanto o experimento da Cidade Submarina estava direcionado ao desenvolvimento da criatividade pela ruptura dos padrões de percepção, utilizando o raciocínio divergente e o estranhamento, como algo diretamente útil ao processo criativo de estudantes de Design, cabe dizer que o Estúdio de Desenho parece ser somente uma atividade artística sem utilidade aparente. Segundo Ionesco (1965, p.140, apud Ordine, 2013, p.18), "se não se compreende a utilidade do inútil e a inutilidade do útil, não se compreende a arte"

Segundo Schön (2000, p. 20), a pesquisa acadêmica não precisa render somente conhecimentos profissionais úteis, aplicáveis a demandas práticas imediatas. Apesar de no Estúdio todos desenvolverem suas habilidades de desenho, e isso é claramente útil a eles profissionalmente, a pesquisa aqui se relaciona à compreensão de como esse aprendizado aconteceu.

Não houve aulas de desenho no Estúdio de Desenho, nenhuma aula formal aconteceu, porém sinto que todos que participaram desenvolveram seu desenho de um modo muito pessoal, de uma forma que talvez fosse impossível em aulas tra- 
dicionais. Nas aulas tradicionais, por mais que sejam propostos exercícios abertos, sem necessariamente prever resultados similares, há um caminho dado pelo professor, um direcionamento, e todos caminham na mesma direção.

O modelo de Estúdio Livre, funcionando como um ateliê de prática artística, permitiu que cada um escolhesse uma direção de desenvolvimento. E permitiu àqueles que não tinham uma direção que embarcassem descomprometidamente em um exercício lúdico, divertido e interessante, e aprendessem também.

Como nos grupos operativos, todos os temas de trabalho, direcionamentos e mobilizações vieram do grupo, sobretudo quando estávamos presencialmente reunidos. $\mathrm{O}$ grupo se manteve e se renovou segundo dinâmicas internas próprias e estava crescendo em organização e mobilização enquanto grupo com a organização do espaço, da divulgação do Estúdio e com a criação da feira de impressos.

Quando mudamos de ambiente, tendo sido obrigatoriamente movidos para o meio digital, o grupo se transformou e passou por uma renovação quase completa, tendo sido necessário intervir remodelando a dinâmica.

No funcionamento remoto conseguimos manter a troca, o aprendizado por pares, ainda que afastados fisicamente. Criou-se um ar de "clube", de que todos faziam parte, em que podiam intervir e planejar, porém não percebi o mesmo engajamento de "time" que havia, pois de fato os participantes não se conheciam antes. O segundo semestre no modelo online já trouxe essa familiaridade remota entre os estudantes.

Olhando para a forma que esse aprendizado aconteceu no Estúdio de Desenho, percebo que está inteiramente relacionada ao "aprender a aprender", que é objetivo central de todas as Metodologias Ativas. Não pude acompanhar de perto os estudantes egressos do Estúdio de Desenho, mas pude testemunhar no quarto período uma melhoria geral no nível de desenvolvimento dos projetos integrados de exposições, comparando as turmas anteriores e posteriores ao surgimento do Estúdio de Desenho, então posso arriscar-me a inferir que contribuimos qualitativamente nesse processo. Tal percepção tem sido confirmada por outros professores.

Segundo Dewey (1974, p.151, apud Schön, 2000, p. 25), não devemos ensinar ao estudante o que ele precisa saber, mas precisamos instruí-lo a enxergar por conta própria as relações entre os meios, métodos e resultados. Ninguém pode ver pelo estudante, mas podemos guiar seu olhar para ajudá-lo a ver.

Quando estamos habituados a fazer algo (no caso, a desenhar), segundo Schön (2000) temos um "conhecer-na-ação" que nos leva a realizar as coisas de forma quase automática.

Quando somos desafiados ou nos propomos fazer algo um pouco fora do comum, vivemos uma experiência que dá margem a erros. Tais erros podem ser, no desenho, erros mesmo ou simplesmente uma frustração de expectativas (o realizado se distancia do imaginado) ou mesmo o desconforto da experimentação de mate- 
riais diferentes. Quaisquer resultados obtidos, bons ou ruins, nos permitem refletir sobre o desenho retrospectivamente e analisar o que fizemos.

As dinâmicas do Estúdio de Desenho permitiram uma reflexão durante o processo, pela repetição de exercícios, compartilhamento e debate, que Schön (2000, p. 32) denomina “reflexão na ação". A reflexão na ação permite intervir no presente, modificando os processos enquanto acontecem, em que a reflexão sobre cada tentativa e seus resultados modifica as tentativas seguintes.

\footnotetext{
"A reflexão gera o experimento imediato. Pensamos um pouco e experimentamos novas ações com o objetivo de explorar os fenômenos recém observados, testar nossas compreensões experimentais acerca deles, ou afirmar as ações que tenhamos inventado para mudar as coisas para melhor." SCHÖN $(2000$, p. 34)
}

Percebi que nas edições online, nos dois semestres de 2020, a partir da dinâmica de desenhar e mostrar o Aprendizado por Pares, se deu em paralelo a essa reflexão na ação, tendo sido por ela conduzido de forma diferente do Estúdio presencial.

No Estúdio presencial havia desenhos mais longos e elaborados, os participantes ficavam investigando temas ou materiais, aquarela por exemplo. Em um encontro do estúdio agrupavam-se alguns estudando aquarela e desenvolviam desenhos nessa técnica, aprendendo por observação, pela experiência ou mesmo ensinando uns aos outros. A reflexão na ação acontecia enquanto aquele desenho ia sendo preparado. Em paralelo podia haver um outro grupo estudando o desenho de rostos, em processo similar de trocas. Pela profundidade do aprendizado, a evolução continuava no desenho seguinte e o progresso se manifestava nos projetos pessoais, deixando o que os estudantes traziam ao longo das semanas muito interligado.

No estúdio online havia geralmente uma proposta comum a todos durante os encontros, como desenhar expressões faciais. Projetávamos videos ou imagens de modelos por um tempo pré-determinado e quase todos desenhavam a mesma coisa, de forma rápida, como sketches (alguns ficavam conectados conversando mas desenvolvendo seus projetos pessoais). De tempos em tempos compartilhávamos os desenhos e comentávamos o que tinhamos achado bom, e em que tinhamos encontrado dificuldade. Pela observação de como o outro havia resolvido algum problema, ou pelas dicas recebidas, dava-se a reflexão na ação e na sequência seguinte já fazíamos desenhos aprimorados. Pela velocidade dos sketches e da reflexão, a evolução era rápida e se dava de forma cruzada, como num improviso de jazz em que cada músico vai improvisando a partir do que o outro acabou de tocar.

Resta somente dizer que no modelo presencial a técnica teve um desenvolvimento maior que a forma e no modelo online a forma se desenvolveu mais que a técnica. Em ambos, segundo a Teoria de Grupos Operativos de Pichón-Rivére (1986), por termos conseguido um ambiente de liberdade, o foco esteve no desenvolvimento (qualidade) e nem tanto na conclusão de tarefas. 


\section{5 Proposição de outras práticas pedagógicas a partir da aprendizagem significativa em Design.}

Ao longo da pesquisa de campo, à medida que observava o que estava acontecendo, fiz uma pesquisa bibliográfica que me permitiu compreender o desenrolar das atividades experimentadas. A partir dessas percepções, pude replanejar os experimentos de campo como se espera de uma pesquisa-intervenção, mas em paralelo tive ideias novas que combinavam aspectos da Cidade Submarina e do Estúdio de Desenho, ou eram desdobramentos desses.

Compartilho aqui essas proposições, sem tê-las experimentado, como possíveis desdobramentos e caminhos de retomada da pesquisa desta tese. Uma vez que não foram testadas, seu resultado é ainda desconhecido e não são apresentadas quaisquer análises, depoimentos ou hipóteses a partir delas.

\section{1 \\ Chaveiro de significação de atividades}

Das quatro proposições apresentadas esta é a única relacionada ao planejamento de disciplinas, podendo ser experimentada em qualquer disciplina de Design ou de qualquer outra área do conhecimento em que se busque o aprendizado significativo dos estudantes.

Quando pensamos em algo realmente importante que tenhamos aprendido, um marco em nossas vidas, não necessariamente um aprendizado acadêmico, tendemos a recordar algo talvez recente, de impacto ainda fresco. À medida que refletimos, vamos regredindo no tempo, mergulhando na lembrança de descobertas cada vez mais antigas e fundamentais. Percebemos que esses marcos foram pontos de partida e determinantes para o que aprendemos em seguida.

Cada turma é composta por estudantes que trazem diferentes marcos de aprendizagem e interesses variados e é preciso criar situações de ensino-aprendizagem que favoreçam o encontro do que cada um já possui com novos materiais e informações, contribuindo para trazer à tona motivações que os levem a ter um papel ativo no processo de aprendizagem. Se os estudantes não estiverem dispostos a assumir esse papel, as Metodologias Ativas não surtirão o efeito desejado. 
Uma questão essencial à boa aplicação das Metodologias Ativas, portanto, é fazer estudantes diferentes encontrarem significado no que aprendem, fazê-los entrar em ação, criar estratégias que permitam torná-los mais ativos para que possam aproveitar plenamente o processo de aprendizagem e atingir os objetivos educacionais delineados.

O projeto de um curso superior é feito estrategicamente a partir das competências, habilidades e atitudes que alunos egressos deverão demonstrar. O planejamento dos objetivos de aprendizagem de cada disciplina leva em conta as conexões com as demais disciplinas, sobretudo com aquelas que o estudante está cursando no mesmo período letivo. A definição desses objetivos educacionais frequentemente segue uma lógica de aprendizagem hierarquizada a partir da Taxonomia de Bloom (Krathwohl, 2002), onde o estudante primeiro deve recordar o que sabe, compreender, ser capaz de aplicar, de analisar o resultado, de avaliar e finalmente criar.

A Taxonomia da Aprendizagem Significativa de Fink (2007) descreve seis diferentes categorias de aprendizagem que podem trazer significado para os estudantes, sensibilizando-os para que iniciem um processo de aprendizagem significativa. O "Chaveiro de Significação de Atividades" é uma aplicação pensada a partir do instrumento de análise desenvolvido nessa pesquisa, e apresentado no capítulo 2 , sugerindo um modo de combinar diferentes Metodologias Ativas a partir das categorias de aprendizagem significativa, para potencializá-las.

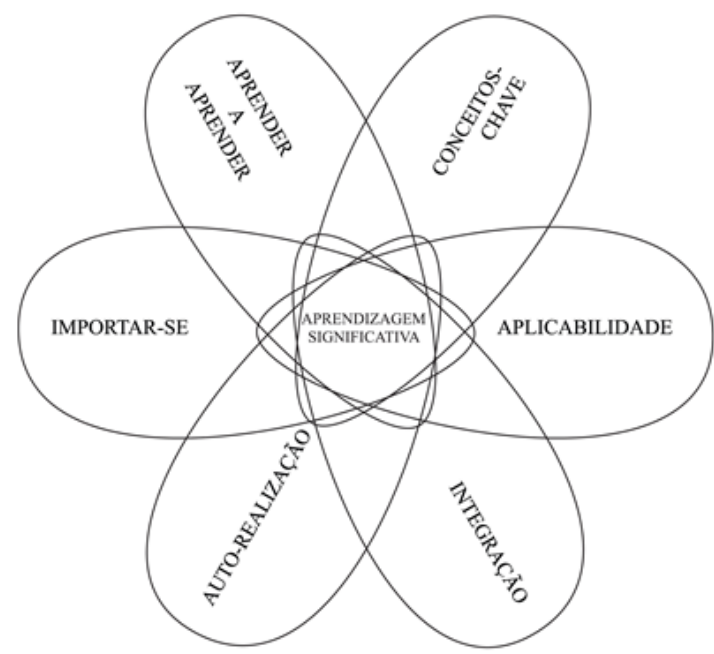

Figura 5.1 - Taxonomia da Aprendizagem Significativa Fonte: Fink (2007) / adaptação do autor.

Segundo FINK (2007), a aprendizagem significativa está na interseção de seis categorias de aprendizagem:

- Conceitos-chave (foundational knowledge) - A base para os outros tipos de aprendizagem em uma disciplina é seu conteúdo essencial, seus conceitos-chave. Saber algo está relacionado à capacidade de o estudante entender e lembrar de informações e ideias específicas da disciplina. 
- Aplicabilidade (application) - aprendizagem relacionada à aplicação intelectual, física ou social do que é estudado, muitas vezes envolvendo o desenvolvimento de novas habilidades ou competências. A aplicabilidade traz um ar de utilidade ao que é aprendido.

- Integração (integration) - quando os estudantes percebem que diferentes conhecimentos, pessoas, ideias estão conectados, aprendem algo novo que surge da conexão percebida.

- Auto-realização (human dimension) - Quando os estudantes descobrem algo sobre si, implicações pessoais do que aprenderam, adquirem uma nova percepção de quem são e do que podem atingir. Essa categoria de aprendizagem relaciona-se também à melhor compreensão de como os outros agem e da interação do estudante com seus pares.

- Importar-se (caring) - quando o aprendizado influi na forma que o estudante vê as coisas, altera seus valores, muda seus pontos de vista. $\mathrm{O}$ aprendizado relacionado a esta categoria traz grande engajamento.

- Aprender a aprender (learning how to learn) - quando, no processo de aprendizagem, os estudantes descobrem algo sobre como aprendem melhor, sobre como podem se tornar melhores estudantes e que são capazes de aprender por conta própria.

A partir da Taxonomia de Fink (2007) realizei diversos experimentos acadêmicos que foram a base de minhas pesquisas de mestrado e doutorado. Percebi que poderia sistematizar sua aplicação em dois momentos: na definição das atividades de ensino-aprendizagem, para melhor atingir os objetivos das disciplinas, e na verificação dos resultados obtidos, possibilitando a reflexão na ação e o aperfeiçoamento de todo o processo.

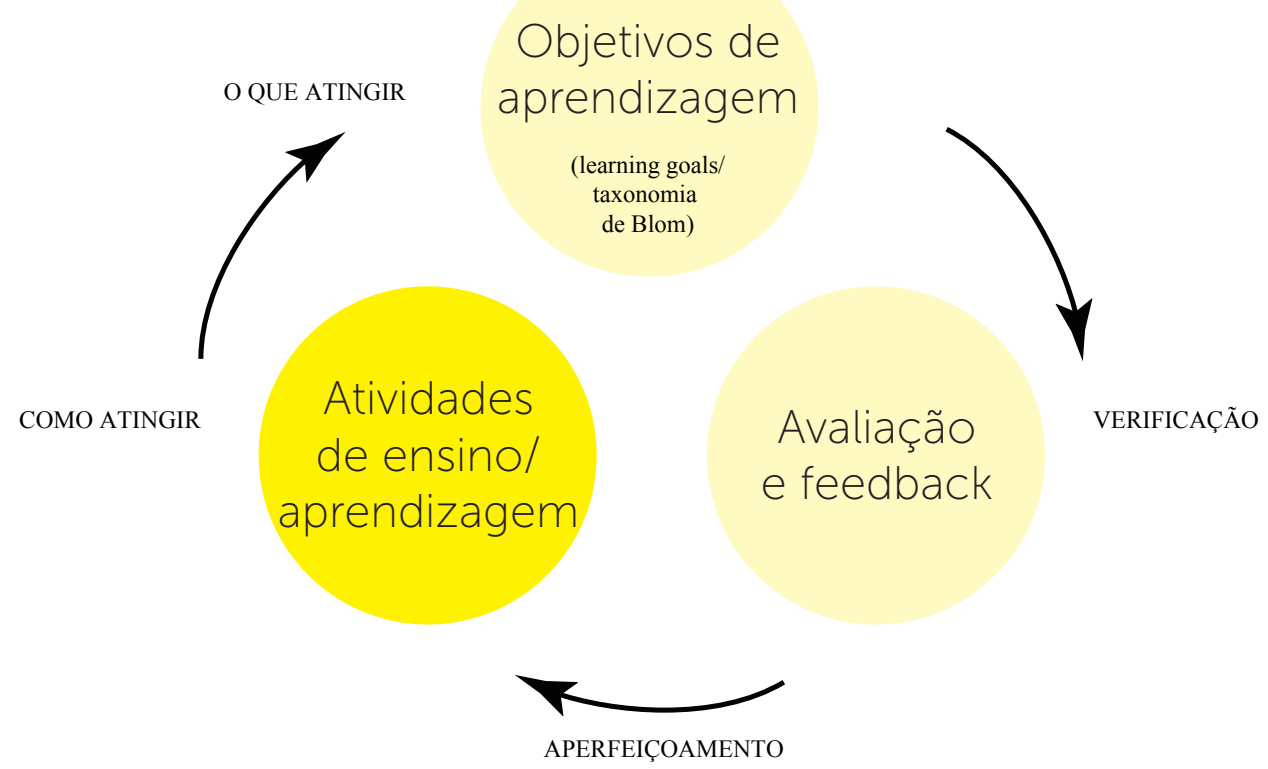

Figura 5.2 - Etapas do processo de ensino-aprendizagem

Fonte: ilustração do autor. 
Considerando que cada estudante pode ser sensibilizado por diferentes estímulos, e partindo do pressuposto que tais estímulos estariam contemplados pelas categorias de aprendizagem significativa de Fink (2007), podemos inferir que, sempre que em uma disciplina for possível criar atividades que favoreçam as seis categorias de aprendizagem significativa, todos os estudantes terão sido afetados e ativados em algum ponto.

Enquanto estudava e experimentava a aplicação de metodologias ativas, percebi que, à luz de Fink (2007), era possível identificar quais categorias de aprendizagem eram mais relevantes em cada uma.

Se pensarmos em cada categoria de aprendizagem significativa como uma chave de ativação da aprendizagem, é possível, a partir dos objetivos de aprendizagem, criar para cada um deles atividades que atinjam diferentes categorias de Fink. A combinação de diferentes atividades, pensadas a partir de diferentes chaves de ativação da aprendizagem, constitui um chaveiro de significação da disciplina. Com o chaveiro de significação para as atividades, potencializamos a chance de criar significados, ativando o processo e engajando o estudante.

Como qualquer projeto, o planejamento de uma disciplina não está somente ligado aos objetivos, mas lida com hipóteses quanto ao que será obtido e resultados alcançados. A distância entre o que se deseja alcançar e o que de fato foi atingido é subjetiva, porém quando pode ser percebida, permite refletir sobre o que poderia ser aprimorado, gerando correções de rumo para a condução das turmas seguintes.

As verificações de aprendizagem são em sua maioria quantitativas: provas, trabalhos e tarefas levam às notas. Muitos estudantes, nos modelos tradicionais de ensino, orientam sua passagem pela academia segundo a obtenção de notas e não pelo real aprendizado das disciplinas.

A aprendizagem significativa deve ser avaliada qualitativamente e aqui reside o ganho que pode ser obtido a partir da subjetividade do processo. A partir das seis categorias de aprendizagem significativa, imaginei que aos estudantes seria possível dizer qual ou quais categorias os impactaram em maior ou menor grau. Pesquisei e desenvolvi um instumento de análise e planejamento a partir da Taxonomia de Fink (2007) que permite mapear a expectativa do professor, as expectativas de sua turma e a percepção dos estudantes quanto aos ganhos obtidos ao longo do semestre. A partir dessas percepções é possível identificar pontos em que o planejamento de atividades e aulas pode ser aperfeiçoado.

$\mathrm{Na}$ pesquisa de mestrado eu havia identificado e classificado algumas práticas pedagógicas minhas e de alguns professores ${ }^{1}$, e a partir da pesquisa do instrumento de avaliação e análise que desenvolvi a partir de Fink (2007) pude sintetizar o chaveiro de atividades, nomeando-o Chaveiro de Significação de Atividades.

1 Beltrão (2017) p.78-81 


\section{Planejando aulas ativas com o Chaveiro Significação de Atividades}

Seguindo a analogia em que cada categoria da taxonomia de Fink (2007) pode ser vista como uma chave para a ativação e engajamento dos estudantes, e considerando que em uma turma há estudantes que poderiam ser ativados por diferentes meios, conclui-se que quanto mais categorias de aprendizagem significativa forem atingidas, mais chaves de ativação serão utilizadas e será possível sensibilizar um número maior de estudantes.

A partir dos objetivos de aprendizagem definidos no planejamento das disciplinas, é possível criar um conjunto de atividades que atinjam diferentes categorias de Fink (2007), combinando-as nas disciplinas. Desse modo, potencializamos a chance de criar significados, ativando o processo de aprendizagem e engajando em algum ponto os estudantes.

atividade 1

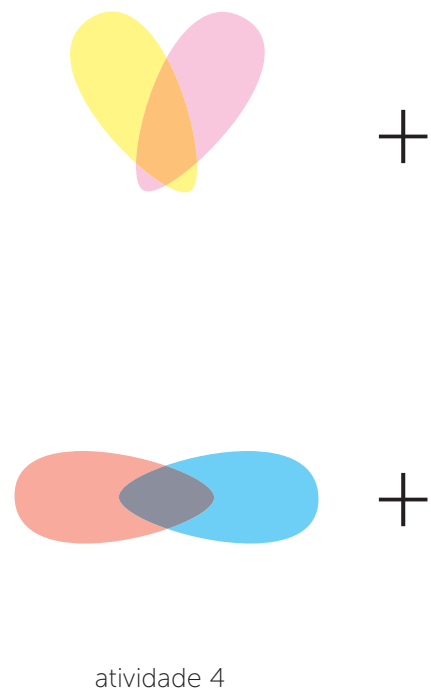

atividade 2
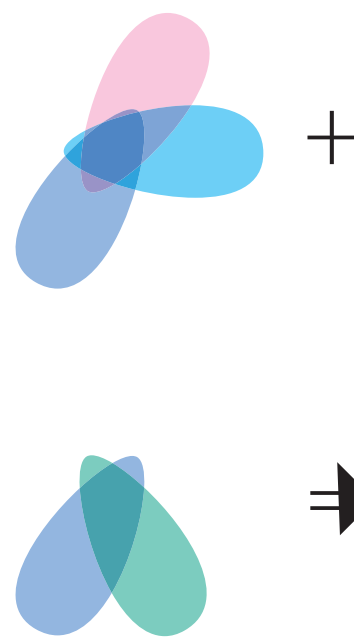

atividade 5 atividade 3
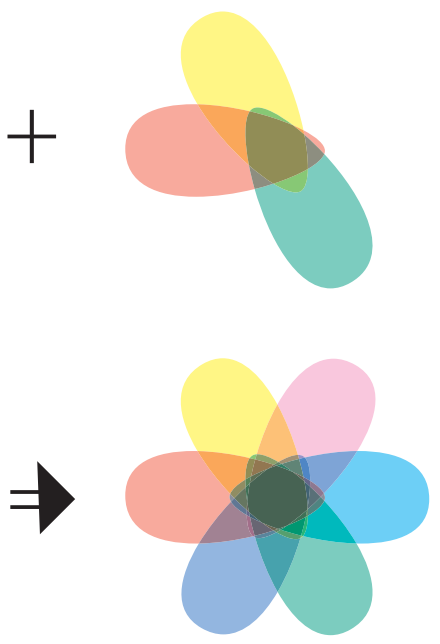

Figura 5.3 - Chaveiro significação de atividades. Fonte: ilustração do autor

O planejamento de aulas utilizando diferentes chaves pode representar uma combinação de Metodologias Ativas, ou a aplicação de uma metodologia-base, aditivada por práticas pedagógicas complementares.

Cada chave pode ser escolhida pontualmente como solução para pontos críticos das disciplinas.

Em uma disciplina de caráter prático, por exemplo, em que determinado conteúdo teórico sempre tenha sido recebido com desinteresse pelos estudantes, poderíamos utilizar uma chave de aplicabilidade combinada a outra de auto-realização. Em outras palavras, o conteúdo teórico poderia ser transmitido com apoio de alguma prática desafiadora que demonstrasse sua aplicação, e resolvi testar essa configuração.

O experimento foi realizado dentro do exercício projetual da Cidade Submarina (capítulo 3), com excelentes resultados. Os estudantes, em certo ponto, preci- 
savam realizar entrevistas nessa disciplina. Na configuração tradicional, havia uma aula sobre técnicas de entrevista apoiada por bibliografia, seguida do planejamento das entrevistas que precisariam realizar. Nesse modelo tradicional, os estudantes acabavam demonstrando que não tinham de fato aprendido a fazer entrevistas e os resultados eram sempre muito fracos.

A recepção dos alunos à configuração tradicional dessa aula, modelo tradicional teórico, era sempre de desinteresse e apatia. Na configuração projetada a partir do chaveiro, criamos um pequeno texto polêmico envolvendo alguns personagens fictícios que foram representados por professores. Após lerem o texto, os alunos dividiram-se em grupos e entrevistaram os personagens, que responderam de forma improvisada às questões também improvisadas, e realizamos um debate acerca das opiniões dos alunos quanto ao que fora obtido nas entrevistas.

Após animado debate, concluíram que tinham registrado muitas informações conflitantes, que tinham esquecido de perguntar questões importantes, e que de algum modo tinham influenciado algumas respostas. A partir desse ponto, foi possível a aula teórica sobre técnicas de entrevista, com grande adesão e participação dos estudantes. Eles aprenderam as técnicas de entrevista (conceitos-chave), vivenciaram na prática os problemas surgidos por não terem planejado a entrevista (aplicabilidade) e na etapa seguinte conseguiram fazer ótimas entrevista em seus projetos a partir do que tinham aprendido (auto-realização).

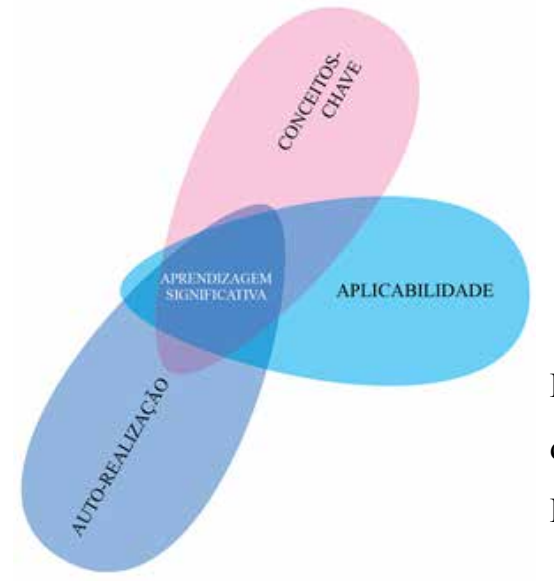

Figura 5.4 - Representação visual da atividade prática de entrevistas Fonte: ilustração do autor

Segundo o mesmo critério de representação visual, poderíamos dizer que a Metodologia Ativa conhecida como Estudo de Casos Modelo Harvard está relacionada diretamente a aplicablidade e a integração.

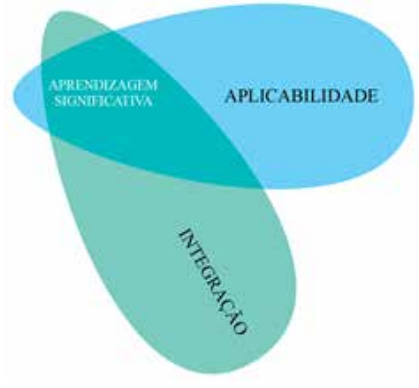

Figura 5.5 - Representação visual do Estudo de Casos Modelo Harvard. Fonte: ilustração do autor a partir de sugestão do prof. Gaspar Giacomini 
Podemos mesclar metodologias ativas ou criar exercícios que favoreçam ao longo do semestre um "chaveiro" mais diversificado que a aplicação de uma única metodologia ativa ao longo do semestre inteiro. Nos exemplos acima, se uma atividade de estudo de caso tivesse sido realizada logo após a prática de entrevistas, teriam sido atingidas quatro das seis categorias da aprendizagem significativa de Fink (2007).

\section{2}

\section{Disciplina eletiva de representação bidimensional}

A partir da observação da aprendizagem colaborativa que pude fazer durante o experimento da Cidade Submarina, enquanto acontecia ainda o início do Estúdio de Desenho, propus uma disciplina eletiva na PUC-Rio que unisse o espírito livre do Estudio de Desenho, criando uma atmosfera de atelier, a um processo colaborativo avaliado de construção de projetos pessoais de Design.

Infelizmente, devido à crise econômica que progressivamente afetou o volume de matrículas de todas as instituições privadas, não conseguimos abrir essa nova disciplina e ela não pôde ser testada.

Alguns elementos da proposta, porém, foram incorporados ao próprio Estúdio de Desenho e a uma disciplina de Criatividade que passei a lecionar na ESPM.

Proposta de disciplina para 2019.2 / Professores Rita Couto e André Beltrão Tema: Estúdio Livre de Representação, 2 créditos - 30 horas $^{2}$

\section{Ementa}

Aprendizagem ativa de temas relacionados à representação bidimensional. Formação de grupos inspirados em grupos operativos. Metodologia participativa para o desenvolvimento de investigações pessoais dos estudantes.

\section{Objetivos}

- Incentivar o aluno a desenvolver investigações de linguagens/expressões de representação bidimensional, a partir de interesses pessoais, que sejam relevantes para sua formação.

- Incentivar o desenvolvimento da aprendizagem significativa a partir do aprofundamento de temas de interesse dos alunos.

- Incentivar aprendizado pelos pares através de trocas de informações, habilidades e competências.

- Desenvolver habilidades de representação.

2 O plano de aulas da eletiva está nos apêndices. 


\section{Metodologia}

Pensado como um estúdio livre de representação, será guiado por uma metodologia de cunho exploratório.

As aulas serão conduzidas de forma a incentivar que os alunos escolham temas, técnicas, materiais, estilos etc. de seu interesse para desenvolver investigações pessoais a partir de um contexto inicial comum de universo ficcional.

A dinâmica das aulas incluirá desenvolvimento participativo com trocas entre os alunos e trabalhos em grupo com funcionamento inspirado nas teorias de grupos operativos.

\section{Programa}

- O trabalho autoral: desenvolvimento de propostas pessoais de investigação da representação bidimensional a partir de um tema ficcional; dimensão expressiva.

- A representação bidimensional: estilos e referências de representação bidimensional.

- O trabalho em grupos operativos: desenvolvimento participativo de problematização, geração de ideias e discussões conceituais, criação participativa.

\section{Sistema de avaliação}

G1

Avaliação inicial de expectativas a partir da Taxonomia da Aprendizagem Significativa (FINK, L. D., 2007)

Itens qualitativos a serem avaliados: participação e qualidade do trabalho em grupo. Itens quantitativos a serem avaliados: frequência

G2

Auto-avaliação de desempenho a partir da Taxonomia da Aprendizagem Significativa (FINK, L. D., 2007)

Itens qualitativos a serem avaliados: participação, qualidade do trabalho em grupo e portfolio de desenvolvimento pessoal.

Itens quantitativos a serem avaliados: frequência

\section{3 \\ Experimento colaborativo internacional Cidade Submarina 3.0: Introdução, objetivos, planejamento}

Elaborei no ínicio de 2019 um experimento colaborativo internacional a partir do que havia experimentado com a Cidade Submarina e com o Estúdio de Desenho.

Introduzi aqui um novo elemento, a distância, que deveria ser suprida através de algum ambiente virtual em que os estudantes pudessem compartilhar suas pes- 
quisas, observações e resultados. Ele aconteceria no segundo semestre de 2019 e foi uma pena que não o tenhamos realizado, pois teria sido muito inovador e relevante, tendo em vista o isolamento a que todos fomos submetidos no ano seguinte, com a pandemia do Covid-19. O experimento não aconteceu por opção, pois na qualificação desta pesquisa optamos por interromper o campo e direcionar o foco à análise do que tinha já sido obtido.

Para essa elaboração busquei inspiração na Metodologia Ativa Challenge Based Learning ${ }^{3}$, que é uma variação do aprendizado por problemas totalmente baseada em ambientes colaborativos digitais, unindo-a ao Ensino sob Medida e ao Aprendizado por Pares, Metodologias Ativas que já haviam sido exploradas na Cidade Submarina original.

Para que o exercício pudesse ser compartilhado com alunos de outra escola, pensei desde o início em buscar alguma que estivesse distante daqui, imaginando que seria uma oportunidade de avaliar a influência de algum fator cultural no projeto. Fui apresentado a uma professora da Interamerican University, em Porto Rico, e chegamos a combinar a experimentação da atividade..

Como Porto Rico fica exatamente em uma das extremidades do Triângulo das Bermudas, propus reescrever nosso contexto-ficção situando a Cidade naquela região, sendo o laboratório mais antigo, tendo sido fundado logo após a primeira guerra mundial. Logo de cara imaginei que todos os naufrágios e desaparecimentos de aeronaves seriam na verdade imigrantes mudando-se secretamente para a Cidade.

Devido à diferença de línguas, ao invés de uma entrevista ao vivo imaginei um conjunto de videos previamente gravados com depoimentos dos gerentes da Cidade. No início do exercício as perguntas seriam feitas em um fórum online, e ao longo da aplicação do exercício, tal fórum continuaria ativo, sendo respondido diariamente pelo ancião. As reuniões seriam ora virtuais, com os professores e estudantes dos dois países, ora presenciais, reuniões locais de desenvolvimento.

\section{SOBRE O EXERCÍCIO}

O exercício projetual colaborativo Cidade Submarina 3.0 foi pensado como um exercício projetual com duração de 3 semanas, realizado à distância, contando com espaço colaborativo virtual para compartilhamento de pesquisas e apresentações. Envolveria a participação de estudantes de duas instituições de ensino (ESPM e uma segunda instituição localizada em Porto Rico), com a participação de cerca de 15 estudantes e um professor em cada instituição, no qual o pesquisador será observador participante. 


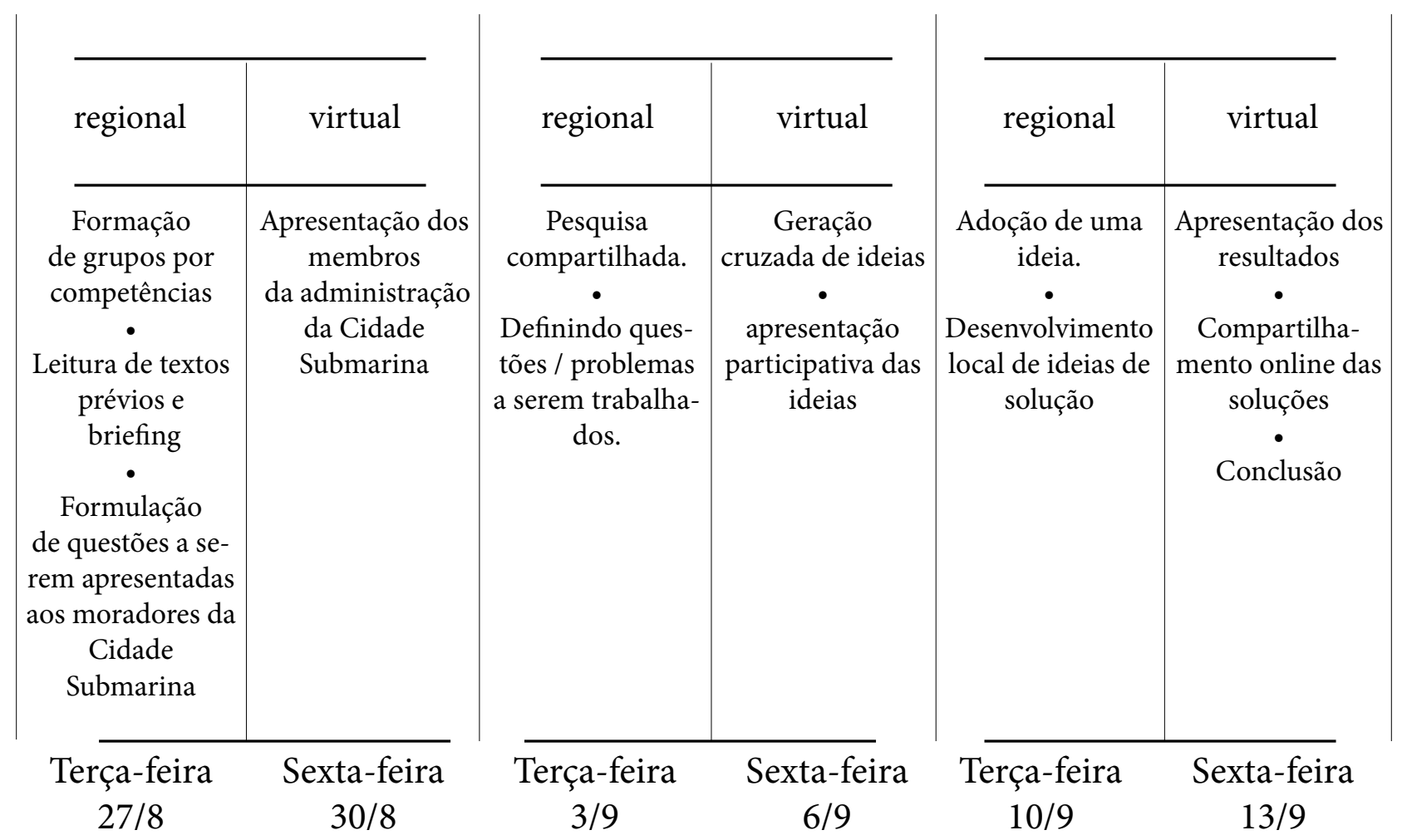

\section{OBJETIVOS ESPECÍFICOS DA ATIVIDADE:}

- Quebrar bloqueios criativos dos alunos pela quebra de paradigmas.

- Motivar a criatividade e o engajamento pela disrupção dos padrões.

- Avaliar o quanto diferenças culturais de estudantes das duas intituições podem ser percebidas nos resultados atingidos.

- Criar ambiente colaborativo de autoaprendizagem.

Registro: o professor de cada instituição deve fazer o registro fotográfico do processo e dos resultados e compartilhar no espaço colaborativo virtual.

\section{METODOLOGIA DO EXERCÍCIO}

O exercício se baseia no deslocamento dos referenciais para um universo de ficção, uma heterotopia (Foucault), em que a presença de elementos familiares aos participantes adquire novos significados por estarem inseridos em contextos diferentes.

Tal deslocamento é acentuado pelo processo, pois os estudantes entrevistam moradores da Cidade Submarina e precisam fazer uma pequena imersão no universo do local para encontrarem problemas de projeto que possam estudar.

$\mathrm{O}$ deslocamento de referenciais favorece a geração de ideias novas.

$\mathrm{O}$ ambiente colaborativo permite o compartilhamento de pesquisas e a criação compartilhada de soluções.

Foram propostos três encontros virtuais e três encontros regionais de desenvolvimento. 


\subsection{Disciplina eletiva colaborativa Estúdio Livre de Desenho / em modelo misto (presencial e online)}

Apesar de ter optado por não realizar outros experimentos pedagógicos por ocasião da minha qualificação, o isolamento social decorrente da pandemia do Covid-19 deslocou-nos todos para o ambiente virtual.

Sem que houvesse planejado propositalmente, precisei reconduzir o Estúdio Livre de Desenho a esse novo modelo, como relatado no capítulo 4, e creio que consegui fazê-lo com bastante sucesso porque tinha pensado um pouco e pesquisado algumas possibilidades de interação quando estava formulando a Cidade Submarina internacional, que acabou não sendo testada.

A partir da experiência bem sucedida do Estúdio de Desenho no Exílio, a aplicação online, propus à ESPM uma disciplina eletiva parte presencial e parte online, unindo simultaneamente estudantes e professores das três unidades da escola (Rio, São Paulo e Porto Alegre).

Alguns encontros se realizariam virtualmente, como temos feito no Estúdio de Desenho no Exílio, e outros aconteceriam presencialmente, resgatando o modelo anterior do Estúdio Livre. Esse modelo misto teria, durante os encontros presenciais, a interligação por vídeo com os estúdios presenciais das outras unidades.

Cada professor em sua unidade poderia conduzir os presenciais, acompanhando o desenvolvimento dos projetos pessoais. As salas poderiam estar interligadas por câmeras, via zoom, e enquanto o pessoal vai produzindo, eventualmente ao longo desses presenciais poderia também ir vendo o que acontece nas outras salas.

Nomeei essa disciplina Estúdio livre de Desenho e Expressão Visual, abrindo assim o leque de possibilidades (colagem, pintura, gravura, serigrafia, etc).

Com relação ao modelo misto, pensei no seguinte funcionamento $(\mathrm{P}=$ presencial $/ \mathrm{W}=$ webconferência):

Primeiro mês de sensibilização e exploração, conversa, reflexão onde iniciariam processos investigativos pessoais. Encontro presencial inicial intercalado com webconferências. (P/W/P/W)

Os dois meses seguintes seriam de desenvolvimento dos projetos pessoais. Ao longo desse tempo haveria encontros presenciais e webconferências intercaladas. Nos presenciais faríamos acompanhamentos individuais e nas webconferências faríamos exercícios de desenho propostos pelos estudantes, como tem sido no Estúdio Livre, para desenvolvimento e experimentação de todos. (P/W/P/W/P/W/P/W)

No último mês faríamos dois encontros presenciais seguidos (acompanhamento dos projetos) e depois duas webconferências seguidas (apresentação de todos os projetos das 3 unidades). (P/P/W/W). 
A proposta dessa eletiva foi pré-aprovada e está por enquanto aguardando os desdobramentos dessa reclusão imposta pela pandemia, pois, ao contrário do que se esperava, ou desejava, continuaremos todos em regime de aulas à distância em 2021. Em função disso, não posso expor aqui o plano de ensino-aprendizagem que foi elaborado.

Três das quatro proposições, ainda que não tenham sido implementadas ou testadas, já geraram subprodutos. O chaveiro de atividades foi transformado em um treinamento para professores da $\mathrm{ESPM}^{4}$, a eletiva de representação bidimensional teve parte de seu planejamento incluído em uma disciplina de Criatividade que leciono na ESPM, assim como a estrutura de trabalho colaborativo online do Challenge Based Learning, que seria utilizada na Cidade Submarina 3.0.

Todas as proposições foram estruturadas a ponto de poderem ser iniciadas imediatamente, não o foram pela necessidade de foco desta pesquisa. Algumas outras ideias ainda mais abertas surgiram como possíveis continuações para esta investigação e serão apresentadas a seguir. 


\section{6 Considerações finais}

A pesquisa de doutorado é longa e os longos anos que dura testemunham muitas mudanças na vida do pesquisador, de tal forma que a pesquisa e a vida se fundem e os temas pesquisados se tornam caminhos abertos para o resto da vida e a vida se torna um grande campo de pesquisa.

Esse percurso começou para mim na pesquisa de mestrado e seguiu imediatamente por caminhos que dali apontaram: fechei meu escritório e passei a dedicar toda minha vida profissional ao ensino, que era meu tema e campo. Ao longo das minhas investigações, tudo teimava mudar a cada semestre - novas ideias, novos obstáculos, novos caminhos, mas era preciso manter o foco, a síntese, a prática projetada.

Ficaram ao longo do caminho muitos possíveis pontos de partida para novas pesquisas, algumas ideias já para pós-doutorado, para outras investigações.

Algumas dessas ideias tornaram-se proposições de práticas pedagógicas, que não pude experimentar por diferentes motivos, o principal deles o tempo, que obrigava ao foco. Apresentei quatro dessas proposições pedagógicas no capítulo 5.

Outras ideias poderão gerar desdobramentos e retomadas da pesquisa, algo que de certo modo já se inicia em paralelo ao final do doutorado.

\section{Conectando o campo à questão norteadora e à hipótese}

A pesquisa de mestrado que desenvolvi imediatamente antes desta tese terminou com duas sugestões de continuação:

1 - Estudos relacionados às motivações, pois segundo Dewey (1980) não é possível criá-las, mas talvez seja possível prospectar ou identificar as motivações.

2 - Uma pesquisa sobre formas de "ativar" a criatividade em disciplinas de Design Gráfico.

$\mathrm{Na}$ referida pesquisa, estudei longamente as Metodologias Ativas de ensino-aprendizagem e os ativismos pedagógicos que conduziram a elas, sobretudo o conceito de aprendizagem significativa de Ausubel (1963), desenvolvido posteriormente na Taxonomia da Aprendizagem Significativa de Fink (2007).

Ao longo do doutorado, parti da aplicação prática de Fink (2007), elaborando um instrumento de análise e avaliação de disciplinas, que posteriormente se revelou 
útil como instumento de planejamento de aulas. Fiz, a partir disso, a proposição de um "chaveiro de significação de atividades", apresentado no capítulo 5.

O desenvolvimento desse instrumento foi relevante para que eu pudesse compreender melhor o engajamento dos estudantes no processo de aprendizagem significativa e, assim, para que fosse possível vislumbrar o que os motivava positivamente a se engajarem no processo de ensino-aprendizagem. Formulei uma questão norteadora para a tese a partir desse ponto ${ }^{1}$.

Quis investigar em campo o quanto poderia promover o aprendizado significativo de forma consciente pelo planejamento de aulas e exercícios projetuais. Tal planejamento de atividades foi meu objeto de estudo.

A partir de premissas oriundas da pesquisa do mestrado ${ }^{2}$, defini como hipótese $^{3}$ que se propusesse atividades segundo o "Chaveiro de Significação de Atividades", ou seja, que atendessem a mais de uma categoria da taxonomia de Fink (2007), estaria potencializando as chances da aprendizagem significativa acontecer, sobretudo se estivéssemos trabalhando com problemas relacionados à realidade dos estudantes e utilizando problemas complexos e abertos.

Problemas complexos são relacionados a sistemas, ou seja, não podem ser considerados de forma isolada. Envolvem pessoas e contextos interrelacionados e não pretendem conduzir a soluções exatas, mas a estados melhorados do sistema após o projeto. Problemas abertos são aqueles que podem ser observados e compreendidos de forma diferente por diferentes pessoas, dando margem a diferentes pontos de vista e abordagens, que conduzem a diversas possibilidades de desenvolvimento e solução.

Foram desenvolvidos dois experimentos principais, que foram acompanhados e observados por mais de um semestre.

Primeiro, o exercício projetual da Cidade Submarina buscou criar um ambiente social delimitado pela ficção criada para a Cidade, tecendo relações sociais, políticas, econômicas, educacionais, científicas e holísticas de um povo que morava no fundo do mar. Apesar do curto prazo de execução, três semanas, conseguimos obter um grande engajamento dos estudantes e resultados muito acima de nossas expectativas iniciais. Isso foi possível por termos feito uma pesquisa-intervenção,

1 Questão norteadora: considerando que cada aluno possui um conjunto de competências, habilidades, gostos, referências e experiências próprios, como as demandas de sala de aula podem se tornar significativas para os estudantes, motivando-os positivamente a se engajar em um processo pessoal de aprendizado significativo nas disciplinas de Design Gráfico?

2 Beltrão (2017)

3 Hipótese: A formulação de problemas complexos e abertos, baseados na Taxonomia do Aprendizado Significativo de Fink (2007) e capazes de se relacionar de forma relevante com as realidades diversas dos alunos pode potencializar o aprendizado das disciplinas de Design Gráfico. 
em que a observação do campo permitiu fazer correções e ajustes no processo em tempo de perceber os ganhos e perdas desses ajustes, refletir e fazer novas alterações no processo, como na reflexão-na-ação de Schön (2000).

Desse modo, na segunda aplicação da Cidade Submarina pudemos valorizar o trabalho colaborativo, o processo de geração de ideias divergentes e a criação de modelos das soluções propostas.

O contexto ficcional rompeu com os padrões de percepção dos estudantes e isso os levou a buscarem ideias mais criativas, não usando tanto o repertório que cada um já tinha.

Essa atividade utilizou diferentes categorias da aprendizagem significativa de Fink (2007). As quatro mais relevantes segundo pesquisa realizada com os estudantes, utilizando o instrumento que desenvolvi, foram:

Autorrealização, por terem conseguido em tempo tão curto pensar em ideias que os deixaram felizes;

Aprender a aprender, por terem que buscar informações por conta própria para que o trabalho avançasse e por desenvolverem colaborativamente algumas etapas, trocando conhecimentos e ideias entre si e

Conceitos-chave, que é o próprio conteúdo teórico sobre a metodologia de projeto, conteúdo que normalmente os estudantes não gostam de saber, querem partir direto para a prática nas disciplinas de projeto e

Aplicabilidade, por terem percebido que o conteúdo teórico sobre projetar que iam aprendendo era logo em seguida utilizado no próprio exercício projetual.

Da Cidade Submarina emergiu a percepção do valor do trabalho colaborativo, em diversas etapas ele esteve presente: pesquisas iniciais, geração de ideias, discussão de opções e detalhes, montagem de modelos. A colaboração aconteceu não somente no interior dos grupos de trabalho, mas de forma espontânea entre os grupos.

O estudo do trabalho colaborativo levou-me ao segundo experimento da pesquisa, o Estúdio Livre de Desenho. No Estúdio percebi que tal colaboração havia conduzido os participantes à formação de grupos orientados pelo interesse no estudo de técnicas, temas ou linguagens de desenho e que em tais grupos estava acontecendo com muita potência a aprendizagem significativa.

Estudando os Grupos Operativos de Pichón-Rivère (1986), pude promover também ajustes nas sucessivas edições do Estúdio de Desenho, observando que para o grupo que voluntariamente participava ele estava sendo totalmente relevante e significativo, mesmo sendo uma atividade extraclasse não avaliada.

Estávamos lidando com:

Aprender a aprender, pois os participantes dispunham-se ao encontro semanal, que levava a um processo investigativo do seu desenho pelo exercício frequente e pelo aprendizado colaborativo; 
Aplicabilidade, por perceberem que o que estavam desenvolvendo poderia ser aplicado em seus projetos e projetos pessoais, inclusive com a eventual produção de itens comercializáveis ou para portfólio;

Integração, por eventualmente utilizarem o espaço do Estúdio para desenvolverem os trabalhos da ESPM e

Autorrealização por poderem compartilhar seus avanços com os colegas, por poderem ensinar e pelos desafios que propunham uns aos outros. Essa categoria de aprendizagem significativa era visível nas postagens dos desenhos no Instagram e mesmo pela adesivação de alguns deles ao longo das paredes da sala.

Com o isolamento causado pela pandemia do Covid-19 o Estúdio precisou ser repensado, e isso foi feito também a partir do chaveiro de significação de atividades, focando sobretudo nas categorias autorrealização, aplicabilidade e aprender a aprender.

Desse modo, e conforme relatado nas análises ao longo da tese, posso inferir qualitativamente que a hipótese se confirma: as atividades planejadas segundo a taxonomia de Fink (2007) potencializaram o aprendizado dos estudantes tanto na disciplina de Projeto II (PUC / Cidade Submarina) quanto no aprendizado de desenho (ESPM / Estúdio Livre). Nos dois casos os problemas estiveram relacionados às realidades individuais: na Cidade Submarina houve a identificação e escolha por afinidade de desenvolver um projeto para a área social e no Estúdio Livre houve a identificação com algum aprendizado técnico ou formal de desenho. Na Cidade Submarina os problemas de todas as áreas eram interrelacionados e complexos, pois estavam inseridos no sistema social da cidade, e no Estúdio Livre eram problemas abertos, pois tratavam de investigações pessoais dos estudantes.

\section{Coisas que ficaram no ar (possíveis desdobramentos)}

À medida que no processo da pesquisa-intervenção ia observando os resultados da Cidade Submarina e do Estúdio Livre de Desenho e gerava pequenas hipóteses de aperfeiçoamento para as edições seguintes, fui tendo vez ou outra ideias para atividades e experimentos diferentes.

Quatro dessas ideias foram apresentadas no capítulo 5 como proposições de práticas pedagógicas, porém algumas outras "coisas" ficaram no ar.

A Cidade Submarina deu origem a alguns personagens que eram habitantes dali. Os professores que assumiram esses papéis criaram uma grande teia de explicações para suas atividades e opiniões sobre as mais diversas áreas da cidade, quase sempre de improviso. Um estudante chegou a sugerir que escrevêssemos um livro sobre a cidade, com a história, leis ou crônicas dela. Penso que além do livro, seria possível criar jogos. 
A partir da experimentação da Cidade Submarina em escolas de ensino médio, porém, fiquei imaginando que seria bom criar algum material didático gamificado sobre resolução de problemas para os não-designers.

O Estúdio Livre de Desenho deu origem a um outro projeto semelhante a ele: a Oficina de Experimentação Gráfica, uma oficina de impressão de gravuras que aconteceu por dois semestres em paralelo às aulas extras de serigrafia. A Oficina de Experimentação Gráfica não funcionou com a mesma frequência pois os outros professores envolvidos não puderam comparecer todas as semanas e houve poucos estudantes interessados. Com a consolidação do Estúdio de Desenho, creio que seria possível reformular a Oficina de Experimentação Gráfica e mesmo unir as duas propostas.

Foi no Estúdio Livre de Desenho que surgiu a FEIA (Feira ESPM de Impressos Artesanais - nome escolhido pelos estudantes), feira que daria vazão aos trabalhos que estavam sendo criados pelos participantes, utilizando não somente desenho mas a aplicação de coisas que vinham aprendendo em outras disciplinas, como pintura digital (ilustrações digitais impressas), serigrafia (cartazes, camisetas, ecobags) e diagramação (fanzines, livros). A FEIA precisou ser adiada em função da pandemia do Covid-19. Quando puder acontecer, será no Centro Carioca de Design, na praça Tirandentes.

Um desdobramento já aconteceu a partir dos achados da pesquisa: criei um treinamento para professores na Academia de Professores ${ }^{4}$ da ESPM-Rio em setembro de 2018 e posteriormente, aperfeiçoado, em uma Academia de Professores da ESPM-São Paulo, em fevereiro de $2019^{5}$. No treinamento, apresentei a Taxonomia de Fink (2007) e dois usos propostos aqui, o instrumento que desenvolvi e é útil para medir expectativas e avaliar disciplinas, e o "Chaveiro de Significação de Atividades" que é útil para o planejamento de atividades que favoreçam o aprendizado significativo. Cabe dizer que a primeira parte, até o Chaveiro de Atividades, foi apresentada também no V Fórum Sthem Brasil de Metodologias Ativas, em Palmas / Tocantins em abril de 2019.

\section{Coisas que estão por vir (uns caminhos de retomada)}

A pesquisa investigou a aprendizagem significativa em diferentes aspectos, com dois experimentos que permitiram olhares muito diferentes sobre o processo criativo de estudantes de Design e sobre como os professores podem desenhar suas disciplinas para favorecer o engajamento dos estudantes.

4 As Academias de Professores são treinamentos oferecidos pela ESPM aos professores, iniciativa organizada pelo núcleo de inovações pedagógicas da ESPM-SP e apoiada por representantes locais nas outras unidades.

5 Os slides do treinamento de São Paulo estão nos apêndices. 
De certo modo, partiu dos caminhos de retomada sugeridos no final da pesquisa de mestrado e não os esgotou. Tais caminhos parecem sempre se bifurcar e conduzir a inúmeras possíveis investigações, das quais duas têm atraído mais meu olhar agora:

- A investigação de exercícios de criação colaborativos virtuais

A partir da proposição pedagógica da Cidade Submarina virtual (vide cap.5), surgiu a vontade de pesquisar mais a fundo a colaboração no processo criativo, sobretudo quando se dá remotamente, investigando como o trabalho criativo acontece individualmente, dentro de equipes ou entre equipes. Penso que poderia utilizar a metodologia ativa Aprendizado por Desafios, criada pela Apple para aplicação em ambientes colaborativos virtuais.

- A investigação de exercícios de criação transdisciplinares.

A partir do que foi visto na experiência virtual do Estúdio Livre de Desenho, penso que a experiência poderia ser expandida à criação de quaisquer projetos pessoais, em um ambiente que poderia ser transdisciplinar e virtual. Imagino que poderíamos ter um grupo de professores de diferentes áreas de atuação (como tivemos os habitantes da Cidade Submarina) atuando como tutores do processo e estudantes de diferentes cursos de graduação com interesses variados. Isso permitiria acompanhar processos criativos de diferentes naturezas (dos cursos originários dos estudantes), que teriam orientação de professores de diferentes áreas (oferecendo diferentes olhares e possibilidades de significação) em um ambiente colaborativo, em que os próprios estudantes pudessem ver e opinar nos trabalhos uns dos outros em etapas intermediárias.

Confesso que no semestre passado, 2020.2, aproveitando as oportunidades que a reclusão forçada pela pandemia fez surgir, criei dois embriões de experimentos relacionados a esses tópicos em uma disciplina de Criatividade que leciono na ESPM. Apesar de serem as primeiras aplicações, e de não constituírem ainda uma pesquisa, obtive resultados muito animadores e pretendo iniciar assim que possível o pós-doutorado a partir de uma delas, ou a partir de algo novo que surja dali. 
8 Referências bibliográficas

AJUZ, Joyce. Elaboração de planos de ensino e aprendizagem com base na taxonomia de Bloom. NPP - Núcleo de Práticas Pedagógicas - ESPM. Academia Nacional de Professores. Treinamento ministrado na ESPM-Rio, em julho de 2017.

APPLE, inc. Challenge based learning: take action and make a difference. Research White paper, https://challengebasedlearning.org - 2011.

ARAUJO, Ives Solano. e MAZUR, Eric. Instrução pelos colegas e ensino sob medida: uma proposta para o engajamento dos alunos no processo de ensino-aprendizagem de física. in Cad. Bras. Ens. Física v.30, n.2: p.362-384, ago.2013.

AUSUBEL, David P. The psychology of meaningful verbal learning. New York: Grune \& Stratton, 1963.

BELTRÃO, André Luis F. Estratégias pedagógicas no ensino de design: por uma metodologia ativa. Dissertação de mestrado. Rio de Janeiro: PUC-Rio, 2017.

BESSANT, John. TIDD, Joe. Inovação e empreendedorismo. Porto Alegre: Bookman, 2009.

BLEGER, José. Temas de Psicologia. Entrevista e grupos. São Paulo: Martins Fontes, 1998.

BOMFIM, G. A. Sobre a possibilidade de uma Teoria do Design. Estudos em Design. Ano II, vol.II. Rio de Janeiro, 1994.

BOMFIM, G. A. Sobre a possibilidade de uma Teoria do Design. Estudos em Design. Ano V, vol.II. Rio de Janeiro, 1997.

BROWN, Tim. Design Thinking. Rio de Janeiro: Elsevier, 2010.

CARRASCOZA, João Anzanello. Do caos à criação publicitária: processo criativo, plágio e ready-made na publicidade. São Paulo: Saraiva, 2008.

CROSS, Nigel. Designerly Ways of Knowing. Springer-Verlag London Limited, Londres, 2006.

DA CUNHA, Marcus Vinicius. A Aprendizagem ativa na filosofia educacional de John Dewey. Palestra ministrada aos professores da ESPM-Rio em 10/02/2015.

DAMIANI, Magda F. Sobre pesquisas do tipo intervenção. XVI ENDIPE Encontro Nacional de Didática e Práticas de Ensino - UNICAMP. Campinas: Junqueira\&Marin Editores, Livro 3: p.2882-2890, 2012

DAVID, A. P., MORAIS, M. F., PRIMI, R., MIGUEL, F. K. Metáforas e pensamento divergente: criatividade, escolaridade e desempenho em Ar- 
tes e Tecnologias. Avaliação Psicológica, vol. 13, num.2, agosto 2014, pp. 147-156.

DENIS, Rafael Cardoso. Uma introdução à história do Design. São Paulo: Edgard Blücher, 2000.

DENIS, Rafael Cardoso. Design para um mundo complexo. São Paulo: Cosac Naify, 2013.

DEWEY, John. Vida e Educação. São Paulo: Abril Cultural, 1980.

ECO, Umberto. Como se faz uma tese. Editora Perspectiva, São Paulo, 1977.

ELLET, W. Manual de estudo de caso. Porto Alegre: Bookman, 2008., p-14

FINDELI, Alain. Rethinking Design Education for the 21st Century: Theoretical, Methodological, and Ethical Discussion. in Design Issues: Volume 17, Number 1 Winter 2001, MIT, 2001.

FINK, L. Dee. The Power of Course Design to Increase Student Engagement and Learning. AAC\&U, Winter 2007 peerReview, p13-17. Washington, DC, 2007.

FLECK, Ana Cláudia. Trabalhando em equipes e resolvendo problemas: a aplicação do PBL em sala de aula. Palestra proferida na ESPM-SP. São Paulo, 17 de junho de 2015.

FLUSSER, Vilém. O Mundo Codificado. São Paulo: Cosac \& Naify, 2007. FORTY, Adrian. Objects of desire. London: Thames and Hudson, 1986.

FOUCAULT, Michel. Outros Espaços. Conferência no círculo de estudos arquitetônicos, 1984.

GAYOTTO, Maria L. C. GIFFONI, Vera L. DOMINGUES, Ideli. LOCH, Graciela. DANTAS, Sylvia D. Líder de Mudança e Grupo Operativo. Petropolis: Vozes, 1985.

GIL, Antonio Carlos. Como elaborar projetos de pesquisa. São Paulo: Editora Atlas, 1987.

GONÇALVES, Luiz C. C.. Desenho Industrial Brasileiro? Crírica ao espaço e à forma de atuação. Curitiba: Ed. UFPR, 1981.

GUILFORD, J.P. Creativity, American Psychologist, Volume 5, Issue 9, 444-454, 1950.

IONESCO, Eugene. Relazione per una riunione de scrittori. Turim: Einaudi, 1965.

JAPIASSU, Hilton. Introdução ao pensamento epistemológico. Rio de Janeiro, Francisco Alves, 1977.

LAND, George, JARMAN, Beth. Ponto de Ruptura e Transformação. São Paulo: Cultrix, 1990.

LAKATOS, Eva Maria. MARCONI, Marina de Andrade. Fundamentos de metodologia científica. São Paulo: Editora Atlas, 1991

LMI - Laboratório de Metodologias Inovadoras - UNISAL. Peer Instruction: oficina de metodologia ativa. Treinamento ministrado em Lorena, São Paulo, no primeiro semestre de 2014.

LORIERI, Marcos Antonio. Busca da superação da fragmentação dos saberes nas práticas educativas: aportes históricos e contribuições do pensamento complexo de Edgar Morin. Actas do VII Congresso LUSO-BRASILEIRO de Historia da Educação. Porto, 2008. 
LUNA, Sergio Vasconcelos. Planejamento de Pesquisa. São Paulo: Educ, 1999.

MILLER, J.Abbott. LUPTON, Ellen. ABC da Bauhaus. São Paulo: Cosac Naify, 2008.

MORGROVEJO, Cláudia. GIAMBIAGI, Eliana. NEVES, Eloiza D. PUERTAS, lurutaí B. N. A. RIBEIRO, Luciana M. ABREU, Rita de Cassia M. B. de. CARDOZO, Solange A. FONTE, Rachel Bergman. Introdução à pesquisa-ação. Trabalho acadêmico. Rio de Janeiro: PUC-Rio, 2001

MOREIRA, Marco Antônio. O que é afinal aprendizagem significativa? Qurriculum, La Laguna, Espanha, 2012.

MUNARI, Bruno. Das coisas nascem as coisas. São Paulo: Martins Fontes, 1998.

NETTO, J. Teixeira Coelho. Semiótica, informação e comunicação. São Paulo: Editora Perspectiva, 1980.

NPP - Núcleo de Práticas Pedagógicas - ESPM. Metodologias Ativas. 0 que elas têm em comum? Academia Nacional de Professores. Treinamento ministrado na ESPM-Rio, em julho de 2015.

NPP - Núcleo de Práticas Pedagógicas - ESPM. Metodologias Ativas. Método de caso. Academia Nacional de Professores. Treinamento ministrado na ESPM-Rio, em julho de 2015.

ORDINE, Nuccio. A utilidade do inútil. Rio de Janeiro: Zahar, 2013.

PICHON-RIVERE, Henrique. O Processo Grupal. São Paulo: Martins Fontes, 1986.

PORTASIO, Marcia M.. Aprendizagem baseada em projetos, relato da experiência. Palestra proferida na ESPM-Rio, em agosto de 2014.

RIBEIRO, Flavia Nizia da F. Práticas pedagógicas em cursos de graduação em design: um estudo de caso. 2002. 102p. Dissertação (Mestrado em Design). Pontificia Universidade Católica do Rio de Janeiro (PUC-Rio), Rio de Janeiro.

SANTAELLA, L. O que é semiótica. São Paulo: Brasiliense, 1989.

SANTOS, Sebastião L. A interpretação da piada na perspectiva da teoria da relevância. Tese de doutorado. Curitiba, 2009.

SCHÖN, Donald A. Educando o profissional reflexivo: um novo design para o ensino e a aprendizagem. Porto Alegre: Artmed, 2000

SCOZ, Murilo. Mídias alternativas no caminho do sujeito: uma abordagem semiótica. Tese de doutorado. Rio de Janeiro, 2012

SOMMERMANN, Américo. Pedagogia da Alternância e Transdisciplinaridade in Pedagogia da Alternância: I Seminário Internacional. Cetrans: Bahia, 1999.

TABACARU, Sabina. Uma visão geral das teorias do humor: aplicação da incongruência e da superioridade ao sarcasmo. EID\&A - Revista eletrônica de estudos integrados em discurso e argumentação, Ilhéus, n.9, p.115-136, dez.2015.

TABAK, Tatiana. FABIARZ, Jackeline Lima. (not)Solving (non)problems: Design contributions to Education in a complex world. in Farias, Priscila Lena; Calvers, Anna; Braga, Marcos da Costa \& Schincariol, Zuleica (Eds.). Design frontiers: territories, concepts, technologies. 8th conference 
of the international committee for Design History \& Design Studies. São Paulo: Blucher, 2012.

THE NEW MEDIA CONSORTIUM. Challenge-based learning: an approach for our time. Research report, Austin, Texas, 2009.

THIOLLENT, Michel. Metodologia da pesquisa-ação. São Paulo: Cortez, 2004.

TORRANCE, E. P. Torrance tests of creative thinking. Lexington: Personnel Press, 1966.

TRIPP, David. Pesquisa-ação: uma introdução metodológica. Educação e Pesquisa, São Paulo, v.31, n.3, p.443-466, set/dez.2005

VIANNA, Ysmar. VIANNA, Mauricio. MEDINA, Bruno. TANAKA, Samara. Gamification, Inc.: como reinventar empresas a partir de jogos. Rio de Janeiro: MJV Press, 2013.

WATSON, Charles. Para se sentir vivo. In NACCACHE, Andréa (org.). Criatividade Brasileira: Alex Atala, Fernando e Humberto Campana, Jum Nakao: Gastronomia, design, moda. São Paulo: Manole, 2013.

WECHSLER, Solange M. Avaliação multidimensional da criatividade: uma realidade necessária. Psicol. Esc. Educ. (Impr.) vol.2 no.2. Campinas, 1998.

Páginas na web:

FERNANDES, Nathan. Criatividade se adquire com prática. Disponível em: <https://revistagalileu.globo.com/Ciencia/Neurociencia/noticia/2014/10/criatividade-se-adquire-com-pratica.html>. Acesso em 05 jan. 2021.

JAPIASSU, Hilton. O sonho transdisciplinar. Palestra proferida na aula inaugural do Curso de Pós-graduação em Filosofia, na UBM - Centro Universitário Barra Mansa, 2014. Disponível em: <https://www.recantodasletras.com.br/mensagens/4715006>. Acesso em 14 fev. 2021.

THALHEIMER, Will. Mythical Retention Data \& The Corrupted Cone, 2015. Disponível em <https://www.worklearning.com/2015/01/05/mythical-retention-data-the-corrupted-cone/>. Acesso em 26 dez. 2020.

ROBINSON, Ken. Do schools kill creativity? Palestra proferida no TED Taks, Monterey (California), fev. 2006. Disponível em: <https://www.ted. com/talks/sir_ken_robinson_do_schools_kill_creativity.html>. Acesso em 05 jan. 2021.

SUVIN, Darko (1979) . Estrangement and Cognition. In: Strange Horizons, 2014 . Disponível em: <http://strangehorizons.com/non-fiction/articles/estrangement-and-cognition/>. Acesso em: 11 dez. 2017. 


\section{Apêndices}

Apêndices do capítulo 2: Instrumento de autoavaliação a partir de FINK

CURSO

DISCIPLINA
TURMA

SEMESTRE

\section{ASSINALE NO GRÁFICO ABAIXO SUAS EXPECTATIVAS QUANTO AOS GANHOS QUE TERÁ EM SEU PROCESSO DE APRENDIZAGEM NA DISCIPLINA INDICADA NO TÉRMINO DO SEMESTRE}

Aprender a aprender

Relevância
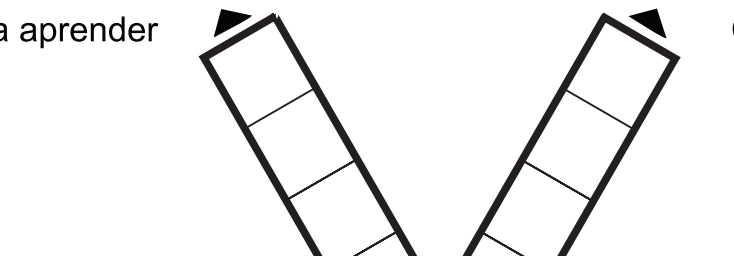

Conceitos-chave

Autorrealização

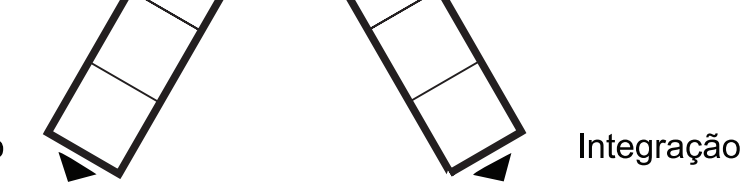

Aplicabilidade

Mudança de ponto de vista

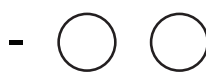

Aprender a aprender: a disciplina deve permitir que você estude por conta própria pontos específicos de seu interesse, em complemento aos conceitos-chave, e o professor deve ser um facilitador de meios e conexões para esse aprendizado complementar.

\section{Conceitos-chave: a disciplina deve} transmitir seus conhecimentos básicos, aqueles que precisam ser entendidos e lembrados, aprendidos.

Aplicabilidade: deve ser possível a aplicação prática, no seu dia-a-dia ou na sua profissão, do que você aprender.
Integração: a disciplina deve se integrar a outras, ou pode ser ponto de conexão entre disciplinas já cursadas, estabelecendo relações e pontes entre teoria e prática.

Autorrealização: você quer ser desafiado e perceber que aprendeu algo por si mesmo, ou interagir de forma diferente com algo que já conhecia, atingindo realizações pessoais.

Relevância: você quer aprender algo que seja útil para sua vida, algo que você continue utilizando/estudando.

Mudança de ponto de vista: o que você aprender deve trazer novos modos de ver ou sentir algo, levando-o a rever valores, pontos de vista, preconceitos e interesses.

Formulário para marcação de expectativas de alunos e professores no início do semestre 
CURSO

DISCIPLINA

TURMA

SEMESTRE

Aprender a aprender

Relevância

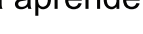

Aprender a aprender: a disciplina permitiu que você estudasse por conta própria pontos específicos de seu interesse, em complemento aos

conceitos-chave, e o professor atuou como facilitador de meios e conexões para esse aprendizado complementar?

Conceitos-chave: a disciplina transmitiu seus conhecimentos básicos, aqueles que precisam ser entendidos e lembrados, aprendidos?

Aplicabilidade: é possível a aplicação prática, no seu dia-a-dia ou na sua profissão, do que você aprendeu?
Integração: a disciplina integra-se a outras, ou pode ser ponto de conexão entre disciplinas já cursadas, estabelecendo relações e pontes entre teoria e prática?

Autorrealização: você se sentiu desafiado e percebeu que aprendeu algo por si mesmo, ou interagiu de forma diferente com algo que já conhecia, atingindo realizações pessoais?

Relevância: o que você aprendeu será útil para sua vida? Você continuará utilizando/estudando isso?

Mudança de ponto de vista: você mudou positivamente seu modo de ver ou sentir algo, engajou-se em alguma causa ou reviu valores, pontos de vista, preconceitos e interesses?

Formulário para autoavaliação de alunos no final do semestre 


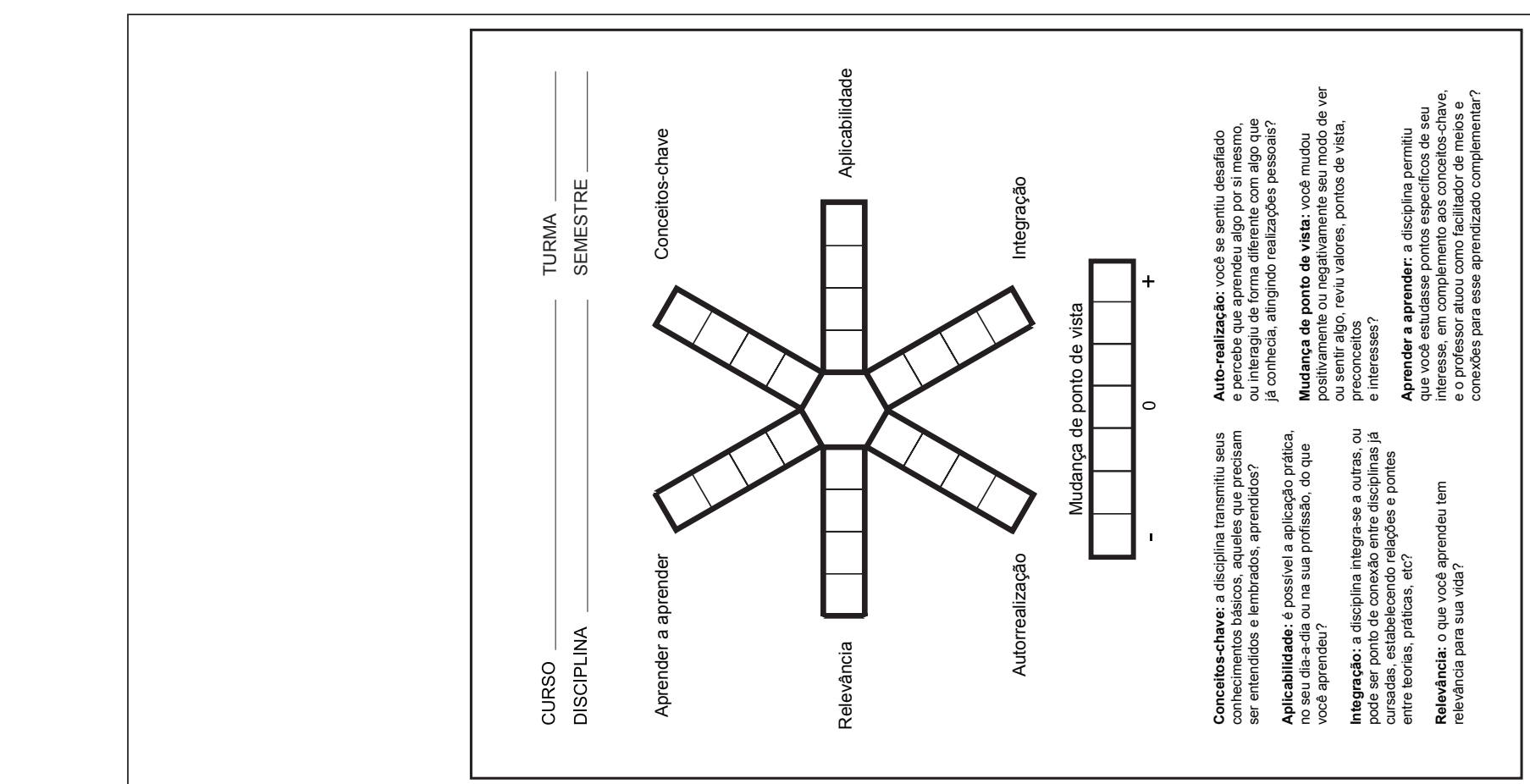

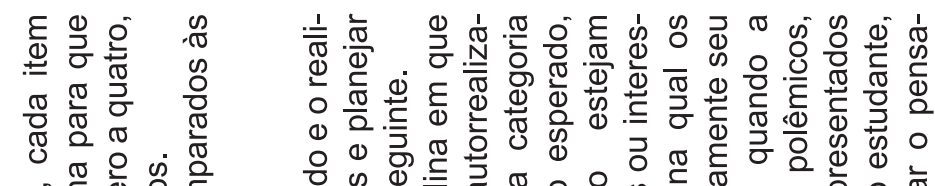

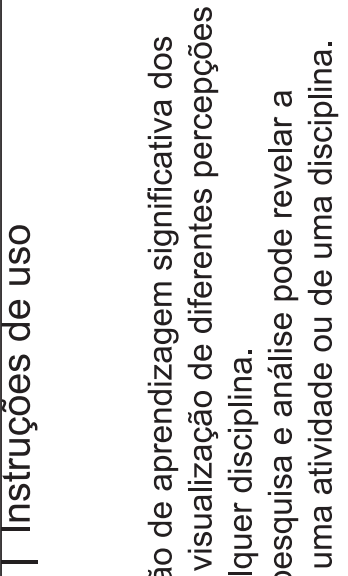

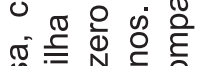

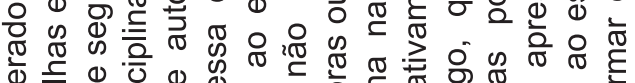

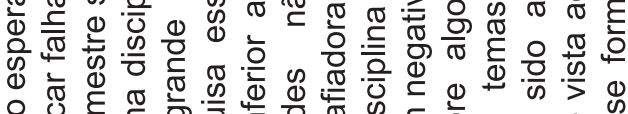

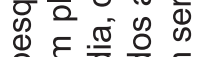

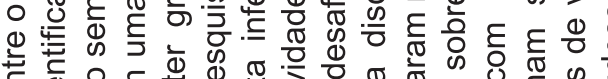
중 율 \&

일

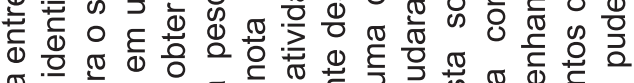

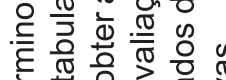

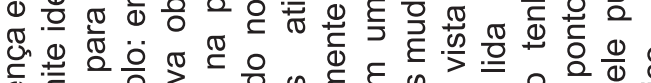

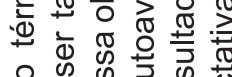

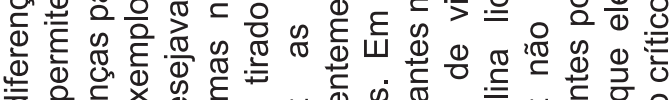

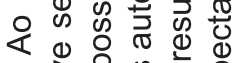

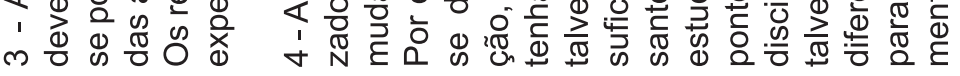

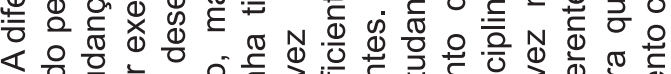

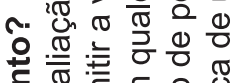

잉

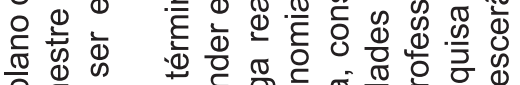

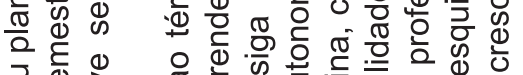

बं

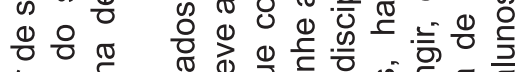

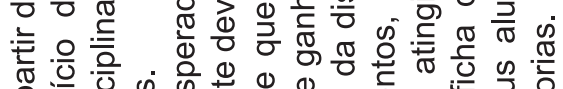

응 중

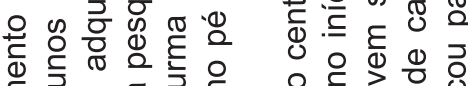

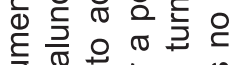

के

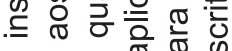

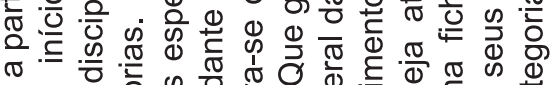

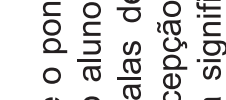

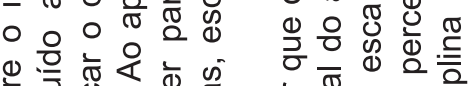

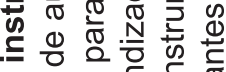

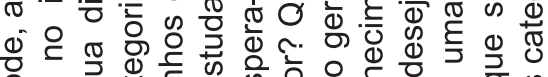

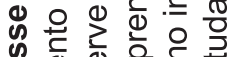

.

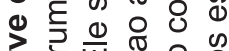

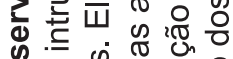

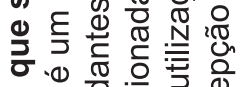

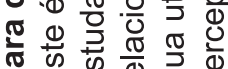

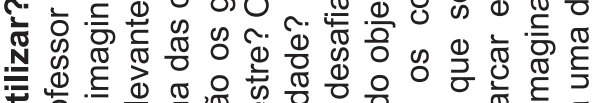

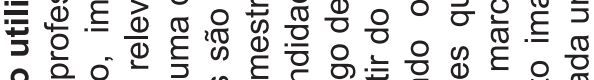

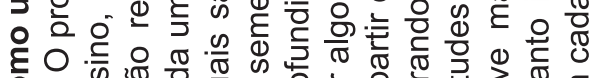

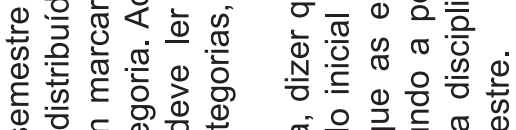
क 융

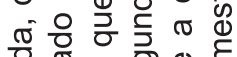

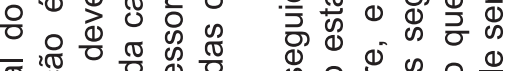

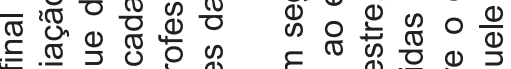

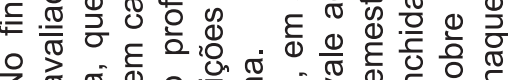

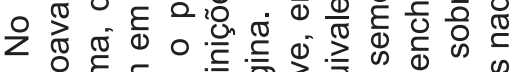

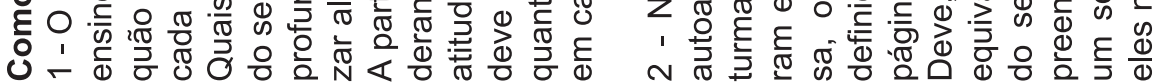



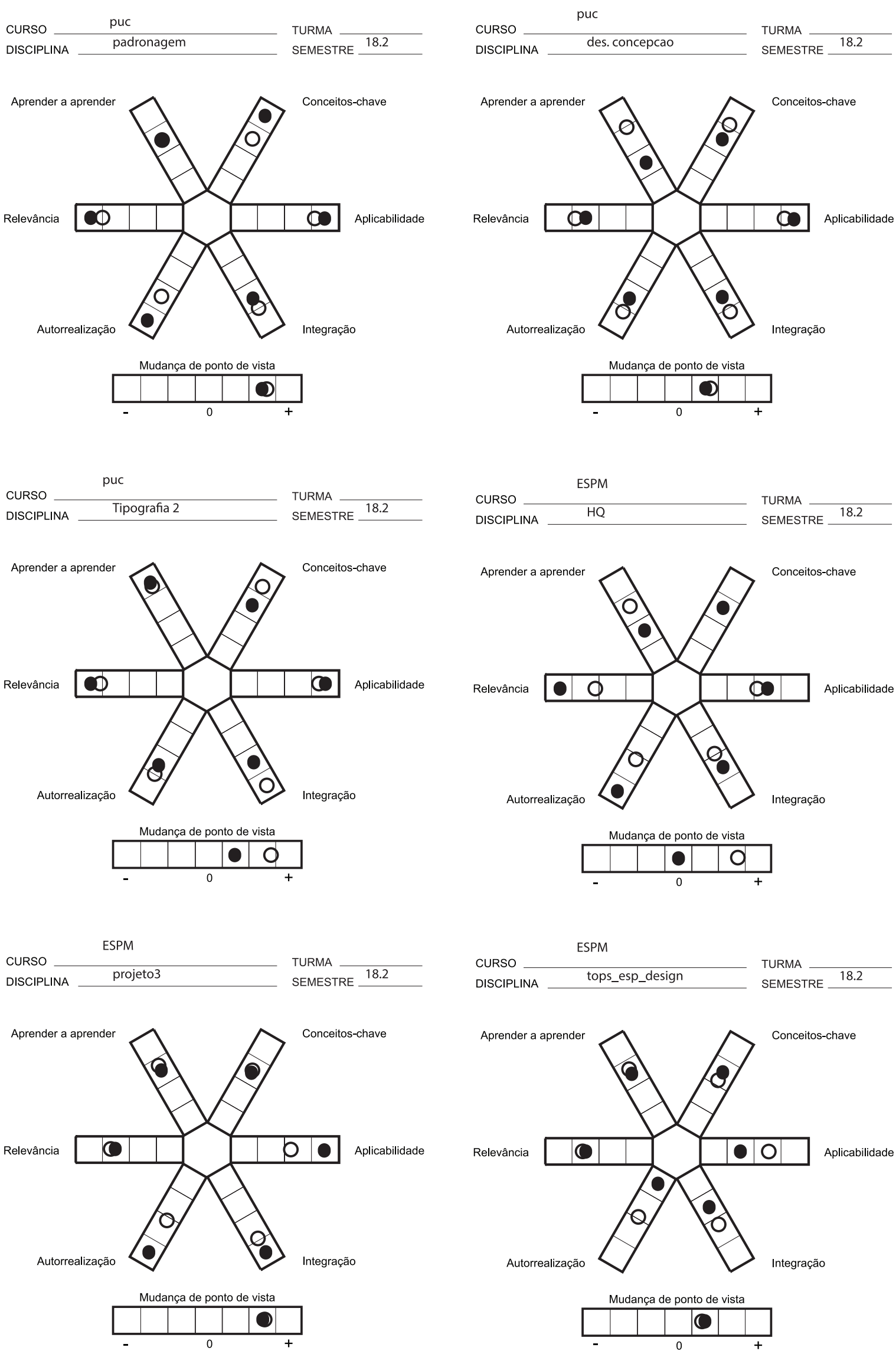

previsao: 26/08/2018 última pesquisa: 02/12/2018

previsto $\mathrm{O}$ Resultado pesquisa

Comparação previsto x realizado no semestre 2018.2 

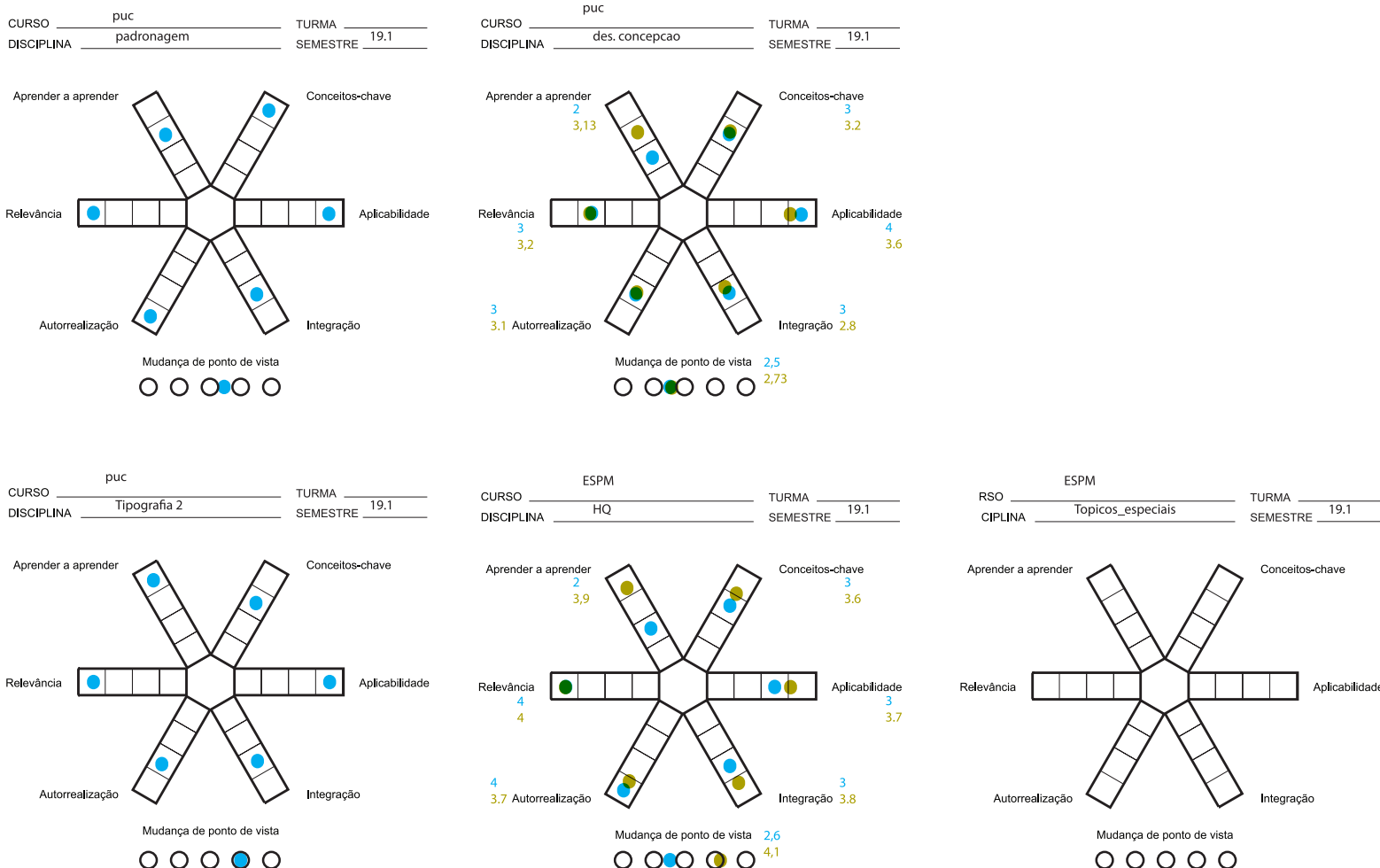

$00000 \mathrm{O}^{4,1}$

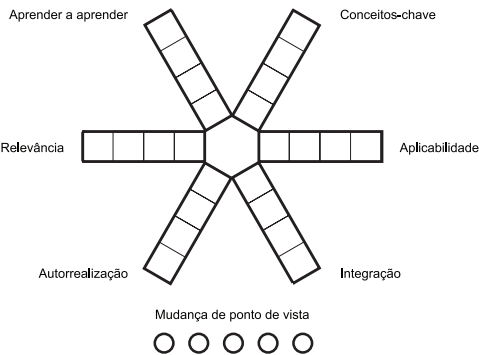

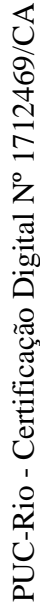
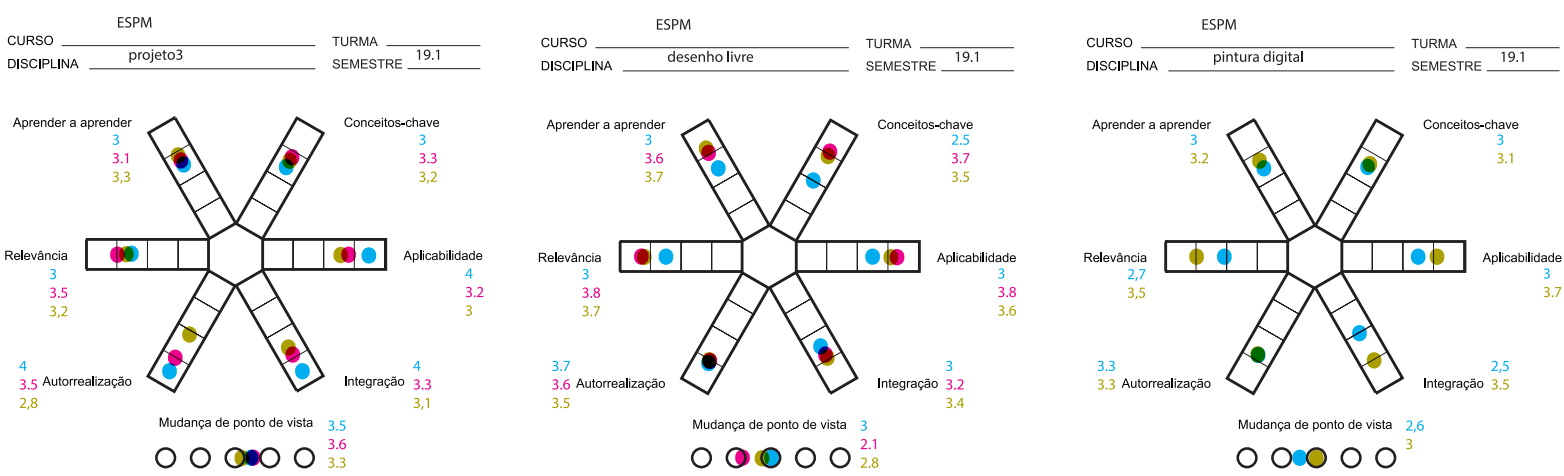

previsao: fev $/ 2019$ expect alunos: $f e v / 2019_{\text {pesquisa: } j u n / 2019}$

expectativa
alunos

resultado
pescuisa final 


\section{Apêndices do capítulo 3: Cidade Submarina}

\section{CIDADE SUBMARINA}

Oduvaldo Aldo I enviado especial

Alguns dizem que a primeira grande crise econômica brasileira veio dar às nossas praias junto com a família real portuguesa, em 1808. A essa, tantas outras sucederam até o presente, e novamente nos vimos mergulhados até o pescoço num caos econômico.

Foi num momento assim que uma comunidade de cientistas e livre pensadores brasileiros resolveu mergulhar de fato, e não voltar mais: em pleno congelamento de preços e hiperinflação da era Sarney, os quase 50 amigos resolveram construir uma nação submarina.

Prodígio da técnica, em pouco mais de um ano foi toda projetada, construída e habitada. A cidade é autossuficiente, produz seu próprio oxigênio através da quebra das moléculas de água, que também é dessalinizada para abastecimento e irrigação. A energia é gerada pelo movimento das marés e o solo marinho foi tratado para receber plantações e para servir de pasto ao gado e animais de criação.

É interessante ressaltar as inovadoras e incríveis realizações da engenharia genética: através da combinação de espécies, obtiveram novas raças de animais que conseguem respirar debaixo d'água, assim não precisam consumir o oxigênio do Domo Principal.

A arquitetura é plana, com prédios de poucos andares (pergunto-me o porquê disso) e casas térreas, as construções se espalham por uma série de domos que vão se conectando a partir do Domo Principal, aquele que foi originalmente erguido há cerca de 30 anos, e abrigam uma população de quase mil pessoas que optaram por morar no fundo do mar ou que lá nasceram. Os domos são interligados por passagens tubulares de diversos diâmetros, adequadas à transferência de pessoas, objetos, alimentos ou veículos.

Os novos habitantes da Cidade Submarina são pessoas vindas principalmente da superfície, porém já há uma geração de jovens nascidos lá, o mais velho já com 25 anos de idade, e recentemente mudou-se para lá uma mulher vinda de outra nação similar, que até então era desconhecida.

Tal senhora é um grande mistério. Aos poucos, se integra à vida local, mas só consegue se comunicar por desenhos, e ninguém conhece sua história nem a civilização de onde veio.

O conselho de anciãos, composto por poucos membros remanescentes do grupo de fundadores, administra a cidade como um grupo de gerentes. Há o gerente das comunicações, o dos transportes, o da agricultura, o da ciência e pesquisa e o da cultura.

Todos os habitantes são felizes (ou parecem ser), têm saúde, escolas e arte.

Pediram-me que não divulgasse onde ficam localizados, pois temem a invasão de turistas e eventuais levas de imigrantes fugindo da atual crise. Não são xenófobos, adoram se comunicar com o nosso mundo, têm, no entanto, uma limitação de espaço e de recursos. A Cidade Submarina não suportaria um rápido crescimento, e um colapso representaria o seu fim.
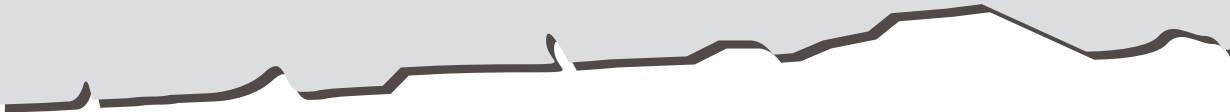


\section{CIDADE SUBMARINA AMEAÇADA}

Oduvaldo Aldo I enviado especial

Há poucas semanas esse diário publicou uma matéria sobre a agora famosa Cidade Submarina, e agora faz-se necessário ampliar o texto a um apelo - salvem-na!

Para aqueles que não leram a matéria anterior, trata-se de uma nação no fundo do mar onde tudo é, ou parece ser, perfeito. Materializando nossos sonhos utópicos, na Cidade Submarina não é necessário usar dinheiro, não há escassez de alimento, água, saúde, educação ou diversão.

Apesar de termos ocultado sua localização, soubemos por fontes locais que nas últimas duas semanas mais de cem pessoas pediram asilo no Grande Portal, entrada do Domo Principal. Tal contingente, vindo em submarinos improvisados, já representa cerca de dez por cento da população da cidade, e está causando desequilíbrio no dia-a-dia.

Foram relatados problemas com as comunicações, com o abastecimento de ar e de água, com os transportes e com os serviços municipais, o que tem trazido considerável estresse aos pacatos moradores.
Em entrevista exclusiva, o gerente de infraestrutura nos garantiu que em pouco tempo tudo será normalizado, e que os novos cidadãos serão totalmente integrados à Cidade. Desconfiamos, porém, que isso pode ser falso - nossas fontes relataram que tem aumentado consideravelmente o nível de gás carbônico da cidade, que as plantações do domo agrícola não estão conseguindo se recompor no mesmo ritmo em que são consumidas e que as passagens de acesso ao mundo externo (o Grande Portal sobretudo) estão desgastadas, apresentando problemas de vedação.

Os cientistas fundadores, agora reduzidos a pouco mais de dez anciãos, tem se reunido no conselho que administra a cidade, no entanto receamos que suas combalidas mentes não sejam suficientes para redesenhar a comunidade para adequá-la aos desafios que se apresentam. Fazemos portanto um apelo àqueles que puderem contribuir com ideias para o conselho dos anciãos, enviem cartas à nossa redação. E alertamos àqueles que ainda planejavam esconder-se lá: as fronteiras estão fechadas.

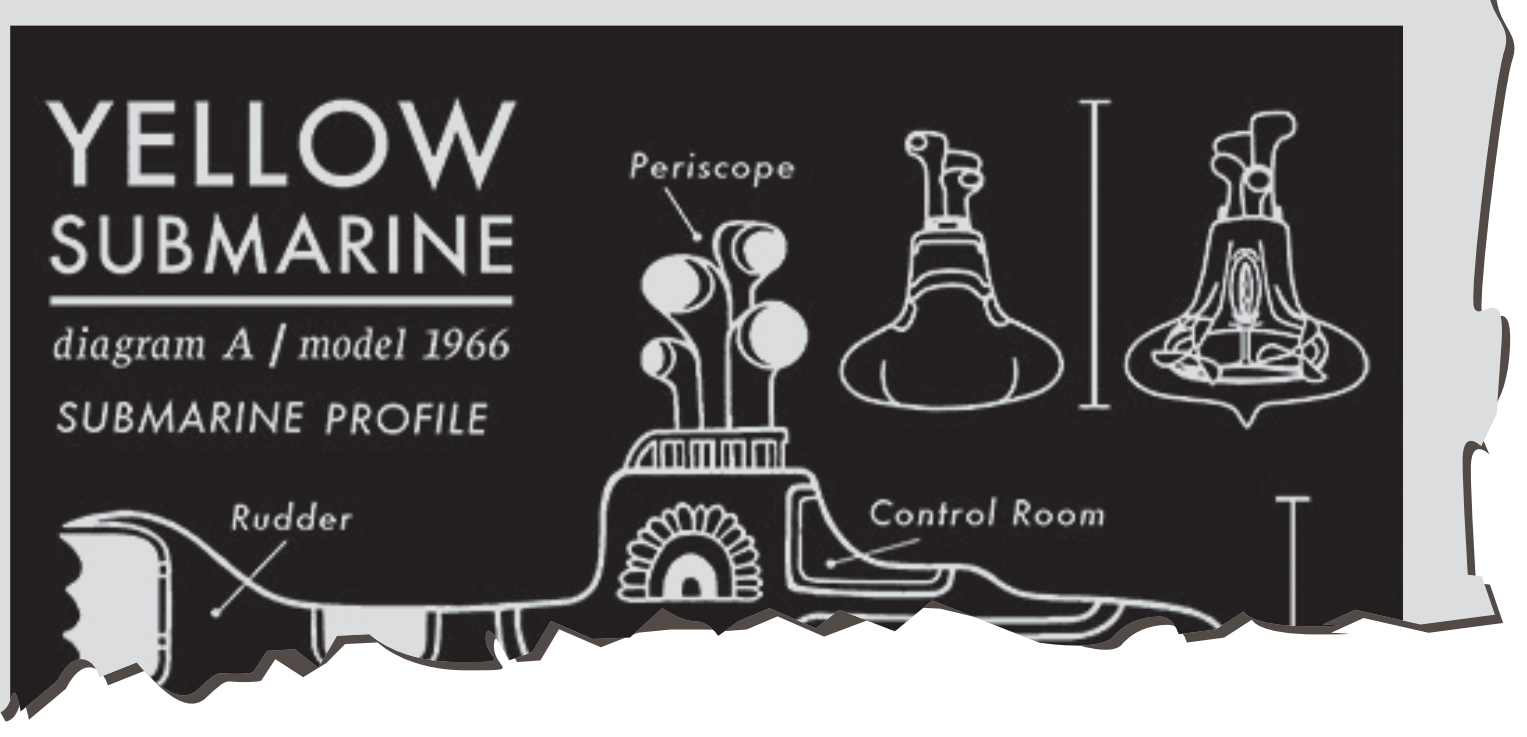

CIDADE SUBMARINA AMEAÇADA

Matéria publicada em 10 de janeiro de 2018 Jornal do Sudeste 
Carta recebida em 12/01/2018

Sr. Francisco I comunidade agrícola Agroprata

Sugiro ao Conselho dos Anciãos fazer contato com os estudantes de Design da PUC. Há alguns anos estiveram aqui na Agroprata e tiveram ideias incríveis, revolucionárias.

Procurem a prof. Roberta Portas.

Sugiro também plantarem caquis e bananas na Cidade Submarina, ofereço-me para mostrar como se faz.

Caro sr. Francisco,

Obrigado pelas sugestões, foram encaminhadas ao Conselho dos Anciãos, bem como o telefone e email da professora Roberta, que descobrimos na internet.

Carta recebida em 13/01/2018

Maurício I vendedor de Matte em Ipanema

Sei que naum inscrevo bem mais sugiro falarem cos estudantes de desing da PUC, estiveram aqui de olho nas minhas coisa, disseram que eram gambiarras e inventaram uma roupa sinistra pra mim.

Caro sr. Maurício,

Obrigado pelas sugestões, foram encaminhadas ao Conselho dos Anciãos. Sugerimos procurar agora a professora Fátima, também na PUC, que pode continuar a ajudá-lo.
Carta recebida em 14/01/2018

Otávio I motorista Uber

Senhor jornalista, como se faz para chegar à Cidade Submarina? Como eles viajam? Como a estrangeira citada em sua matéria chegou até lá? Creio que posso contribuir com boas soluções para transporte se eu puder marcar uma reunião com o conselho dos anciãos.

Caro sr. Otávio,

Infelizmente não sabemos responder a essas questões e não podemos, por questões éticas, dar maiores informações. Sugerimos uma investigação pessoal a respeito.

Carta recebida em 15/01/2018

Margarida I Lisboa - Portugal

Gostaria primeiro de manifestar minha inquietação quanto às descabidas alusões à família real portuguesa como fonte de crises no Brasil. Se calhar, foi o Brasil a fonte de crises em Portugal.

Bom, ao que interessa, tenho um palpite sobre a estrangeira misteriosa. Mas como o palpite é meu, cá está ele.

Passar bem.

Cara sra. Margarida,

Em momento algum foi nossa intenção ofender à senhora ou a seus concidadãos. Por favor compartilhe as informações que tem sobre a estrangeira, isso pode lançar alguma luz sobre como poderíamos ajudá-la a se comunicar com os demais moradores. 
QUEMÉ QUEM - pessoal designado para a reunião com a PUC

\section{André}

Membro do conselho dos anciãos, um dos fundadores. Também supervisiona os gerentes da cidade $e$ acumula o cargo de gerente das comunicações

\section{Guto}

Gerente da cultura e lazer. Desica-se a alimentar as mentes dos habitantes com arte e cultura, incentivando a criatividade, e por criar atividades que preservem sua forma física. Dirige o teatro municipal, é responsável por shows e grandes eventos, e pela Rádio Cidade Submarina.

\section{Guilherme}

Investidor que patrocina atualmente os centros de pesquisa da Cidade Submarina. Qual serão seus reais interesses?

\section{João Victor}

Gerente dos transportes. Responsável por construir e operar os meios de transporte internos e externos, garantindo a eficiente circulação de pessoas e mercadorias e pela manutenção dos portais de entrada da Cidade.

$\left\{\begin{array}{l}\text { Cláudia } \\ \text { Pesquisadora de padrões marinhos e estilista da cidade submarina. Está desenvol- } \\ \text { vendo um novo conceito de moda com roupas frescas refletem a luz interior das } \\ \text { pessoas, ajudando a iluminar a cidade, e gostaria de criar roupas impermeáveis para } \\ \text { viagens na água. } \\ \text { Luiz } \\ \text { Mais velho jovem nascido na cidade. Gerente da pesquisa e ciência. Coordena um lab- } \\ \text { oratório (LIRV) que pesquisa novas tecnologias relacionadas à água. Também coorde- } \\ \text { na pesquisas de comunicação, de transporte e de genética. } \\ \text { Responsável pelas novidades tecnológicas, atualizando a Cidade submarina quan- } \\ \text { to ao que desenvolve na superfície. Pesquisa a transferência de energia sem fio a } \\ \text { grandes distâncias. É também responsável pela rede de dados da Cidade Submarina } \\ \hline\end{array}\right.$

Ata do conselho dos Anciãos 


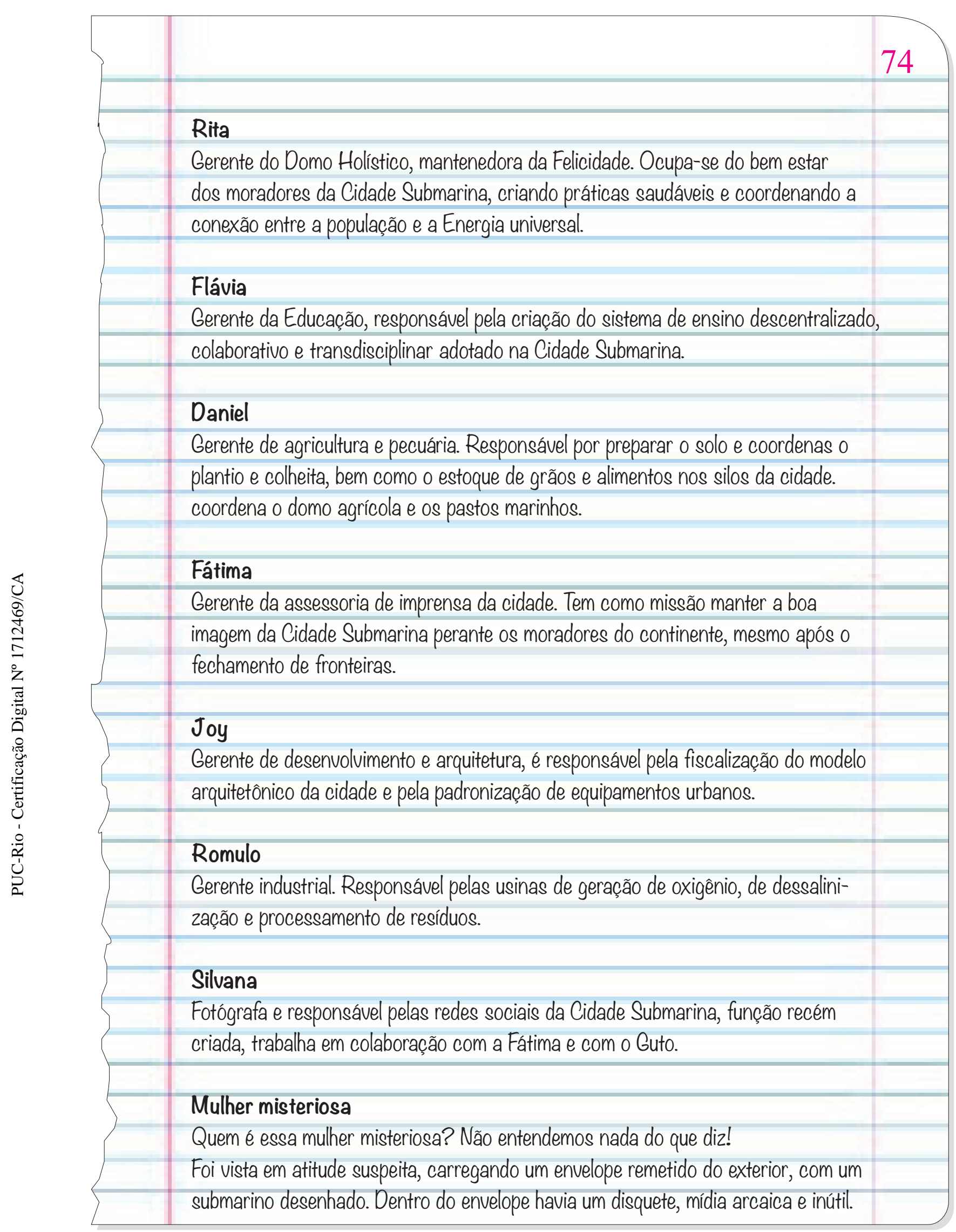




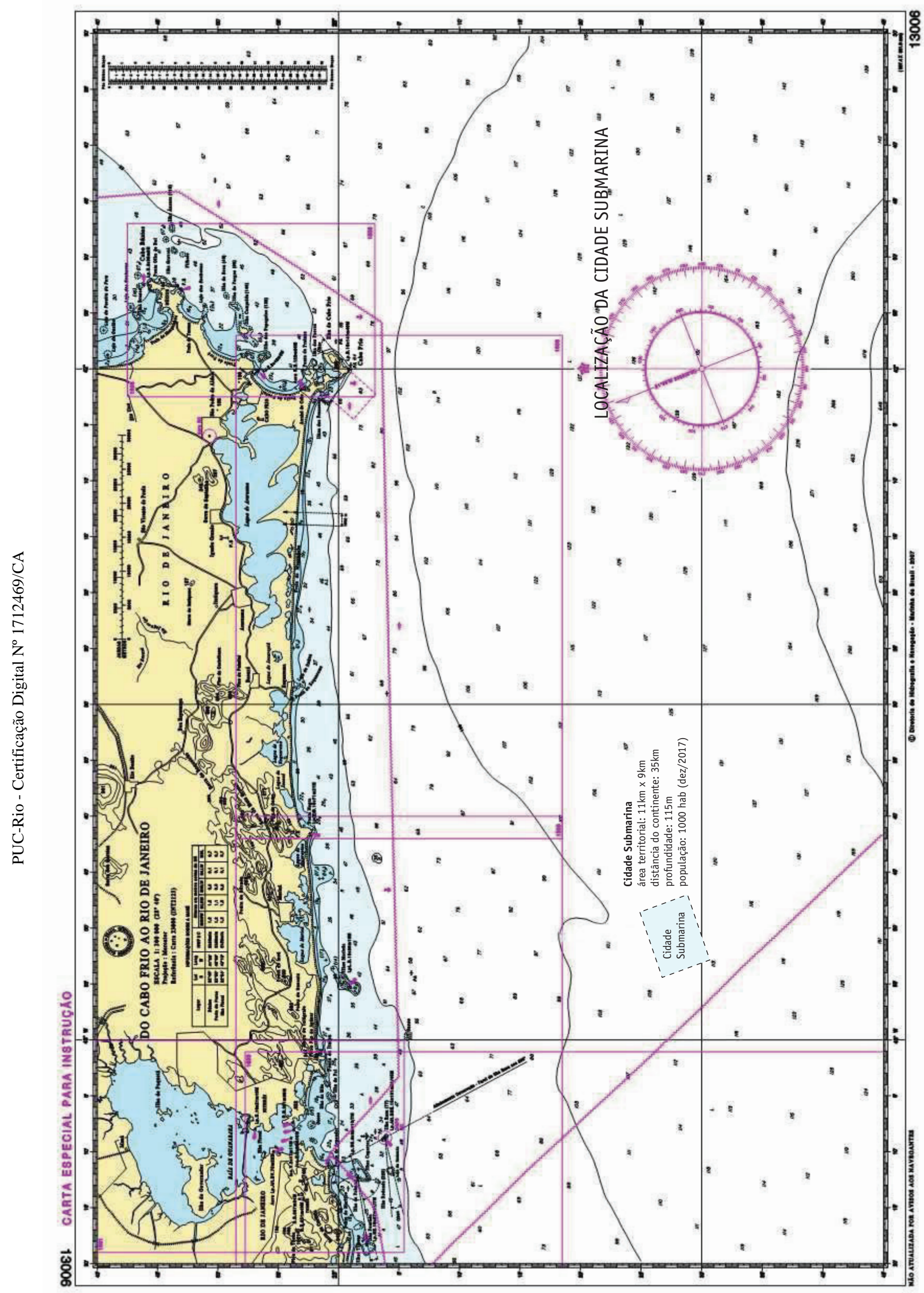

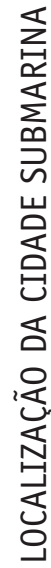



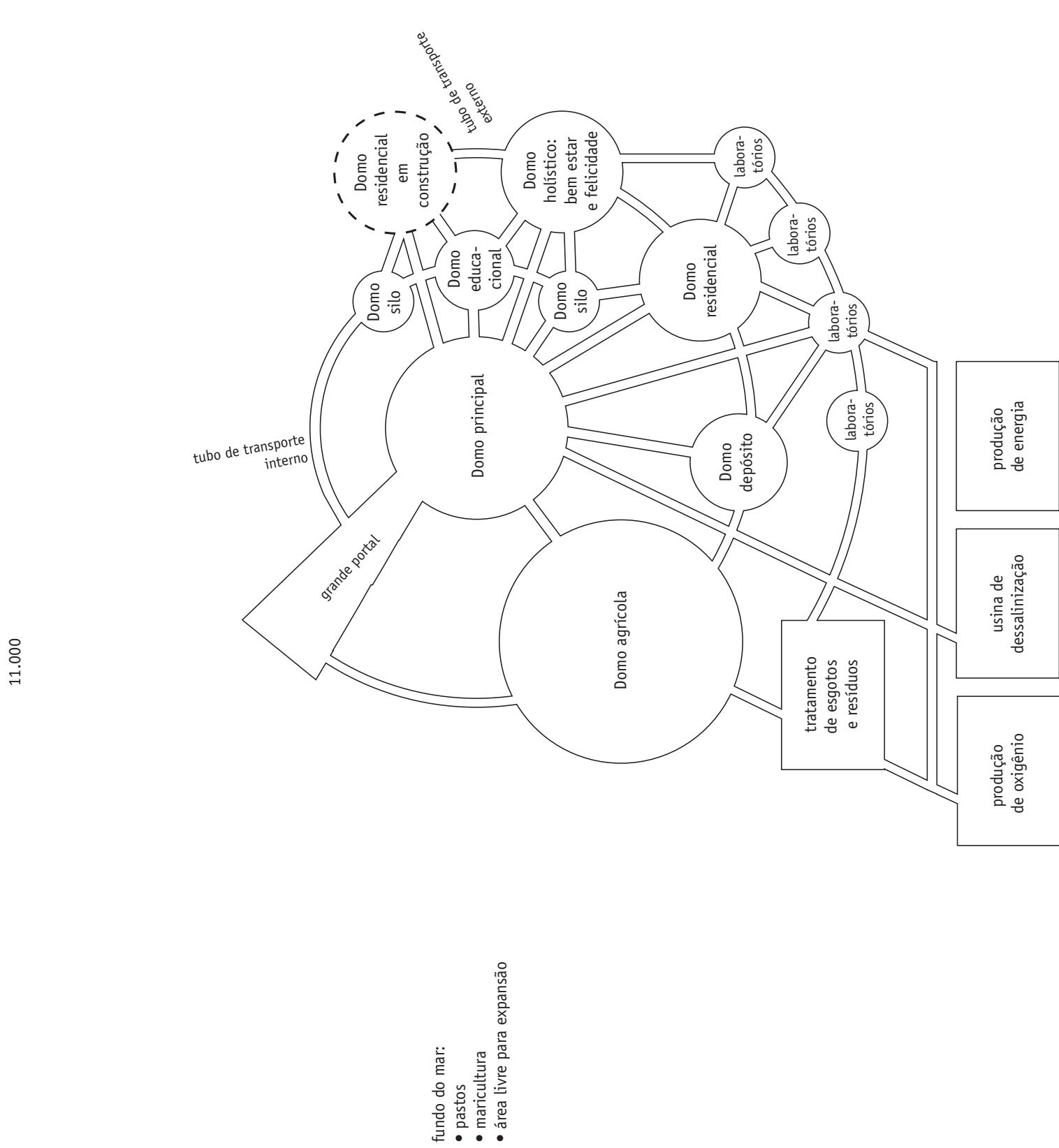

$000 \%$

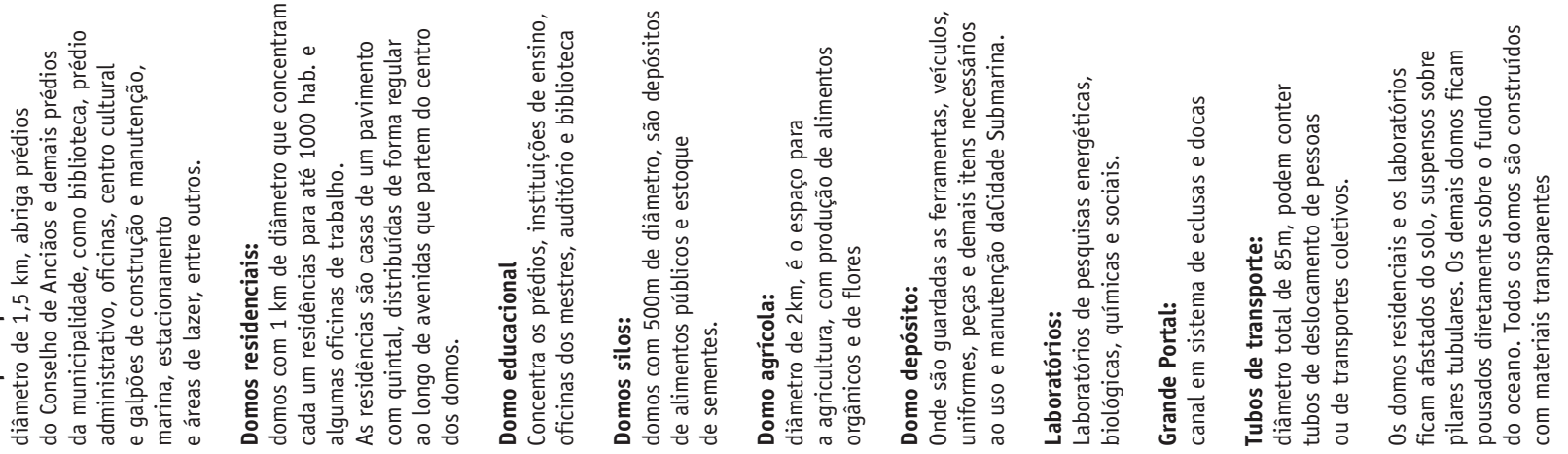


ऊid-opjoñont!s situação-pro op̧̃oñt!s situação-problen pnt!̣ situação-problema situação-problema Duə| ação-problema Duə|qoıd o-problema Duə|qoıd-oD

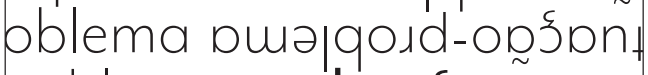
ma euə|qoıd-oef́cent!s sit

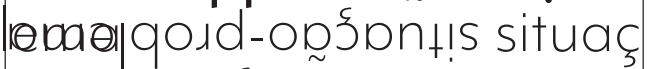
| qoıd-opơnonł! situação-

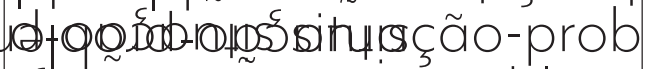
zริoñt!̣ situação-problem it!̣ situação-problema Du ituação-problema Duə|q ção-problema DUə|qoıd- opjont!s /Otəlqo objeto/s eśnenł!s /ołə!̣o objeto/ situ p̧ont!s /Otəlqo objeto/ situc onı!s /Otəlqo objeto/ situaç h+! /Otə!qo objeto/ situaçã Is /Otə!qo objeto/ situação /Otəlqo objeto/ situação ol ptəlq objeto/ situação ok əlqo objeto/ situação obse qo objeto/ situação obsery o objeto/ situação observa objeto/ situação observad. bjeto/ situação observad.

\section{TRANSFORMAR}

\section{CRIAR}

\section{APRIMORAR}

\section{RESSIGNIFICAR}

\section{MELHORAR}

\section{PLANEJAR}


Apêndices do capítulo 5: plano de aulas da disciplina proposta no item 5.2

\begin{tabular}{|c|c|c|c|c|}
\hline $\begin{array}{l}\text { Encontro / } \\
\text { atividade }\end{array}$ & $\begin{array}{l}\text { Atividade } \\
\text { prévia }\end{array}$ & $\begin{array}{l}\text { Registro/ } \\
\text { observação }\end{array}$ & Pontos de atenção & $\begin{array}{l}\text { Metodologias } \\
\text { e métodos }\end{array}$ \\
\hline $\begin{array}{l}1-\text { Sensibiliza- } \\
\text { ção e imersão no } \\
\text { universo ficcional }\end{array}$ & $\begin{array}{l}\text { Leitura do livro } \\
\text { Admirável mun- } \\
\text { do novo }\end{array}$ & $\begin{array}{l}\text { Observador não } \\
\text { partic ip a n te } \\
\text { neutro registra } \\
\text { as reações dos } \\
\text { participantes } \\
\text { (bolsista?) } \\
\text { Observador par- } \\
\text { ticipante faz } \\
\text { interferências } \\
\text { como mediador } \\
\text { dos grupos } \\
\text { Registro foto- } \\
\text { gráfico do de- } \\
\text { senvolvimento } \\
\text { Registro em vi- } \\
\text { deo das apresen- } \\
\text { tações } \\
\text { Análises sema- } \\
\text { nais do desen- } \\
\text { volvimentocom } \\
\text { a presença de } \\
\text { obs ervadores } \\
\text { participantes e } \\
\text { não participan- } \\
\text { te, para eventual } \\
\text { ajuste no plane- } \\
\text { jamento da se- } \\
\text { mana seguinte. }\end{array}$ & $\begin{array}{l}\text { No início: criar um grupo ativo, } \\
\text { em que todos os participantes } \\
\text { tenham sensação de pertenci- } \\
\text { mento. Para isso, talvez criar um } \\
\text { grupo de mensagens do grupo, } \\
\text { uma pasta compartilhada para } \\
\text { armazenarem arquivos ou um } \\
\text { grupo do Facebook onde possam } \\
\text { comentar e postar imagens. } \\
\text { Análises semanais do desenvol- } \\
\text { vimento, com a presença de ob- } \\
\text { servadores participantes e não } \\
\text { participante, para eventual ajus- } \\
\text { te no planejamento da semana } \\
\text { seguinte. } \\
\text { Observar os "papéis" dentro } \\
\text { dos grupos: porta-voz, líder de } \\
\text { mudança, lider negativo. } \\
\text { Observar resistência / ansie- } \\
\text { dade/ angústia e se necessário } \\
\text { replanejar atividades seguintes } \\
\text { para reequilibra-los } \\
\text { Cada encontro precisa ter um "fe- } \\
\text { chamento", uma síntese, e prepa- } \\
\text { ração para o encontro seguinte. } \\
\text { Deixar as pautas sempre aber- } \\
\text { tas, para que as propostas ve- } \\
\text { nham a partir dos participantes. }\end{array}$ & Storytelling \\
\hline $\begin{array}{l}2 \text { - Imersão } \\
\text { no universo } \\
\text { ficcional }\end{array}$ & $\begin{array}{l}\text { Criação de } \\
\text { experiência } \\
\text { imersiva }\end{array}$ & & & $\begin{array}{l}\text { Storytelling, } \\
\text { brainstorming }\end{array}$ \\
\hline $\begin{array}{l}3-\text { Pesquisa } 1 / \\
\text { referências }\end{array}$ & $\begin{array}{l}\text { Pesquisar e tra- } \\
\text { zer referências }\end{array}$ & & & Pesquisa \\
\hline $\begin{array}{l}4-\text { Pesquisa } 1 / \\
\text { referências }\end{array}$ & & & & Pesquisa \\
\hline $\begin{array}{l}5 \text { - Criação } \\
\text { colaborativa }\end{array}$ & $\begin{array}{l}\text { Trazer } \\
\text { esboços iniciais }\end{array}$ & & & $\begin{array}{l}\text { Brainstor- } \\
\text { ming } \\
\text { Aprendizado } \\
\text { por grupos }\end{array}$ \\
\hline
\end{tabular}




\begin{tabular}{|c|c|c|c|c|}
\hline $\begin{array}{l}\text { Encontro / } \\
\text { atividade }\end{array}$ & $\begin{array}{l}\text { Atividade } \\
\text { prévia }\end{array}$ & $\begin{array}{l}\text { Registro/ } \\
\text { observação }\end{array}$ & Pontos de atenção & $\begin{array}{l}\text { Metodologias } \\
\text { e métodos }\end{array}$ \\
\hline $\begin{array}{l}6 \text { - Criação cola- } \\
\text { borativa }\end{array}$ & $\begin{array}{l}\text { Desenvolver- } \\
\text { concepts e } \\
\text { investigar } \\
\text { técnicas/temas }\end{array}$ & & & \\
\hline $\begin{array}{l}7 \text { - Criação cola- } \\
\text { borativa }\end{array}$ & & & & \\
\hline $\begin{array}{l}8 \text { - Apresentação } \\
\text { participativa }\end{array}$ & $\begin{array}{l}\text { Trazer esboços / } \\
\text { concepts / ilus- } \\
\text { trações reunidas } \\
\text { apontando um } \\
\text { caminho de de- } \\
\text { senvolvimento }\end{array}$ & & & $\begin{array}{l}\text { apresentações } \\
\text { participativas }\end{array}$ \\
\hline $\begin{array}{l}9 \text { - Pesquisa e } \\
\text { desenvolvimento }\end{array}$ & $\begin{array}{l}\text { Trazer o desen- } \\
\text { volvimento } \\
\text { da semana }\end{array}$ & & & $\begin{array}{l}\text { Aprendizado } \\
\text { por grupos }\end{array}$ \\
\hline $\begin{array}{l}10 \text { - Pesquisa e } \\
\text { desenvolvimento }\end{array}$ & & & & \\
\hline $\begin{array}{l}11 \text { - Pesquisa e } \\
\text { desenvolvimento }\end{array}$ & & & & \\
\hline $\begin{array}{l}12 \text { - Pesquisa e } \\
\text { desenvolvimento }\end{array}$ & & & & \\
\hline $\begin{array}{l}13 \text { - Pesquisa e } \\
\text { desenvolvimento }\end{array}$ & & & & \\
\hline $\begin{array}{l}14 \text { - Pesquisa e } \\
\text { desenvolvimento }\end{array}$ & & & & \\
\hline $\begin{array}{l}15 \text { - Apresenta- } \\
\text { ção Final }\end{array}$ & $\begin{array}{l}\text { Preparação } \\
\text { da apresentação }\end{array}$ & $\begin{array}{l}\text { Filmar as } \\
\text { apresentações } \\
\text { Autoavaliação } \\
\text { Fink }\end{array}$ & $\begin{array}{l}\text { Objetivo: qualidade da tarefa } \\
\text { (grupos operativos) e não con- } \\
\text { clusão da tarefa (grupos autori- } \\
\text { tários) }\end{array}$ & \\
\hline $\begin{array}{l}16 \text { - pós-apresen- } \\
\text { tação }\end{array}$ & & $\begin{array}{l}\text { Recolher } \\
\text { relatos dos } \\
\text { participantes }\end{array}$ & $\begin{array}{l}\text { Análise final da autoavaliação, } \\
\text { dos resultados obtidos e dos re- } \\
\text { latos. }\end{array}$ & $\begin{array}{l}\text { Entrevistas } \\
\text { semi } \\
\text { estruturadas } \\
\text { focalizadas }\end{array}$ \\
\hline
\end{tabular}




\section{Apêndices do capítulo 6: treinamento oferecido a professores da ESPM-SP, um dos desdobramentos da pesquisa.}
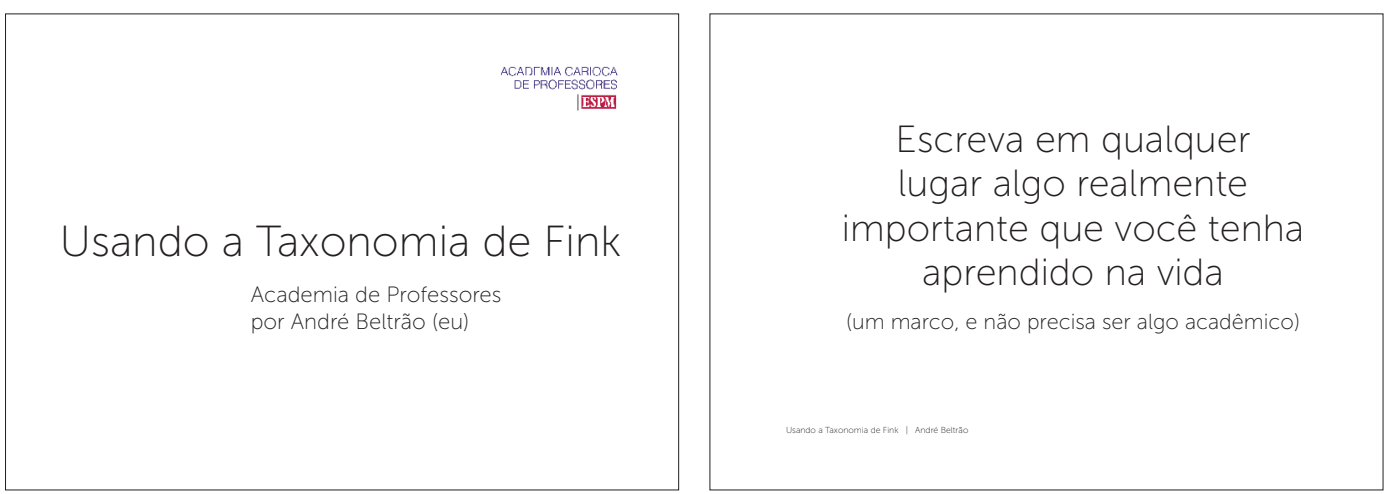

Eu lembrei de quando aprendi a desenhar cabelos..tinha uns 6 anos

A aprendizagem significativa acontece quando o estudante relaciona novas informações a algum aspecto relevante pré-existente em sua estrutura cognitiva, modificando-se enquanto aprende pela ressignificação de conhecimentos, criando condições de aprender novas informações em um processo progressivo de construção do conhecimento.
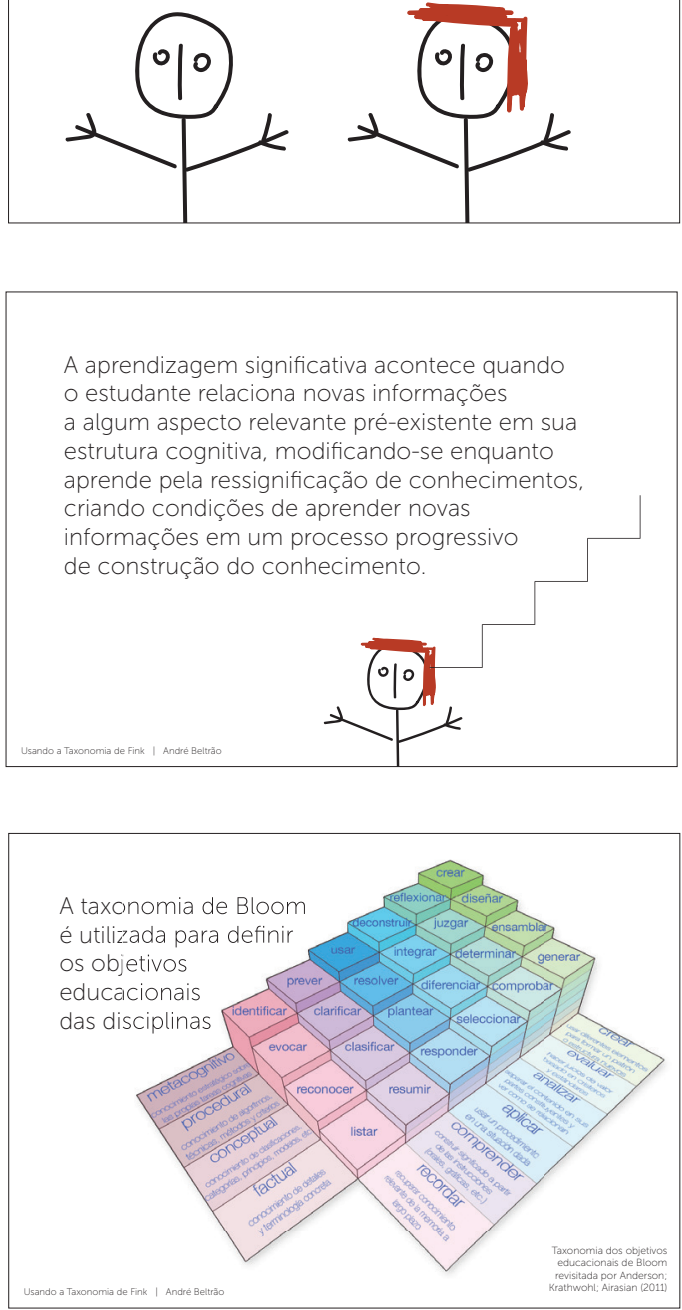

É preciso que o estudante encontre significado no que aprende.

A taxonomia

de Bloom

relaciona-se

a isso..

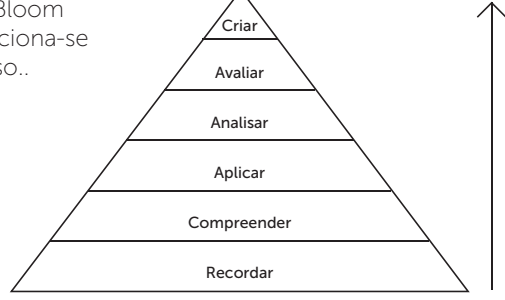

A aprendizagem significativa opõe-se

à tradicional aprendizagem mecânica, onde

os conceitos são mecanicamente decorados,

ou aplicados a situações genéricas, sem

significado para os estudantes.

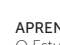

APRENDIZAGEM MECÂNICA

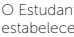

estabelecer $m$

outras informa
APRENDIZAGEM SIGNIFICATIVA a conhecimentos da estrutura 
Como a aprendizagem é um processo individual, devemos favorecer as condições para que os estudantes possam protagonizar seu processo de aprendizagem

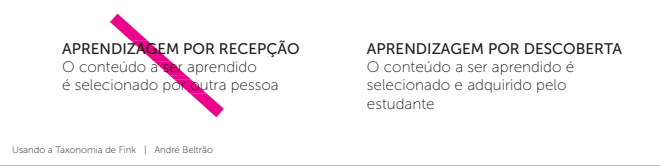

objetivo principal das Metodologias Ativas é viabilizar $\circ$ APRENDER A APRENDER. Algumas potencializam a construção dos conhecimentos básicos das disciplinas, outras relacionam-se à aplicação prática desses conhecimentos, ou integram diferentes saberes e criam valor para o conhecimento adquirido, fruto do esforço pessoal, e podem mudar opiniões e pontos de vista.

\section{Problematizar}

está relacionado aos Estudantes verem os problemas de forma mais completa, considerando a complexidade do mundo, e a buscarem soluções para a realidade em que vivem, tornando-se capazes de transformá-la pela própria ação,

ao mesmo tempo em que se transformam

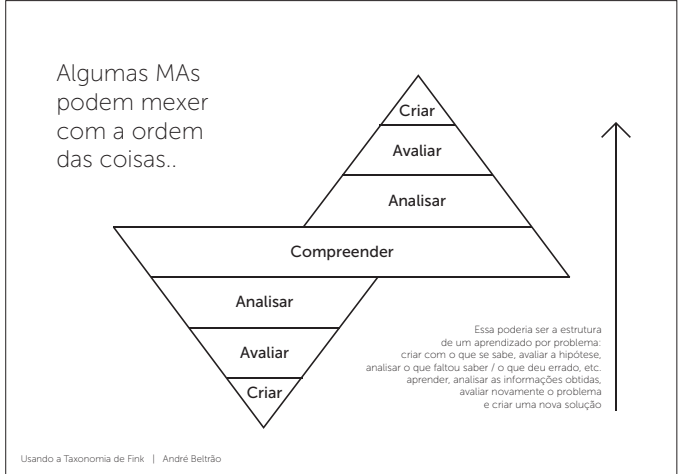

A grande questão ainda fica sendo: como cria significado para o estudante entrar em ação?

$$
\text { (ou. as aulas ativas }
$$

podem ser assim.

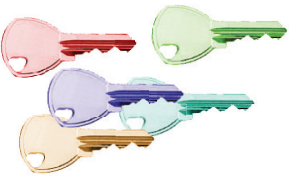

e a cabeça do
estudante assim

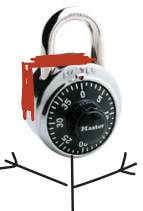

Enquanto o APRENDER está relacionado às metodologias mecânicas, e associado a copiar, memorizar, responder, resumir, reproduzir, fazer o que é solicitado,

o APRENDER A APRENDER envolve

argumentar, interpretar, ter autonomia, reescrever criticamente, elaborar textos próprios, propor e contrapropor

As Metodologias Ativas são metodologias de ensino comprometidas em ampliar as condições que favorecem

a aprendizagem do Estudante

Utilizam a problematização como estratégia de ensino-aprendizagem conectando o Estudante com o mundo e consigo mesmo

Metodologias ativas há muitas. Aprendizado baseado em problema. aprendizado baseado em projeto. Aprendizado baseado em grupos, Aprendizado por pares,

Aprendizado por desafio

Sala de aula invertida

etcetc

(não vou ficar explicando. senão a palestra fica muito monótona)

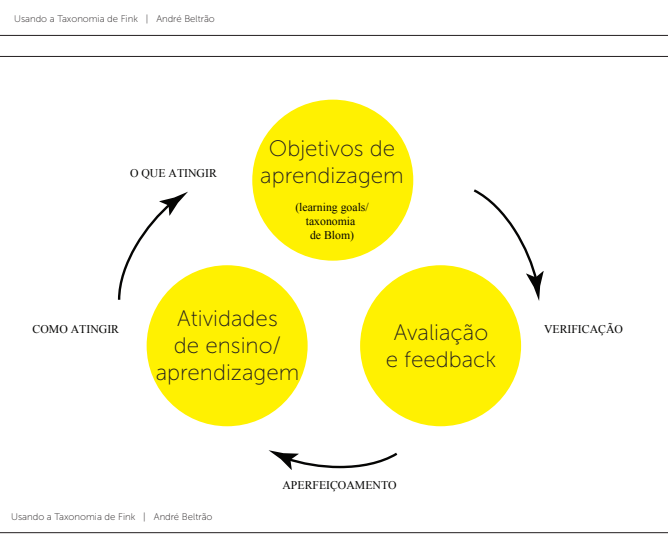

Nas primeiras décadas do século XX o educador norte-americano John Dewey defendia que o bom ensino deveria estimular a iniciativa apelando para as capacidades que o aluno já possuía, dando material novo para que ele pudesse reconstrui aquelas capacidades em um novo sentido.

A motivação para aprender, ou para empenhar-se ativamente nisso ou naquilo, segundo Dewey não pode ser simplesmente criada surge naturalmente quando se promovem condições propicias. 

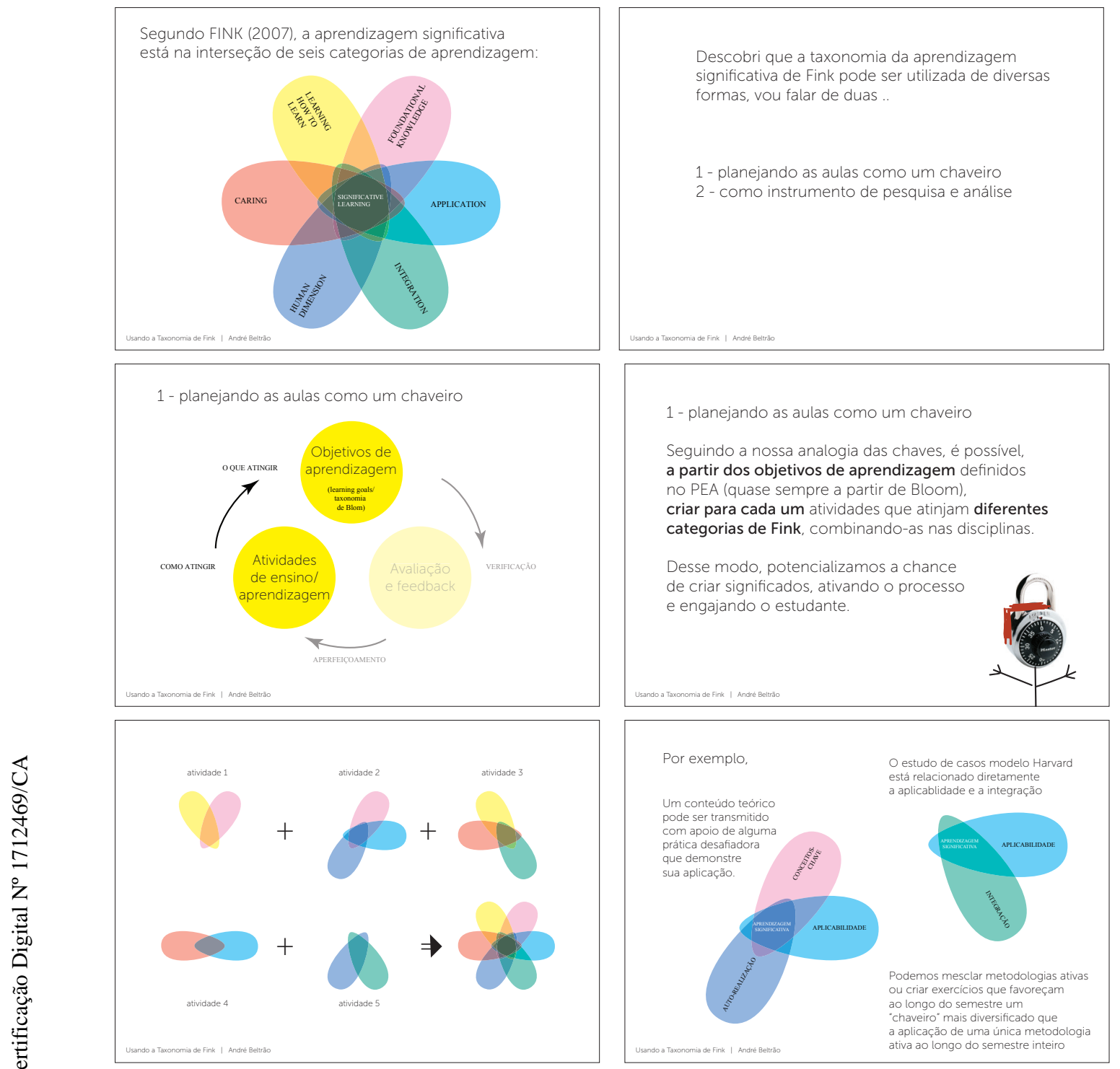

A medida que experimentava, vi que podia agrupar minhas práticas por finalidade (ativadores | incentivadores estruturadores | modeladores | desconstrutores)

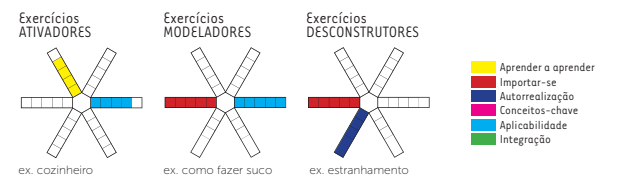

Cada professor pode criar seu "chaveiro" de práticas para serem escolhidas de acordo com a necessidade e aplicadas pontualmente nas disciplinas.

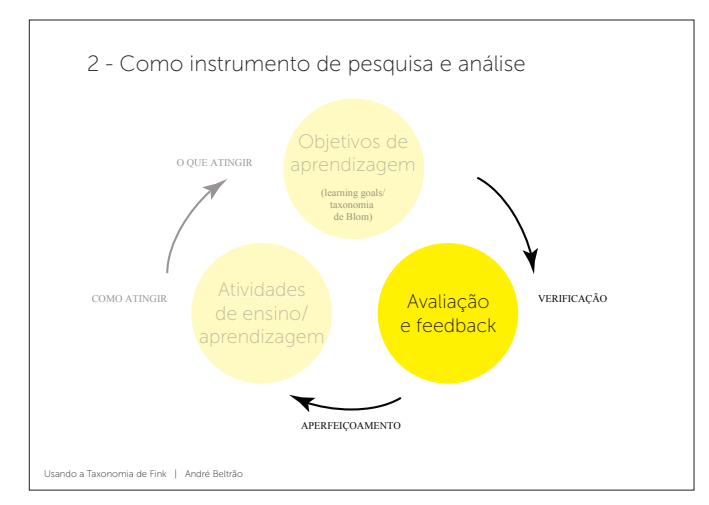

2 - Como instrumento de pesquisa e análise

Outra aplicação da taxonomia de Fink pode ser a de medir a percepção dos estudantes acerca de uma atividade ou mesmo de uma disciplina.

O professor pode, por exemplo, a partir de seu plano de ensino, imaginar no início do semestre o quão relevante sua disciplina deve ser em cada uma das categorias de Fink.

No final do semestre pode fazer uma pesquisa com os alunos e comparar os resultados às suas expectativas

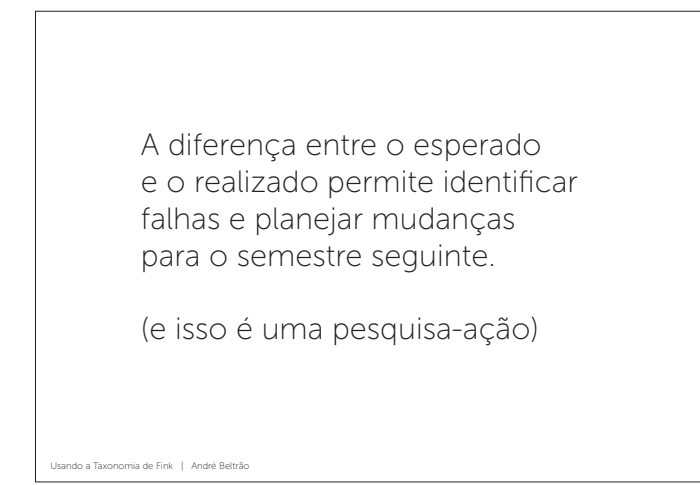



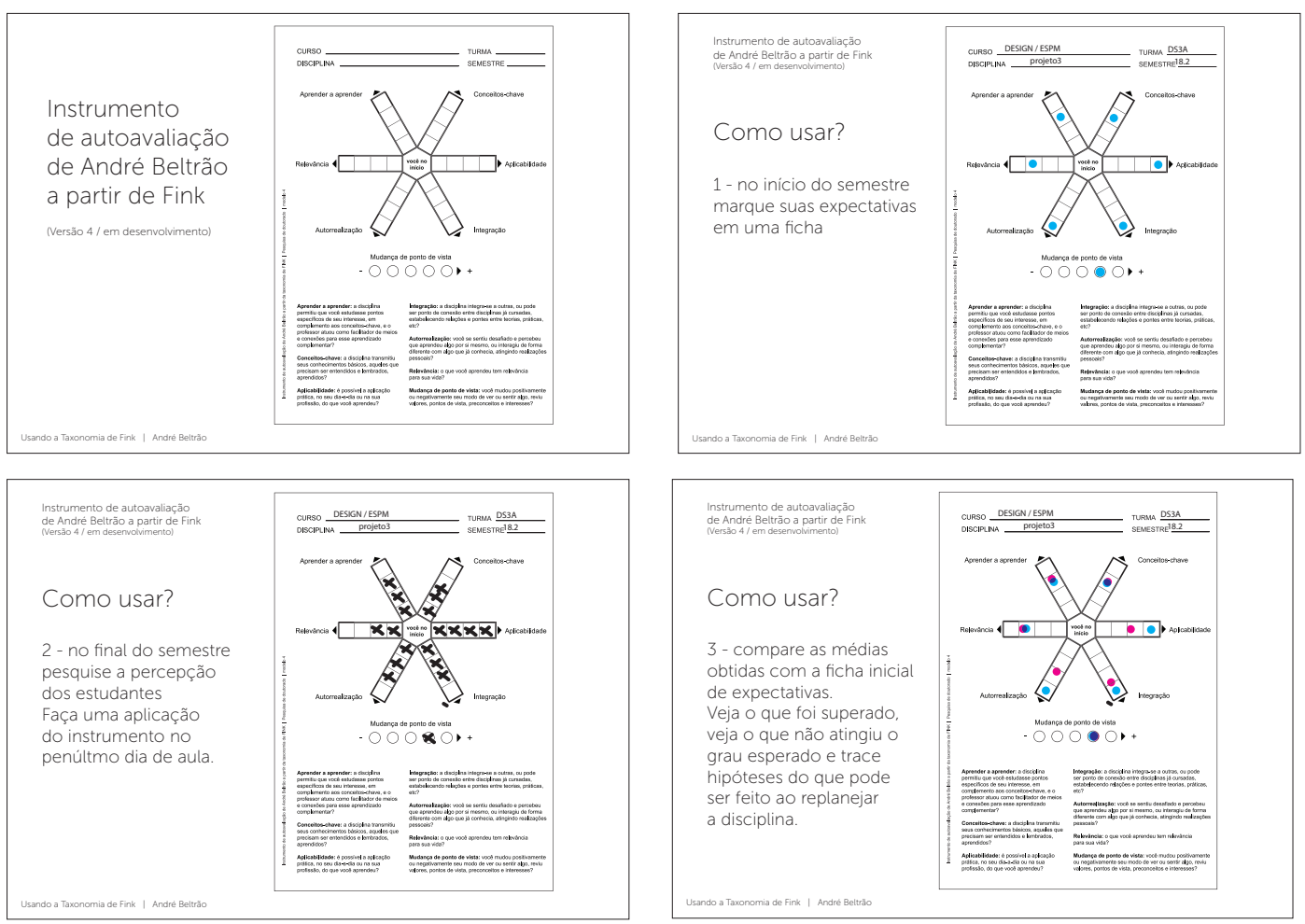

Convites aos professores:

1 - AGORA! Pensem em suas disciplinas e tentem imaginar como será a percepção dos ganhos obtidos pelos alunos no final do semestre.

No final do semestre, peça a eles para se autoavaliarem. Compare! Envie os resultados comentados para mim - faça parte da pesquisa!

Convites aos professores:

2 - Pensem em suas disciplinas e, a partir

dos objetivos de aprendizagem, pensem em um chaveiro de atividades utilizando diferentes categorias de aprendizagem significativa de Fink, sobretudo para pontos que considera críticos / dificeis. 